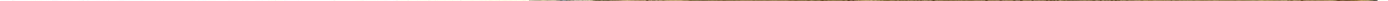




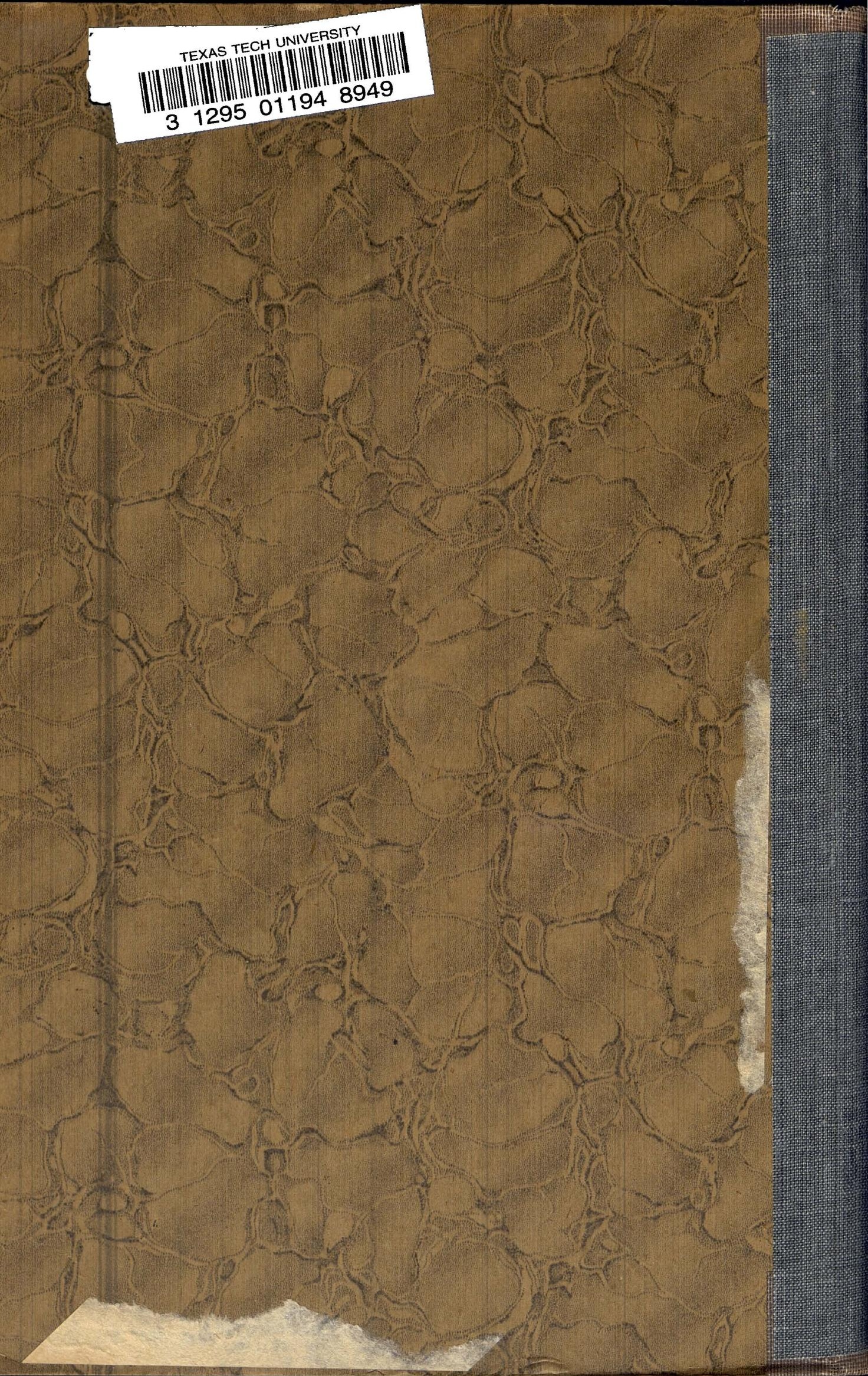


DEPARTMENT OF THE INTERIOR

UNITED STATES GEOLOGICAL SURVEY

CHARLES D. WALCOTT, DIRECTOR

\title{
SLATE DEPOSITS AND SLATE INDUSTRY OF THE UNITED STATES
}

BY

\author{
T. NELSON DALE \\ WITH SECTIONS BY
}

E. C. ECKEL, W. F. HILLEBRAND, AND A. T. COONS

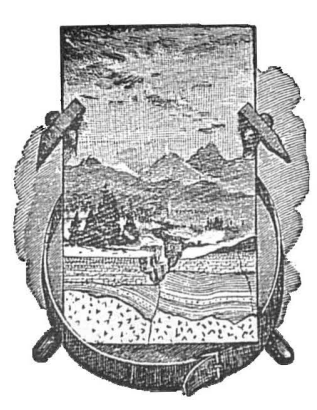

WASHINGTON

GOVERNMENT PRINTING OFFICE

1906 



\section{CON T ENTS.}

Page.

Definition and classification ................................... 5

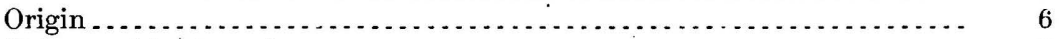

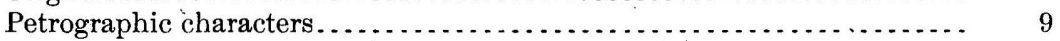

History of research $\ldots \ldots \ldots \ldots \ldots \ldots . . .69$

Spotted slates ............................................... 15

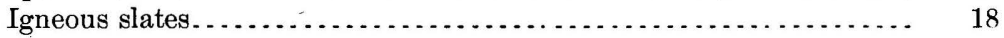

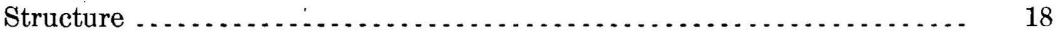

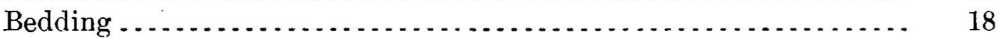

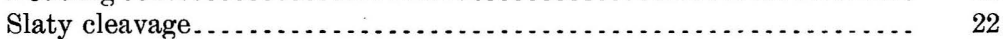

Slip cleavage ("false cleavage") $\ldots \ldots \ldots \ldots \ldots \ldots \ldots \ldots \ldots \ldots . . .24$

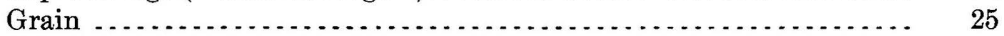

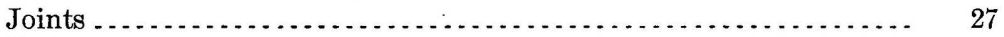

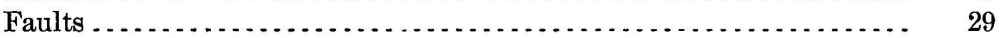

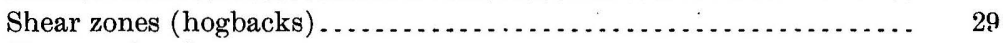

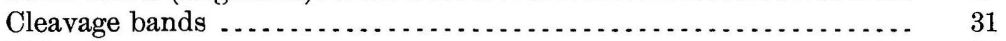

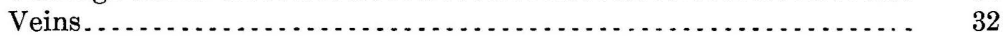

Nodules ................................................. 33

Dikes..................................................... 33

Geological relations. . . . . . . . . . .

Chemistry of slate .............................................. 34

Chemical composition .................................... 34

Chemical changes in weathering ........................... 37

Chemical composition of New York and Vermont slates........... 39

Economic geology of slate................................. 42

Difficulties in slate quarrying ................................ 42

Bedding and cleavage-how distinguished .................. 42

"Flints"--their nature and cause ........................... 43

Relations of joints, dikes, and shear zones................... 44

Use of geological map and compass in prospecting for slate......... 44

Methods of testing slate.................................. 45

Technical description of a slate quarry ...................... 50

Part II. Slate Deposits of the United States...................... 51

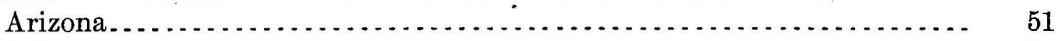

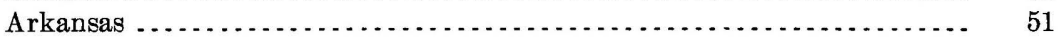

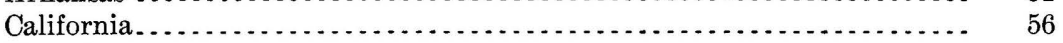

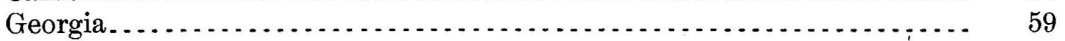

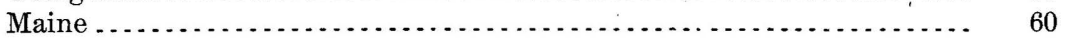

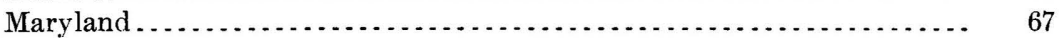

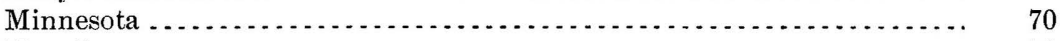

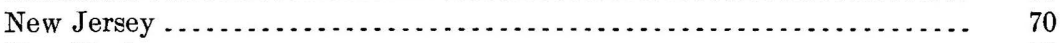

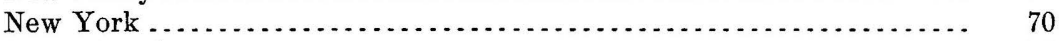

Pennsylvania ..................................................... 75

Pennsylvania and Maryland (Peach Bottom) $\ldots \ldots \ldots \ldots \ldots \ldots \ldots . . .65$

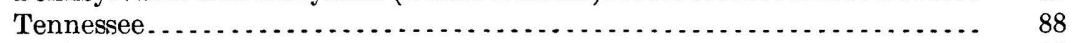

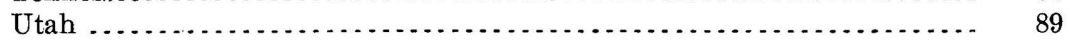

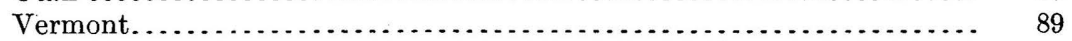

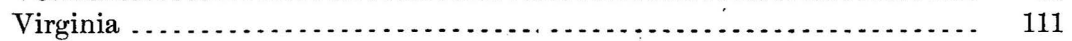

West Virginia ................................................ 119 
Part II. Slate Deposits of the United States-Continued.

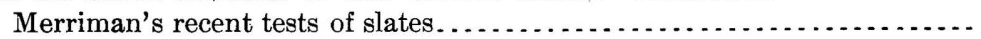

Comparative characteristics of slates . . ...........................

Statistics of production, imports, and exports......................

BibliogRA PHY

Glossary of Geological and Slate-QUarry Terms . . . . . . .

INDEX

Page.

122

124

125

138

146

149

\section{L L U STR A T I O N S.}

Plate I. Map showing location of slate deposits.......................

II. $A$, Red slate with bed of limestone and green slate; $B$, Bed of sandstone resting on slate ....................................

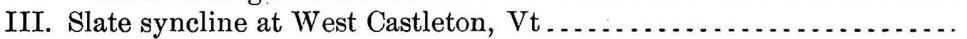

IV. Plicated and faulted beds in slate..........................

V. $A$, Quartzite beds in overturned folds in slate; $B$, Quartz veins in slate

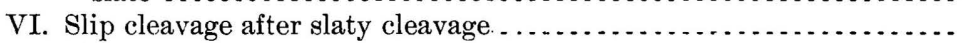

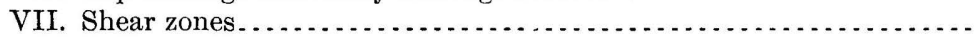

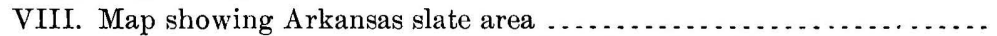

IX. Sketch map showing location of slate deposits of Montgomery-Polk

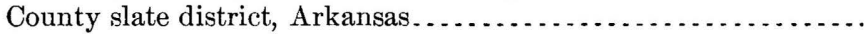

$\mathrm{X}$. Geologic map of the Placerville slate district, California ............

XI. $A$, Thin section of Brownville, Me., slate; $B$, Cleavage banding ....

XII. Merrill quarry at Brownville, Me..........................

XIII. Old Bangor quarry (north-northeast end), Pennsylvania...........

XIV. Old Bangor quarry (south-southwest end), Pennsylvania ..........

XV. Derricks and carriers, Old Bangor quarry, Pennsylvania ...........

XVI. Map of Slatington quarries, Pennsylvania .....................

XVII. Blue Mountain quarry, near Slatington, Pa . . . . . . . . . . . . . . . . .

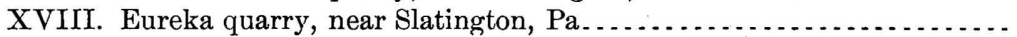

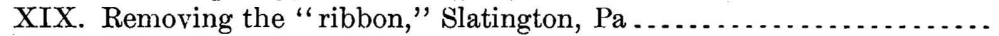

XX. Map of quarries in New York and Vermont slate belt, south part...

XXI. Map of quarries in New York and Vermont slate belt, north part...

XXII. Sections across New York and Vermont slate belt ................

XXIII. Quarry diagrams, New York and Vermont slate belt..............

XXIV. Quarry diagrams, New York and Vermont slate belt..............

XXV. Slate syncline at West Pawlet, Vt ............................

FIG. 1. Diagram, after Gosselet, showing relations of cleavage and bedding...

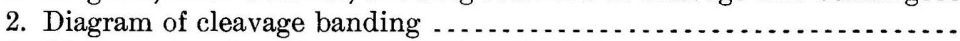

3. Diagram showing divergent strike of bedding and cleavage.........

4. Map of slate region in Maine...................................

5. Map of slate prospects in Frederick and Montgomery counties, Md ...

6. Sketch of anticline in Provident Slate Company's quarry, near Slatington, $\mathrm{Pa}$.

7. Sketch of anticline in old quarry north of Slatington, $\mathrm{Pa}$.

8. Sketch of syncline at William Hughes's quarry, Slatington, $\mathrm{Pa}$

9. Sketch of folds at Eureka quarry, near Slatington, $\mathrm{Pa} . . . . . . . . . .$.

10. Microscopic drawing of Peach Bottom slate ......................

11. Diagram showing structure at Vermont Black Slate Company's quarry, near Northfield, Vt.

Page.

\section{5}

12. Map of slate region in Buckingham and Fluvanna counties, Va.......

13. Map showing location of Snowden quarries, Amherst County, Va.....

14. Map of slate prospects in Fauquier County, Va................... 



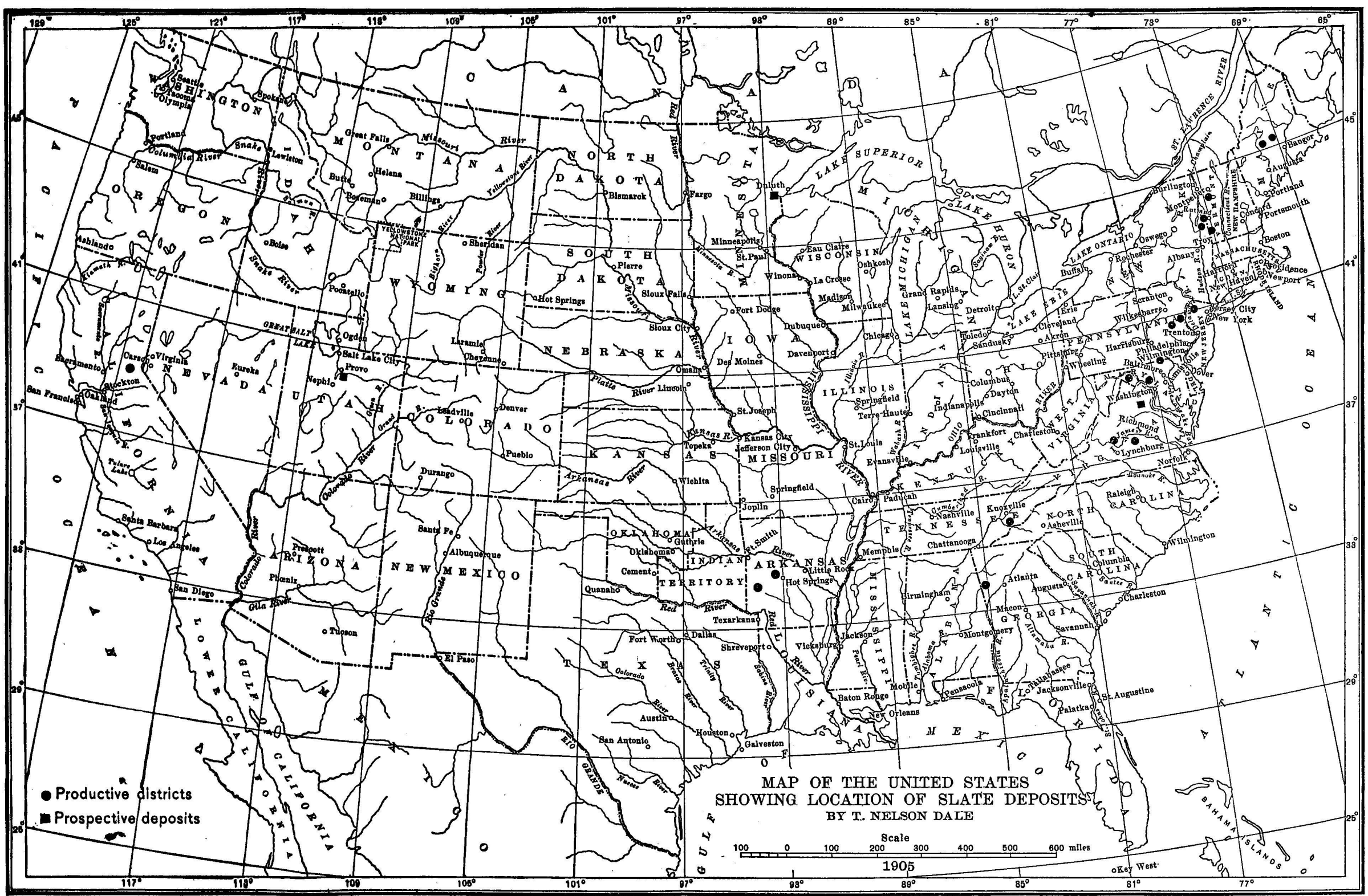




\title{
SLATE DEPOSITS AND SLATE INDUSTRY OF THE UNITED STATES.
}

\author{
By T. Nelson Dale and others.
}

\section{PART I.-ORTGIN, COMPOSTTION, AND STRUT́TURE OF SLATE.}

By T. Nelson Dale.

\section{DEFINITION AND CLASSIFICATION OF SLATE.}

Definition.-The term slate, in ordinary usage, denotes a rock which has more or less perfect cleavage, adapting it to various commercial uses, and in which the constituent particles, with very few exceptions, can not be distinguished except in thin section under a microscope. In contradistinction a schist is a rock of sometimes identical chemical and mineralogical composition, but is either made up of coarser particles or possesses a wayy structure, or else is marked by both of these features. Both slates and schists may have originated in deposits of identical character, but they have undergone different processes.

Slates as above defined vary greatly in color-from black through various shades of gray to greens, reds, and purples of different hues. They vary also in lusterfrom having none to being almost as bright as mica itself. They vary greatly not only in grade of fissility, but in surface texture, as seen by the unaided eye or determined by touch, and still more in microscopic texture, as seen in thin section. They differ also in mineralogical and chemical composition and in physical properties.

On account of their peculiar properties slates are adapted to a great variety of usesroofing, flooring, electric switch boarls, blackboards, hand slates, billiard and laboratory table tops, vats, mantels, grave linings, wainscoting, hearths, chimney and well caps, memorial tablets, bread boards, refrigerator shelves, etc. This stone has thus become linked with some of the principal necessaries of life and death.

Slates divide themselves naturally into (1) those derived from aqueous sediments and (2) those of igneous origin. The latter, however, are very exceptional. For commercial purposes the basis of classification of the aqueous sedimentary slates must be, first, structural, for the cost of their production and the degree of their strength depend primarily upon that; secondly, it must be mineralogical, for their durability depends upon their content of certain mineral constituents.

Those slates in which the particles have been merely compressed by weight or pressure and cemented by carbonates of lime and magnesia, by kaolin or different combinations of iron, and whose grade of fissility, strength, and elasticity are therefore low, must be distinguished from those in which, under metamorphic processes, the kaolin and feldspar have passed into mica, forming a more or less dense and regular crystalline fabric of overlapping scales and fibers inclosing any remaining sedimentary particles. Such slates necessarily possess a high grade of fissility and considerable strength and elasticity. The first group includes clay slates, the second mica slates or phyllite slates. Those in which the micaceous matrix is but partially formed, 
and which represent a transition from clay slate to mica slate, are more conveniently put into the clay-slate group. Thus the dark-purple ("red") roofing slate of Penrhyn, in .Wales, is a clay slate, and so also is the black slate of Martinsburg, W. Va.; but the French Ardennes slate, the Welsh Festiniog, and the Peach Bottom of Pennsylvania and Maryland, are all mica slate.

But mica slate includes slates of very different composition and structure, and therefore of properties and value. The first distinction to be made is based upon the amount of ferrous carbonate-whether or not it is sufficient to produce discoloration on continued exposure to the weather-for this is an important factor in the value of slates used for roofing. This distinction gives a group of fading and one of unfading slates, each of which can be further subdivided as to color. But each of these colors of fading and unfading mica slate embraces a wide range of texture. Some, like the Arkansas black and light-greenish slates, have a matrix of extremely fine sericite fibers, while the black slates of Arvonia, Va., and the Peach Bottom slates have a texture approaching that of a schist. Such differences in texture can not but result in difference of physical properties. The grades of texture are sufficiently designated by the words very fine, fine, medium, and coarse. There are also distinctions in the grade of fissility which do not always correspond to the grade of texture. These are conveniently numbered from 1 to 4 , beginning with those of the best fissility. Finally there are differences in luster and amount of magnetitedifferences which are purely specific. The general distinctions are formulated in the following table:

(I) Aqueous sedimentary.

Classirication OF SLATE.

(A) Clay slates: Matrix without any or with but very faint aggregate polarization.

(B) Mica slates: Matrix with marked aggregate polarization.

(1) Fading: With sufficient $\mathrm{FeCO}_{3}$ to discolor considerably on prolonged exposure.

(a) Carbonaceous or graphitic.

(b) Chloritic (greenish).

(c) Hematitic and chloritic (purplish).

(2) Unfading: Without sufficient $\mathrm{FeCO}_{3}$ to produce any but very slight discoloration on prolonged exposure.

(a) Graphitic.

(b) Hematitic (reddish).

(c) Chloritic (greenish).

(d) Hematitic and chloritic (purplish).

(II) Igneous.
(A) Ash slates.
(B) Dike slates.

The scientific basis for these subdivisions will be seen by consulting the table facing page 124 and the microscopic and chemical analyses of the slates there named. The application of this scheme to 13 kinds of American slates will be found on page 125 .

\section{ORIGIN OF SLATE.}

With the exception of the rare slates of igneous origin, referred to in the previous section, slates originate in marine deposits of clay and sand. The common occurrence of angular grains of feldspar and of quartz in slate implies the nearness of shores or land masses of granitic rocks to such deposits. The alternation of beds of slate with beds of quartzite or grit ("ribbons," "hards," altered sandstone) corresponds to the alternation of extremely fine clayey sediments, derived from the waste of granitic land masses, with sandy sediments consisting of coarser material from 
the same source. The repeated alternation of such fine and coarse sediments is attributed to the alternation of calm water, favorable to the deposition of fine material, with strong currents that bring coarse sediments more rapidly from the shore. These materials consisted largely of quartz, feldspar, and mica, but included also zircon and other silicates, various compounds of iron, lime, and magnesia, as well as kaolin arising from the decomposition of the feldspar. In such a slate region as that of western Vermont and eastern New York, where the slate is interbedded with fossiliferous limestone, it is evident that alternating with such changing conditions in the water there were also periods when marine life abounded and the sediments were entirely calcareous. Black slates owe their blackness to carbonaceous matter, probably derived from the decomposition of marine organisms on the sea floor. Red slates owe their color to the access of ferruginous matter from the land, and purplish ones to an admixture of this and a green magnesian mineral (chlorite) of secondary origin. In both the reddish and purplish slates the iron is supposed to have been originally precipitated in the form of the rust-colored limonite $\left(2 \mathrm{Fe}_{2} \mathrm{O}_{3}, 3 \mathrm{H}_{2} \mathrm{O}\right)$ from iron-bearing solutions, and afterwards altered by loss of water $\left(\mathrm{H}_{2} \mathrm{O}\right)$ to the reddish hematite $\left(\mathrm{Fe}_{2} \mathrm{O}_{3}\right)$. $a$.

An accumulation of several hundred feet of such clayey and sandy sediments when buried under several thousand more of other sediments of like origin on a gradually subsiding sea bottom must have been subjected to sufficient vertical pressure, in connection with a small amount of moisture, to have been cemented together and hardened-the clay into shale and the sand into sandstone. During this process the particles in these sediments retained the general horizontal and parallel arrangement which they had received from their distribution by sea water, but became firmly compacted and thus acquired a bedding foliation.

The next stage in the formation of slate is attributed ultimately to the radiation of heat from the earth's interior into space, resulting in a contraction of the interior, and consequently in a corrugation of the upper portion. This corrugation, for reasons not yet perfectly evident, took place, as far as observation extends, chiefly within certain belts along the axes of our mountain systems, producing lateral compression in a great mass of parallel strata. The first effect of this compression was to bend at least the lower portion of the strata into wave-like folds, and thus to shorten its horizontal area in one direction and increase its vertical thickness. The character of this folding is well shown in the Pennsylvania and western Vermont slate regions (see Pls. III, XIII, XIV, XVII, XVIII, XXII, XXV). But another effect of this compression was to metamorphose the shale into slate. This metamorphism probably did not take place until the folding was well initiated. The transformation included two processes, and it is uncertain which preceded. There was a rotation of each individual sedimentary particle from its original horizontal position in the bedding foliation into one forming a considerable angle to the direction of pressure. There was also, under the combined presence of moisture and the effect of pressure and heat, both that which must have been generated by the pressure and that which pervaded the strata at the depth at which they were buried, such a chemical recombination of the silica, alumina, potash, iron, and water of the feldspar, kaolin, and iron of the shale as to generate new potash-mica in amount sufficient to constitute, in the case of the mica-slates, over 33 per cent of the resulting slate. This muscovite was formed in scales of infinitesimal thinness and other dimensions, and generally of longish, tapering, or ribbon-like outline. Most of these scales arranged themselves with their flat sides parallel to or overlapping one another, but facing the direction from which the pressure came, and also with an angle of inclination governed by that pressure. A small but variable proportion, however, of these

$a$ See on these changes Van Hise, C, R A treatise on metamorphism: Mon. U. S. Geol. Survey, vol. 47 , pp. 225,232 . 
scales took such a position that their flat sides became parallel to the direction of the pressure, and the longer axes of the other scales also lay in that direction. As mica crystallizes in columnar crystals, and as the plates or scales due to its molecular structure are transverse to the crystal column, and as a slab of slate consists largely of parallel scales of mica it may be said to correspond when held horizontally to such a crystal held vertically. When a mica-slate is cut in thin section across the cleavage its optical behavior under polarized light is like that of a mica crystal cut across its crystal cleavage. Yet as not only a considerable number of the mica scales in slate lie across the cleavage, but as some scales of chlorite and crystals of other minerals do also, the texture of a mica-slate combines some of the features of a crystal with some of those of a tissue. Extremely thin sections of slate transverse to the cleavage sometimes show this interlacing of the two sets of scales on their attenuated edges. It is to this microscopic texture that slate largely owes its peculiar properties.

This crystalline fabric may inclose in its meshes any sedimentary particles of quartz, zircon, feldspar, kaolin, or other minerals which were not or could not be made over into mica or secondary quartz, but whose alignment became more or less parallel to that of the major part of the new mica. During this metamorphism other chemical combinations arose from the constituents of the shale. These crystallized in isolatedscales or crystals of chlorite, biotite (magnesia mica), various carbonates, pyrite, magnetite, graphite, tourmaline, andalusite, etc. These arranged themselves variouslysome in the cleavage direction, some in the grain direction. Various lenses, consisting of one mineral surrounded by one or two others, were also formed and arranged. The limonite became hematite. And during these changes in the fine sediments the intercalated beds of sandstone passed into quartzite and metamorphic grit by the formation of siliceous and micaceous cement between their particles.

The essential part of the process of the transformation of a granitic rock into clay and of that into mica may be made generally intelligible by recalling two well-known experiments of Daubrée, the French experimental geologist. In the first, angular fragments of granite and quartz were rapidly rotated in a horizontal iron cylinder filled with water and moving on an axis. The trituration resulted in producing a very fine clay. The second consisted in inclosing clay and water in a closed wroughtiron tube, which was then placed in a gas furnace and exposed for several weeks to a very high temperature. The result was the production of scales of mica. In the first experiment the factors of stream and wave erosion were duplicated, and in the second the elements of moisture, pressure, and heat involved in the crystallization of new minerals from clay were reproduced.

Two other experiments illustrating the arrangement of the mica thus formed, as well as the sedimentary mica and other minerals, may well be cited here, also. The familiar one of Tyndall, which consisted in subjecting wax to pressure between glass plates and, after cooling it in ice and salt, breaking it edgewise with a hammer. The fractures showed that it had acquired slaty cleavage. The other experiment was made by Jannetaz, and consisted in subjecting a mass of clay in a wrought-iron box, open at one side, to hydraulic pressure, which resulted in the formation not only of slaty cleavage but also of the grain structure.

The general microscopic structure of slate is such as to warrant the assumption that the compression which produced it operated not only with great uniformity but also very gradually.

The microscopic features of slate will be found more fully considered in the following section on the petrographic characters of slate. The above will suffice, however, to convey, with as few technical terms as possible, a general idea of the principal steps in the formation of a mica-slate of aqueous-sedimentary origin. The history of clayslate is similar, but metamorphism has been insufficient to produce the micaceous texture in it. After the slate was formed the mass was subjected to various stresses 
(tensions, shears, contractions), which resulted in several systems of joints, in faults, slip cleavage ("false cleavage"), shear zones ("hogbacks"), and in irregular openings in which veins of quartz and calcite were formed by infiltration; and the mass, in some cases, was traversed by fissures penetrating to the molten zone and thus permitting the exudation of lava-like material which formed dikes.

The folds into which the slate beds were bent are rarely complete, for the reason that their upper portions have generally been removed through various erosive processes - the decomposition due to atmospheric agencies, the action of streams, and, in places, of the continental glacier. Pls. III, XIII, XIV, XVII, XVIII, and $\mathrm{XXV}$ all illustrate this feature. In the Appalachian region generally the thickness of this eroded material was very considerable.

\section{PETROGRAPHIC CHARACTERS. $a$}

\section{HISTORY OF RESEARCH.}

However uncertain the structural, mineralogical, and chemical features of roofing slates may once have seemed, these are all now well understood. Sedgwick, Sorby, Phillips, Tyndall, Daubrée, Gosselet, Jannetaz, and Becker have studied their structure either in the field or the laboratory, or in both, and Sorby, Zirkel, Renard, and others have investigated their mineralogical composition. Summaries on the cleavage of slate were published by Loretz in 1880, and Harker in 1886, and on 'its petrography by Kalkowsky in 1886, Zirkel in 1894, and Rosenbusch in 1898. Chemical analyses are given in Roth's Chemical Geology (1890), and in Zirkel's Petrography (1894). Hillebrand, Reade, and Holland made a number of complete analyses between 1899 and 1901. Van Hise, in his recent Treatise on Metamorphism $b$ (1904), discusses the theory of metamorphism in schists and slates, and Leith, in his paper on rock cleavage ${ }^{c}$ (1905), treats of the theory of bedding and cleavage, basing his conclusions more largely on the microscopic study of schists than of roofing slates. The bibliography on pages 138-145 shows how much has been written on the different aspects of the subject. It is not proposed to give here a summary of all this literature, but an attempt will be made to set forth, in a series of statements, quotations, and questions, the state of scientific opinion on the more important and interesting features of slate.

Slaty cleavage may be defined simply as a rearrangement of the particles of a deposit by lateral pressure, together with the arrangement of any new crystalline particles formed during and in consequence of that pressure. This arrangement of old and new particles is related to the directions of pressure and resistance. The older authorities on slaty cleavage usually define the direction of pressure as being at $90^{\circ}$ to the cleavage. This definition of the direction has, however, been under discussion in recent years. The latest phase of opinion appears in the writings of Van Hise, Becker, and Leith. Van Hise ${ }^{d}$ expresses his views in these words:

During the process of recrystallization at any given moment there is maximum shortening in the direction of greatest stress, maximum elongation in the direction of least stress, and shortening or elongation in the direction of mean stress. Consequently the shape of the modified particle may be that which would be produced if a plastic grain were rolled out, the sides being confined in one direction, but with liberty to elongate in another direction in the same plane; or it may be that which would be produced if a roundish cake of dough were flattened between two boards, and consequently elongated in all directions at right angles to the direction of greatest pressure. . . . The particles are arranged with their greater, mean, and minor diameters, corresponding to least, mean, and greatest pressures. In proportion as the movement involves shearing motion or seission the mineral particles are rotated from a position in which the direction of greatest elongation is at right angles to the direction of greatest pressure, although at any given time the mineral particles tend to develop with their longer axes at right angles to the maximum pressure.

$x$ This chapter in its original form appeared in part 3 of Nineteenth Ann. Rept. U. S. Geol. Survey, in 1899 , but its matter is here revised and brought up to date.

$\checkmark$ Mon. U. S. Geol. Survey, vol. 47.

$c$ Bull. U. S. Geol. Survey No. 239 .

$d$ Treatise on metamorphism: Mon. U. S. Geol. Survey, vol. 47, 1904, pp. 752, 753. 
Becker's experimental studies were directed to determining the mathematical character of the deformation undergone by a plastic but crystalline mass under pressure. For this purpose he pierced a block of ceresin with needle holes at regular intervals in both a vertical and a horizontal direction, drawing a thread smeared with coloring matter after the needle, and subjected the block to powerful vertical pressure. The curves then assumed by the colored lines enabled him to determine the position of the axes of the strain ellipsoid with relation to the direction of pressure. The result of this and of other experiments described in the same paper is that-

cleavage does not coincide even approximately with the direction of the major axes of the strain ellipsoid. Neither does the cleavage correspond to the position of the major axes of the strain ellipsoids at any previous stage of the strain. $a$

In other words, slaty cleavage is not perpendicular to the smallest axis of the strain ellipsoid, but makes with "that axis an acute angle equal or greater than $45^{\circ}$ and increasing as the strain grows greater." Both the experiments and the reasoning seem simple and clear.

Leith, following Van Hise, states that-

Cleavage is always tending to develop normal to the greatest principal stress, but its final position may or may not be inclined to the greater stress, depending upon the nature of the strain. $b$

This question of the relation of the dip of slaty cleavage to the direction of pressure is not a purely speculative one, but bears directly upon problems in field geologý. Thus where cleavage is nearly horizontal it is probable that a secondary crustal movement must have diminished the original inclination of the cleavage, and consequently the whole attitude of the folds. Were the limiting angle at which slaty cleavage forms established, then, in the case stated, a maximum figure for the angular displacement of the cleavage could be obtained.

There is some vagueness in scientific literature, as well as in popular conception, as to what constitutes a slate. Sorby drew this distinction:

When a section [of a fine-grained slate] cut at right angles to the cleavage is rotated in polarized light it becomes, over nearly the whole surface, very bright, and much darker at different azimuths, like a doubly refracting crystal, whereas there is little or no such change in the case of true clay slates of the normal granular type containing much kaolin and very little mica. $c$

Micaceous luster is not a satisfactory criterion, for some slates, like those from Monson, in Maine, are almost lusterless and yet possess a brilliant aggregate polarization and are very sonorous. They are mica-slates (phyllite-slates), as are the Brownville slates, from the same State, which have a micaceous luster.

An interesting transition from a shale to a mica-slate, described on page 81 , occurs at Lehigh Gap, Pennsylvania. The new muscovite (sericite) has begun to form across the bedding of the shale without as yet any change of orientation in the clastic particles. In a specimen of shale from Rensselaer County, N. Y., $d$ the incipient alignment of clastic muscovite across the bedding is well shown in thin section, and slip cleavage seems about to be set up. Some specimens of clay-slate from Martinsburg, W. Va., show a slaty cleavage without any matrix of muscovite whatever, but others show the beginning of one by a faint aggregate polarization. These cases suffice to show that all transitions from a shale to a clay-slate and to a mica-slate occur.

While it is supposed that mica-slate is the product of a less intense metamorphism than schist $e$-and it is also assumed that the process by which slaty cleavage was produced was marked by great uniformity, and also took place slowly-there are as yet neither observations nor experiments for a perfectly satisfactory reply to the fol-

a Experiments on schistosity and slaty cleavage: Bull. U. S. Geol. Survey No. 241, 1904, p. 21. $b$ Rock cleavage: Bull. U. S. Geol. Survey No. 239, 1905, p. 138.

$c$ On the structure and origin of noncalcareous stratified rocks: Quart. Jour. Geol. Soc. London, vol. 36, p. 76.

$d$ See Bull. U. S. Geol. Survey No. 242 , Pl. II, $B$.

$e$ Van Hise, op. cit., p. 894: "When the depth is not great and the mass-mechanical action is not very severe, slates are likely to form. When the depth is greater and the mass-mechanical action is severe, schists or gneisses are likely to develop." 
lowing questions: Why should one part of a sedimentary formation have been altered into roofing slate and an adjacent part of the same into schist? Would continued metamorphism transform a roofing slate into a schist? Were schists of sedimentary origin at one stage roofing slate? Why should metamorphism begin in some shales by the formation of slip cleavage leading to schist, and in others by slaty cleavage?

As to the mineral constituents of slate, Sorby gives the average size of the scales of sericite $a$ in the best Welsh slates as one two-thousandths of an inch in breadth by one six-thousandth in thickness. $b$ Scattered about among the meshes of the muscovite are minerals which extinguish irregularly. Chief among these is quartz, mostly in clastic grains, sometimes formed in situ or in lenses of chalcedony. This secondary quartz may attach itself to the quartz fragments or to the various other minerals to be named. Next in importance is a chloritic mineral, dichroic (light yellow, dark green), polarizing from a Prussian or plum blue to a violet or olive when the section is tra.2sverse to the scale, but remaining dark between crossed nichols during a complete revolution when the section is parallel to it. These scales are usually intergrown with lamellæ of muscovite, sometimes of biotite, and lie-some transverse to the cleavage and parallel to the grain, others parallel to the cleavage. $c$ Chlorite and quartz sometimes make up minute lenses with their long axes parallel to the cleavage, or chlorite surrounded by sericite makes lenses with their long axes in the grain direction. These scales of chlorite sometimes contain needle-like crystals, probably rutile, crossing one another at angles of $60^{\circ}$ and $120^{\circ}$ (see p. 80). This chloritic mineral is regarded as of secondary origin. Rutile needles are generally, but not always, present, and in great abundance. $l$ This mineral occurs also in irregular masses up to $0.05 \mathrm{~mm}$. in diameter, consisting of a network of prisms forming angles of $60^{\circ}$ and $120^{\circ}$ (sagenite twins). Thus at Bremo, Va., as stated on page 115 , hematite occurs in very minute scales and dots and very abundantly in the reddish and purplish slates. $e$

There are also cubes, lenses, and spherules of pyrite. The spherules abound in black slates. Carbonaceous matter and graphite abound in the black and dark-gray slates. Clastic grains of feldspar and of zircon are characteristic. Hemimorphic prisms of tourmaline are not very unusual.

Calcite and other carbonates, particularly one of lime, iron, and magnesia, are apt to be evenly disseminated in rhombs and plates. Rhodochrosite $\left(\mathrm{MnCO}_{3}\right)$ probably also occurs (see p. 71). The following have also been identified: Ottrelite, staurolite, garnet, andalusite, sphene, anatase, biotite, hornblende, epidote, apatite, pyrrhotite, gypsum, magnetite, limonite, pyrophyllite, talc.

Slates are often speckled with minute protuberances which under the microscope resolve themselves into the lenses just referred to-so-called "eyes" or "knots." Instead of consisting of chlorite and quartz, they may consist of an octahedron of magnetite partially surrounded by quartz and that entirely by chlorite. $f$ This quartz is then regarded as a later infiltration into a cavity formed between the magnetite

\footnotetext{
$a$ See Laspeyres, Sericit: Zeitschr. für Kryst., vol. 4, 1880, p. 224.

$b$ Sorby, ibid.

c See Renard, Recherches sur la composition et la structure des phyllades ardennais: Bull. Mus. roy. d'hist, nat. de Belgique, vol. 3, p. 235, pl. 12; Zirkel, Lehrb., 1894, p. 298; and G. Rose, Über die regelmässige Verwachsung der verschiedenen Glimmerarten mit einander sowie mit Pennin und Eisenglanz: Monatsber. K. Akad. zu Berlin, 1869.

d On these see Zirkel, Ueber die mikroskopische Zusammensetzung yon Thonschiefern und Dachschiefern: Poggendorft Annalen, vol. 144, 1891, p. 319; Van Werweke, N. Jahrb. Min. Geol., 1881, vol. 1, p. 178; Sauer, N. Jahrb. Min. Geol., 1881, vol, 1, p. 227-238; Cathrein, Ueber das Vorkommen mikroskopischer Zirkone u. Titan-Mineralien in den Gesteinen, Würzburg, 1884; Kulkowsky, Elemente der Lithologie, 1886, p. 257. Sorby (loc. cit., p. 68) gives the diameter of the slate needles as less

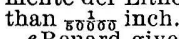

$e$ Renard gives the size of the granules of $\mathrm{Fe}_{2} \mathrm{O}_{3}$ as $0.020-0.005 \mathrm{~mm}$; op. cit., vol., 3, p. 234 . See also his Pl. XII, fig. 2, of purple and green slate, in same volume. See also Gosselet (Etudes sur l'origine de l'ottrelite: Ann. Soc. Géol. du Nord, vol. 15, 1887-1888, Lille, 1888, pp. 188-189) who describes hematite as occurring in three forms in the reddish slates: (1) In irregular grains 0.01 to $0.02 \mathrm{~mm}$. or less; (2) in scales with a bluish steel-like luster under a mixture of reflected and transmitted light; (3) in minute granules which are always red, a brick-red under reflected light.

$f$ See Geinitz, Der Phyllit von Rimogne in der Ardennen: Tschermaks Min. Mittheil. (new folge), vol. 3; also Renard, op. cit., vol. 2, 1883, p. 133 et seq., and pi. 6.
} 
and the chlorite by pressure. Others consist of chlorite surrounded by calcite and that by quartz. $a$

Others have a central crystal of pyrite instead of magnetite, $b$ or the pyrite may have been changed to limonite. $c$ Still others consist of chalcedony surrounded by chlorite scales, $d$ or of quartz surrounded by radial plates of muscovite, $e$ or of biotite surrounded by quartz (see p. 65). These lenses may, as in the Peach Bottom slates (see p. 87), be so minute as not to result in any visible speckling of the surface, and may consist of crystals of andalusite surrounded by chlorite, quartz, or muscovite, the orientation of the lens being different from that of the crystal. These crystals of andalusite may have quartz on one side and muscovite on the other.

Finally, the discoloration once attributed by Bischof to the hydration and oxydation 'of a ferrous oxide has been shown, in some slates at least, to be due to the alteration of a ferrous carbonate to limonite, and is thought to be probably due to this in most slates (see pp. 36,39 ).

The presence of kaolin is, of course, to be assumed in all clay-slates and also in all mica-slates in which the micatization of the matrix is incomplete. Its presence in minute quantities in those mica-slates which have little or no luster, like the Monson, Me., slates, and possibly the Lehigh and Northampton County slates of Pennsylvania, may be suspected, but not demonstrated.

Leaving out the rarer and less significant constituents and basing his estimates on the chemical and microscopic analyses of the principal varieties of slate from the French Ardennes, Renard computes the mineral percentages as follows:

Percentages of minerals in slates of Ardennes, France.

\begin{tabular}{|c|c|c|c|c|}
\hline Mineral. & Purple. & Green. & $\begin{array}{l}\text { Bluish } \\
\text { black. }\end{array}$ & $\begin{array}{l}\text { Grayish } \\
\text { green. }\end{array}$ \\
\hline Muscovite (sericite) ....... & 40.69 & 39.54 & 37.75 & 37.97 \\
\hline Chlorite................... & 7.75 & 5.81 & 12.55 & 17.99 \\
\hline Quartz .................. & 40.41 & 45.78 & 40.58 & 30.97 \\
\hline 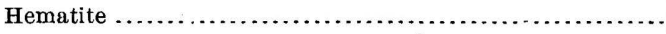 & 6.23 & 2. 90 & 4. 81 & $\therefore \ldots$ \\
\hline 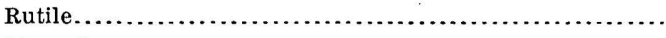 & 1.55 & 1.04 & & 1.34 \\
\hline Limonite..................................... & .......... & ........... & .... & 3.09 \\
\hline
\end{tabular}

In round numbers this amounts to-

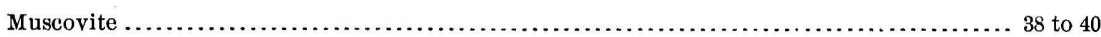

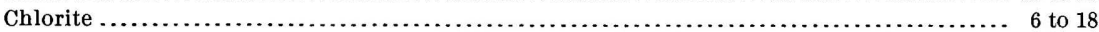

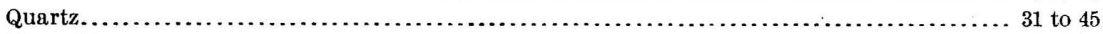

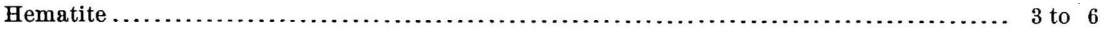

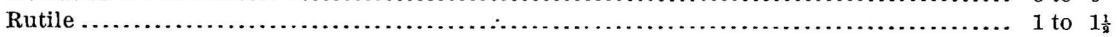

Renard $f$ calls attention to the fact that the green slates of Fumay in the Ardennes contain 4 per cent more $\mathrm{SiO}_{2}$ than the purple ones and about $3 \frac{1}{2}$ per cent less $\mathrm{Fe}_{2} \mathrm{O}_{3}$.

Rosenbusch, $I$ in comparing 18 analyses of clay slates from different parts of Europe, calls attention to the strikingly characteristic preponderance of the $\mathrm{MgO}$ as compared with the $\mathrm{CaO}$, along with a uniformly high percentage of iron oxides and of $\mathrm{Al}_{2} \mathrm{O}_{3}$, and also to the like preponderance of the $\mathrm{K}_{2} \mathrm{O}$ over the $\mathrm{Na}_{2} \mathrm{O}$, which he explains thus:

Clays and clay slates constitute the finest mechanical detritus from quartz feldspar rocks; whatever silicates of lime they contain was removed as a soluble bicarbonate and for this reason very little lime-soda feldspar can occur in such a detritus.

$a$ Renard, op. cit., p. 248.

bSee Harker, on "eyes" of pyrite and other minerals in slate; Geol. Mag., Dec. III, vol. 6, No. 103,

p. 396 . London, Sept., 1889 .
$c$ Loretz, Ueber Transversalschieferung, etc., 1882, pp. 283-289. (For full titles of papers and works cited see Bibliography, pp. 138-145.)

a Mallard, Sur l'examen microscopique de quelques schistes ardoisiers: Bull. Soc. minéralogique de France, vol. 3, No. 4, 1880, p. 101.

e Zirkel, Lehrb., p. 744, Thonschiefer

$f$ Op. cit., vol. 2, 1883, p. 147.

$g$ Elemente der Gesteinslehre, p. 424 . 
While there has been substantial agreement as to the general microscopic and chemical character of roofing slates, there have been questions as to the origin of some of their constituents. Is the muscovite (sericite) which makes up from a third to a half of the mica-slates the product of the metamorphism of argillaceous material, or are these shred-like scales the result of the disintegration of some micaceous rock, the effect of pressure having been simply to bring the shreds into parallelism and to mat them together? A shale under the microscope shows a considerable amount of apparantly clastic muscovite in scales of various sizes with more or less arrangement in the direction of the bedding. Sorby regarded the micaceous mineral of slates as formed in situ by an alteration of partially decomposed feldspar, yet admitted that the structure was just such as would result from the deposition of material sorted by gentle currents and subsequently compressed, but the chlorite he considered as undoubtedly secondary. $a$

Rosenbusch wrote:

Of course the material of clay slates was mechanically brought together, but the mineral constituent of that part which is mainly micaceous and without feldspar was certainly the result of metamorphic processes which were intimately connected with dynamic-geologic processes. $b$

Hutchins expressed his conclusions thus:

This fine mixture of biotite, muscovite, kaolin, the minutest waste of feldspar, and in less degree of quartz, and probably other substances, under the joint action of pressure, warmth, and mineral solutions, gives rise to various decompositions and recombinations which result, among other things, in the formation of new mica, with the separation of titanic acid in the form of rutile. Into these reactions, whatever may be their exact course, even the muscovite in very fine state of division appears to enter: and there is good reason to conclude that in fine-grained sediments of suitable composition, exposed long enough to the necessary conditions as to pressure, temperature, and percolation of solutions, an almost complete regeneration of the "paste" to mica can and does take place, and that this regenerated material, under intenser dynamo-metamorphic action, is converted into some of the forms of micaceous slates known to us. The mica so formed is probably what in its more advanced stages of development is often known as sericite. $c$

As slates are evidently derived from the waste of granitic rocks this material must have contained clastic mica, as do the shales, and wherever the feldspar of the granite or gneiss had previously been sericitized such sericite must have found its way into the sediments and into the slate without very great loss by decomposition. As a matter of observation, fine-grained mica-slates do contain occasional scales of muscovite apart from the matrix, which may be of clastic origin, but the micaceous matrix of micaslate is regarded as mainly of metamorphic origin.

A question has also been raised as to the origin of the rutile needles. Roth $d$ is decidedly of the opinion that they belong to the original sediment. Thürach, $e$ Pfaff, $f$ and Credner $g$ find an abundance of them in clay. Rosenbusch $h$ states that while zircon and apatite bear traces of their clastic origin, such traces are entirely absent in both the rutile and the tourmaline. It will be noticed in looking over the 40 microscopic analyses of roofing slates made for this volume by the writer that the abundance of these needles varies greatly. In some very crystalline slates (Peach Bottom, Maine) they are hard to find, and in some less crystalline ones (Arkansas, Vermont) they are very abundant.

The sizes of the mineral particles and the numerical abundance of some of them, as determined during the microscopic study of the roofing slates of Arkansas, California,

$a$ See On the structure and origin of noncalcareous stratified rocks: Quart. Jour. Geol. Soc. London, vol. 36 , pp. $67-77$.

$b$ Neues Jahrb. für Min., etc., 1881, vol. 1, p. 399.

$c$ Hutchins, W. M., Clays, shales, and slates: Geol. Mag., vol. 7, p. 317.

$d$ Doubtless some of the constituents are of secondary origin (as quartz, pyrite, and the products of its oxidation, calcite, hematite, and limonite, gypsum), but the evidence of the secondary origin of the rutile needles does not seem to me convincing. Unstratified sands also contain a series of minerals.-Allgem. u. Chem. Geologie, vol. 2, p. 586.

$\boldsymbol{e}$ Thürach, H., Ueber das Vorkommen mikroskopischer Zirkone u. Titan Mineralien in den Gesteinen: Verh. phys.-math. Gesellsch., Wurzburg, N. F., vol. 18, No. 10, 1884.

$f$ Pfaff, E. Petrographische Untersuchungen über die eocenen Thonschiefer der Glarner Alpen: Sitzungsb. math.-phys. Classe k. k. Akad. der Wissenschaft., Munich, vol. 10, 1880, p. 479.

$g$ Credner, G. R., Die Krystallinischen Gemengtheile gewisser Schieferthone und Thone: Zeitschr. ges. Naturwiss., Halle, 1874 .

$h$ Elemente der Gesteinslehre, p. 424. 


\section{SLATE DEPOSITS AND INDUSTRY OF UNITED STATES.}

Maine, Maryland, New York, Pennsylvania, Virginia, Vermont, and West Virginia, are here summarized:

Quartz, grains: 0.013 to 0.1 millimeter by 0.004 to 0.03 millimeter (exceptionally 0.347 long).

Feldspar (plagioclase), grains: up to 0.047 by 0.052 .

Muscovite (sericite) of matrix: thickness down to 0.00017 , length from 0.006 to 0.06 and over.

Biotite, scales: up to 0.085 by 0.047 (exceptionally 0.2 by 0.09 ) and numbering up to 22 per square millimeter. $a$

Chlorite, scales: 0.047 to 0.17 by 0.006 to 0.1 (exceptionally 0.38 by 0.25 ) and numbering up to 100 per square millimeter.

Carbonate, rhombs: 0.002 to 0.065 .

Rutile "needles:" 0.0017 tc 0.095 by 0.0006 to 0.006 millimeter and numbering from 1,000 to 1,850 per square millimeter, or 900,000 per square inch. Those in Arkansas slates number up to about 2,400 per square millimeter.

Pyrite, lenses and distorted cubes: 0.002 to 0.094 by 0.47 (rarely 0.6 by 0.1 ) and numbering up to 300 per square millimeter.

Pyrite, spherules: 0.0017 to 0.027 millimeter and numbering up to 600 per square millimeter.

Magnetite, distorted octahedra: 0.009 to 0.14 by 0.02 (rarely 0.17 by 0.04 ) and numbering up to 43 per square millimeter.

Hematite, dots: 0.0004 to 0.01 millimeter.

Tourmaline, prisms: 0.005 to 0.076 by 0.001 to 0.009 millimeter.

Andalusite, prisms: 0.008 by 0.001 to 0.11 by 0.03 (exceptionally 0.2 by 0.02 ) and numbering up to 80 per square millimeter.

Lenses of chalcedonic quartz and rhudochrosite: 0.32 by 0.15 millimeter (sometimes 1 millimeter long).

Lenses of biotite and quartz: up to 0.565 by 0.14 (rarely 1 by 0.075 ).

Lenses of pyrite and quartz: up to 0.75 by 0.12 millimeter.

Lenses of chlorite or quart\% or muscovite or combinations of them, containing each an andalusite prism and measuring 0.04 to 0.25 by 0.04 to 0.1 millimeter.

As the mineral constituents of aqueous-sedimentary slates were either (1) derived from older rocks and deposited either as mechanical sediments or chemical precipitates, or (2) formed during metamorphism, or (3) derived from marine organisms, they are to be classified as follows:

Classification of mineral constituents of slates.

\begin{tabular}{|c|c|c|c|}
\hline Clastic. & $\begin{array}{l}\text { Clastic or authig- } \\
\text { enous. }\end{array}$ & Authigenous. & Organic. \\
\hline $\begin{array}{l}\text { Quartz grains. } \\
\text { Feldspar grains. } \\
\text { Zircon grains. } \\
\text { Muscovite scales. } \\
\text { Kaolin. } \\
\text { Apatite. } \\
\text { Magnetite? } \\
\text { Carbonates, granular. }\end{array}$ & $\begin{array}{l}\text { Rutile needles. } \\
\text { Tourmaline. }\end{array}$ & $\begin{array}{l}\text { Quartz, chalcedonic } \\
\text { Quartz, vein. } \\
\text { Muscovite (sericite). } \\
\text { Biotite. } \\
\text { Chlorite, interleaved with } \\
\text { muscovite or biotite. } \\
\text { Pyrite. } \\
\text { Magnetite. } \\
\text { Hematite. } \\
\text { Carbonates of lime, iron, } \\
\text { magnesia. } \\
\text { Carbonate of manganese. } \\
\text { Andalusite. } \\
\text { Barite. } \\
\text { Gypsum. } \\
\text { Talc. }\end{array}$ & $\begin{array}{l}\text { Carbonaceous matter. } \\
\text { Graphite. }\end{array}$ \\
\hline
\end{tabular}

$a$ The square millimeter given comprises the thickness of the thin section. 
Of course these secondary or authigenous minerals were merely new combinations, sometimes in crystalline form, of clastic ones. Thus the hematite originated in sedimentary limonite. The andalusite $\left(\mathrm{Al}_{2} \mathrm{O}_{3}, \mathrm{SiO}_{2}\right)$ probably originated in kaolin.

The principal elements in roofing slates, as determined by the chemical analyses given in the section on the chemistry of slate (p. 34), are to be attributed to the mineral constituents in the following way:

$\mathrm{SiO}_{2}$ to quartz, muscovite, biotite, feldspar, chlorite, tourmaline, andalusite, zircon, kaolin.

$\mathrm{TiO}_{2}$ to rutile.

$\mathrm{Al}_{2} \mathrm{O}_{3}$ to muscovite, biotite, feldspar, chlorite, tourmaline, andalusite, kaolin.

$\mathrm{Fe}_{2} \mathrm{O}_{3}$ to hematite, magnetite, muscovite, biotite.

$\mathrm{FeO}$ to chlorite, magnetite, carbonate, biotite.

$\mathrm{MnO}$ to rhodochrosite.

$\mathrm{CaO}$ to plagioclase, calcite, carbonate of lime, iron and magnesia, apatite.

$\mathrm{BaO}$ to barite and some silicate.

$\mathrm{MgO}$ to chlorite, biotite, carbonate.

$\mathrm{K}_{2} \mathrm{O}$ to muscovite, orthoclase.

$\mathrm{Na}_{2} \mathrm{O}$ to muscovite, plagioclase.

$\mathrm{Li}_{2} \mathrm{O}$ to tourmaline.

$\mathrm{H}_{2} \mathrm{O}$ to muscovite, chlorite, limonite, kaolin.

$\mathrm{P}_{2} \mathrm{O}_{5}$ to apatite.

$\mathrm{CO}_{2}$ to calcite, rhodochrosite, and carbonate of lime, iron, and magnesia.

$\mathrm{FeS}_{2}$ to pyrite.

$\mathrm{SO}_{3}$ to barite and gypsum.

$\mathrm{C}$ to graphite, coaly matter.

$\mathrm{Zr}_{2} \mathrm{O}$ to zircon.

The mineral sources of the nickel, cobalt, chromium, vanadium, and ammonia detected by Doctor Hillebrand in the slates of Vermont and New York have not been determined.

\section{SPO'TNED SLATES.}

The spots in roofing slates have long attracted attention." In the eastern New York and western Vermont slate region the purple slates often have green spots of circular or oval, but frequently of irregular outline. These spots sometimes occur only along lines of bediling and correspond to or pass into green "ribbons." In places, however, an entire bed of purple slate several feet thick is irregularly spotted throughout. The red slates are also often spotted. The spots are frequently circular or oval and measure from a fraction of an inch to several inches in diameter and of pale-green color with or without a purple border. Some of the spots, however, have no symmetry whatever. In order, if possible, to throw some new light on this subject a few thin sections were prepared across small spots in directions parallel to and across the cleavage, and in the case of the spotted red slates chemical analyses were made by Doctor Hillebrand of the green center of tise spot, of its purple rim, and of the outer red slate.

$$
\text { MICROSCOPIC: ANALYSES. }
$$

An elliptical green spot, 1 by $\frac{3}{4}$ inch, in purple Cambrian slate from the Lake Bomoseen Slate Company's quarry, at Cedar Point, Castleton, Vt., in a section cut parallel to cleavage, shows, in the green part, muscovite scales lying in all directions, large chlorite scales, quartz fragments, carbonate rhombs, and a few irregular spherules of pyrite. In the center is some opaque, noncalcareous matter, partly sur-

a Comparative view of the cleavage of crystals and slate rocks, by John Tyndall: Phil. Mag., vol. 12, July, 1856. On the disposition of iron in variegated strata, by George Maw: Quart. Jour. Geol. Soc., vol. 24, p. 379; also On variegated Cambrian slates, by the same author, I'l. XIV, figs. 29, 31, 32, London, 1868. Les schistes de Fumay, by Gosselet: Ann. Soe. Géol. du Nord, vol. 10. pp. 63-86, Lille., 1884; same author, L'Ardenne, 1888, p. 35. Text-book of Geology, by Archibald Geikie, 4th ed., vol. 1, p. 451 (2), 1893. Lehrbuch der Petrographie, by F. Zirkel, 2d ed., vol. 3, pp. 296-297, 1894. 
rounded by an aggregation of spherules of pyrite in a cloud of rutile needles. There are also cracks filled with secondary sericite. In the surrounding purple the same elements recur, but the pyrite is much more abundant, measuring up to $0.021 \mathrm{~mm}$. There are also many dots of $\mathrm{Fe}_{2} \mathrm{O}_{3}$ from less than 0.003 to $0.009 \mathrm{~mm}$., and rutile needles up to $0.012 \mathrm{~mm}$. in length.

An elliptical green spot, 3 inches long, with a purple rim, in Ordovician red slate from the National Red Slate Company's quarry north-northwest of Raceville (Speciinen D. XIV, '95, 397a), when cut transversely to the cleavage, measures a half inch in thickness and shows a black streak 1 inch long in the center. The central streak consists of strings of minute irregular lenses of cryptocrystalline quartz and possibly carbonate of manganese (rhodochrosite) containing spherules of pyrite. The green part consists of a mass of fibers of muscovite, which polarize as one mineral with much carbonate and many lenses, and also quartz grains. In the purple rim there is a decrease of carbonate and the hematite fragments begin to appear and become still more abundant in the surrounding red slate itself.

A green spot in Ordovician red slate (D. XIV, '95, 201c), from the Empire Red Slate Company's quarry, a mile north of Granville, cut parallel to the cleavage, shows slate needles $\left({ }^{\prime} \mathrm{TiO}_{2}\right)$ up to $0.043 \mathrm{~mm}$. long, carbonate rhombs up to $0.030 \mathrm{~mm}$., chlorite scales up to $0.030 \mathrm{~mm}$., angular quartz grains up to $0.039 \mathrm{~mm}$., and prisms of tourmaline up to 0.021 by $0.002 \mathrm{~mm}$. The surrounding red slate, that of Analysis $\mathrm{K}, \mathrm{p} .73$, has been described in the general description on p. 72 .

Another spot, almost circular, 0.44 inch in diameter, from a piece of red slate (D. XIV, '95, 201 1) from the same quarry, cut parallel to the cleavage, shows a central dot 0.03 inch in diameter, consisting mainly of carbonate and of a dense brown material. About this is a zone about 0.1 inch wide, of elliptical shape, of carbonate, with some fibrous quartz along the margin. Then comes a zone 0.08 inch wide, of green slaty material, containing angular quartz grains, muscovite scales, rutile needles, nodules of pyrite, and thinly disseminated areas and rhombs of carbonate; then a very narrow zone, made up entirely of carbonate and pyrite. Outside of this, another green slate zone, 0.08 inch wide, like the first, but with very little carbonate. The angular quartz grains measure up to $0.030 \mathrm{~mm}$. There are also slender tourmaline prisms. Outside of all comes the red slate, full of $\mathrm{Fe}_{2} \mathrm{O}_{3}$ pigment. Chlorite was not detected in the green zones, but it may be present in minute scales.

CHEMICAL ANALYSES OF SPOTS IN RED SLATE.

The specimen $(Q, R)$ analyzed by Doctor Hillebrand came from the same quarry as the large spot described above. It was a green spot with purple rim, in red slate. The analysis of the red slate $\mathrm{M}$, on page 73 , is repeated for comparison.

Chemical analyses of spotted red slate.

\begin{tabular}{|c|c|c|c|c|c|c|c|}
\hline & \multicolumn{3}{|c|}{ Specimen. $a$} & & \multicolumn{3}{|c|}{ Specimen. $a$} \\
\hline & M. & Q. & R. & & M. & Q. & R. \\
\hline $\mathrm{SiO}_{2}$ (silica) $\ldots . . . \ldots \ldots$ & 63.88 & 64.59 & 65.44 & MgO (magnesia) .... & 5.37 & 5.12 & 4.92 \\
\hline $\begin{array}{l}\mathrm{TiO}_{2} \text { (titanium dioxide, } \\
\text { rutile) ............................ }\end{array}$ & .47 & .51 & .52 & $\mathrm{~K}_{2} \mathrm{O}$ (potassa) $\ldots .$. & $\begin{array}{r}3.45 \\
20\end{array}$ & 3. 70 & 3. 57 \\
\hline $\mathrm{Al}_{2} \mathrm{O}_{3}$ (alumina) $\ldots \ldots \ldots .$. & 9.77 & 10.23 & 9.38 & 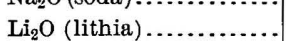 & Str.tr. & Str.tr. & Str. tr. \\
\hline $\mathrm{Fe}_{2} \mathrm{O}_{3}$ (ferric oxide) $\ldots . . .$. & 3.86 & 1.79 & 1.09 & $\mathrm{H}_{2} \mathrm{O}$ (water below $110^{\circ} \mathrm{C}$.) & .27 & .28 & .25 \\
\hline $\mathrm{FeO}$ (ferrous oxide) ....... & 1.44 & 1.19 & 1. 06 & $\mathrm{H}_{2} \mathrm{O}$ (water above $110^{\circ} \mathrm{C}$.) & 2.48 & 2.29 & 2.10 \\
\hline MnO (manganous oxide) - & .21 & .26 & $\begin{array}{r}.32 \\
-3 r a c e\end{array}$ & $\mathrm{P}_{2} \mathrm{O}_{5}$ (phosphoric oxide) & .08 & .08 & .08 \\
\hline $\begin{array}{l}\text { NiO (nickelous oxide) ... } \\
\text { CoO (cobaltous oxide) ... }\end{array}$ & $\begin{array}{l}\text { Trace. } \\
\text { Trace. }\end{array}$ & $\begin{array}{l}\text { Trace. } \\
\text { Trace. }\end{array}$ & Trace. & $\mathrm{CO}_{2}$ (carbon dioxide) $\ldots$. & 5.08 & 5.84 & 6.55 \\
\hline $\mathrm{CaO}$ (lime) $. . . \ldots \ldots \ldots \ldots . . .$. & 3.53 & 4.07 & 4.53 & $\mathrm{FeS}_{2}$ (pyrite).. & Trace. & Trace. & .04 \\
\hline BaO (baryta) ............. & .05 & .05 & .06 & & 100.14 & 100.23 & 100.13 \\
\hline
\end{tabular}

$a \mathrm{M}(=\mathrm{D} . \mathrm{XIV}, 95,397 a)$, red slate, 1 mile north-northwest of Raceville, in Granville, Washington County, N. Y., about a spot; $Q$, purple rim of the spot; $R$, green portion of the spot. 
Doctor Hillebrand adds this observation:

Calculation shows that with no $\mathrm{CO}_{2}$ there would be only enough $\mathrm{CaO}$ for the $\mathrm{P}_{2} \mathrm{O}_{5}$, and, further, that the result would be no Mno. How much $\mathrm{FeO}$, if any, exists as carbonate is not indicated. If, after allowing for apatite, for $\mathrm{MnCO}_{3}$, and $\mathrm{CaCO}_{3}$, the remainder of the $\mathrm{CO}_{2}$ is charged to $\mathrm{MgO}$, we find the proportions shown in the columns below. $a$

\begin{tabular}{|c|c|c|c|}
\hline & M. & Q. & R. \\
\hline 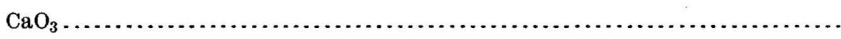 & 6.14 & 7.11 & 7.93 \\
\hline 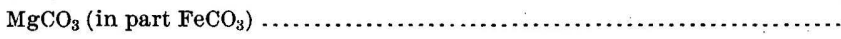 & 4.22 & 4. 77 & 5.36 \\
\hline 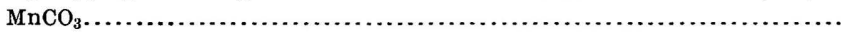 & .38 & .47 & .57 \\
\hline
\end{tabular}

$a$ See Doctor Hillebrand's chemical note, p. 39 .

DISCUSSION OF THE SPOTS.

From Doctor Hillebrand's analyses it would appear that there is a decrease of the carbonates of lime and manganese and magnesia and of silica and rutile from the center of the spot outward and an increase of $\mathrm{Fe}_{2} \mathrm{O}_{3}$ in the same direction.

The main results of the microscopic and chemical analyses agree even as to the relative amount of pyrite. The difference in color from the green to purple and red is manifestly due to the differences in the amount of hematite. Pyrite, rutile, carbonate, and tourmaline are more abundant within the spots than without them.

Certain green fossil impressions in purple slate at Middle Granville, N. Y., may throw some light on the origin of these spots. In this case the effect of organic matter, whether the carbonaceous matter of the lining of an annelid boring or from a marine alga, has been to diminish the quantity of $\mathrm{Fe}_{2} \mathrm{O}_{3}$ in the slate, and possibly to increase the amount of chlorite. $a$ Gosselet regards the spots as the result of the reduction of the hematite $\left(\mathrm{Fe}_{2} \mathrm{O}_{3}\right)$ by decaying organisms to the ferrous oxide $(\mathrm{FeO})$ and its removal as an organic salt or as a carbonate. He observes that the green spots in purple tiles wear less readily than the rest of the tile, because they contain more quartz, and this $\mathrm{SiO}_{2}$ he attributes to infiltration. ${ }^{b}$

In the spots examined from the New York and Vermont slates the marked decrease of $\mathrm{Fe}_{2} \mathrm{O}_{3}$ is accon panied by a marked increase of carbonate of lime, iron, and manganese, $c$ and of $\mathrm{SiO}_{2}$, also by a slight increase, in some of the thin sections at least, of $\mathrm{FeS}_{2}$. Carbonates are also characteristic of the spots in some European slates. $c$ The increase of the carbonates may be directly connecterl with the production of $\mathrm{CO}_{2}$ by decaying organisms and the consequent decrease of the $\mathrm{Fe}_{2} \mathrm{O}_{3}$. Not impossibly the organism may have had a calcareous exoskeleton which was dissolved and then redeposited as crystalline $\mathrm{CaCO}_{3}$. The infiltration of $\mathrm{SiO}_{2}$ and the formation of chalcedony may be purely secondary, and likewise the deposit of $\mathrm{FeS}_{2}$, or there may have been some precipitation of $\mathrm{FeS}_{2}$ about the decaying organism, as seems to have been the case in some fossiliferous sediments. At any rate, the rim of intermediate compositon would be the zone in which chemical reaction was less effective.

In view of all these facts anıl indications, the spots may be safely regarded as probably produced by chemical changes in the sediments consequent upon the decay of organisms.

If this be the correct view, the green ribbons, which traverse both purple and red slate, would correspond to small deposits of decomposing organic material that

$a$ See Tyndall, Maw, Gosselet, Geikie, and Zirkel, as indicated by titles given in footnote on p. 15.

$b$ Maw (loc. cit.) had analyses made of dark greenish ribbons in the Welsh blue slates, and found

that the ribbons contained 6 per cent more $\mathrm{SiO}_{2}, 7$ per cent more $\mathrm{Al}_{2} \mathrm{O}_{3}, 4 \frac{1}{2}$ per cent more $\mathrm{MgO}(=7$ that the ribbons contained 6 per cent more $\mathrm{SiO}_{2}$, per cent more , but 4 per cent less $\mathrm{Fe} \mathrm{O}_{3}, 1$ per cent less $\mathrm{FeO}$, and $3 \frac{1}{2}$ per cent less $\mathrm{K}_{2} \mathrm{O}$ than the adjacent blue beds. Under the microscope the green ribbons showed more feldspár and chlorite. He attributes these differences to change in sedimentation.

$c$ See Zirkel, loc. cit.

Bull. $275-06-2$ 
effected similar changes in the $\mathrm{Fe}_{2} \mathrm{O}_{3}$ of the argillaceous sediments. Where a bed of quartzite forms the center of such a ribbon quartzose sedimentation must have taken place also, and possibly may have been the very condition which proved favorable to marine life.

\section{IGNEOUS SLATES.}

Most remarkable are the green slates from the English Lakf district (Buttermere, Tilberthwaite, etc.), which consist of volcanic ash and which have long been known in England as excellent roofing material. These have recently been chemically and microscopically analyzed and described. $a$ These slates are found to consist chiefly of chlorite, calcite, quartz (mostly secondary), and muscovite, but contafn also andesitic lapilli, feldspar, garnets, sphene, and anatase. Slate needles and tourmaline are conspicuously absent. The chemical analyses show the following important constituents:

$\mathrm{SiO}_{2}$ $50.16-54.02$

$\mathrm{Al}_{2} \mathrm{O}$ $11.94-17.85$

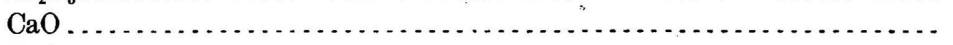

$3.67-6.46$

$\mathrm{FeO}$

$5.97-7.06$

$\mathrm{CO}_{2}$ $2.45-5.41$

$\mathrm{CO}_{2}$ if calculated to $\mathrm{CaCO}_{3}$ would give from 5.56 to 12.29 per cent of $\mathrm{CaCO}_{3}$. Specific gravity ranges from 2.775 to 2.788 . The percentage of $\mathrm{SiO}_{2}$ is low, and that of $\mathrm{FeO}$ is near that of the "unfading green" slate of Vermont (p. 107).

Still more remarkable are the slates first described by Mr. E. C. Eckel in 1903, $b$ which seem to have been formed directly from igneous rock by shearing. They show from 3 to 9 per cent less $\mathrm{SiO}_{2}$ than the English ash slates and more than double the per cent of $\mathrm{MgO}$ of the European and American roofing slates of aqueous-sedimentary origin, analyses of which are given under the heading Chemistry of slate, (p. 34). These slates are fully described by Mr. Eckel on page 57 .

The state of science on the remaining structural, geological, and chemical features of slate will be given under the three headings which follow.

\section{STRUCTURE ,OF SLATE. $c$}

\section{BEDDING.}

Ordina:y planes of bedding may be defined as those which are approximately parallel to the surface of the water in which the sediment is formed. If the sediment changes in character, then a horizontal bed of different material results. If, deposition being interrupted, annelids creep over the bottom or algæ decompose there, and the same kind of sedimentation be afterwards resumed, then two horizontal beds of the same material will result, separated by a plane covered with trails and impressions. Some bedding planes are due to the changing size or arrangement of the particles, some may be the result of contraction in drying, others are the effect of vertical compression. Whatever explanation may be offered for bedding, the bed is the starting point in a slate quarry, for the direction of the bed indicates (cleavage, etc., being equal) where the same quality of slate is likely to recur.

In those places where folding has brought the bedding plane to the angle of inclination required by the cleavage, the unaltered sedimentary particles of the slate still retain their parallelism to the bedding, i. e., cleavage and bedding are parallel, but in all other places cleavage is necessarily more or less transverse to bedding. This,

a Hutchins, Maynard, The ash slates of the Lake District: Geol. Mag. London, 1892. Reade, T. Mellard, and Holland, Philip, The green slates of the Lake District, with a theory of slate structure and slaty cleavage: Proc. Liverpool Geol. Soc. (1900-1901), 1901.

b Bull. U. S. Geol. Survey No. 225, p. 419; also "On a California roofing slate of igneous origin," in Jour. Geol., vol. 12 , p. 15, Jan.-Feb., 1904 .

$c$ This chapter in its original form appeared in part 3 of Nineteenth Ann. Rept. U. S. Geol. Survey, in 1899 , but its matter is here revised and brought up to date. 


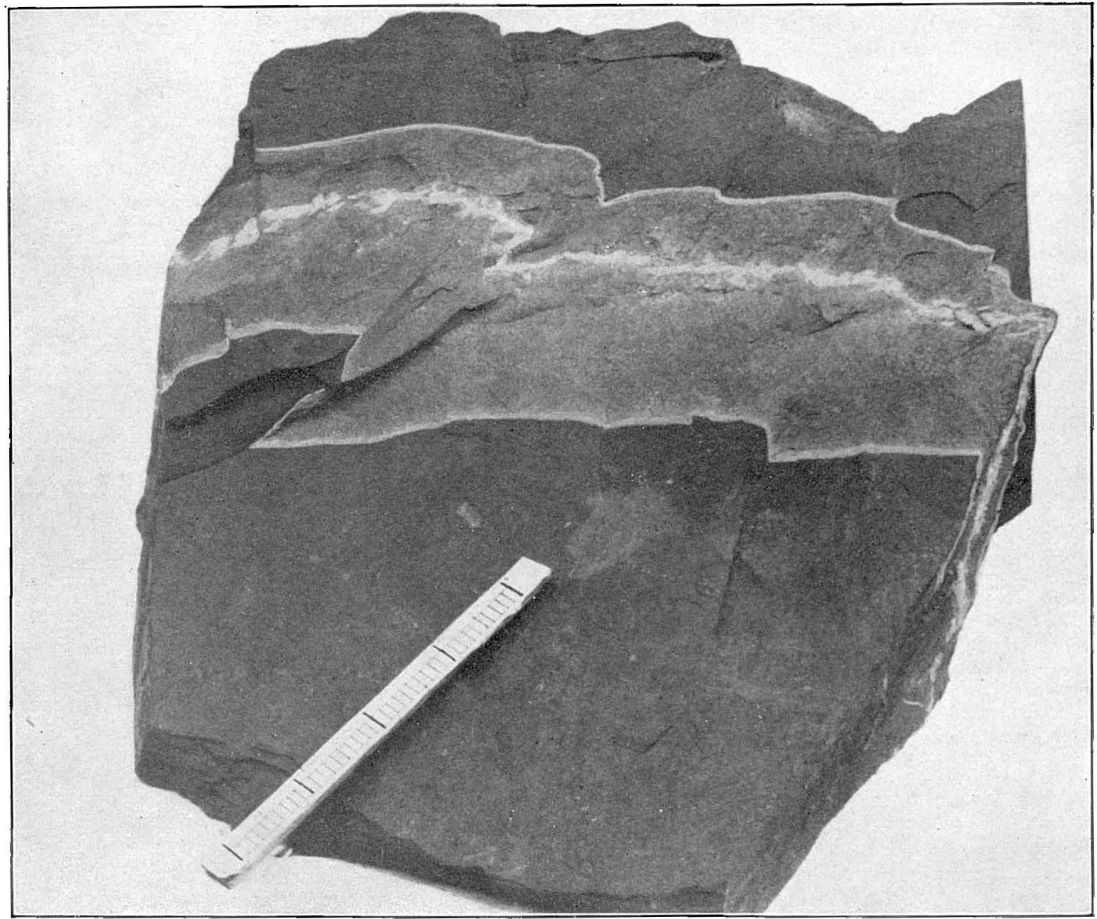

A. RED SLATE WITH BED OF LIMESTONE AND GREEN SLATE.

Block of reddish slate from quarries $1 \frac{1}{2}$ miles south of Hatch Hill, in Whitehall, N. Y., with bed of limestone bordered by green and purple slate, making a "ribbon," an inch in vertical thickness, crossing the cleavage diagonally. Scale on rule is 4 inches long.

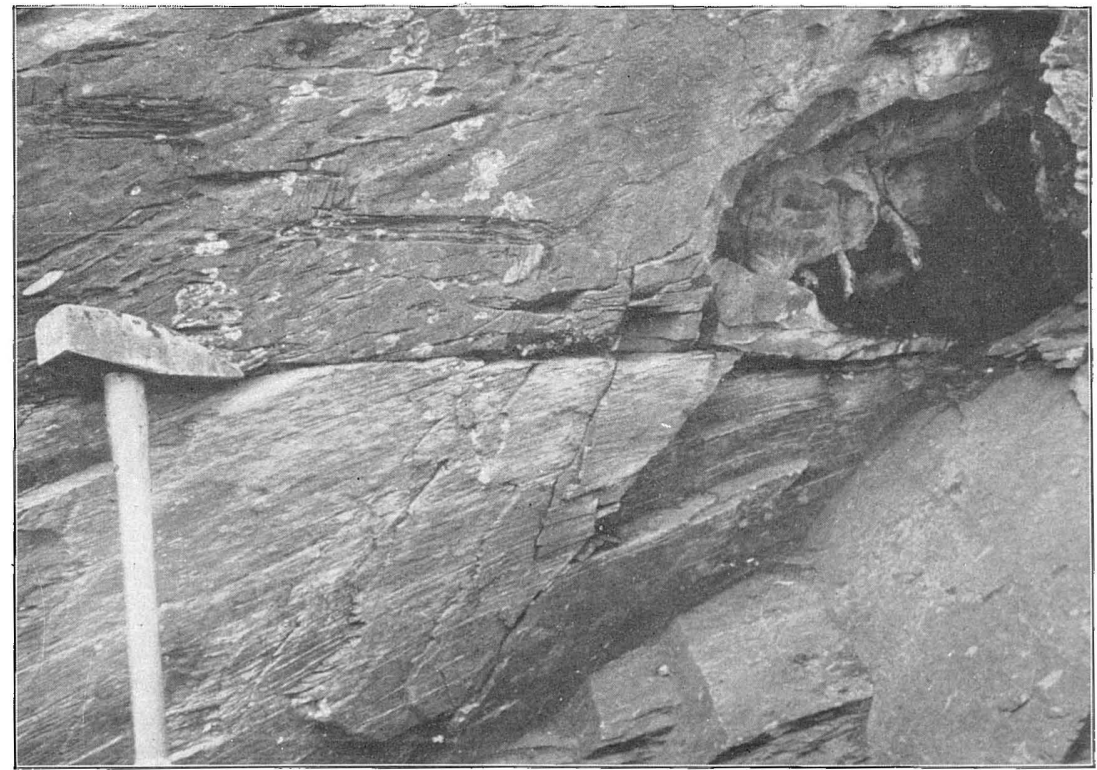

\section{B. BED OF SANDSTONE RESTING ON SLATE.}

Horizontal bed of sandstone with calcareous concretions having their longer axes parallel to the bedding, overlying greenish slate with cleavage dipping $20^{\circ}$ and joints $45^{\circ}$. An irregular cleavage continues in the sandstone. Eddy Hill, Fair Haven, $V_{t}$. One foot of sledge handle is in sight. 



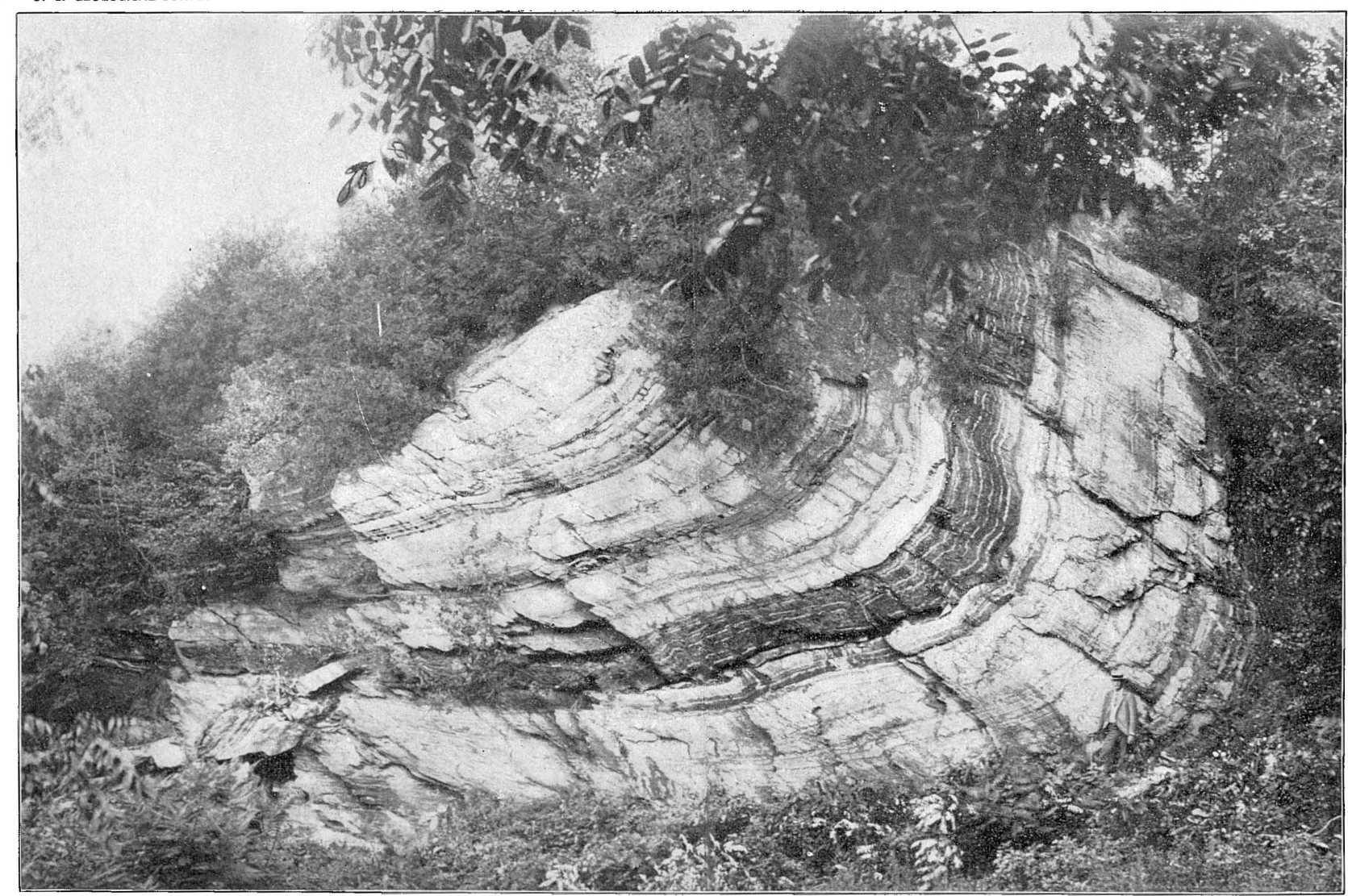

SYNCLINE OF BLACK AND GRAY BANDED SLATE AT WEST CASTLETON, VT.

Showing the effect of erosion upon the more calcareous beds. Cleavage dips $30^{\circ}$ to the right, or east. 

of course, assumes that the slate beds still retain the position they had when slaty cleavage was set up in them.

Pl. II, $B$, shows a ledge of green roofing slate with a cleavage dipping $20^{\circ}$ east (strike N. $15^{\circ}$ W.); joints striking N. $30^{\circ}$ E. and dipping $45^{\circ}$ east. The upper part is a quartz sandstone or grit, with calcareous concretions containing Lower Cambrian trilobites. The direction of the axial planes of the calcereous bodies and the direction of the line of contact between the slate and sandstone show the direction of the bedding to be horizontal.

The "ribbons" of the Pennsylvania quarries shown in figs. 6-9 and Pls. XIII, XIV, XVIII-XX, consist of small beds of quartz sandstone or grit in which the particles are held together by a calcareous and sometimes a sericitic cement, the original clay having gone into muscovite. Sometimes the slate beds are separated, as in the Vermont and New York quarries (PIs. XXIII, XXIV), by beds of calcareous quartzite reaching several inches in thickness and consisting of grains of quartz sand cemented together by secondary quartz and calcite and other carbonates. Such beds may be but a fraction of an inch in thickness, and consist mainly of carbonate, as in the syncline at West Pawlet, Vt., shown in Pl. XXV. In some cases bedding is indicated simply by a variation in the amount of lime in successive beds, as in the syncline at West Castleton, Vt., shown in Pl. III. Here the solution of the lime by the acids of the atmosphere has etched the joint face, as it were, and the more calcareous beds thus stand back from the less calcareous ones.

Planes of bedding may be indicated by the position of fossils, as the brachiopods and trilobites at the Arvonia quarries in Virginia, or by bifurcating impressions, possibly made by seaweeds, and serpentine ones by annelids, or by the small black beds in green slate due to the decomposition of various marine organisms, all of which may be seen in the slate quarries of western Vermont and eastern New York.

Pl. II, $A$, from a photograph of a piece of red slate from the old quarries of the Fair. Haven Red Slate Company, in the southeast corner of Whitehall, N. Y., shows a bed an inch thick crossing the cleavage diagonally, and therefore spreading out to double that width on the cleavage surface. "In the center of the "ribbon" is a bed one-fourth inch thick of greenish limestone, and on either side of the ribbon is a very thin rim of green slate; the rest of it is purple. Under the microscope the composition of these little beds is this: The central green consists of calcite and siderite rhombs; some of the siderite is altered to limonite. There are large quartz grains, muscovite scales without parallel orientation, and occasional plagioclase grains. The purple consists chiefly of scales of muscovite and chlorite, lying in two directions, at right angles to each other, irregular dots of hematite, some carbonate rhombs, quartz grains, and rarely a grain of plagioclase. The thin green strips on the sides contain less hematite than the purple, and a large number of the muscovite and chlorite scales lie parallel to the bedding and transverse to the cleavage. The red slate itself is like the purple, but contains far more hematite and probably less chlorite. The iron obscures the other minerals. In this specimen the central bed of quartzose limestone is probably due to change of sediment. The varying amount of ferric oxide in the purple and green parts of the ribbon as compared with the red of the slate beds may be due to a chemical change brought about by the decomposition of organisms on the sea floor, as has been shown on pages 15-18 to be probably true of the green and purple spots in the same slate. Sometimes the quartzose ribbons of the red slate are parallel to the cleavage. This parallelism between bedding and cleavage characterizes some of the Maine and Vermont quarries (see Pl. XII).

The Vermont purple slate frequently has small beds of green slate, with or without a central band, crossing the cleavage; and the village sidewalks in that region are sometimes flagged with such purplish green-banded slate. When, owing to folding and pitch, the grain of such slates is not at right angles to the bedding the roofing slates have diagonal green ribbons. These green ribbons, both in the red slate 


\section{PLATE IV. \\ PLICATED AND FAULTED BEDS IN SLATE.}

(A) Extremely plicated bed of quartzose limestone or calcareous quartzite in Cambrian slate at Fair Haven, Vermont. Natural size. The slate on both sides of the bed for a half inch is green; beyond that, purplish.

$(B)$ Extremely plicated bed of quartzose limestone or calcareous quartzite in Cambrian slate at Fair Haven, Vermont. Reduced one-half.

(C) Faulted quartzite bed in slate at Meadow Slate Company's quarry, Fair Haven, Vermont. Normal fault.

(D) Faulted quartzite bed in slate at Eureka quarry, Poultney, Vermont. Reversed fault.

(E) Thin section of faulted calcareous bed at Pawlet, Vermont, given in Pl. XXIII, $D$, showing adjustment of cleavage to faulting and production of secondary cleavage. Enlargement, $3 \frac{1}{2}$ diameters.

$(F)$ Thin section of plicated and faulted beds of calcite and quartz separating beds of purple and green Cambrian slate at Blissville, Castleton, Vermont. Enlargement, 2 diameters. Both calcite and quartz beds are bordered on both sides with chlorite scales.

$(G)$ Dislocated beds of quartzite in purple Cambrian slate at old quarry, about one mile south of West Castleton, Vermont. A fragment of a bed of quartzite has been turned about into the cleavage foliation and across smaller beds of quartzite. By L. M. Prindle.

$(H)$ Plicated and folderl quartzite in Cambrian slate at Fair Haven, Vermont. Height, 40 feet. Minor plications somewhat enlarged. 


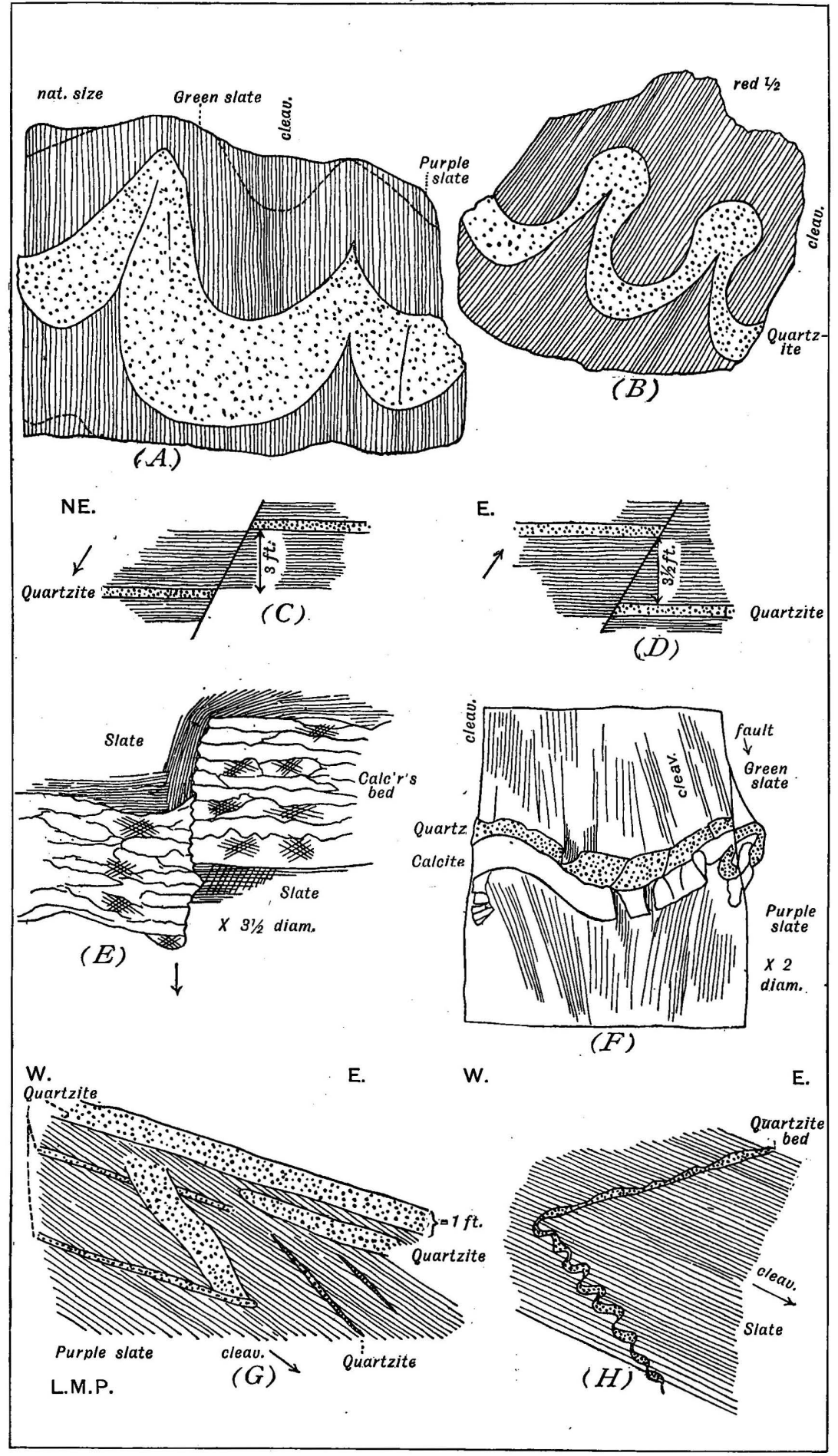

PLICATED AND FAULTED BEDS IN SLATE. 

of New York and the purple of Vermont, run into planes or rows of spots of various sizes, usually more or less oval in outline. When a series of such spots are in line it indicates the course of the bedding.

The small beds or ribbons are often plicated, as in figs. $Q, R, \mathrm{Pl}$. XXIV. Pl. IV, $E$, is a microscopic drawing of a thin section of the plicated bed of Pl. XXIII, $D$. The bed here consists of calcite and vein quart\%, the original calcareous sediment having been crystallized and vein quartz deposited. The diagram shows the faulting of the bed, the bending, of the cleavage foliation, and the slip cleavage caused by the dislocation. The plication of such small beds of quartzose limestone and calcareous quartzite is sometimes extreme, as shown in Pl. IV $, A, B, H$. The folding in such cases seems to have been preserved only in the hard beds, while in the more plastic material of the slate on either side slaty cleavage has obscured or effaced the bedding. $a$

Fig. $F$, Pl. IV, represents a plicated bed of quartz and one of calcite separating beds of purple and green slate. Under the microscope both quartz and calcite beds are bordered with chlorite scales on the outside, and separated by such scales; there is also some pyrite along the edges. The cleavage of the slate is at right angles to the course of the bedding, but is slightly deflected near the plicated beds. In several places the slaty material has been drawn partly into the bed.

A thin section of a small plicated bed of quartzite in the purple slate of the Cedar Point slate quarry, in Castleton, Vt., shows the following: The bed consists mainly . of quartzite, but this contains grains of plagioclase, rhombs of carbonate, probably calcite, and scales of muscovite. Toward the slate there are coarse fibers of muscovite. The slate merges into the quartzite, sending out long streamers of sericite, which penetrate between the grains of quartz and calcite. The slate contains large scales of chlorite within the meshes of sericite, which scales lie at right angles to the cleavage, i. e., parallel to the course of the bed. It also contains grains of quartz. The fibrous character of the slate is apparent at the border of the quartzite bed. The significance of such a bed is that sandy material was deposited for a brief interval during the deposition of the finer material which produced the slate; there were grains of quartz and of feldspar, and probably scales of mica, together with calcareous mud. Under the compression and the chemical changes which accompanied it the quartz grains were cemented into quartzite, the calcareous mud was crystallized, and the bed was plicated and became entangled with the slaty material. The slaty material itself was also somewhat plicated, and a secondary cleavage (slip cleavage) was produced in it.

Pl. V, $A$, from the Ordovician syncline at West Castleton, also illustrates this plication of quartzite beds and the overturning of the folds. Fig. T, on Pl. XXIV, shows these features on a larger scale.

Exceptionally the quartzite beds seem to have been pushed out of their normal parallelism, even without folding or faulting.

A case of brecciation on a somewhat large scale is shown in fig. $G, \mathrm{Pl}$. IV, taken near fig. T, Pl. XXIV.

Frequently, however, the bed surface is simply a parting whose meanderings must be carefully followed in order to distinguish it from fractures of various kinds, as at the West Pawlet syncline, Pl. XXV; or the bedding may be indicated by the weathering out of calcareous matter from the slate itself, some beds containing more of it than others, as at the syncline at West Castleton, Pl. III. The rock at. West Castleton is a shaly slate, consisting of alternating light and dark gray bands, i. e., beds of muscovite and chlorite scales, grains of quartz, spherules of pyrite, and some carbonate, but there is more carbonate in the gray bands than in the black ones, which contain more carbonaceous matter. Now and then there is a minute bed con-

$a$ See C. H. Hitchcock, Second Ann. Rept. Geol. Maine, 1862, p. 285, fig. 45, where a bed of strongly plicated.limestone lies between unplicated beds of slate. See also the classic figure of H. C. Sorby given in his paper, On the origin of slaty cleavage: Edinb. New Phil. Jour., vol. 55, July, 1853, pp. 139, 140, , which was reproduced by Tyndall in his Roy. Inst. Lecture, and also by Phillips in his British Assoc. 'Report on cleavage. 
sisting largely of calcite. This explains why the beds are so clearly and yet so delicately brought out on the joint face. The original sediments had varying amounts of calcareous material in them. The carbon dioxide brought down from the atmosphere by the rain has, as it were, carried away the more calcareous parts, leaving the less calcareous ones in relief.

In many of the eastern New York and western Vermont quarries change of color alone is an indication of the passage from one bed to another. This change may be gradual or abrupt. But color is not an infallible guide, as the red slate sometimes passes into the green along the same bed, and there is no reason why the Cambrian purple should not likewise pass into the green of the same formation.

In cases where there are no fossil impressions or intervening beds of very different material or partings or slight changes in the composition of the slate itself, producing changes of color or different degrees of erodibility, the course of the bedding can sometimes be made out in a thin section cut transverse to the cleavage when examined under the microscope. There may be an occasional arrangement of the particles parallel to the original bedding or an extremely minute bed of other material, or lines of different particles may cross the cleavage foliation. Fig. C on PI. VI illustrates cases of this kind.

Gosselet $a$ gives some remarkable instances of intense and complex folding of beds of slate on a large scale. These great folds are very acute and overturned. In some places shafts have been dug through other rocks in order to reach underground portions of synclines and anticlines and quarry the slate. Slate quarrying in the Ardennes thus resembles coal mining in a region of intense folding.

\section{- SLATY CLEA VAGE.}

The causes and the structure of slaty cleavage have already been discussed under the headings "Origin of slate" and "Petrographic characters."

In most slate regions cleavage is not coincident with bedding. Its relations to bedding are illustrated in figs. 6-9 and Pls. III, V, $A$; XII-XIV, XVII-XIX, XXIII-XXV. The lowest inclination of slaty cleavage in slate districts visited by the writer is $5^{\circ}-10^{\circ}$ and occurs in Pennsylvania (see Pls. XIII, XIV). ${ }^{b}$ The lowest in the eastern New York and western Vermont belt is $20^{\circ}$. Where the cleavage so nearly approaches horizontality as it does in the first instance its position is probably due in part to a secondary crustal movement and the occasional curvature of both joints and cleavage there also point to such a movement.

Amount of compression in the formation of slaty clearage.-Sorby calculates on a small bed of intensely plicated sandy slate, inclosed in ordinary slate, that the amount of shortening by plication was about 75 per cent, and reasons that the clayey material of the slate itself must therefore have been compressed to the same extent. This is the only way in which the amount of compression actually suffered by a mass of slate could be computed. But this calculation does not take into consideration the elongation of the slate in the shearing.

Relation of cleavage dip to dip of inclosing hard beds.-Gosselet brings out the fact that where a bed of slate lies between beds of a hard rock like quartzite there is a constant geometrical relation between the degree of the cleavage dip of the slate and of the dip of the beds of quartzite. The same thing is true, as he shows, in the horizontal relations between the strike of the cleavage, that of the quartzite bed, and the direction of movement:

Unless the ancient shore yielded to the pressure from the south the lower beds must have had a tendency to rise against that obstacle, to slide as a wedge between the obstacles and the overlying beds. The slaty material inclosed between the two beds of quartzite is thus pushed upward in $\mathrm{a}$ direction which is the component between a vertical line (i. e., vertical to the horizon) and the oblique movement of the wall (i. e., along the surface of the slate bed). Cleavage will be developed along that component, and we actually find that it dips $40^{\circ}$ while the bed dips $27^{\circ}$.

$a$ L'Ardenne, p. 41, fig. 7, Les rapports de Ste. Marie avec les Trésfossés. Les schistes de Fumay, Pl. III, fig. 1: Bond dans les schistes de Fumay.

b See a]so Thirteenth Ann. Rept. U. S. Geol. Survey, Pl. XC, showing a slate quarry near Lebanon, N. Y., with cleavage dipping $10^{\circ}$. 


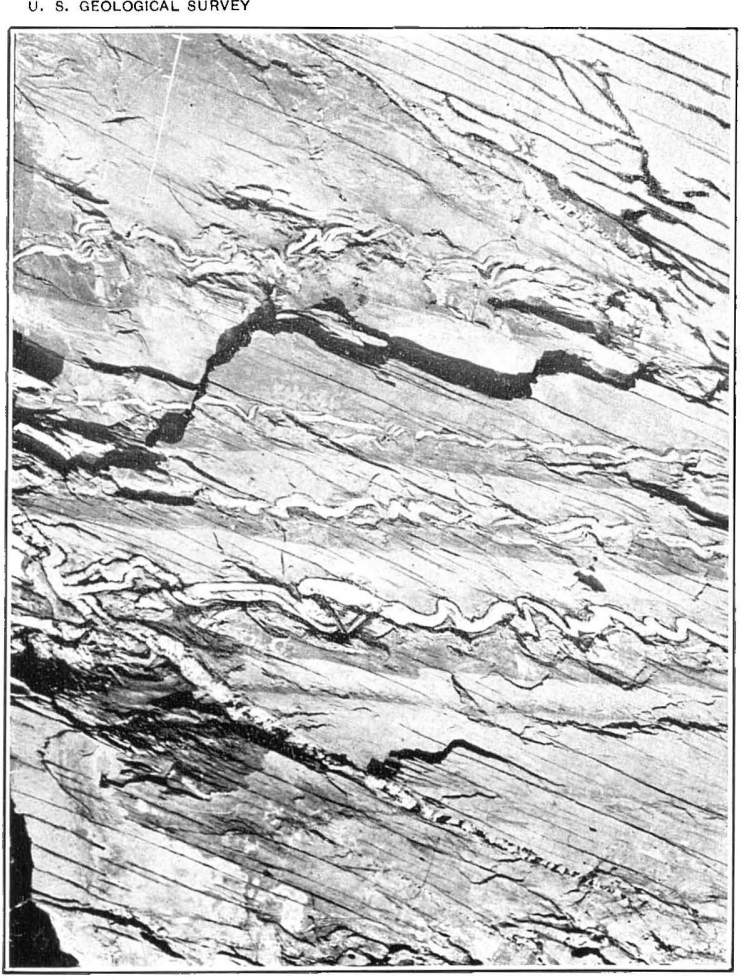

1. QUARTZITE BEDS IN OVERTURNED FOLDS IN SLATE.

Area ( $3 \frac{1}{2}$ by $4 \frac{1}{2}$ feet) of joint face of slate syncline in Plate 111 , showing 4 small beds of quartzite in overturned folds, with axes dipping in the direction of the cleavage. At left is a quartz vein in the cleavage.
Scale, 4 inches.
BULLETIN NO. 275 PL. V

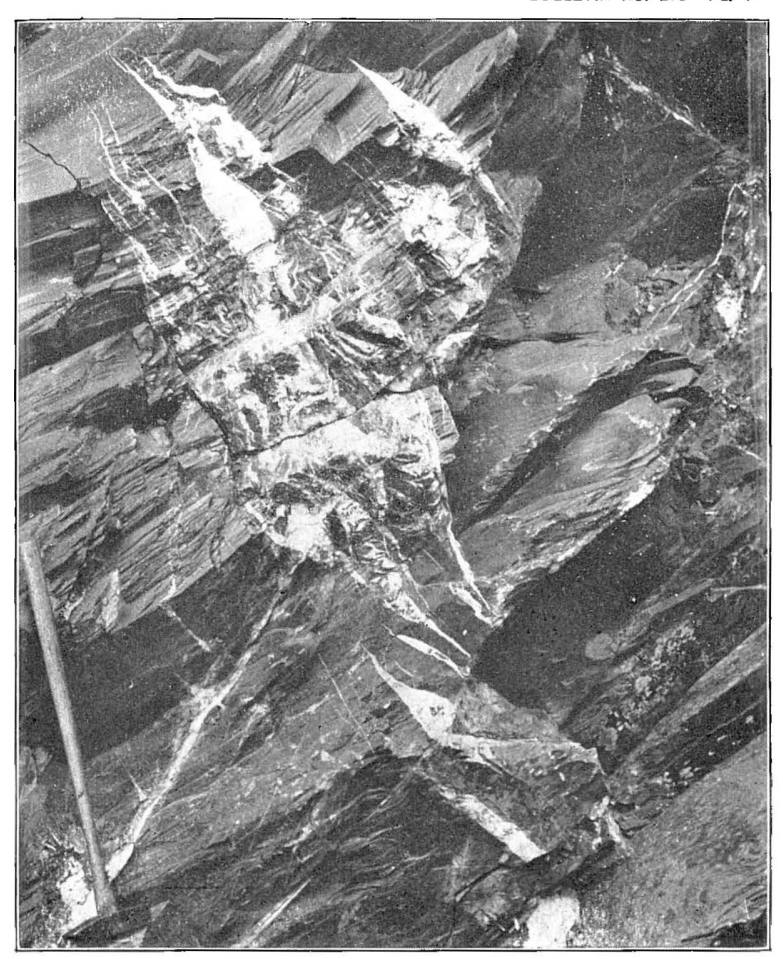

B. QUARTZ VEINS IN SLATE.

Quartz vein of segregation crossing the cleavage of greenish slate at Jamesville, N. Y. Sledge handie is 30 inches. 

His figure is here repeated (see fig. 1 ) with the construction added. $a$

The gist of this is that if we knew the dip of the hard beds on either side of a bed of slate we could foretell the cleavage dip of the slate. This, however, would be applicable only where no secondary disturbance of sufficient force to disturb the relations had occurred.

Relations of cleavage to axes of folds.-Some pre-Cambrian and Paleozoic schist masses have two transverse systems of folding which within limited areas interfere with one another; both systems are also intersected by a cleavage with a constant strike different from that of each. $b$ Where only one system of folding occurs the strike of the cleavage is not necessarily parallel to that of the bedding. In such a case the cleavage is attributed to a change in the direction of the pressure. $c$

The cleavage planes of the slate rocks of North Wales are always parallel to the main direction of the great anticlinal axes, but are not affected by the small undulations or contortions of these lines. The strike of the cleavage in a district is far more constant and regular than the strike of the beds.d

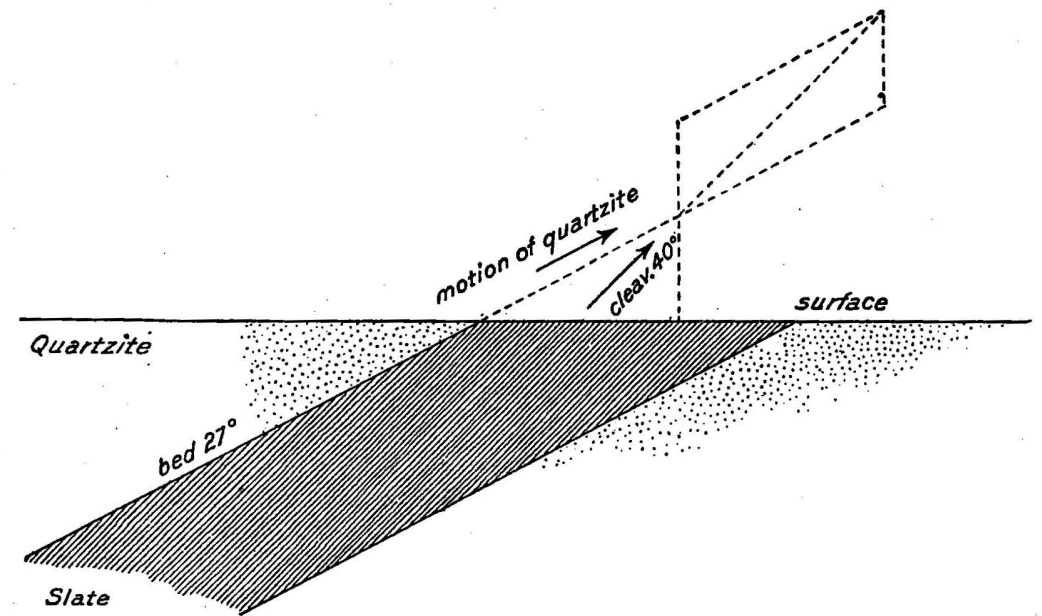

Fig. 1.-Diagram from Gosselet showing relations of cleavage of slate to dip of inclosing hard beds.

To these facts should be added this-that in the case of a pitching fold the cleavage, although parallel to the axis of the fold, must necessarily intersect the strikes of the sides of the fold. Phillips gives a section from Sedgwick, $e$ which he calls a local exception, in which the cleavage planes, while coinciding in strike with that of the anticline which they traverse, incline on either side of it toward its axis. Rogers $f$ describes a case of this fan-like cleavage in an anticline. Such a structure could be produced by secondary movement creating an anticline in horizontal beds already possessing a vertical cleavage, and in the synclinal part of the fold the fan structure would radiate downward.

Sorby figures from Ilfracombe, North Devon, $g$ a small, highly plicated bed of coarsegrained light-colored sandy slate traversing a mass of vertically cleft shaly slate. The gritty beds show a coarse and imperfect fan-like cleavage which curves slightly around the anticlines into the synclines. Here the fan structure seems to be due in part, at least, to the deflection of the cleavage by the coarser material, and there is no need of supposing a secondary movement. The fine and more plastic material has developed a vertical cleavage which in the coarser has become rudely fan like.

$a$ Gosselet, Les schistes de Fumay, pp. 68, 69, fig. 5.

b Loretz, Ueber Schieferung, pp. 69-70.

c Ibid., pp. 83,84 .

d Sharpe and Phillips, Contrib. to Geology of North Wales: Quart. Jour. Geol. Soc. London, vol. 2 , 1846.

$e$ Report on cleavage, p. 374

$f$ Geol. Surv. Pa., vol. 2, part 2, p. 903, fig. 715 .

$g$ On the origin of slaty cleavage, p. 138 . 
Effect of frost on cleavage.-As all slate quarrymen know, repeated freezing and thawing is disastrous to the cleavability of roofing slates. The material must be splic fresh from the quarry. In order to ascertain, if possible, what difference in microscopic structure freezing and thawing produced this experiment was tried: A specimen was obtained from the quarry early in the winter fresh and unfrozen, and was kept moist in a moderate temperature until severe weather set in. It was then broken into two equal parts, one of which was kept moist indoors, the other exposed on the sill of a north window for a week, during which the temperature went down to $10^{\circ}$ below zero $\mathrm{F}$. This part was then thawed out over a furnace register. Both frozen and unfrozen pieces were after some accidental delay sliced and examined microscopically. The whole texture of the frozen slate was found to be perceptibly closer than that of the unfrozen. The test would have been more satisfactory had the thin sections been made at once. The loss from freezing and thawing is so considerable that means to recover it have been sought, and a process has recently been patented for restoring the fissility of slate by the use of liquid air. $a$

Curvature of the cleavage.-As far back as 1839 De la Beche called attention to the curvature of .cleavage planes when approaching a bedding plane. $b$ Baur in 1846 observed S-like cleavage foliation in Germany, and describes certain slates which were so much curved as to be fit for use only on the roofs of towers, but he does not explain whether this curvature was parallel or transverse to the bedding. $c$ John Phillips, in his British Association Report, ascribed these curvatures to the differing density of the beds. $d$ Harker in some cases attributes it to a gradual change in the texture of the beds. $e$ In other cases a secondary motion is called in to explain it. $f$ Curvature of the cleavage is not uncommon in the Lehigh and Northampton County quarries in Pennsylvania, where it is plainly not dependent upon change of texture (see pp. 76, 83). Slates from the beds so affected are also used for roofing towers.

Phillips $g$ gives a figure, the original authorship of which is not mentioned, representing the cleavage surface of a piece of slate in which gently plicated ribbons are shown. A normal fault crosses the piece diagonally, displacing the beds. The cleavage surface also shows the "flexuous" lines of a third foliation oblique to the cleavage. Finally two small calcite veins cross the primary cleavage, the plicated bedding, the plicated secondary cleavage, and also the fault plane. The specimen thus bears traces of at least five, if not six, motions:

\section{SLIP CLEAVAGE ("FALSE CLEAVAGE.")}

Several writers-Sedgwick, $h$ Phillips, $i$ De la Beche, $j$ Zirkel, $k$.Loretz $l$-describe a striation or an extremely fine plication that appears on the cleavage surfaces of some slates: This is the "bate" or "false cleavage" of quarrymen. Two sys-

\footnotetext{
a By W. A. McLaughlin, Delta, Pa.
}

$b$ Report on the Geology of Cornwall, Devon, and West Somerset, p. 620, fig. 31, London, 1839.

$c$ Ueber die Lagerung der Dachschiefer, etc., pp. 392, 393, fig. 9. (For full titles of works cited see Bibliography, pp. 138-145.)

dOp. cit., p. 384, fig. 23. See also Jukes: Quart. Jour. Genl. Soc., vol. 22, p. 359, 1866. That the angle and amount of cleavage change with the density of the rock was shown by Phillips in 1828 . See also Harkness, op. cit., 1855.

$e$ On slaty cleavage, etc.

$f$ Hughes, T. M., quoted in Lyell's Students' Elements, 7 th ed., pp. 53, 573, fig. 625, 1871.

$g$ Report on the Geology of Cornwall, etc., p. 372, fig. 2 .

$h$ "While my first observations on cleavage planes were made during long bygone years in Cumberland, I had hardly noticed the phenomenon of a second cleavage plane; but on many occasions I have subsequently collected, from various parts of England, a considerable and unpublished mass of materials in illustration of this second plane. The second cleavage plane is generally inclined at a great angle to the first plane. Most beautiful examples of this double structure were seen in 1839 by Sir R. Murchison and myself in the quarries of the Ardennes, where the fine, glossy surfaces of the slates are frequently marked by the parallel striæ of second cleavage, and the economical value of the slates is sometimes much deteriorated by the second plane. By a powerful reflected sunlight I have frequently been able to trace these striæ of a second cleavage on the surface of the Bangor slates which have been brought to Cambridge." Synopsis Classif. British Paleozoic Rocks, p. Xxxv; London 1855. Also, by same author, Trans. Geol. Soc. 1840, ․ 655 .

$i$ On a group of slate rocks, 1829, p. 1 .

$j$ Geol. Observer, second ed., 1853, p. 588 , fig. 239 .

$k$ Lehrbuch, 1894 , pp. 307,308 .

$l$ Ueber Transversalschieferung, pp. 263, 264. Spurr, J. E., describes slates in Minnesota with two and three cleavages and bedding: Am. Jour. Sci., 3 d ser., vol. 48, p. 159, 1894. 
tems of such lines or plications may occur in the same slate. These are due to a secondary and tertiary cleavage, a slip cleavage developed upon the primary slaty cleavage. This consists simply of very minute plications which usually result in microscopic slippages or faults along which the slate easily breaks. This structure may show itself where slaty cleavage alone is visible or in the bedding also (see Pls. VI and XI, $A$ ). There is a readjustment of the slaty cleavage and the bedding foliation with reference to the new pressure instead of a rearrangement of all the particles as in slaty cleavage. The presence of "false cleavage" can be detected microscopically in a piece a half-inch square as certainly as from tests applied to pieces of commercial size. The specimen shown in Pl. VI came from a quarry which proved a failure on account of this structure, but it was not detected until after the expenditure of much money. The Arizona slate, described on page 51, shows two slip cleavages crossing one another, as well as both bedding and slaty cleavage.

False cleavage has received in recent years a variety of technical names: Close-joint cleavage, strain-slip cleavage, Ausweichungs-clivage, fissility, fracture cleavage. Science is not advanced by the mere multiplication of technical terms. The term "fissility," being a synnnym of Latin derivation for cleavability of Anglo-Saxon origin, is likely to be misleading. "Close-joint" and "fracture cleavage" are objectionable becaus" they may be applied to jointing. The term "slip cleavage" has brevity and definiteness in its favor, as well as priority over the last two. Slip cleavage is a common feature in schist and is particularly characteristic of the Taconic region in. western Massachusetts, Vermont, and eastern New York, where it seems to be due to a continued, if not, in some instances at least, a secondary, crustal movement consequent upon the first metamorphism. Good illustrations of slip cleavage will be found in the following publications of the United States Geological Survey: Monograph XXIII(1894), figs. 44, 45, 46, 53, 56; Thirteenth Annual Report (1894), p. 319, fig. 25; Fourteenth Annual Report (1895), p. 537, fig. 57; Sixteenth Annual Report, part1 (1896), figs. 89, 96, 97. A careful study of these microscopic drawings and photographs will show that in all cases these minute faults along which more or less slippage has occurred are the necessary result of the lateral shortening of the rock mass by plication. This plication was as much due to a lateral compression as was the major folding of the Appalachian system. Slip cleavage should therefore not be confounded with two intersecting systems of fractures (jointing on a small scale), the strike of neither of which would be at right angles to the direction of strain but diagonal to it or to a single system of such fractures which might be the result of stretching. The same pressure which produced slip cleavage in buried masses of micaceous matter (slate and schist) may have produced fractures at the surface; but where both schist and a rigid, vitreous rock like quartzite have (in contact) been subjected to the same pressure, in the Taconic region, both have usually been folded, the schist in smaller folds, the quartzite in larger ones, but slip cleavage has been confined to the schist, as shown in fig. 25 of Thirteenth Annual Report, already referred to.

The faults or fractures in slip cleavage belong strictly to the process of "rock flowage" and not to that of "rock fracture." As Heim put it: "By real cleavage is always to be understood a cleavability of the material pervading the entire mass and visible in each little fragment. . . ." a

\section{THE GRAIN.}

Sharpe's explanation for slates splitting more readily along the "grain" than across it is that the mineral particles lie with their flat surfaces parallel to the cleavage and their longer axes in the direction of the cleavage dip. A fracture across the cleavage and parallel to the dip is parallel to the longer sides of the particles, whereas one parallel to the strike of the cleavage is across both longer axes and sides. $b$ 


\section{PLATE VI.}

\section{THIN SECTIONS OF ROOFING SLATE WITH SLIP CLEAVAGE ("FALSE CLEAVAGE").}

(A) Microscopic view of a thin section of purple Cambrian roofing slate from an old quarry three-fourths of a mile south of Fair Haven, Vt., showing slip or "false" cleavage originating in minute wrinkles. Section transverse to both cleavages. Enlargement, 55 diameters.

(B) Microscopic view of a thin section of green Cambrian roofing slate from the Huckleberry Hill quarry, 2 miles southeast of West Pawlet, Vt., showing slip or "false" cleavage. Section transverse to both cleavages. Enlargement, 55 diameters. The black spots are pyrite. This figure represents a small part of the dark band shown in Fig. C.

(C) Microscopic view of the same thin section, entire, showing alternation of fine and coarse beds, some of which are pyritiferous, and only in one of which is the false cleavage pronounced. Enlargement, 4 diameters. 


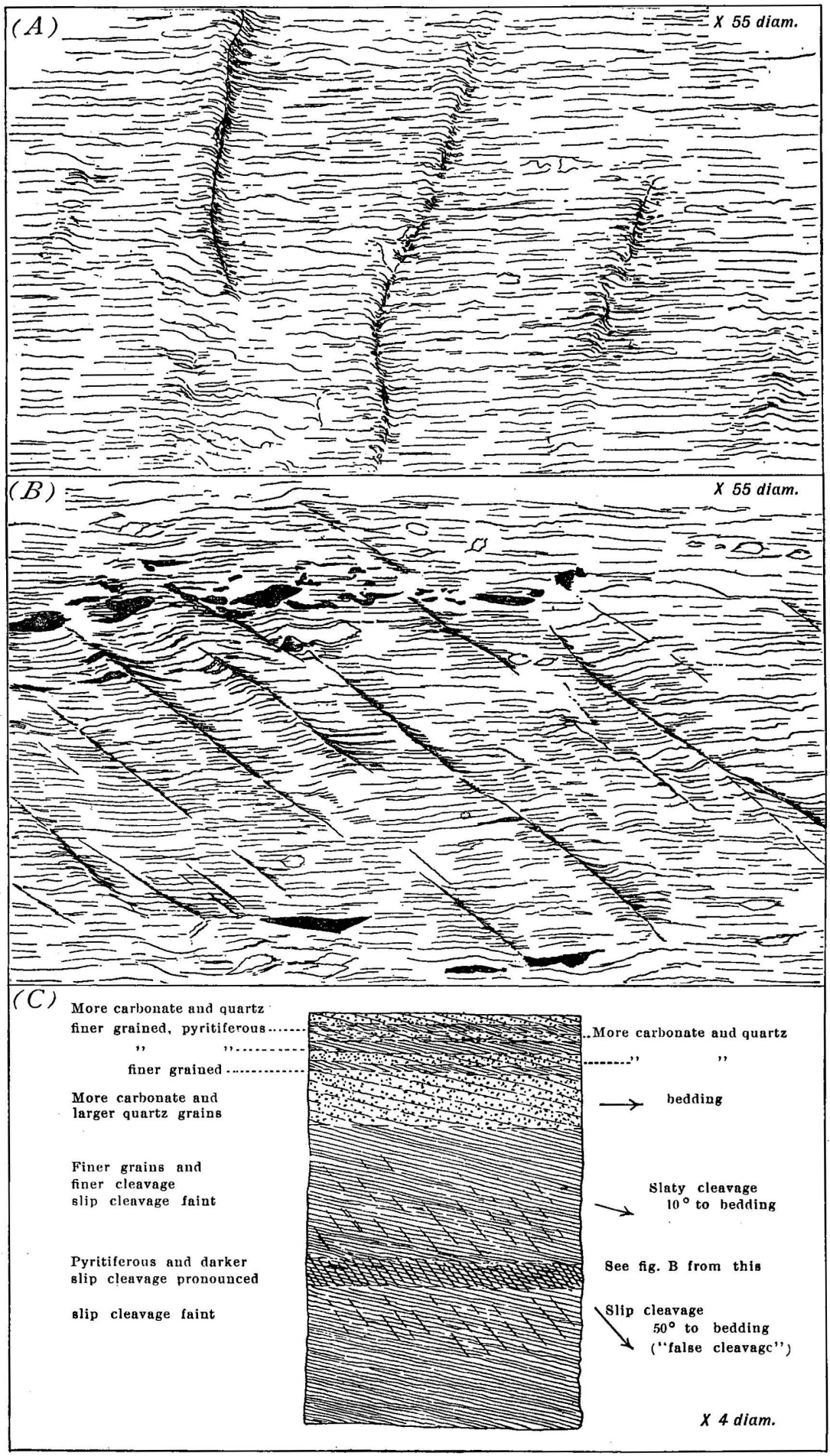



Renard states that the scales of chlorite lie perpendicular to the cleavage, i. e., about in the direction of the grain. $a$ Jannetaz's experiments in reproducing grain have already been referred to (p. 8 ), $b$ and his experiments showing that the direction of the grain is that of the greatest elasticity are given on page 45 .

Daubree, in one of his experiments, produces cleavage in the direction of pressure and motion-which is the relation of grain to pressure. $c$ It seems, therefore, that besides the cause assigned to grain by Sharpe there is the formation of exceedingly obscure vertical divisional planes in the direction of the pressure and the crystallization of secondary minerals along these planes. $d$ The variation of the strike of the grain from the direction of the cleavage dip at Rimogne (Ardennes) is from 1 to $20^{\circ}$. At Fumay, in the same region, that variation is $6^{\circ} . e$ At Rimogne the strike of the grain bisects the acute angle formed by two sets of joints. In some of the Ardennes slates plates of hematite lie in the "grain" and indicate its direction.f Watrin states that as the longer axes of distorted octahedra of magnetite all lie in the direction of the grain in some of the Ardennes slates, their combined magnetism gives a polarity to the slate in the direction of the grain and enables the quarrymen to ascertain its direction by the magnetic needle. A like arrangement of lenses and distorted cubes of pyrite characterizes the slate at Northfield, Vt. (see p. 91), and of folia of muscovite in certain slates near New Canton, Va.

The same feature is occasionally seen in schists. Thus scales of biotite in a schist in Beekman and Pawling, Dutchess County, N. Y., and actinolite crystals in schist in Hubbardton, Vt., have their axes in any direction, but their flat sides transverse to bedding and cleavage.

The "grain" showsitself in a more or less obscure striation of the cleavage surface in a direction nearly parallel to the cleavage dip and sometimes to the dip joints.

In several of the Maine quarries the grain is abnormally nearly horizontal, while the bedding is steeply inclined. As the strike of the grain is about the same as the direction of the pressure which produced the cleavage the logical inference seems to be that the folds at these quarries, if reconstructed, would be found to have a nearly vertical pitch, and this would have to be attributed to a secondary movement. The workmen at these quarries speak of the slate as being "on end." The slate blocks are broken along the grain to reduce them to workable proportions, and as the grain is the direction of weakness roofing slates are always cut with their long sides parallel to the grain, but in some localities there is hardly any grain.

In making thin sections for the microscopic studies of the writer for this bulletin fresh specimens were obtained from the quarries with the grain direction marked on them by the foremen. Thin sections were then prepared transverse to the cleavage and parallel to the grain and also at right angles to it. Where any difference is noticeable between the two sets it consists in the presence of large flakes of chlorite with their flat sides lying in the grain direction or in the longer axes of lenses and crystals lying also in that direction, and, where the sections are very thin indeed, in many small scales of muscovite being similarly oriented. Where the matrix is very micaceous and not obscured by carbonate or other minerals, sections parallel to the grain polarize more brilliantly than those across it.

\section{JOIN'TS.}

Nature of joints.-Joints are simply ruptures of continuity due to various strains. Exceptionally, later movements may cause slippage along joint planes and result in polishing the joint faces (slickensides). The usual character of joint planes, how-

$a$ Renard, op. cit., vol. 3, p. 235.

$b$ See Jannetaz, Mémoire sur les clivages des roches (schistosité, longrain), et sur leur reproduction: Bull. Soc. Géol. France, 3d Ser., vol. 12, p. 211, 1883-84.

c Daubrée, Etudes synthétiques, etc., p. 422 . (For full titles to works'cited see Bibliography, p. 138.)

$d$ Rosenbusch figures biotite scales transverse to cleavage: Elemente der Gesteinslehre, fig. 73 (p. 432 ), p. 437 .

e Renard, op. cit., vol. 3, p. 3.

$f$ Daubr'se, op. cit., p. 336 . 
ever, points to a sudden rupture of large masses of rock affected in all its parts by one and the same mechanical expression of energy. $a$

Sedgwick termed the three commoner kinds of joints occurring in slate regions strike joints (joints parallel to the strike), dip joints (joints parallel to the direction of the dip), and diagonal joints (joints diagonal to strike and dip), terms which ought to be ever kept in use."

To these should be added horizontal joints ("bottom" or "flat joints") which in some slate regions are of much economic importance.

Rogers called attention to the parallelism of joints to dikes in Pennsylvania, a parallelism previously observed in England. $c$

This is so true in western Vermont that the proximity and course of a dike can be foretold by the prevalence of certain diagonal joints. Joints are sometimes open and filled with vein matter and more frequently, when scarcely parted, have their sides coated with crystals of chlorite, calcite, gypsum, pyrite, barite, anatase, etc.

Curred joints. - In exceptional instances joint planes undulate like bedding planes across both bedding and cleavage (see Pl. XVIII). This is attributed, in the Pennsylvania slate region, at least, to a secondary crustal movement. The flat joint near the surface of the Peach Bottom slate belt, with its mass of crushed slate, is probably also of secondary origin. $d$

At Foulk Jones \& Sons' quarry at Slate Hill, 2 miles northeast of Delta, Pa., such a curvature in jointing occurs as to have produced a conical structure 20 to 30 feet high and 15 feet in diameter at the base. In view of the peculiar curvature of fractures across the cleavage of slate resulting from the use of explosives such conical forms may also be the result of shock.

Plicated joints.-In the quarry just referred to a vertical dip joint filled with quartz three-twentieths of an inch thick is in plications from one-fourth to one-half inch wide. These plications may have been due to the zigzag course of the original fracture. Some finely plicated jointing has, however, a different history. Near the extreme north end of the western Vermont slate belt (more exactly, one-fourth mile north of the northwest end of Hincum Pond, in Sudbury, Rutland County) there is a gray slate with a micaceous matrix in which bedding is clearly indicated by the alternation of small carbonaceous beds with noncarbonaceous ones, and also by minute beds with quartz grains up to one-tenth $\mathrm{mm}$. in diameter alternating with beds without any. All of these beds are crossed at an angle of $40^{\circ}$ by slaty cleavage, and both bedding and cleavage are crossed by joints which in places are plicated, measuring an inch from crest to crest, but they are plicated in two directions. In some parts of the rock these joints are only one-fourth inch apart and are parted from one-tenth to one-fifth inch, the openings being filled with banded veins of quartz and fibrous calcite. The solution of these veins at the surface has left a series of plicated gaping joints crossing both bedding foliation and slaty cleavage. Under the microscope these joint veins are seen to consist on either side of a border of vein quartz, followed similarly by two bands of calcite fibers, then two bands of quartz, followed by a central band of gently curving calcite fibers with a central parting containing a little quartz at intervals. The slate between these joints also shows a slip cleavage crossing bedding and slaty cleavage in the general direction of the joints, but not plicated. The history of this slate thus appears to be: (1) The folding of a mass of marine sediments of alternating composition and the formation of slaty cleavage at an angle of $40^{\circ}$ to the folded beds; (2) compression along the strike

a Loretz: Über Schieferung, pp. 98-100.

bA Synopsis of Classification of the British Paleozoic Rocks, by Adam Sedgwick; London, 1885, p. 35 .

$c$ H. D. Rogers, Geology of Pennsylvania, vol. 2, pt. 2, p. 912, fig. 718, joints in red shale parallel to dike; also fig. 719 , joints in argillaceous sandstone; 1858 .

$d$ See on curved joint planes in the Peach Bottom district: Edward B. Mathews, Maryland Geol. Survey, vol. 2, 1898, p. 223, H1. XXII, fig. 1. 
resulting in slip cleavage; (3) the elongation of the mass along the strike producing open joints; (4) compression, both in the direction of the dip of the slaty cleavage and in a direction at right angles to that, thus plicating the joints in a twofold way; (5) the infiltration of $\mathrm{SiO}_{2}$ and $\mathrm{CaCO}_{3}$ in alternation into the open joints, resulting in banded veins; (6) the solution of the $\mathrm{CaCO}_{3}$ by carbonic and organic acids and the crumbling away of the $\mathrm{SiO}_{2}$ in consequence of exposure by erosion. Such a slate shows what complex structures successive crustal movements may produce in ordinary sediments, as well as how fatal such movements may be to the commercial value of slate. These joints were probably first formed by elongation, and thus are different from ordinary joints.

\section{FAULTS.}

Faults of no great magnitude are common in slate regions. The fault plane is frequently a cleavage or a joint plane. From the shear involved in slaty cleavage reversed faults are more frequent in slate than normal ones. $a$ Minor faults from the western Vermont region are shown in $\mathrm{Pl}$. IV $C, D$. One of these is a normal fault, the part overlying the fault plane having slidden down; the other is a reverse fault, the similar part having been forced up. A microscopic section across the reverse fault shows the sharp bending of the beds at the fault plane, and the deposition of a thickness of one-sixteenth of an inch of vein matter in bands along that plane. This matter consists of chlorite, calcite, and quartz.

Some of the slate flagstones in the village of Granville, N. Y., the exact source of which could not be ascertained, are full of small faults, which come out finely in the rain, and show how much secondary compression there must have been at that locality.

Faulting may occur within a slate mass in two directions at right angels to one another. $b$

The dropping of a block of some superjacent valueless strata into a mass of commercial slate between two fault planes is a possibility that should not be overlooked in slate quarrying.

\section{SHEAR ZONES (HOGBACKS).}

These terms, as well as Knickungsebenen, Querknicke, zones of shearing, apply to one and the same feature. Rosenbusch, $c$ Brögger, $d$ Reusch, $e$ and Turner $f$ describe it from Norway, Saxony, Alsatia, and California. Its occurrence in the slate belt of eastern New York and western Vermont is fully described on pages 31, 44 . These writers explain it as an angular plication, or a series of such plications, due to shearing pressure on somewhat rigid material. In places the pressure was great enough to produce a slight faulting on either side of the defiected portion or zone. Very rarely a cleavage foliation is produced within the zones. Mr. Turner's term abbreviated to shear zone affords a convenient designation, with the understanding, however, that in this sense it applies only to sedimentary rocks.

The term "hogback" is used by coal miners to describe a sharp rise in the floor of a coal seam. The propriety of its application in slate quarries is not so obvious. It is used there to designate peculiar bends or fractures, which consist of two angular bends in opposite directions and near each other, traversing a mass of slate. These

$a$ See Herbert, E. J., Reversed faults in bedded slates. Geol. Mag. N. S. Dec. II, vol. 4, p. 441, 1877. Survey, 1894, Pl. CI., p. 320, fig. 26. Also, in this connection, A faulted slate slab, by J. J. H. Teall: Geol. Mag., Dec. III, vol. 1, PI. I, London, 1884.

c Die Steiger Schiefer, 1877, p. 95.

$d$ Brögger, Die silurischen Etagen 2 u. 3 im Kristiania Gebiet auf Eker, p. 216, fig. 31, Kristiania, 1882.

$e$ Reusch, H., Die fossilienführenden krystallinischen Schiefer von Bergen in Norwegen; German translation by R. Baldauf, pp. 52, 53, fig. 35; and p. 38, fig. 23, Leipzig, 1883.

$f$ Turner, H. W., Further contributions to the geology of the Sierra Nevada: Seventeenth Ann. Rept. U. S. Geol. Survey, p. 662, fig. 22, 1896.

Bull. 275-06-3 


\section{PLATE VII.}

\section{SHEAR-ZONES ("HOGBACKS").}

(A) Diagram of thin section of "sea-green" Cambrian slate from Williams and Edwards' quarry in Wells, Vermont. Enlarged 2 diameters. Section across the cleavage and an incipient "hogback," showing the two bends in opposite directions and developed in but two places into fractures. Secondary fractures at $15^{\circ}$ to cleavage cross the zone. A calcareous strip, possibly a trace of bedding, crosses the cleavage at $45^{\circ}$. All the fractures filled with calcite.

$(B),(C),(D)$ Microscopic drawings from above thin section, enlarged 40 diameters, showing in reversed position the outlines of several of the vertical and diagonal fractures within and at edge of zone.

(E) Diagram from specimen of "hogback," from E. E. Lloyd's sea-green slate quarry, Poultney, Vermont.

$(F)$ Slate from within a fully developed "hogback," showing outline of fracture. Same location as $E$.

$(G)$ Same location as above slate, showing two "hogbacks."

$(H)$ Diagram from specimen of Cambrian slate from Eddy Hill, Fair Haven, Vermont, showing development of "hogbacks." Secondary quartz occurs along the fractures. Reduced one-half.

( $I$ ) Shear-zone in Silurian schist $1 \frac{1}{2}$ miles east of Rupert, Vermont.

$(K)$ Diagram from specimen from top of the Pattern, in Pawlet, Vermont.

$(L)$ Diagram from thin section of Cambrian slate from Eddy Hill, Fair Haven, Vermont, enlarged two diameters, showing one of the main fractures of a "hogback" with diagonal fractures which are filled with quartz, and beside it slip-cleavage. 


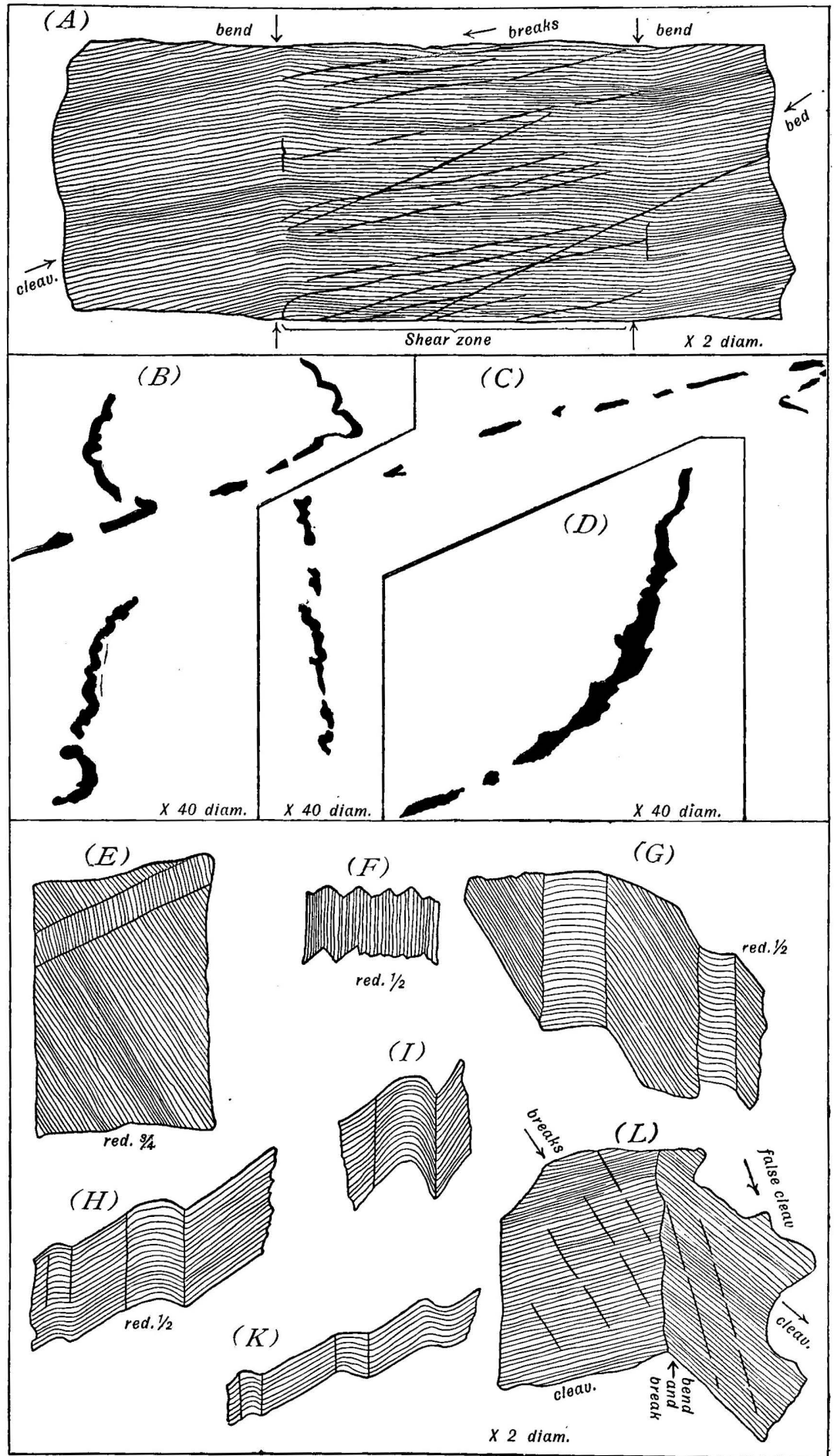

SHEAR ZONES. 

flexures may and often do merge into fractures, and the slate between the two planes of fracture is broken into small fragments. The two bends or fractures may be anywhere from one-sixteenth of an inch to 4 feet apart. At one of the old Middle Granville, N. Y., quarries a slate surface shows within a space of 4 inches four " hogbacks" varying from one-sixteenth to one-fourth inch in width. Another has six in a space of 6 inches. At one of the Arvonia, Va., quarries a mass 5 feet thick is traversed by numerous shear zones. As they generally traverse the cleavage diagonally, the blocks of slate adjacent to them come out in triangular form, and thus occasion much waste. The strike of some of the shear zones in western Vermont is parallel to that of several of the dikes, and both may have been formed under the same stress. Figs. E, G, I, on Pl. XXIII, and figs. L, U, and V, on Pl. XXIV, show the relations of "hogbacks" at several quarries. Fig. A, on Pl. VII, shows the microscopic structure of the "hogback" of Fig.V, Pl. XXIV. The section was made where the bends had not as yet developed into complete fractures. The entire width of the "hogback" is nine-tenths of an inch. Between the two sides is a system of cracks crossing the cleavage at an angle of $15^{\circ}$; another system crosses the cleavage at $25^{\circ}$ and extends beyond the side. This may be the original bedding. Both of these systems of cracks are filled with secondary calcite. Another set, likewise filled with it, crosses the cleavage bere and there about at right angles, but in zigzag (see figs. B, C, D, Pl. VIf). These, farther on in the quarry, become continuous fractures. The secondary fractures within the zone probably result eventually in breaking up the slate, as it occurs usually in fragments within a fully developed shear zone. The observations at this quarry were: Strike of bed N. \pm , dip $30^{\circ}$ E.; strike of cleavage N. \pm , dip $42^{\circ}$ to $45^{\circ} \mathrm{E}$.; strike of shear zone N. $35^{\circ}$ to $40^{\circ} \mathrm{E}$., dip $65^{\circ} \mathrm{NW}$. In this case the strike of the shear zone corresponds to that of the diagonal joints of the region and of a number of the dikes. Figs. $\mathrm{E}$ to L, on PI. VII, illustrate the development of a shear zone still further. In fig. $\mathrm{L}$ the diagonal fractures are filled with quartz, and a slip cleavage (false cleavage) also occurs. Other observations of "hogbacks" are given on the quarry tables, pp. 102, 103.

\section{CLEAVAGE BANDS.}

While characteristic of slate regions, cleavage bands do not occur or have not yet been reported in commercial slate. They would be quite as objectionable as are shear zones.

Pl. XI, $B$, is from a photograph taken at a locality in Rupert, Vt., found by Mr. L. M. Prindle. Cleavage banding is of frequent occurence in the Vermont and New York slate belt and in the schist mass east of it, although not always as well shown as at this point. It resembles the shear-zone structure just described, but presents further stages. In Pl. XI, $B$, the rock is divided into alternate bands of hard, uncleft quartzose shale and of bands of very finely cleft shale. The bedding zigzags across both bands. The material of both bands was originally identical. The present differences are the result of a difference in the amount of motion-i. e., of slip cleavagealong alternating strips of rock and of the consequent difference in resistance to erosion. There is also a difference in color, some infiltration of limonite having taken place along the more highly cleft bands.

A similar structure in purple slate is shown in fig. 2, but here the bands themselves have slipped. $a$ Small beds of green slate indicate the course of the stratification and show the amount of slippage suffered by the bands.

In the Poultney River, about a mile east of East Poultney, certain hard, bright green and purple slates near the schist mass show the cleavage banding well. In breaking up such a rock the denser uncleft parts come out in slab-like blocks, the larger surfaces of which lie transverse to the bedding. 
Doctor Becker $a$ explains this structure by the alternate interference and coincidence of waves of vibration produced by shock. When the waves of vibration coming from opposite directions coincide, cleavage fractures-i. e., planes of slip cleavage-will be numerous.

Professor Van Hise regards such structures simply as the result of the concentration or sparseness of slip cleavage. $b$

In the ledge figured in Pl. XI, $B$, there are between 360 and 530 such planes to the inch in the cleft bands. The hard bands in the same ledge show as many fractures, but they are discontinuous or merely incipient. Both hard and soft bands consist of stratified shale made up of quartz fragments, muscovite and chlorite scales, etc., but in the soft ones the pressure has in places brought about sufficient alignment of the muscovite to produce aggregate polarization', not in the direction of the slip cleavage but in that of the bedding. There has also been a formation of sericite along the slip-cleavage planes, and thus the rock is becoming a schist.

In a piece of sericite schist from the mass east of Rupert the rock consists of alternating strips with and without slip cleavage, those without being wider. The slipcleavage planes meander about and run into each other, though having a general parallelism. The plication is much more intense and irregular in the cleft strips and also appears to be more sericitic there.

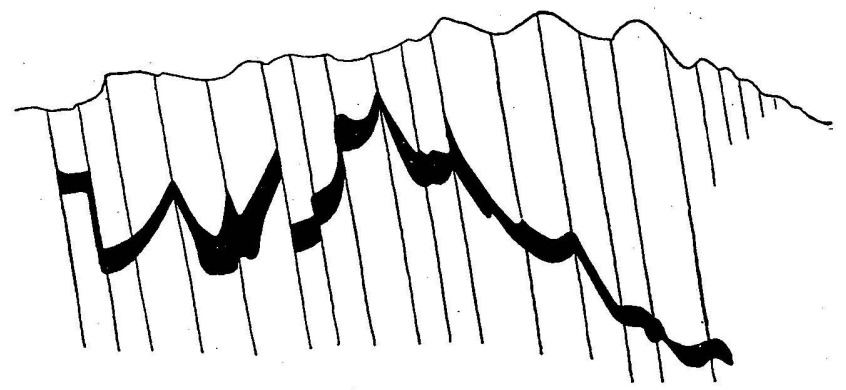

FIG. 2.-Cleavage banding showing slippage of bands; brook in Gorham, Poultney, Vt.

In all these cases the fractures are the result of the plications.

It seems probable that the shear zones represent but a variation of the process involved in the cleavage bands. The force bent and crushed the slate in the bands instead of producing very numerous planes of slip cleavage within them.

\section{VEINS.}

Quartz veins or "flints," as the quarrymen call them, are a striking feature of slate as well as a cause of perplexity in quarrying. They appear at the most unexpected points, frequently ramify very irregularly, and disappear as suddenly. Pl. V, $B$, from the old quarries at Jamesville, N. Y., shows a good type of such veins of

$a$ Finite homogeneous strain, flow, and rupture of rocks: Bull. Geol. Soc. Am., Vol. IV, Jan., 1895. On page 16 he says: "Thus there seems sufticient reason to believe that a pressure very rapidly applied, producing primary ruptures attended by shock, will be immediately followed by secondary ruptures in the same direction as the others at intervals dependent upon the wave length of the impulse. In much the same way a high explosive shatters a rock far more than black powder. A phenomenon of which no explanation has been offered in this paper is that of thick slates and of those flags which are to be considered as very thick slates. These, though cleavable in a certain thinness, are not capable of further splitting. Such rocks indicate a flow which is not uniformly distributed through the mass, but on the contrary passes through maxima at intervals corresponding to the thickness of a slate or flag. It is possible that at the inception of strain such masses were in a state of tremor so intense that the interference of waves determined surfaces along which flow began. These surfaces would be weakened by the flow, and further strain would be distributed among them rather than over the intervening solid sheets. Effects of a similar kind are produced on a pile of sheets of paper, such as 'library slips,' resting on an inclined cloth-covered table which is jarred by rapid blows."

b Sixteenth Ann. Rept. U. S. Geol. Survey, pt. 1; Principles of North Am. pre-Cambrian Geology, 1896, pp. 662-664. 
segregation. In some cases there is a rough parallelism in them. They may occur partly in the bedding and partly in the cleavage, or may cross both bedding and cleavage, their general dip being roughly at right angles to that of the cleavage, and their strike probably not very different from that of cleavage and bedding. Such veins may be several hundred feet long and several feet thick, or may form lenses several feet in length. At Benson, Vt., and Ijamsville, Md., small joint veins of fibrous calcite form series of gashes "en échelon." The fibers or prisms lie transverse to the course of the vein. Daubrée regards such veins as due to stretching. $a$ That the material of the veins described, of whatever sort, must have come from the adjacent slate itself is evident, and also that it was deposited in solution.

In the cases adduced there is some relation between the foliations of the slate and the course of the veins, but veins do occur which appear to be quite lawless, crossing in every direction, anastomosing, and intersecting one another, and sometimes inclosing fragments of the adjacent slate and constituting the cement of a brecciated area. That the veins are the result of various secondary stresses, producing openings of more or less irregularity, is manifest. Where the stress ceased to operate the vein tapers out; where the stresses were complex the veins are so.

The material which filled the openings thus made is chiefly quartz, frequently "milky" in color, and often finely crystallized in small cavities. With the quartz are often associated chlorite, biotite, calcite, and possibly dolomite. The chlorite sometimes occurs in hexagonal scales, in vermicular aggregations, or in tortuous columns. Some of the smaller veins are banded, presenting alternations of quartz and fibrous calcite, or of quartz and rhombs of calcite, as in the case of those in plicated joints described on page 28. Sometimes the quartz contains cavities measuring from 0.002 to 0.005 millimeter in diameter, partly filled with fluid. Galenite in small particles was found.in veins at the Jamesville, N. Y., quarries.

\section{NODULES.}

In some of the western Vermont quarries very hard nodules, a few inches in diam. eter and of lenticular form, occur along the bedding planes. They consist of a quartzite nucleus containing much calcite and large scales of muscovite surrounded by slaty layers with calcite, quartz, and muscovite scales. Pyrite is disseminated throughout both nucleus and outer zone. Such nodules are evidently of sedimentary origin.

Müller describes concretions of pyrite and quartz in the slate quarries of Thüringen and observes that the slate in their vicinity is of superior quality, containing less pyrite than it does at a distance from the nodules. The explanation is that all the pyrite has congregated in the large nodules instead of being more widely disseminated in small crystals. The nodules are thus of economic advantage. $b$

\section{DIKES.}

Volcanic dikes are not infrequent in slate deposits. Leaving out the very exceptional one described by Mr. Eckel on page 57, dikes are almost as detrimental as veins. They are usually more regular than veins of segregation and, as stated under "Joints," are apt to give warning of their proximity by an abundance of joints parallel to them. For several feet on each side of the dike these joints become very close and are sometimes crossed by an equally numerous set of horizontal ones, thus breaking up the slate into small blocks. At Arvonia, Va., it appears that the quality of the slate a little beyond the dike is better than it is farther away, so that a dike traversing a slate deposit is not necessarily without economic value. 


\section{GEOLOGICAL RELATIONS OF SLATE.}

In view of the origin and structure of the marine sedimentary slates it is evident that such slate deposits are to be looked for along the borders of or in proximity to granitic land masses where the dominant pressure has come mainly from one direction and where it has not been sufficiently intense to result in extreme metamorphism. The Maine slate belt lies not far south of a granitic area. Two of the Vermont slate belts lie but a few miles west of the Green Mountain granitic axis and two others east of it. In eastern Pennsylvania, West Virginia, and Maryland the slates lie not far northwest of a granitic area, and the Virginia slate lies not many miles southeast of one.

From the facts brought out in considering the structure of slate it is also evident that slate belts generally bear evidence of more than one crustal movement. Along the entire Appalachians, where at least two major mountain-making movements occurred-the Ordovician and the Carboniferous-and where the slates are mostly of Cambrian or Ordovician age, they must needs show the effect of at least one disturbance of the slaty cleavage.

Where, as in western Vermont and eastern New York, slates of two geological periods occur in proximity, and where one is even superposed on another, the question of their mutual relations becomes of economic and scientific importance. $a$ There was here a crustal movement at the close of Lower Cambrian time which resulted in the cleavage of the Lower Cambrian sediments and their emergence. They were afterwards, in places submerged and received Ordovician deposits, which, at the close of Ordovician time, were folded and also received a slaty cleavage. Moreover, the folds of both periods are overturned.

\section{CHEMISTRY OF SLATE.}

\section{CHEMICAL COMPOSITION.}

Comparatively few complete chemical analyses of roofing slates have found their way into scientific literature. Several of the rare elements are usually omitted. FeO and $\mathrm{Fe}_{2} \mathrm{O}_{3}$ are not distinguished, nor $\mathrm{CaO}$ and $\mathrm{CO}_{2}$, so that several of the percentages are more or less misleading. Fourteen selected analyses, all but one from European sources, are here given for reference:

Selected analyses of roofing slates.

\begin{tabular}{|c|c|c|c|c|c|c|c|c|c|c|c|c|c|c|}
\hline & I. & II. & III. & IV. & v. & VI. & VII. & VIII. & IX. & $\mathrm{X}$. & XI. & XII. & XIII. & XIV. \\
\hline $\mathrm{SiO}_{2}$ (silica) & $|58.30|$ & 61.57 & $65.63 \mid$ & 61.43 & 67.56 & 59.35 & 55.880 & 55.06 & 60.68 & 60.17 & 56.71 & 56.92 & 57.23 & 63.06 \\
\hline $\begin{array}{l}\mathrm{TiO}_{2}(\text { titanium di- } \\
\text { oxide }) \ldots \ldots \ldots \ldots . . . . .\end{array}$ & .23 & 1.31 & .94 & .73 & & 1. 00 & 1. 270 & $\cdots$ & .59 & 1.15 & .70 & .90 & .89 & \\
\hline $\mathrm{Al}_{2} \mathrm{O}_{3}$ (alumina) $\ldots$. & 21.89 & 19.22 & 20.20 & 19.10 & 12.23 & 13.56 & 21.849 & 22.55 & 21.20 & 18.89 & 14.43 & 16.41 & 20.43 & 18.03 \\
\hline $\mathrm{Fe}_{2} \mathrm{O}_{3}$ (ferric oxide) & 7.05 & 6.68 & 2.72 & 4.81 & 2.87 & 1.10 & 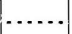 & 1.97 & 5.68 & 6.17 & 1.98 & .53 & 1.33 & 2.24 \\
\hline $\mathrm{FeO}$ (ferrous oxide) & 2.57 & 1.20 & .85 & 3.12 & o.. 99 & 4.75 & 9.033 & 5.96 & .46 & .95 & 3.65 & 3. 52 & 5.64 & 4.07 \\
\hline $\mathrm{CaO}$ (lime)... & .39 & .22 & .19 & .31 & .27 & 5.20 & .155 & 1.30 & 1.71 & 1.75 & 3.83 & 2.94 & 1.54 & .81 \\
\hline $\mathrm{BaO}$ & & & & & $\cdots$ & .... & & $\cdots$ & & .04 & .04 & .03 & .02 & . \\
\hline MgO (magnesia) ... & 1.09 & 2.00 & 1.54 & 2.29 & 3.03 & 3.60 & 1.495 & 2.92 & .88 & 1.85 & 3.47 & 3.14 & 2.49 & 2.21 \\
\hline $\mathrm{K}_{2} \mathrm{O}$ (potassa) ....... & 2.45 & 3.63 & 3.81 & 3.24 & 1.76 & 1.77 & 3.640 & 3.82 & 3.64 & 2.76 & 2.61 & 3.27 & 2.39 & 3.07 \\
\hline $\mathrm{Na}_{2} \mathrm{O}($ soda $) .. . . . .$. & 1.18 & .93 & .71 & .83 & 1.28 & 1. 48 & .460 & 2.17 & 2.09 & 1.39 & 2.59 & 1.47 & 3.97 & 1.51 \\
\hline $\begin{array}{c}\mathrm{CO}_{2} \text { (carbon diox- } \\
\text { ide) } \ldots \ldots \ldots \ldots \ldots .\end{array}$ & & & & & & 4.45 & & & & 1.04 & 3.71 & 2.68 & & None \\
\hline (carl & & & & & 3.11 & & 1,7 & & & & 7 & & & \\
\hline
\end{tabular}

$a$ See Am. Jour. Sci., 4th ser., vol. 17, 1904, p. 185, and Bull. U. S. Geol. Survey, No. 242, 1905. 
Selected analyses of roofing slates-Continued.

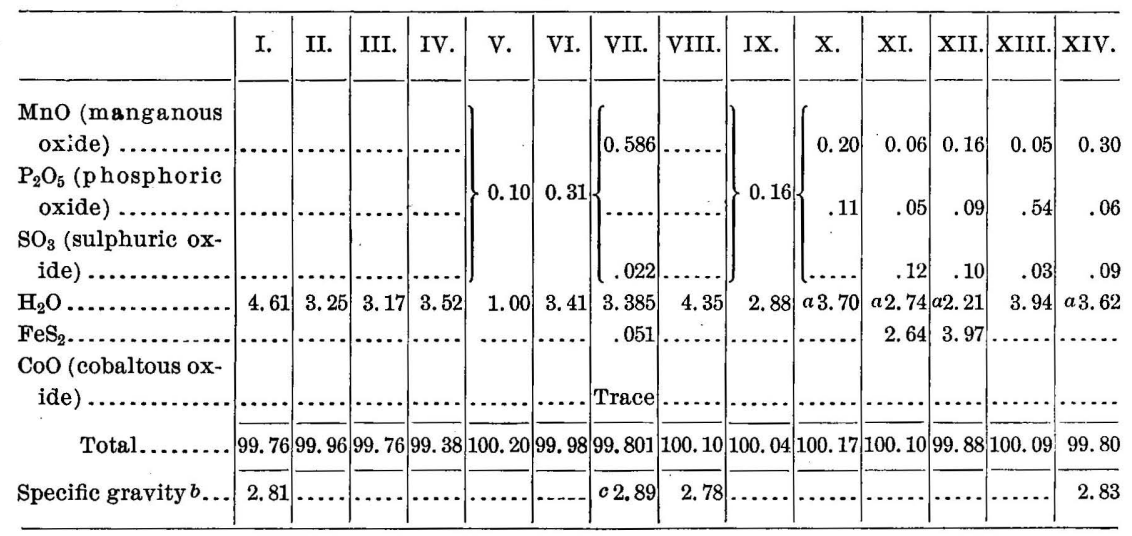

$a$ Combined water.

$\boldsymbol{b}$ The specific gravity of the Festiniog black slates of Wales was determined as 2.751 at the physical laboratory of Williams College in 1899. Since the publication of Doctor Hillebrand's note on New York and Vermont slates, Reade and Holland find as a mean of 13 Welsh slates $\mathrm{Cr}_{2} \mathrm{O}_{3}, 0.003 ; \mathrm{V}_{2} \mathrm{O}_{5}$, $0.032 ; \mathrm{ZrO}_{2}, 0.022$. See Proc. Liv. Geol. Soc. (1900-1901), p. 101, and table.

$c$ Spec. grav. from Merriman.

I. Gray roofing slate, best quality, Delabole, Camelford, Cornwall; two analyses by J. A. Phillips, London, Edinb. and Dublin Phil. Mag., 4th ser., No. 27, pp. 95-96, Feb., 1871.

II. Purple roofing slate, Fumay, Ardennes, northwest France; by A. Renard, Recherches sur la composition et la structure des phyllades ardennais; Bull. Mus. Roy: d'Hist. Nat. de Belgique, V.ol. I, p. $239,1882$.

III. Green roofing slate beds from purple, Fumay, Ardennes, as above.

IV. Blue-gray roofing slate, La Richolle quarry, Rimogne, Ardennes, northwest France; by Klement, pub. by A. Renard, op. cit. supra, p. 233.

V. Roofing slate (probably black, Devonian), Westphalia; by H. von Dechen; Roth. Allgem. und Chem. Geol., II, pp. 586, 587, 1884 . (107.)

VI. Roofing slate (color not given, Devonian), Frankenberg, near Goslar, in Prussia; by A. von Groddeck; Jahrb. pr. Geol. Landesanst, 1885-86; quoted in Roth. Allgemeine Chem. Geol., II, pp. $586,587$.

VII. Black roofing slates ("Peach Bottom") from J. Humphreys Co.'s quarry, half a mile east of Delta, York County, Pennsylvania; by Andrew S. McCreath, in 2d Geol. Surv. Pa., Report of Progress, 1877, Vol. CCC, pp. 269, 270, 1880.

VIII. Bluish roofing slate of Carboniferous age, Mohradorf, near Wigstadl, Austrian Silesia; by Nikolic, in Tschermaks Min. Mitth., 1871, p. 207; quoted by Roth, op. cit. supra, pp. 588-589.

IX. Blue slate, Glyn quarries, Llanberis, Wales; analysis made at Museum of Practical Geology, London, for George Maw, Geol. Mag., London, 1868, vol, 5, p. 123.

X. Reddish roofing slate (best), Alexandra quarry, Moel Tryiaen, North Wales. Anal. by Reade and Holland, Proc. Liverpool Geol. Soc. (1899-1900), 1900. (Ana]. No. 1.)

XI. Very dark banded roofing slate, Llansantfraid, Glyn Ceiriog, near Llangollen, North Wales. Anal. by Reade and Holland, Proc. Liverpool Geol. Soc. (1899-1900), 1900. (Anal. No. 2.)

XII. Very dark roofing slate, Moel Ferna, North Wales. Anal, by Reade and Holland, Proc. Liverpool Geol. Soc. (1899-1900), 1900. (Anal. No. 3.)

XIII. Green roofing slate from quarry between Camlyn and Cemmaes, Anglesey. Anal. by Read ! and Holland, Proc. Liverpool Geol. Soc. (1899-1900), 1900. (Anal. No. 4.)

XIV. Green roofing slate, Velenhelli, Wales. Anal. by Reade and Holland, Proc. Liverpool Geol. Soc. (1900-1901), p. 112. (Anal. No.6.)

The fifteen complete analyses of New York, Vermont, and Pennsylvania roofing slates made by the chemists of the United States Geological Survey and given under the descriptions of those slates are summarized in the following table. Wherever several analyses were made of one kind of slate the average is given. The rarer elements and water below $110^{\circ} \mathrm{C}$. have here been thrown together. 
Summarized analyses of roofing slates from New York, Vermont, and Pennsylvania.

\begin{tabular}{|c|c|c|c|c|c|c|c|c|c|}
\hline & $\begin{array}{c}\text { Sea } \\
\text { green. } \\
\text { (3) } a \\
\text { Vt. }\end{array}$ & $\begin{array}{c}\text { Unfad- } \\
\text { ing } \\
\text { green. } \\
(2) \quad \mathrm{Vt} .\end{array}$ & $\begin{array}{c}\text { Bright } \\
\text { green. } \\
\text { (1) } \\
\text { N.Y. }\end{array}$ & $\begin{array}{c}\text { Varie- } \\
\text { gated } \\
\text { (Eure- } \\
\text { ka).(1) } \\
\text { Vt. }\end{array}$ & $\begin{array}{c}\text { Purple. } \\
(2) \\
\text { Vt. }\end{array}$ & $\begin{array}{l}\text { Red. (4) } \\
\text { N.Y. }\end{array}$ & $\begin{array}{c}\text { Black. } \\
\text { (1) } \\
\text { Vt. }\end{array}$ & $\begin{array}{c}\text { Black. } \\
\text { (1) } \\
\text { Lehigh } \\
\text { Co., Pa. }\end{array}$ & $\begin{array}{l}\text { Gener- } \\
\text { al av- } \\
\text { erage. }\end{array}$ \\
\hline $\mathrm{SiO}_{2}$ (silica) & 63.33 & 59.37 & 67.89 & 60.24 & 61.29 & 63.89 & 59.70 & 56.38 & 61.51 \\
\hline $\mathrm{TiO}_{2}$ (titanium dioxide). & .73 & 1.00 & .49 & .92 & .77 & .52 & .79 & .78 & .75 \\
\hline 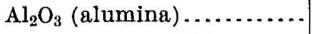 & 14.86 & 18. 51 & 11.03 & 18.46 & 16.24 & 11.80 & 16.98 & 15.27 & 15.39 \\
\hline $\mathrm{Fe}_{2} \mathrm{O}_{3}$ (ferric oxide) $\ldots . .$. & 1.12 & 1.18 & 1.47 & 2.56 & 4.63 & 4.56 & .52 & $b 1.67$ & 2. 21 \\
\hline $\mathrm{FeO}$ (ferrous oxide) .. & 4.93 & 6.69 & 3.81 & 5.18 & 2.62 & 1. 33 & 4.88 & $b 3.23$ & 4.08 \\
\hline $\mathrm{CaO}$ (lime) & 1. 20 & .49 & 1.43 & .33 & .60 & 2.25 & 1.27 & 4.23 & 1.47 \\
\hline MgO (magnesia). & 2.98 & 2.36 & 4.57 & 2.33 & 2.99 & 4.57 & 3.23 & 2.84 & 3.23 \\
\hline otassa) ........... & 4.06 & 3. 78 & 2.82 & 4.09 & 5.27 & 3.95 & 3.77 & 3.51 & 3.90 \\
\hline $\mathrm{Na}_{2} \mathrm{O}$ (soda) ................... & 1.22 & 1.71 & .77 & 1.57 & 1.38 & .50 & 1.35 & 1.30 & 1.22 \\
\hline $\mathrm{CO}_{2}(\mathrm{c} \varepsilon$ & 1.41 & .30 & 1.89 & .08 & .54 & 3.15 & 1.40 & 3.67 & 1.55 \\
\hline $\mathrm{FeS}_{2}$ (pyrite) $\ldots \ldots \ldots \ldots \ldots \ldots$ & .11 & .14 & .04 & .16 & .04 & .02 & 1.18 & 1.72 & .42 \\
\hline $\mathrm{H}_{2} \mathrm{O}$ (water above $110^{\circ}$ C.)... & 3.37 & 4.01 & 3.21 & 3.81 & 3.16 & 2.82 & 3.82 & 4.09 & 3.53 \\
\hline $\mathrm{C}$ (carbon) $\ldots \ldots \ldots \ldots \ldots$ & Trace. & & & & & & .46 & .59 & \\
\hline $\begin{array}{r}\text { Sundry and water below } \\
110^{\circ} \mathrm{C} \ldots \ldots \ldots \ldots \ldots \ldots \ldots\end{array}$ & .69 & .51 & .66 & .39 & .56 & .77 & .70 & 1.11 & .67 \\
\hline Total . & 100.01 & 100.05 & 100.08 & 100.12 & 100.09 & 100.13 & 100.05 & 100.39 & \\
\hline Specific gravity $b$. & 2.776 & 2.795 & 2.717 & 2.805 & 2.806 & 2.796 & 2.774 & 2.783 & 2.783 \\
\hline
\end{tabular}

$a$ Figures in parentheses indicate the number of analyses averaged.

b Approximate.

If analysis $\mathrm{K}^{2}$ of red slate on page 73 be included with the four others, the per cent of $\mathrm{Fe}_{2} \mathrm{O}_{3}$ in the red slates would range from 3.48 to 7.10 per cent and would average 5.08. Comparing, then, the amount of $\mathrm{Fe}_{2} \mathrm{O}_{3}$ in the colored slates we shall find that it steadily increases from the variegated to the purple and to the red, as the microscopic sections show.

On the other hand, there is a decrease of $\mathrm{FeO}$ in passing from the unfading green to the variegated, sea-green, bright green, purple, and red. This decrease corresponds to and is probably consequent on the decrease of chlorite, a hydrous silicate of $\mathrm{MgO}$ and $\mathrm{FeO}$.

There is more lime $(\mathrm{CaO})$ and carbon dioxide $\left(\mathrm{CO}_{2}\right)$ in the Lehigh slate than in any of the others. There is less $\mathrm{CaO}$ and $\mathrm{CO}_{2}$ in the unfading green and in the variegated analyzed than in any of the slates.

There is less pyrite $\left(\mathrm{FeS}_{2}\right)$ in the red and most in the black.

Doctor Hillebrand's discussion of the analyses of New York and Vermont slate and of the causes of the discoloration of the "sea green" is given on pages 39-42. While that investigation was undertaken primarily to determine the cause of discoloration in one kind of slate, microscopic analyses show that discoloration in the black slates of Pennsylvania is also greatest where carbonate is most abundant. It is safe to assume that ferrous carbonate plays an important part in the discoloration, not only in these slates, but in all slates. The red slates of New York State contain much carbonate, but do not discolor, the carbonate probably not being ferrous.

These 29 analyses are sufficient to give within certain limits the essential chemical composition of commercial slate of aqueous sedimentary origin.

\section{Range of composition of slate.}

Silica

Alumina........................

Ferric oxide................

Ferrous oxide Potash

\section{Per cent.} $55-67$

11-23

0. 52-7

$.46-9$
Per cent.

Soda . . . . . . . . . . . . . . . . 0.50-3.97

Magnesia . . . . . . . . . . . . . . . 88-4.57

Lime .................... . . 33-5. 20

Water above $110^{\circ} \mathrm{C} \ldots \ldots \ldots . .2 .82-4.09$ 
For comparison a composite analysis of 51 American Paleozoic shales made by H. N. Stokes of the United States Geological Survey $a$ is added, the unessential elements being also omitted.

Composite analysis of 51 Paleozoic shales.

\begin{tabular}{|c|c|c|}
\hline Per cent. & & er cent. \\
\hline Silica . . . . . . . . . . & Soda.... & 1.01 \\
\hline Alumina ...... & Magnesia & 2.32 \\
\hline Ferric oxide $\ldots \ldots \ldots$ & Lime $\ldots \ldots \ldots \ldots \ldots$ & 1. 41 \\
\hline Ferrous oxide $\ldots \ldots \ldots \ldots \ldots$ & Water above $110^{\circ} \mathrm{C} \ldots \ldots \ldots \ldots . .$. & 3.82 \\
\hline Potash & & \\
\hline
\end{tabular}

As these figures come between the extremes of the slate analyses, and as numerous clays and some schists do also, $b$ it is evident that a chemical analysis of a slate is not sufficiently characteristic to prove that it is not that of a shale, a clay, or a schist. Indeed, but for the low maxima for soda $(2.17,2.59$, and 3.97 per cent) in 3 out of the 29 analyses, and the high minima for combined water, many granites, syenites, porphyries, diorites, and basalts could pass chemically as roofing slate.

That there should be such chemical similarity between slate, shale, and clay results primarily from the fact that the slate here considered is simply metamorphosed shale and that shale is compressed clay. Whatever mineralogical changes metamorphism brought about, the same elemonts persisted. In some mica-slates the grains of quartz, feldspar, zircon, and other minerals are the identical ones of the original clay sediment. The econoinic bearing of the chemical analyses of slates will be brought out under "Methods of testing slate," in the section on economic geology.

\section{CHEMICAL CHANGES IN WEATHERING.}

The changes in substance and color which slates undergo in weathering are striking. The black slate of the Peach Bottom district (Pennsylvania and Maryland) and of Buckingham County, Va., passes into a bright reddish-brown clay, while the black slate of Lehigh and Northampton counties, Pa., passes into a yellowish ocher and finally into a white clay; and the black clay slate of West Virginia passes through similar changes. These alterations will be referred to in describing each district. These changes in weathering should not, however, be confounded with the relatively slight discoloration which slates on the roof undergo during a fraction of a century or even several centuries. The former changes probably required tens of centuries.

Dr. George P. Merrill has investigated the weathering of Peach Bottom slates $c$ and shown that in the passage from the black slate to the red clay the following losses occur: 57.57 per cent of the $\mathrm{SiO}_{2} ; 8.78$ per cent of the iron oxides; all of the lime; 28.16 per cent of the $\mathrm{MgO} ; 77.95$ per cent of the $\mathrm{K}_{2} \mathrm{O}$, and 99.64 per cent of the $\mathrm{Na}_{2} \mathrm{O}$; while all of the $\mathrm{Al}_{2} \mathrm{O}_{3}$ remains, as well as the water. A piece of Peach Bottom slate in the first stages of weathering, examined microscopically by the writer, shows the magnetite crystals and lenses passing into hematite and the andalusite crystals becoming limonitic from the oxidation of its ferruginous inclusions.

In connection with some chemical analyses of slates from Lehigh County, Pa., Doctor Hillebrand made some partial analyses of a piece of black slate from a ledge near the Berks and Lehigh County line, $1 \frac{1}{4}$ mile north-north west of Rothrocksville, on the road from that place to Hynemansville, in which the stages of weathering were finely shown. Analysis A is of the black but slightly altered part of the slate; B is of the greatly altered white part of the same specimen. The alteration has proceeded first along the bedding planes, which there undulate in a vertical direction and from

a Bull. U. S. Geol. Survey No. 168, p. 17 (B), 1900.

$b$ For clays see H. Ries, Technology of the clay industry, Sixteenth Ann. Rept. U. S. Geol. Survey pt. 4. pp. 523-575, 1895, pp. 554-575; also Prof. Paper No. 11, 1903. For schist, see Bull. 148, Analyses of Rocks, etc., Clarke and Hillebrand, p. 221 (L) and p. 99 (K), 1897.

c Ireatise on rocks, rock weathering, and soils, N. Y., 1897. 
these along the cleavage, which dips only about $12^{\circ}$. These analyses, when compared with analysis A of fresh black slate from the Slatington quarries (see p. 84), 14 miles farther north-northeast, show a probable loss of 4 per cent of $\mathrm{CaO}$ during a still earlier stage of weathering.

Analyses of weathered slates from Pennsylvania.

\begin{tabular}{|c|c|c|}
\hline & A. & B. \\
\hline \multirow{2}{*}{ 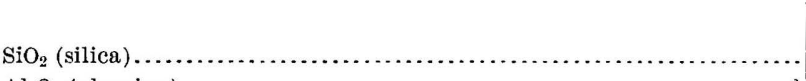 } & Per cent. & Per cent. \\
\hline \multirow{3}{*}{\multicolumn{3}{|c|}{$\begin{array}{l}\mathrm{Al}_{2} \mathrm{O}_{3} \text { (alumina) } \ldots \ldots \ldots \\
\mathrm{P}_{2} \mathrm{O}_{5}(\text { phosphoric oxide) } \ldots \ldots \ldots \ldots \ldots \ldots\end{array}$}} \\
\hline & & \\
\hline & & 16.44 \\
\hline \multirow{2}{*}{\multicolumn{3}{|c|}{$\mathrm{Fe}_{2} \mathrm{O}_{3}$ (ferric oxide) }} \\
\hline & 4.19 & 3.14 \\
\hline \multicolumn{3}{|l|}{ 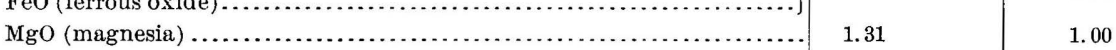 } \\
\hline 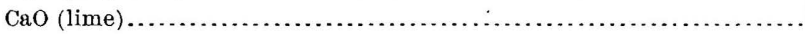 & .20 & .20 \\
\hline 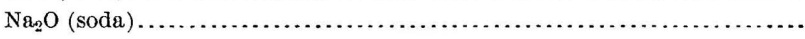 & .26 & .27 \\
\hline 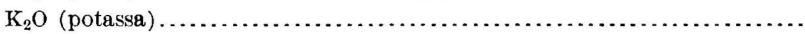 & 3.81 & 4. 32 \\
\hline 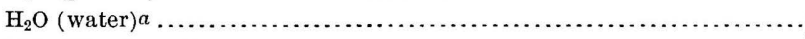 & 7.09 & 5.33 \\
\hline \multirow{4}{*}{ 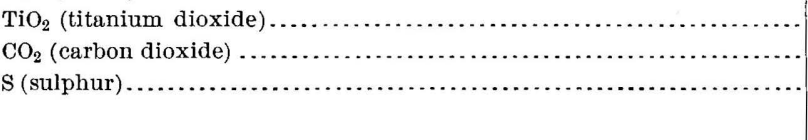 } & & .77 \\
\hline & None. & None. \\
\hline & $.62=.04 \mathrm{FeS}_{2}$ & ……... \\
\hline & 100.18 & 100.28 \\
\hline
\end{tabular}

$a$ Including carbonaceous matter.

A thin section of another specimen from the same ledge, made across both dark and light parts, shows under the microscope:

1. Absence of carbonate in both, this having been previously dissolved out.

2. Many spherules of pyrite in the dark part, some of which, altered to limonite, still remain in the white part.

3. Quartz grains, equally numerous in both.

4. Muscovite (sericite) much more conspicuous in the light than in the dark part.

To the above data should be added two analyses of white "shale clays," by Doctor Hillebrand, which are regarded as the residual product of the weathering of the black slate.

Analyses of shale clays from Lehigh County, Pa.

\begin{tabular}{|c|c|c|}
\hline & C. & D. \\
\hline & Per cent. & Per cent. \\
\hline $\mathrm{SiO}_{2}$ (silica) $\ldots \ldots \ldots \ldots \ldots \ldots \ldots$ & 64.50 & 75.77 \\
\hline 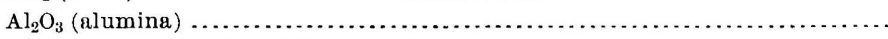 & $a 21.67$ & $b 15.30$ \\
\hline 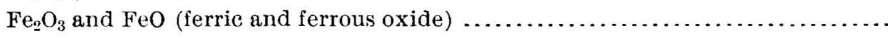 & 1.83 & ........ \\
\hline MgO (magnesia) $\ldots \ldots \ldots \ldots \ldots \ldots \ldots \ldots \ldots \ldots \ldots \ldots \ldots$ & 1.09 & .81 \\
\hline 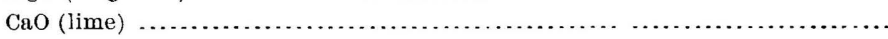 & .18 & .20 \\
\hline $\mathrm{Na}_{2} \mathrm{O}($ soda $) \ldots \ldots \ldots \ldots \ldots \ldots \ldots \ldots . . . . . . . .$. & .20 & Trace. \\
\hline 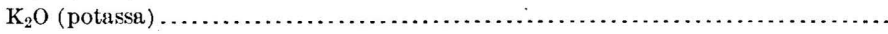 & 4.26 & 2.85 \\
\hline 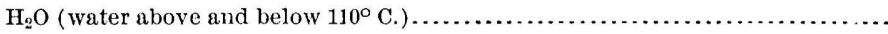 & $c 5.65$ & 4. 69 \\
\hline \multirow[t]{2}{*}{ 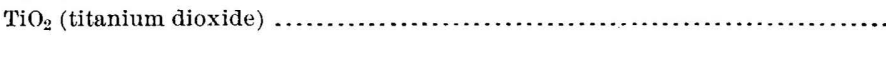 } & .85 & .36 \\
\hline & 100.23 & 99.98 \\
\hline
\end{tabular}

$a$ Including $\mathrm{P}_{22} \mathrm{O}_{5} . \quad b$ With trace of $\mathrm{Fe}_{2} \mathrm{O}_{3}$ and (perhaps) $\mathrm{P}_{2} \mathrm{O}_{5} . \quad c$ Ignition loss.

C. White "shale clay" quarried for fire clay a hali mile south of Fogelsville, Upper Macungie, Lehigh County, Pa.

D. White "shale clay" associated with limonite one-fourth mile northwest of Guth Station, South Whitehall, Lehigh County, Pa. 
The significance of these analyses and microscopic examinations is that this slate in weathering first loses its carbonate, then its carbonaceous matter, then its pyrite, and has its feldspathic material, if any, changed to kaolin, while its muscovite remains partly unaltered and its quartz largely so. The bleaching process in the slates of Lehigh and Northampton counties, Pa., apparently proceeds by these steps:

1. Removal of carbonates of lime and magnesia, accompanied by oxidation of the ferrous carbonate and deposition of limonite.

2. Oxidation and removal of carbon; also oxidation and removal of pyrite.

3. Removal of almost all limonite.

In general, therefore, while slate in weathering returns to a clay, this clay, in some cases, differs from that in which the slate must have originated by the absence of carbon and the small amounts of silica, potash, and soda, and in others by the absence or extremely low percentages of carbon, lime, and iron.

\section{NOTES ON THE CHEMICAL COMPOSITION OF THE ROOFING SLATES OF EASTERN NEW YORK AND WESTERN VERMON'. a}

\section{By W. F. Hillebrand.}

Before the analyses of any of the slates were undertaken, it was well understood that the chief question of economic importance to be solved was the cause of fading observed in some, but not all, of the green slates after longer or shorter exposure to atmospheric influences. Attention was therefore primarily directed toward its elucidation, and the evidence accumulated will be herein set forth. Naturally, in the course of the work, opportunity was afforded for drawing conclusions as to the combination of certain chemical elements concerning which the microscope could furnish no satisfaction. A few remarks in this connection may therefore well be in place.

It soon became clear that there was no apparent connection between the percentage of iron sulphide $\left(\mathrm{FeS}_{2}\right)$ in any green slate and its liability to fade; that, furthermore, the visible sulphide was of an extremely resistant type, and often after years of exposure retained its original luster undimmed; that it was probably true pyrite. The possibility remained that there might be finely divided $\mathrm{FeS}_{2}$ in the much more readily decomposable form of marcasite. Microscopical evidence made it clear that if present at all it was in amount altogether too trifling to produce the fading effect often observed.

It was found that the ferrous iron, other than that in the pyrite, was almost entirely in a very soluble condition. Even when carbonates were absent, a large proportion of it dissolved in moderately dilute acids after very few minutes boiling. But the ferrous iron thus shown to exist in the silicate minerals could not be accepted as the cause of fading, because it exists in all slates; and some of the most ferruginous, as $314 f$, are "unfading." Microscopical evidence is also opposed to oxidation of ferrous silicates as the cause of fading.

There remained as its sole probable cause the carbonate found in nearly all of the slates. Its chemical behavior toward acids proves beyond question that this carbonate can be in no observed case calcite. Were it even in small part so, an instantaneous disengagement of gas would be apparent on adding acids, whereas their action is tardy and becomes pronounced only on application of heat. To those familiar with the behavior of different carbonates this evidence alone is decisive.

The carbonate is, therefore, an isomorphous mixture, and indeed the $\mathrm{CO}_{2}$ found, as compared with the $\mathrm{CaO}$, shows at once a great excess of the former. That $\mathrm{CaCO}_{3}$ is one of the chief isomorphous constituents appears from the fact that absence of $\mathrm{CO}_{2}$ uniformly accompanies the lowest trifling percentages of $\mathrm{CaO}$, and that increase of $\mathrm{CaO}$ carries with it an approximately corresponding one of $\mathrm{CO}_{2}$. The $\mathrm{CO}_{2}$ is usually in molecular excess of the $\mathrm{CaO}$, and sometimes of the $\mathrm{MnO}$ and $\mathrm{FeO}$ as well (compare

$a$ Reprinted from Nineteenth Ann. Rept., part 3. The analyses and microscopic descriptions he: $\mathrm{t}$ referred to will be found under New York and Vermont slates. 
analyses $\mathrm{L}, \mathrm{M}, \mathrm{Q}, \mathrm{R}$ ); $a$ hence $\mathrm{MgCO}_{3}$ is indicated as the next most important isomorphous element of the carbonate. Analyses $\mathrm{M}, \mathrm{Q}$, and $\mathrm{R}$, taken together in the order named, afford positive evidence that $\mathrm{MnCO}_{3}$ is present either as an independent mineral or as a component of the complex carbonate, for as $\mathrm{CO}_{2}$ decreases from the green center through the purple rim to the outer red, so does $\mathrm{MnO}$, and at such a rate that with no carbon dioxide $\mathrm{MnO}$ would likewise disappear. In general, too, those slates high in $\mathrm{CO}_{2}$ show a relatively high $\mathrm{MnO}$ content. Analysis 201d (p. 71) shows also that manganese carbonate is found as a vein formation in the slates, and Professor Dale has found with the microscope some indications of its presence in the lenses of the red slate, at least. In order to be able to credit the fading to the carbonate, it is necessary still to show that it contains $\mathrm{FeCO}_{3}$ as a constituent, for, while the manganese might produce discolorization by oxidizing, its amount is slight, and the color due to its oxidation products alone would be black rather than brown. Because of the above-mentioned ready solubility of the ferrous silicate or silicates in acids, chemical proof of the presence of ferrous carbonate is not obtainable, but from our general knowledge of its relations to those of magnesium and manganese it is in the highest degree probable that it does exist either as a distinct mineral or as a component of the dolomitic carbonate, and, in fact, it would be somewhat surprising if, with magnesium and manganese present as carbonates, iron should be absent. The needed proof, however, is supplied by the microscope, as detailed in the text of Professor Dale's report (p. 105).

If it is objected that some green slates comparatively rich in carbonate fade less than others which are much poorer, it may be reasonably urged that the relative proportions of the several carbonates are doubtless subject to change in different slates, as in the natural order of things they must be, since the original composition of the slate-forming materials must have differed in each case. This being so, it follows that a mere testas to the relative amount of $\mathrm{CO}_{2}$ can furnish no guide in advance as to the fading qualities of a slate, as might be the case were the composition of the mixed carbonates always constant.

While pyrite is never a visible constituent of the red slates, there seems no other way to account for the sulphur found, since careful tests failed by far to show an equivalent amount of $\mathrm{SO}_{3}$. Hence in the analysis pyrite is reported in all cases.

The phenomenal percentage of barium in $201 e(\mathrm{~K})$, as compared with other slates, has been of service as showing that, in this case at least, it is mainly, if not altogether, a constituent of some silicate, or silicates, and not of barite only, which latter mineral, according to Professor Dale, has been observed on joint planes and in crystalline concretions, for the sulphur is totally inadequate to form barite in this case.

The condition of the nickel and cobalt has not been definitely ascertained. From the analysis of the manganese carbonate $201 d$ it might appear as if they were constituents of the carbonate in the slates, but it is not impossible that they may be in combination with arsenic, or arsenic and sulphur, as arsenides and sulpharsenides, even if the presence of arsenic has not been revealed, no test having been made for that element. In all the tests made for nickel and cobalt, both elements were found, and in one case, probably a maximum, their combined percentage as oxides was 0.025 .

Heating of the slates in tubes closed at one end gave without exception alkaline vapors and whitish sublimates, which latter reacted for $\mathrm{SO}_{3}, \mathrm{Cl}$, and strongly for $\mathrm{NH}_{3}$. In eight cases the amount of ammonia thus given off in both conditions was ascertained by nesslerization and found to range from 0.0075 per cent in the case of $760 a$ $(\mathrm{H})$ to 0.04 per cent for $305 d(\mathrm{P})$. This last is a black slate carrying nearly 0.5 per cent of carbon, but the ammonia obtained was not sensibly higher than in some of the green slates, as $645 a(\mathrm{~F})$ with 0.035 per cent $\mathrm{NH}_{3}$, or 314 of ' 95 (I), with 0.03 per cent $\mathrm{NH}_{3}$. 
Neither the condition nor the source of the nitrogen thus revealed can be stated with any degree of positiveness. It is found in the interior of fresh and unbroken masses, and hence is not to be regarded as derived from infiltration of nitrogenous matter since the opening of the quarries. Whatever may be its manner of combination, nitrogen is coming to be recognized as a primary constituent of many rocks and minerals. It seems probable that in the present instance its presence is to be attributed to that of the organic matter which was doubtless not wanting when the materials now composing the slates were originally laid down.

Chromium and vanadium are probably minor constituents of all the slates. They were not looked for in making the foregoing analyses, but in connection with some more recent work relating to the distribution of vanadium in the rocks of the earth's crust, $a$ the sea-green slate $230 a(\mathrm{~A})$ and the red slates $201 e(\mathrm{~K})$ and $397 e(\mathrm{~L})$ were examined. In $201 e$ there was found 0.017 per cent of vanadium as $\mathrm{V}_{2} \mathrm{O}_{5}$ and 0.007 per cent of chromium as $\mathrm{Cr}_{2} \mathrm{O}_{3}$. In a mixture of equal parts of the two red slates there was found of $\mathrm{V}_{2} \mathrm{O}_{5} 0.008$ per cent and $\mathrm{Cr}_{2} \mathrm{O}_{3}$ about as in the first case.

To the novice a cursory examination of the tabulated analyses might seem to indicate a greater diversity in essential composition than comports with the facts. Thus, there seems to be, perhaps, little relation in composition, except qualitatively, between the red slates $358 d(\mathrm{~J})$ and $397 e(\mathrm{~L})$. Yet, after deduction of all $\mathrm{CaO}$ as phosphate and carbonate, of all $\mathrm{MnO}$ as carbonate, and of enough $\mathrm{MgO}$ as carbonate to satisfy the remainder of the $\mathrm{CO}_{2}$, also of the trace of pyrite, amounting to 16.58 per cent in all, and calculating the remaining 83.80 per cent to 100 , there result the figures given in the first column below, for comparison with which analyses $358 d(\mathrm{~J})$ and $201 e(\mathrm{~K})$ of slates naturally altogether or nearly free from carbonates are partially reproduced:

\begin{tabular}{|c|c|c|c|c|c|c|c|}
\hline & $397 e(\mathrm{~L})$ & $358 d(\mathrm{~J})$. & $201 e(\mathrm{~K})$ & & $397 e(\mathrm{~L})$. & $358 d(\mathrm{~J})$ & $201 e(\mathrm{~K})$ \\
\hline $\mathrm{SiO}_{2} \ldots \ldots \ldots \ldots$ & 67.40 & 67.61 & 67.55 & $\mathrm{~K}_{2} \mathrm{O}$ & 4.50 & 4.45 & 4.13 \\
\hline $\mathrm{TiO}_{2} \ldots \ldots \ldots \ldots$ & .57 & .56 & .58 & $\mathrm{Na}_{2} \mathrm{O} \quad \ldots \ldots \ldots \ldots \ldots$ & .62 & .67 & .61 \\
\hline $\mathrm{Al}_{2} \mathrm{O}_{3} \ldots \ldots \ldots \ldots \ldots$ & 13.84 & 13.20 & 12.59 & $\mathrm{H}_{2} \mathrm{O}$ below $110^{\circ} \mathrm{C}$. & .44 & .45 & .40 \\
\hline $\mathrm{Fe}_{2} \mathrm{O}_{3} \ldots \ldots \ldots \ldots$ & 4.15 & 5. 36 & 5.61 & $\mathrm{H}_{2} \mathrm{O}$ above $110^{\circ} \mathrm{C}$. & 3.37 & 2.97 & 3.03 \\
\hline $\mathrm{FeO} \ldots \ldots . . . . . .$. & 1. 70 & 1. 20 & 1.24 & \multirow{3}{*}{ 'Total. } & \multirow{3}{*}{100.00} & \multirow{3}{*}{99.71} & \multirow{3}{*}{99.32} \\
\hline $\mathrm{BaO} \ldots \ldots \ldots \ldots \ldots$ & .07 & .04 & .31 & & & & \\
\hline $\mathrm{MgO} \ldots . . . \ldots \ldots . . .$. & 3.34 & 3.20 & 3.27 & & & & \\
\hline
\end{tabular}

When it is borne in mind that a portion of the FeO in 397e should doubtless be credited to the carbonate, whereby an equivalent of $\mathrm{MgO}$ would be released for the silicate, it will be seen that the agreement as to $\mathrm{FeO}$ in the above comparison would be much closer, and the three slates may be said to have almost identically the same composition when compared in this manner.

Applying a similar correction to the three analyses of $397 a \mathrm{R}, \mathrm{Q}$, and $\mathrm{M}$, in the order named, we obtain the following corrected figures for the green spot, the purple rim, and the outer red, which bring into special prominence their relatively high silica contents as compared with all the other slates analyzed:

\begin{tabular}{|c|c|c|c|c|c|c|c|}
\hline & $397 a(\mathrm{R})$ & $397 a(\mathrm{Q})$. & $397 a(\mathrm{M})$ & & $397 a(\mathrm{R})$. & $397 a(\mathrm{Q})$ & $397 a(\mathrm{M})$. \\
\hline $\mathrm{SiO}_{2} \ldots \ldots \ldots \ldots$ & 76.04 & 73.64 & 71.59 & $\mathrm{~K}_{2} \mathrm{O} \quad \ldots \ldots \ldots \ldots \ldots$ & 4.15 & 4.22 & 3.87 \\
\hline $\mathrm{TiO}_{2} \ldots \ldots \ldots \ldots$ & .60 & .58 & .53 & $\mathrm{Na}_{2} \mathrm{O} \quad \ldots \ldots \ldots \ldots \ldots$ & .26 & .26 & .22 \\
\hline $\mathrm{Al}_{2} \mathrm{O}_{3} \ldots \ldots \ldots \ldots \ldots$ & 10.90 & 11.66 & 10.95 & $\mathrm{H}_{2} \mathrm{O}$ below $110^{\circ} \mathrm{C} .$. & .29 & .32 & .30 \\
\hline $\mathrm{Fe}_{2} \mathrm{O}_{3} \ldots \ldots \ldots \ldots \ldots$ & 1.27 & 2.04 & 4.33 & $\mathrm{H}_{2} \mathrm{O}$ above $110^{\circ} \mathrm{C} .$. & 2.45 & 2.61 & 2.78 \\
\hline $\mathrm{FeO} \ldots \ldots \ldots \ldots$ & 1.23 & 1.36 & 1.61 & \multirow{3}{*}{ Total .. } & \multirow{3}{*}{100.00} & \multirow{3}{*}{99.99} & \multirow[t]{3}{*}{100.00} \\
\hline $\mathrm{BaO} . . . . . . . . .$. & .06 & .05 & .05 & & & & \\
\hline $\mathrm{MgO} \ldots \ldots \ldots \ldots$ & 2.75 & 3.25 & 3.77 & & & & \\
\hline
\end{tabular}

$a$ Distribution and quantitative occurrence of vanadium and molybdenum of rocks in the United States, by W. F. Hillebrand: Am. Jour. Sci., 4th ser., vol. 6, 1898, p. 209. 
The foregoing calculations for $397 e$ and $397 a(\mathrm{~L}$ and $\mathrm{M})$ show at the same time the general dolomitic character of the carbonate, as appears from the following table, wherein the percentages of carbonates are given as calculated on the above-predicated assumptions:

\begin{tabular}{|c|c|c|c|c|c|c|c|c|}
\hline & $397 e(\mathrm{~L})$ & $\begin{array}{l}\text { Molecu- } \\
\text { lar ratio. }\end{array}$ & $397 a(\mathrm{R})$ & $\begin{array}{l}\text { Molecu- } \\
\text { lar ratio. }\end{array}$ & $397 a(\mathrm{Q})$. & $\begin{array}{l}\text { Molecu- } \\
\text { lar ratio. }\end{array}$ & $397 a(\mathrm{M})$. & $\begin{array}{l}\text { Molecu- } \\
\text { lar ratio. }\end{array}$ \\
\hline $\mathrm{CaCO}_{3} \ldots \ldots \ldots$ & 8.95 & 1.03 & 7.93 & 1.15 & 7.11 & 1.16 & 6.14 & 1.15 \\
\hline $\mathrm{MgCO} \ldots . . . .$. & 6.93 & 10 & 5.36 & 700 & 4. 77 & 10 & 4.22 & 10 \\
\hline $\mathrm{MnCO}_{3} \ldots \ldots \ldots$ & .48 & 1.00 & .57 & 1.00 & .47 & 1.00 & .38 & 1.00 \\
\hline Total........... & 16.38 & .......... & 13.86 & ........... & 12.35 & $\cdots$ & $\cdot 10.74$ & \\
\hline
\end{tabular}

If, as is quite probable, a small fraction of the $\mathrm{CaO}$ should be charged to the silicates, the true dolomitic ratio would be more closely approached. It is of no consequence for the above calculations that an undeterminable portion of $\mathrm{FeCO}_{3}$ should appear as $\mathrm{MgCO}_{3}$. The ratios are not thereby affected.

\section{ECONOMIC GEOLOGY OF SLATE.}

\section{DIFFICULTIES IN SLATE QUARRYING.}

The difficulties in slate quarrying are many. Assuming that the commercial value and the grade of fissility of the slate itself have been fully determined by scientific and practical tests, the opening of a quarry offers serious problems. These concern the thickness of the deposit and of the weathered "top," the character of the jointing, the presence of faults, shear-zones, and dikes. There are also the practical matters of drainage, of the location of dumps, of transportation facilities, and of fuel. The cost of slate at some quarries is increased by the necessity of removing the dumps of former workings, which, for lack of capital or of good judgment, were placed on good slate. Sometimes the only way to remove these old dumps is to throw them into the quarry on one side and hoist them up at the other. In places where the beds are steeply inclined or vertical as the quarry deepens one of the walls falls in and the removal of this material entails great expense. The occasional employment of a consulting engineer would obviate mechanical accidents of this nature by the mathematical determination of the points at which supporting walls should be left. There are also uncertainties of a stratigraphic character which the use of the core drill would eliminate from many a slate-quarrying venture.

The percentage of waste is generally high in slate quarrying. Watrin (see Bibliography, p. 145), referring to the Ardennes region, gives the total waste at from 70 to 75 per cent in weight, of which 20 to 25 occur in the quarry and 50 in splitting. Merrill estimates the waste in the Peach Bottom region as 88 per cent. In the Maine quarries it is also large, owing to the frequent interbedding of the slate with quartzite.

\section{BEDDING AND CLEAVAGE-HOW DISTINGUISHED.}

Wherever the slates are traversed by "ribbons," or marked changes in color occur and persist through a thickness of several feet, or wherever strips of quartzite or limestone occur at intervals and continue longitudinally for several hundred feet, quarrymen of any experience know that they have to do with beds, and that the quality of the slate of any one bed may be expected to continue along that bed, unless some change should occur in the character of the cleavage. The quality of the slate is primarily dependent upon the character of the sediment. This changes less frequently in a horizontal than in a vertical direction. The changes in the character of the materials brought into the sea and deposited at one time throughout a 
moderately large area were fewer than between those brought in at different times at any one spot. Cleavage being the result of a later compression may traverse sediments of slightly different composition with ltttle change in direction, but will be very much affected by great changes in the material or the grain of the sediment (see Pl. II, $B$ ). The prime factor is, then, the bed, the second one the cleavage.

In the southern part of the slate belt of western Vermont, where beds of quartzite or limestone are few and inconspicuous and the difference of color is slight, the distinction between bedding and cleavage is not easily made. Quarrymen and prospectors sometimes regard them as identical when they differ. Where the strikes of the bedding and cleavage are divergent, if that of the cleavage be mistaken for that of the bedding, a new opening may easily be made at the wrong point and the looked-for bed may be missed (see fig. 3). In such places the readiest means of distinguishing cleavage and bedding are:

(1) The fossil impressions (trails or algæ, sometimes called "wavers") are always on a bed surface.

(2) Minute plicated beds of calcite and quartz indicate bedding.

(3) A microscopic section transverse to the cleavage, if other means fail, may indicate the amount of divergence between the bedding and the cleavage (see fig. C, Pl. VI).

In some places, however, bedding and cleavage are identical in both strike and dip.

\section{"FLINTS"-THEIR NATURE AND CAUSE.}

Beds of quartzite, often calcareous, micaceous, pyritiferous (see Pl. V, $A$ ), should never be confounded with veins of quartz (see $\mathrm{Pl}$. $\mathrm{V}, B$ ). In some regions they are both indiscriminately designated by the quarrymen as "flints." The former are sediments mainly of quartz sand, and, although varying consid-

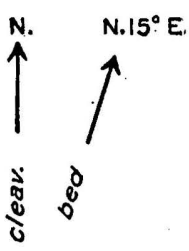

quarry

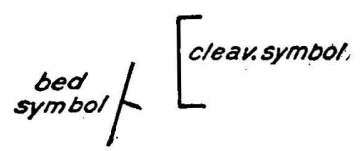

FIG. 3.-Diagram illustrating the effect of divergence in strike of slate bedding and cleavage. erably in thickness, are generally more persistent than the veins which, as has been already shown, are chemical infiltrations into fractures produced at a much later time in consequence of various stresses. Ordinarily the quartzite has a more granular and less glassy surface than the vein quartz. A microscopic section under polarized light will almost always show the difference when ordinary means fail. The importance of not confounding the quartzite beds and the quartz veins lies in this-that while the quartzite beds indicate the direction and thickness of adjacent beds of slate, and thus prove helpful, the quartz veins constitute perhaps the most fortuitous and the most pernicious element in slate quarrying. The strains which the slate masses have suffered have been so various that it is almost impossible to foretell the probable presence, course, extent, or thickness of a quartz vein. A few things should, however, be noted. While the fractures which occasioned the veins are to be looked upon somewhat as accidental, they are the result of stresses affecting large areas or of the complex interactions of pressure in a few definite directions. The course of a vein which is tapering out should be taken with a compass, and another should be somewhat expected in the same line or in directions parallel to it, or at nearly a right angle to it.

Bull. 275-06-4 


\section{RELATIONS OF JOINTS, DIKES, AND SHEAR ZUNES.}

From the similarity of the courses of the diagonal joints and of many of the dikes and "hogbacks" in western Vermont and eastern New York there seems to be a close relationship between them.

They may all have been produced by the same stress at the same time, in some cases the strain resulting in a hogback, in others in a diagonal joint; and these joints, when very deep, may have given rise to dikes. The practical application of this is that the possibility of such a relationship should lead the quarryman, whenever he finds diagonal jointing, to suspect the proximity of hogbacks and dikes with a similar course, and so with either a hogback or a diagonal dike, and this suspicion may sometimes save expenditure of time and labor.

\section{USE OF A GEOLOGICAL MAP AND COMPASS IN PROSPECTING FOR SLATE.}

Although the following paragraphs refer particularly to the western Vermont and eastern New York slate belt-and necessarily so because this is the only slate region which has been mapped in this way - the general principles and method of procedure are applicable to any slate region where the beds consist of close and more or less overturned folds.

The quarry maps, Pls. XX and XXI, are designed to be of practical utility. The coloring shows where the Cambrian green and purple and the Ordovician red slates may be looked for or not looked for. The dovetailing of the Cambrian and Ordovician areas represents to a certain extent structnral relations and not mere "accidents" of erosion. Thus, the Jamesville Cambrian belt is closely related to the Cambrian belt which lies east of South Granville.

On the quarry maps the course of bedding and cleavage has been shown at several quarries by special symbols. The scale of these maps is sufficiently large to admit the entry of many more quarries and symbols. By using a small geological compass to determine the strike of any bed of good slate at any of the located quarries, and transferring it to the quarry map by means of a protractor, the probable direction of the recurrence of the bed can be ascertained, and so with joints, hogbacks, or dikes. Such a compass should be provided with sights, spirit levels, movable ring to set off magnetic variation, and have a clinometer attachment to indicate angle of dip.

Where, as at West Pawlet (see section VII, Pl. XXII, and figs. $A, B, C, \mathrm{Pl}$. XXIII), the slate is closely folded, a succession of repetitions of the same series of beds may be looked for in an east-and-west direction at varying intervals. The possibility of the pitching of the axis of a fold in a northerly or southerly direction should be looked out for. In such cases older or newer beds are traversed in following the direction of the pitch. Where an Ordovician belt abruptly cuts off a Cambrian one on the north or south, the Cambrian one must ordinarily be supposed to plunge under the Ordovician one.

From the relations already explained, quarrymen need not be surprised, here and there, as the excavation proceeds, to come upon the Ordovician red and bright green slates at the bottom of a sea-green or unfading green quarry, or to come upon these Cambrian slates at the bottom of a red slate quarry (sections I, II, V, VI, VII, Pl. XXII).

Quarrymen are very skilled in detecting the presence of good slate from the peculiar appearance of the weathered edge surface, and that skill appears to have been their only guide in prospecting in this region. It would be well if this skill were reenforced by the use of the following method in exploration:

First. Make reference to a geological map for the areas in which the various slates may occur.

Second. Determine on quarry map or general map the good slate beds already exploited. 
Third. Make compass determination of the strike of such beds.

Fourth. Explore along that strike.

Fifth. Explore at right angles to that strike to see if the series is repeated by folding. (Note order of horizons in table facing p. 94.)

Sixth. Trench at promising localities across the strike to expose as large a series as possible.

Seventh. When surface indications are favorable, make an opening large enough to determine angle of dip of both bed and cleavage and to obtain specimens sufficient for tests given on pages 45-49.

Eighth. Bore with diamond or steel-shot drill at $45^{\circ}$ to cleavage dip, so that the core will split up into elliptical pieces sufficiently larger than diameter of core to be conveniently tested.

Ninth. Measure thickness at right angles to bedding planes on the core.

The map of the Slatington, Pa., slate district (Pl. XVI), upon which the quarries are carefully located and the strike and pitch shown, is also designed for practical use.

\section{METHODS OF TESTING SLATE.}

Methods of testing the elasticity, absorption, fissility, and resistance of roofing slates have been in use for many years, and many more or less complete chemical analyses of slate have been published. In recent years, however, more exact methods of reaching these results have been devised. All such methods have here been brought together. If parts of one specimen, fairly representıng the average quality of the product of any quarry or prospect, or if parts of each of a series of specimens, fairly representing all the different varieties and qualities there obtained, were to be subjected respectively to the tests described, such a slate or slates may be said to have been for all economic purposes exhaustively investigated. Several of these tests are of so simple a character as to be very easily applied. This list of methods is largely compiled from Böttinger, Fresenius, Hutchins, Jannetaz, Merriman, Reverdin and de la Harpe, Sorby, Umlauft, and J. F. Williams. $a$ Although they all offer valuable suggestions, the most useful papers on the subject are those of Fresenius, Umlauft, and Merriman.

Sonorousness.-One of the first and most time-honored tests of roofing slate is to suspend a good-sized piece of the usual thinness and tap it with some hard object. If it possesses the molecular structure of a slate it will yield a semivitreous ring. A clay slate will be less sonorous than a mica slate, but mica slates with a large percentage of chlorite and possibly a little talc will be deficient in sonorousness. It is because of this property that when at the quarries refuse slates are thrown upon the dumps the sound produced is not unlike that made by the smashing of a large quantity of crockery.

Cleavability. - This test should be applied by an experienced workman. The block should be freshly quarried, unfrozen, and moist. The chisel should be very thin and about 2 inches wide. The cost of slate is closely related to the degree of its cleavability.

Cross fracture ("sculping").-This is to determine the character of the "grain." This test should also be applied by an experienced hand to a large block several inches thick, with a stout chisel and a long-handled heavy mallet. Jannetaz ${ }^{b}$ published a method for determining with scientific precision the direction of the grain in slate when it is but obscurely shown on the cleavage surface. The slate is sawn in a direction parallel to its cleavage and one of the sawn surfaces is made exceedingly smooth and covered with an even and very thin coat of grease. The point of a red-hot platinum wire is applied to the slate opposite the center of the greased

$a$ Full titles are given in the economic Bibliography, pp. 138-145.

$b$ Relations entre la propagation de la chaleur et l'élasticité sonore dans les roches, 1877, p. 417. 
surface. The greased area reached by the heat will, in cooling, leave an oval outline, the long axis of which will show the direction of the grain, the heat having traveled more rapidly within the slate in the direction of the grain than in any other. $\mathrm{He}$ also made a disk of slate 5 inches in diameter of ordinary thickness, with a central perforation. This disk was fastened by the extremities of the diameter parallel to the grain and afterwards by that at right angles to the grain, and was made to vibrate by tapping the side of the perforation. The sound produced when the disk was fastened by the diameter at right angles to the grain was louder than when fastened by that parallel to it. In other words, the direction of the grain was that in which elasticity and vibration were greatest.

Character of clecirage surface.-The cleavage surface should be examined with an ordinary magnifying glass. A superior slate should scale along the cleavage surface into very thin chips with translucent edges. If the grain is pronounced it will appear in fine transverse lines. If false cleavage, which is fatal, be present, it can usually be detected on the cleavage surface. Ribbons, which are sometimes lines of weakness, should be noted. There is great difference in the smoothness of the surface in slates of different regions. Ordinarily the constituent minerals ought not to be visible. Minute lenses or crystals are not necessarily detrimental, but they retain dust and thus afford a foothold for mosses and other cryptogams, which gather moisture and thus aid the decomposition of the slate.

Presence of lime.-This can be determined by the application of cold dilute hydrochloric acid to the edges of a freshly-quarried slate. Rapid effervescence implies presence of carbonate of lime; slow, that of a lesser quantity of it or of dolomitecarbonate of lime and magnesia. Reverdin and de la Harpe call attention to the fact that good slate may have a high percentage of calcium carbonate, while others free from it may be poor. ${ }^{a}$ But it is nevertheless true that slates containing such a percentage of lime must, other things being equal, in time be acted upon more powerfully by the acids of the atmosphere than those without any or with an infinitesimal one.

Color and discoloration.-The color of the freshly-quarried slate should be noted and compared with that of pieces exposed for several years to the weather, either on a roof or on the quarry dumps, or with that at the top of the quarry close to the gravel, although this last comparison may not always be perfectly conclusive. The value of slates is somewhat affected by the extent of their discoloration.

Presence of clay.-This should be tested by breathing upon a fresh and clean piece of slate and observing whether there is any argillaceous odor. The very best slate will not emit any such odor.

Presence of marcasite.-A slate containing lenses or crystals of a pale-yellowish metallic mineral which, on exposure, decomposes, forming a yellowish white film and rusty spots, is poor $;^{b}$ but pyrite in small quantity is not necessarily detrimental, for it does not decompose readily. It is present in nearly all slates, and particularly in black slate.

Presence of magnetite.-Since slate has come to be used so largely in electric appliances the determination of the relative abundance of this mineral is of practical importance. A cubic inch of the slate should be weighed, broken up, and reduced to a fine powder in an agate mortar or else between sheets of zinc or copper, and then spread on a flat surface and thoroughly traversed by a strong magnet and the extracted magnetite weighed. The percentage, by weight, per cubic inch of slate can thus be determined.

\footnotetext{
a See Bibliography, p. 145.

$b$ See Alexis A. Julien, On the variation of decomposition in the iron pyrites; its cause, and its relation to density: Annals N. Y. Acad. Sci., vol. 3, pp. 365-403; vol. 4, pp. 125-221 and Pls. VIII, IX; 1886,1887 . Also, A. P. Brown, On marcasite and pyrite; a comparative study of the chemical behavior of pyrite and marcasite: Proc. Am. Phil. Soc., vol. 33, pp. 225-243, 1894. Also, H. N. Stokes, On pyrite and marcasite: Bull. U. S. Geol. Survey No. 186, 1901.
} 
Strength.-Merriman's apparatus for testing the strength of slate is described in his paper: $a$

The pieces were supported in a horizontal position upon wooden knife-edges 22 inches apart, and these loads were placed upon another knife-edge halfway between the supports. This load was applied by means of sand running out of an orifice in a box at the uniform rate of 70 pounds per minute, and by the help of an electric attachment the flow was stopped at the instant of rupture.

He computes the modulus of rupture by the use of this formula, $\mathrm{S}=\frac{3 \mathrm{wl}}{2 b d^{2}}$, in which $\mathrm{w}$ is the load in pounds which causes the rupture, 1 the distance between the supports in inches, $b$ the breadth and $d$ the thickness of the plate in inches. $\mathrm{S}$ is the number of pounds per square inch. According to these tests the modulus of rupture in the best slates should range from 7,000 to 10,000 pounds.

J. F. Williams $b$ made tests of compression and elastic limit on purple, red, and green slates from Rutland and Washington counties. His results give a modulus of rupture ranging from 7,310 to 10,800 pounds per square inch. Campbell \& Donald $c$ give 20,000 pounds as the crushing weight for 1 cubic inch of slate. Wilkinson, in his Practical Geology of Ireland, gives 30,730 pounds as the crushing weight of the Killaloe slates. $d$ Watrin $e$ gives the maximum crushing weight of some French slates as 2,000 kilograms per square centimeter, but 1,700 as the average.

Merriman has also devised an impact test for determining the strength of slates. He lets a wooden ball weighing 15.7 ounces fall 9 inches upon a piece of slate measuring 6 by $7 \frac{3}{4}$ inches by from 0.20 to 0.28 inches thick, and repeats the blows until the slate breaks. The foot pounds of work per pound of slate are then calculated from the weight and thickness of the slate and the number of blows. The resulting figures range from 3.50 to 126.66 .

Toughness or elasticity.-Merriman finds the ultimate deflection in certain Pennsylvania slates, when placed on supports 22 inches apart, to range from 0.270 to 0.313 inch. Certain blue-black slates in Eldorado County, Cal., when split seven to the inch and 18 inches square and fastened solidly at the two ends are said to bend 3 inches in the center without any sign of fracture. $f$ J. F. Williams $g$ tested beams of slate from Rutland and Washington counties, 1 inch square and 10 inches long, with supports 6 inches apart. Bending without breaking was effected by from 770 to 1,200 pounds, and when the supports were placed 3 inches apart by from 1,710 to 2,400 pounds. The great elasticity of the slates of western Vermont and of Northampton and Lehigh counties, Pa., is apparent to any one visiting the shanties where the splitting is done.

Density.or specific gravity.-This is determined in the usual way, by weighing a piece of the slate in and out of water and dividing its weight out by the difference between its weight in and out. All air should first be removed by boiling the piece of slate in distilled water. The specific gravity will be considerably affected by the amount of magnetite or pyrite.

Porosity.-This is best determined by drying, then weighing, then immersing for twenty-four hours and weighing again, in order to ascertain the percentage of water absorbed. Merriman takes a piece 3 by 4 inches, with rough edges, dries it in an oven at $135^{\circ} \mathrm{F}$. for twenty-four hours, cools to the normal temperature of room, weighs, and immerses it for twenty-four hours, and weighs again. His tests of Penn-

$a$ See Bibliog., p. 144. An extended abstract of Merriman's paper is given by Wm. C. Day in part 6 , continued, of Nineteenth Annual Report (pp. 257-263), and on p. 122 of this bulletin the results of his recent tests of 33 specimens of slate are given.

$b$ See Bibliog., p. 145.

c Encycl. Brit., ninth ed., 1887.

$d$ Quoted by Hull; see Bibliography, p. 144 .

$e$ Les ardosières des Ardennes, pp. 192, 193

$f$ California State Mining Bureau, twelfth report of State Mineralogist J. J. Crawford, Sept. 15, 1894, p. 400 .

$g$ See Bibliography, p. 145. 
sylvania slates showed from 0.099 to 0.303 per cent of absorption. Porosity is sometimes roughly indicated by immersing a roofing slate edgewise one-half in water and observing how far the water ascends by capillary attraction. In good slates it ought to rise but very little.

Reverdin and de la Harpe $a$ state that slates are liable to deterioration from the chemical action of gases arising from woodwork beneath the slate, as well as from the action of the atmosphere, and that they are also liable to an increase of porosity by the physical action of changes of temperature and by the unequal conductivity of heat in the direction of cleavage and of grain. They state that the porosity in a fresh slate should be below 0.1 per cent, and after treatment less than 0.2 per cent. Their somewhat elaborate method is this: For determining porosity as produced by acids the slate is treated with 10 per cent cold acetic acid and the flask is made vacuous from time to time. The piece is then washed, dried, weighed, and immersed in diphenylamine in a thick-walled tube 12 by $3 \frac{1}{2}$ centimeters. The tube is exhausted, heated two hours in oil bath at $170^{\circ} \mathrm{C}$., air pressure is restored, and heating continued for four to five hours at $150^{\circ} \mathrm{C}$., after which the test pieces are removed, the diphenylamine wiped off with ether, and the increase in weight taken.

For determining porosity as produced by changes of temperature, the slate is heated in a wrought-iron tube for half an hour to $300^{\circ} \mathrm{C}$, , and the tube is then suddenly cooled by a stream of water for half an hour. This process is repeated twenty-four times, and the slate is then impregnated with diphenylamine and the procedure is as in previous test.

Fresenius is accredited with a method of testing the effect of heat and cold on slate by saturating it with water and putting it for twenty-four hours in a freezing mixture and heating another from $250^{\circ}$ to $350^{\circ}$ for five or six hours and then immersing it in water. The porosity, strength, and elasticity of the pieces so treated should then be tested. Böttinger points out that the greater the porosity of a slate the more damaging is the action of frost likely to be. The effect of frost on the microscopic structure has already been referred to (p. 24).

Hardness, or abrasion.-Merriman has also devised a method of testing the relative hardness of slates by subjecting a piece of determined weight to the action of a grindstone revolved 50 times, the slate being held against it by a lever with a constant pressure of 10 pounds. The loss of weight in the process was then determined. As the softness depends largely upon the amount of quartz and mica a microscopic analysis would also throw light upon this quality.

Corrodibility.--An important quality in roofing slates is their resistance to the acids of the atmosphere, particularly in cities, where gases increase its destructive power. Fresenius in 1868 suggested testing the weathering qualities of a slate by immersing it for three days in dilute sulphurous acid in a closed ressel. At the end of that time poor slates are softened or broken up into thin laminæ or easily fractured, while good ones preserve both their density and hardness.

Merriman for the same purpose prepared a solution consisting of 98 parts of water, 1 part of hydrochloric acid, and 1 part of sulphuric acid. Pieces of slate 3 by 4 inches were carefully weighed, then immersed in the solution for one hundred and twenty hours, then dried for forty hours, weighed, the solution strengthened, and specimen reimmersed for another one hundred and twenty hours, and weighed again. This was repeated once more. The losses in weight ranged from 0 to 2.76 per cent.

Microscopic analysis. - One of the most satisfactory tests of slate is the examination of a thin section of it under the microscope. A cubic inch thus tested will suffice to show the character of the clearage, the presence of false cleavage, if any, the probable durability, or indurability, of the color, as well as the presence of any mineral constituents likely to determine its other qualities. The specimen should be carefully 
selected, so as to fairly represent the general quality of the bed. It should be fresh, unfrozen, and a half inch thick across the cleavage. At least two sections should be prepared-although the more the better-one parallel to the cleavage and another at right angles to it, never diagonal to it. The sections should be exceedingly thin, much more so than ordinary sections of eruptive rocks, and the slide cover should be of the very thinnest kind and should be fastened on with a minimum of lyalsam to admit the use of the highest objectives. Both slides should be examined first in ordinary light then in polarized light, with powers ranging from 140 to 700 and in some cases even 1,100 diameters. The transverse section will show the quality of the cleavage, the false cleavage, if any, and under polarized light whether the specimen is a mica slate or a clay slate by the entire matrix becoming in a mica slate four times dark and four times light in complete rotation. The observer should, however, not be misled by the obscuration of aggregate polarization caused by the abundance of carbonaceous matter or carbonate or hematite. The carbonate, which extinguishes irregularly, is very troublesome. This could be eliminated by the application of $\mathrm{HCl}$ to the bare section and then recovering it. The aggregate polarization may also be obscured by the thickness of the section and the whole analysis thus vitiated. Sections parallel to the cleavage reveal the amount of carbonate and indicate the probable amount of discoloration by exposure. Both sections, unfler incident light, will show pyrite, if any exists.

Chemical analysis.-This, in order to give a correct idea of the composition of the slate, should not be partial, but complete. ${ }^{a}$ Such an analysis should then be compared with complete analyses of the best slates of like color, and before a final conclusion is reached as to the value of the slate its microscopic analysis and the results of the tests of its strength, elasticity, porosity, and corrodibility should be considered in comnection with its chemical analysis. Merriman concludes from six different kinds of tests applied to each of 24 specimens of Old Bangor and Albion (Pennsylyania) slates, as well as from the results of several general chemical analyses, that-

The strongest slate stands highest in weathering qualities, so that a flexural test affords an excellent index of all its properties, particularly if the ultimate deflection and the manner of rupture be noted. The strongest and best shate has the highest percentage of silioates of irom and alumina, but is not necessarily the lowest in carbonates of lime and magnesia. Chemieal analyes give only imperfect conclusions regarding the weathering qualities of slates and do not satisfactorily explain their physical properties. $b$

As the discoloration in slate has been shown to be probably due to the oxidation of the ferrous carbonate $\left(\mathrm{FeCO}_{3}\right)$, one of the chief ohjects of a chemical analysis should be to show ity amount or absence, but this is just what a chemical analysis can not do with so complex a rock.

Hutchins finds that the presence of chlorite minerals can be detected by heating the slate to dull redness, thus dehydrating and discoloring those minerals, then preparing a thin section of the slate so treated and comparing it with sections of the normal rock. $c$

The most decisive of all these tests are probably those for strength and toughness, as applied by Merriman, and the microscopic analysis.

It should be arded that shearing, compression, and expansion tests of slate have been made at the United States Arsenal at Watertown, Mass.

a See, on the advantage of complete analysis, Prineiples and methods of analysis applied to silicate rocks, by W. F. Hillebrand, Bull. U. S. Geol. Survey No. 148; A nalyses of roeks and analytical methods, Clarke and Hillebrand, pp. 1- $-64,1897$.

$b$ Merriman. See Bibliography, p. 144 .

c Hutchins, Clays, shales, and slates. See Bibliography, p. 140. 


\section{TECHNICAL DESCRIPTION OF A SLATE QUARRY.}

The following outline of a description of a slate quarry for economic purposes is proposed as covering the features of practical geological and economic importance, aside from the ordinary statistical matters as to amount and value of product, number of employees, etc.:

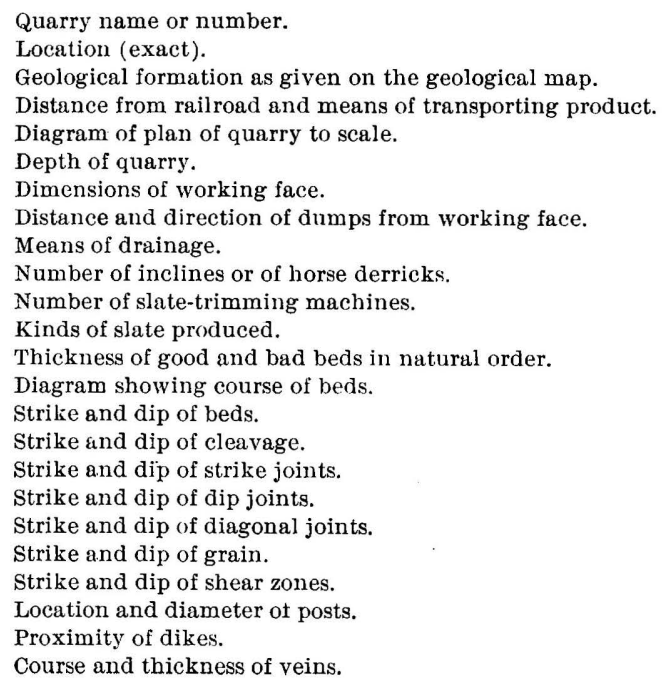




\title{
PART II.-SLATE DEPOSITS OF THE UNITED STATES.
}

ARIZONA.

\author{
By T. Nelson Dale.
}

A specimen of roofing slate recently received from Arizona by Dr. David T. Day, of the division of mineral resources of the United States Geological Survey, came from a deposit about $6 \frac{1}{2}$ miles north of Phoenix, which is said to measure from 800 to 1,000 feet in width and about 5,000 feet in length. Its examination has yielded the following results:

It is bluish gray with a lustrous surface, marked by two sets of minute wrinkles that lie at right angles to each other, a coarser set numbering from 25 to 40 per inch and a finer one numbering many more. The slate breaks along the finer set much more readily than along the coarser set. It has a marked argillaceous odor, shows considerable pyrite on the sawn edge, contains but little magnetite, does not effervesce in cold dilute hydrochloric acid, is sonorous, and has a fair grade of fissility.

Under the microscope this slate shows a matrix $a$ consisting of muscovite (sericite) with a brilliant aggregate polarization. $a$ Cleavage and bedding foliations are parallel, but are crossed by two incipient slip-cleavages (see p. 24 and Pls. VI, XI, $A$ ), the plications of which have not resulted in fractures, but which give the slate a somewhat schistose structure. The finer of these slip-cleavages has from 100 to 150 plications to the inch. There is considerable quartz, which appears to be mostly secondary. The conspicuous feature, however, is the great abundance of lenses and particles of pyrite and hematite. In the cross sections these measure from 0.0043 to 0.043 millimeters in length by from 0.002 to 0.008 millimeters in wilth and number. about 800 per square millimeter. $b$ In parallel section they have irregular angularroundish outlines.

There are also large plates of muscovite, a few crystaly of tourmaline, a few lenses or decomposed crystals of (?) up to 0.0425 by 0.025 to 0.075 millimeters and considerable rutile in very minute prisms. No carbonate detected.

The constituents of this slate, arranged in descending order of abunclance, appear to be muscovite (sericite), quartz, pyrit, hematite, kaolin, magnetite, rutile, and tourmaline.

If properly cut with reference to the direction of weakness this may prove a serviceable slate, but false cleavage is generally objectionable. In this case the false cleavages are, however, only incipient.

ARKANSAS.

By Eowrn C. Eскеi.

\section{LOCATION AND CHARACTER OF DEPOSITS.}

Location-The slate deposits of Arkansas are included in an area of Ordovician rocks in the west-central portion of the State. This area is about 100 miles in its greatest dimension from east to west, and varies from 12 to 20 miles in breadth from north to south. The towns of Little Rock, Benton, Malvern, Hot Springs, and Mena 
are all located just outside the boundaries of this Ordovician area, as will be seen from an examination of Pl. VIII, which gives the outlines of the district. Within this district deposits of roofing slate occur at numerous localities, but outside of its limits no slate can reasonably be expected to occur in Arkansas. Prospecting should be confined, therefore, to the area shaded in Pl. VIII.

This should not be construed as meaning that all this area is underlain by deposits of roofing slate, for such is by no means the case. On the contrary, workable roofing slate deposits make up only a small portion of the shaded area, the remainder being occupied by sandstones and shales.

Description of deposits. - Within the district noted roofing slates have been worked in a small way at several points near Hot Springs, Garland County, for a number of years. None of the workings, however, has been extensive enough to give a definite idea of the commercial possibilities of the deposits.

During the last few years a new slate area has been exploited in western Arkansas, the principal deposits here being in the counties of Polk and Montgomery. Here black, gray, red, and greenish slates occur in abundance, and a number of companies have been organized to work various properties. In the spring of $1905 \mathrm{I}$ spent a few days in this area, visiting most of the deposits which had been opened. This area is shown in Pl. IX, where a number of quarry locations are indicated. The only quarries in operation at that time were those of the Southwestern Slate Company, at Slatington, about 20 miles southwest of Mount Ida, Montgomery County. Both red and black slates occur on the property of this company.

In a report made recently Buckley gives the following general section:

Feet.

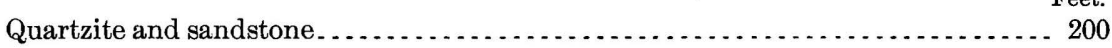

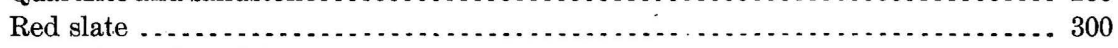

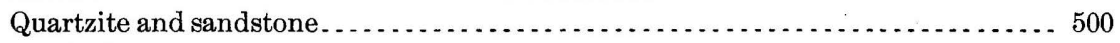

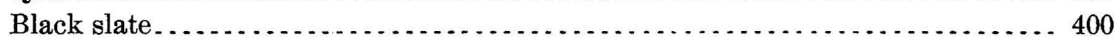

The black slate quarry of this company is located on Crooked Creek, in section 34, T. 3 S., R. $27 \mathrm{~W}$. The slate here strikes N. $70^{\circ}$ E. and dips $25^{\circ}$ N. It is a finegrained, deep black slate, and seems excellent for either roofing or mill slate. A few berls of rock (sandstone) are included in the section, but altogether a thickness of about 400 feet of black slate is exposed in the quarry along Crooked Creek.

Nearer to the company's office, at Slatington, red slates are quarried in section 33 , T. 3 S., R. 27 W. The slate here strikes N. $30^{\circ} \mathrm{W}$. and dips $20^{\circ}$ NE. The mill contains one saw, taking an 8 by 5 foot slab; one planer, taking an 8 by 4 foot slab, and one 12 -foot rubbing bed.

In 1904 the Kansas City Slate Quarrying Company opened a quarry in the northwest quarter of section 12 , T. 3 S., R. 28 W. The cleavage here strikes N. $80^{\circ} \mathrm{W}$. and dips $45^{\circ} \mathrm{N}$., and the bedding is apparently parallel to the cleavage. The slate is badly jointed near the surface. Most of that exposed is green, with occasional red streaks and much pyrite. The slate on the dump has disintegrated very badly on weathering, and is really hardly more than a clay shale.

The Gulf Slate Company has an opening about 20 feet square and 30 feet deep on the southwest quarter of section 9, T. 3 S., R. 28 W. The cleavage here strikes N. $65^{\circ} \mathrm{E}$. and dips $35^{\circ} \mathrm{N}$. The slate exposed in this shallow pit is mostly red. It is better than that last noted, but is rather soft.

A red slate of good grade is exposed in S. 17, T. 3 S., R. 28 W., with cleavage striking N. $10^{\circ} \mathrm{E}$. and dipping $40^{\circ} \mathrm{W}$.

Black slate of good quality is shown just north of Little Missouri Creek, in S. 3, T. 4 S., R. $28 \mathrm{~W}$. The cleavage strikes N. $60^{\circ}$ E. and dips $10 \mathrm{~N}$.

On Danville's property in S. 28, T. 3 S., R. 28 W., a gray slate is exposed. This is a hard, durable slate, but is badly jointed near the surface. The bedding strikes N. $30^{\circ} \mathrm{W}$. and $\operatorname{dips} 30^{\circ} \mathrm{SW}$. 


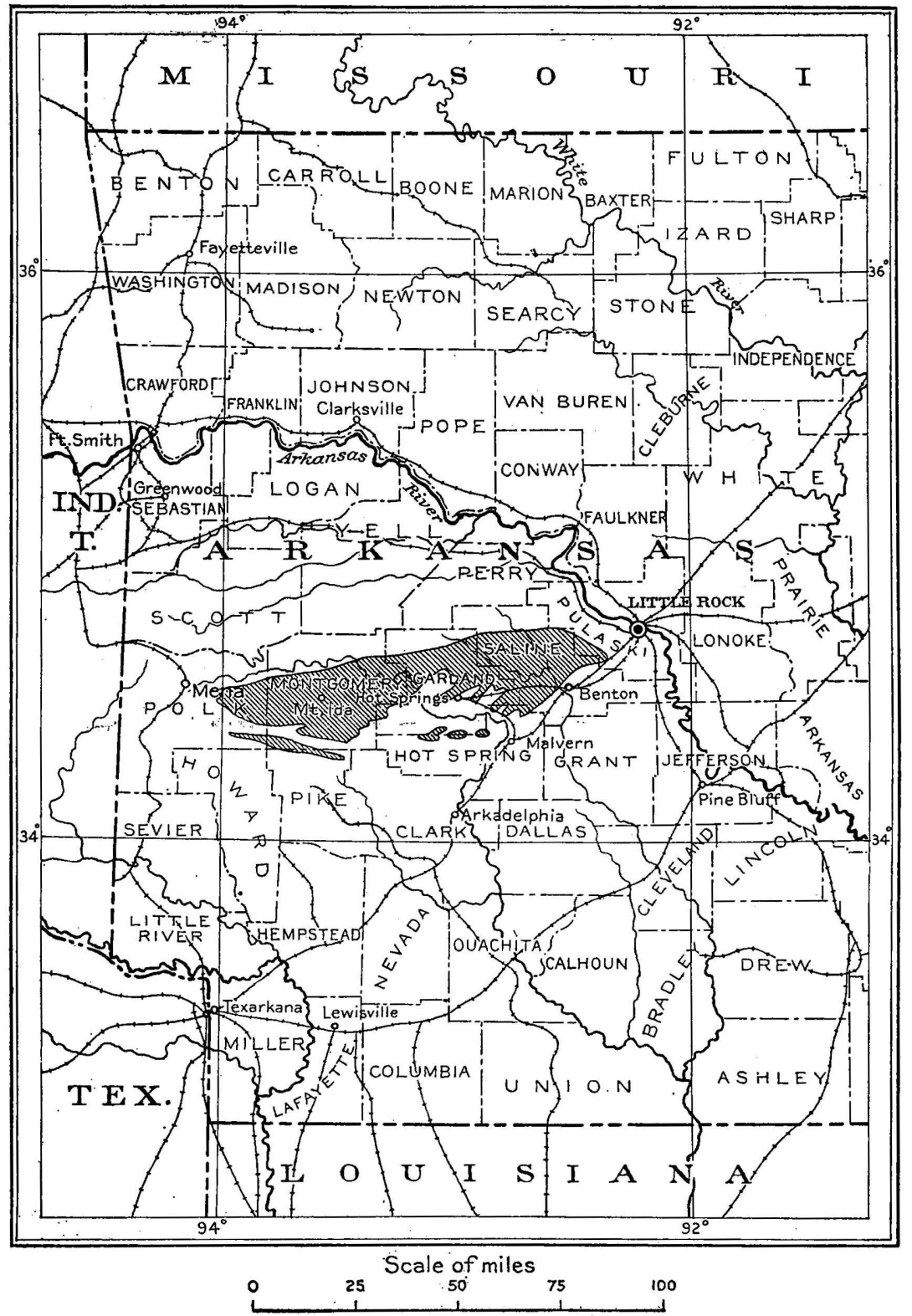

MAP SHOWING ARKANSAS SLATE AREA. 

Stratton and Kelley's property in S. 29, 'T. 3 S., R. 28 W., shows a red slate striking $\mathrm{N} .70^{\circ}$ and dipping $43^{\circ} \mathrm{N}$. In the northeast quarter of the same section the National Slate Company has an opening.

Black and gray slates in large smooth slabs are exposed on the Brennan and McElwen property in the northeast quarter of S. 30, T. $3 \mathrm{~S} .$, R. $28 \mathrm{~W}$. The cleavage in these outcrops strikes $\mathrm{N} .70^{\circ} \mathrm{W}$. and dips $13^{\circ} \mathrm{N}$.

The Barden quarry in S. 25, T. 3 S., R. 28 W., shows good black slate, striking N. $65^{\circ} \mathrm{E}$. and dipping $20^{\circ} \mathrm{N}$.

Chemical composition of Arkansas slates.-The following analyses of Arkansas roofing slates are fairly representative of the composition of these materials:

Analyses of slates, Montgomery County, Ark.

[Analyst, W. G. Waring.]

\begin{tabular}{|c|c|c|c|c|c|c|c|}
\hline & 1. & 2. & 3. & 4. & 5. & 6. & 7. \\
\hline Silica $\left(\mathrm{SiO}_{2}\right) \ldots \ldots \ldots \ldots$ & 66.16 & 68.79 & 69.04 & 69.07 & 67.90 & 64.00 & 63.22 \\
\hline Alumina $\left(\mathrm{Al}_{2} \mathrm{O}_{3}\right) \ldots \ldots \ldots \ldots$ & 8.62 & 14.26 & 12.66 & 11.40 & 10.42 & 11.59 & 16. 76 \\
\hline Ferric oxide $\left(\mathrm{Fe}_{2} \mathrm{O}_{3}\right) \ldots \ldots \ldots \ldots \ldots \ldots$ & 9.04 & 5.90 & 8.55 & 7.66 & 6.22 & 13.71 & 9.54 \\
\hline Ferrous oxide $(\mathrm{FeO}) \ldots \ldots \ldots \ldots \ldots \ldots \ldots \ldots$ & 3.44 & 1.16 & 1.30 & 1.04 & …… & & \\
\hline $\operatorname{Iime}(\mathrm{CaO}) \ldots \ldots \ldots \ldots \ldots \ldots \ldots \ldots \ldots \ldots \ldots \ldots \ldots$ & 1.77 & 1.40 & 1.75 & 1.56 & 3.17 & 1.56 & 1. 75 \\
\hline Magnesia $(\mathrm{MgO}) \ldots \ldots \ldots .$. & .78 & 1.43 & 1.87 & 3.14 & 4. 34 & 2.03 & 1.52 \\
\hline Potash $\left(\mathrm{K}_{2} \mathrm{O}\right) \ldots \ldots \ldots \ldots \ldots \ldots \ldots \ldots$ & 4.96 & 3.09 & 2.98 & 3.88 & 4.11 & 1.36 & 1.43 \\
\hline Soda $\left(\mathrm{Na}_{2} \mathrm{O}\right) \ldots \ldots \ldots \ldots \ldots \ldots \ldots$ & .64 & .09 & .09 & .96 & .69 & .64 & .70 \\
\hline Sulphur in $\mathrm{SO}_{3} \ldots \ldots \ldots \ldots \ldots \ldots \ldots \ldots$ & .08 & .44 & .06 & .02 & .06 & .05 & .05 \\
\hline Sulphur in $\mathrm{FeS}_{2} \ldots \ldots \ldots \ldots \ldots \ldots \ldots \ldots \ldots \ldots \ldots$ & .02 & .01 & .01 & .01 & .01 & .04 & .03 \\
\hline 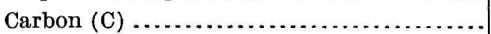 & 2.10 & 2.01 & Tr. & $\ldots .$. & 1.78 & 4.03 & 3.70 \\
\hline Carbon dioxide $\left(\mathrm{CO}_{2}\right) \ldots \ldots \ldots \ldots \ldots \ldots$ & .09 & .11 & .72 & .11 & .01 & .01 & .01 \\
\hline 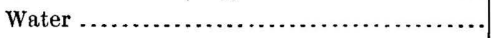 & .18 & .47 & .84 & .24 & .23 & .57 & 1.01 \\
\hline
\end{tabular}

1. Green slate, quarry No. 2 .

2. Red slate, quarry No. 2.

3. Red slate from State House Cove.

4. Hard red slate from State House Cove.

5. Green slate from State House Cove.

6 . Black slate from west end of Crooked Creek vein.

7. Black slate from Crooked Creek Falls.

\section{MICROSCOPIC ANALYSES OF ARKANSAS SLATE.}

\section{By T. Nelson Dale.}

The microscopic analyses of Arkansas slates published in 1904, Bull. U. S. Geol. Survey No. 225, p. 414, have been revised and are here repeated and supplemented by several new ones of specimens collected by Mr. Eckel during his recent visit to the quarries of that State.

Black slate from Mena, near Big Forks. This is a pure black slate, which to the unaided eye has an exceedingly fine texture and a remarkably smooth cleavage surface with a slight luster. It is both carbonaceous (or graphitic) and magnetitic; does not effervesce with cold dilute hydrochloric acid, is very sonorous, and very fissile. Under the microscope this slate shows a matrix of muscovite (sericite), with a very brilliant aggregate polarization and an unusually fine texture and great homogeneity. Quartz grains are few and not over $0.01 \mathrm{~mm}$. in diameter. Rutile needles unusually minute. Many opaque particles of irregular shape, some of which are pyrite, others magnetite, and some coaly or graphitic matter. No carbonate.

The constituents, arranged in descending order of abundance, appear to be muscovite (sericite), carbonaceous or graphitic matter, quartz, pyrite, magnetite, and rutile. 
This is a very superior roofing slate, with a remarkably fine cleavage and not liable to discolor on exposure, but its strength and its behavior under frost should be tested.

Dark-reddish slate from Mena, near Big Forks. In color this slate is somewhat darker than the "red" slate of New York. To the unaided eye it has a minutely granular texture and a roughish, speckled, almost lusterless surface. Contains very little magnetite; does not effervesce with cold dilute hydrochloric acid, is sonorous, splits readily, and has some argillaceous odor. Under the microscope it shows a matrix of muscovite (sericite), with brilliant aggregate polarization, quartz grains ranging up to $0.025 \mathrm{~mm}$. muscovite and chlorite scales, and abundant hematite in minute dots. There are also rhombs, from 0.1 to $0.2 \mathrm{~mm}$., of chlorite and rhodochrosite, probably pseudomorphs after? No other carbonate.

The constituents, arranged in descending order of abundance, appear to be muscovite (sericite), hematite, kaolin, quartz, chlorite, rhodochrosite?, and magnetite.

This slate compares favorably in texture with the New York "red" slate.

Reddish slate from Mammoth red and Lost Hannah beds (exact locality not given). Color lighter than above, but not quite so red as the New York slate. To the unaided eye has a fine texture and a fine cleavage surface, but no luster. Contains very little magnetite; does not effervesce with cold dilute hydrochloric acid, is sonorous and fissile, has some argillaceous odor.

Under the microscope it shows a matrix of muscovite (sericite), with brilliant aggregate polarization, quartz grains up to $0.03 \mathrm{~mm}$., muscovite and chlorite scales, abundant hematite pigment, and no carbonate.

The constituents, arranged in descending order of abundance, appear to be muscovite (sericite), hematite, kaolin, quartz, chlorite, and magnetite.

This is a finer and softer slate than the dark red, and should be tested for strength and frost resistance.

Greenish-gray slate from Mena. In color this resembles the "sea-green" slate of Vermont. To the unaided eye it has a fine texture, a roughish cleavage surface, and a waxy luster; does not show pyrite on sawn edge, contains very little magnetite; does not effervesce with cold dilute hydrochloric acid, and is somewhat sonorous.

Under the microscope it shows a matrix of muscovite (sericite), with a brilliant aggregate polarization and is of very fine texture and homogeneity, but the cleavage is crossed at an angle of $13^{\circ}$ by a very close bedding foliation and also by an obscure slip or "false" cleavage at about $40^{\circ}$. Contains very few and very minute quartz grains, no carbonate, several pseudomorphic rhombs of chlorite $0.08, \mathrm{~mm}$., and has a slight argillaceous odor.

The constituents, arranged in descending order of abundance, appear to be muscovite (sericite), quartz, kaolin, chlorite, and magnetite.

The two extra foliations are likely to prove directions of weakness.

Light-greenish slate from Mammoth red bed, locality not designated. This is more greenish than the above, to the unaided eye has an exceedingly fine texture and a very fine, almost lusterless cleavage surface; shows pyrite on sawn edge, contains a little magnetite; does not effervesce with cold dilute hydrochloric acid, is sonorous, very fissile, and has a slight argillaceous odor.

Under the microscope it shows a matrix of muscovite (sericite), with a brilliant aggregate polarization and great evenness of texture. A very minute bed of quartz grains, chlorite, and muscovite lies in the cleavage, which is, therefore, the bedding also. The grain is indicated by the transverse position of some of the muscovite scales. Quartz not very abundant, but occurs in grains up to $0.037 \mathrm{~mm}$. Rutile needles abound from 0.0028 by 0.0009 up to 0.014 by $0.0014 \mathrm{~mm}$. Muscovite and chlorite scales occur, the latter producing the green color. There are some opaque granules (limonite? and pyrite), occasional lenses, $0.14 \mathrm{~mm}$. long, of a central mass (probably rhodochrosite), with secondary muscovite at both ends. No other car. bonate. Shows a number of tourmaline prisms up to 0.025 by $0.008 \mathrm{~mm}$. 


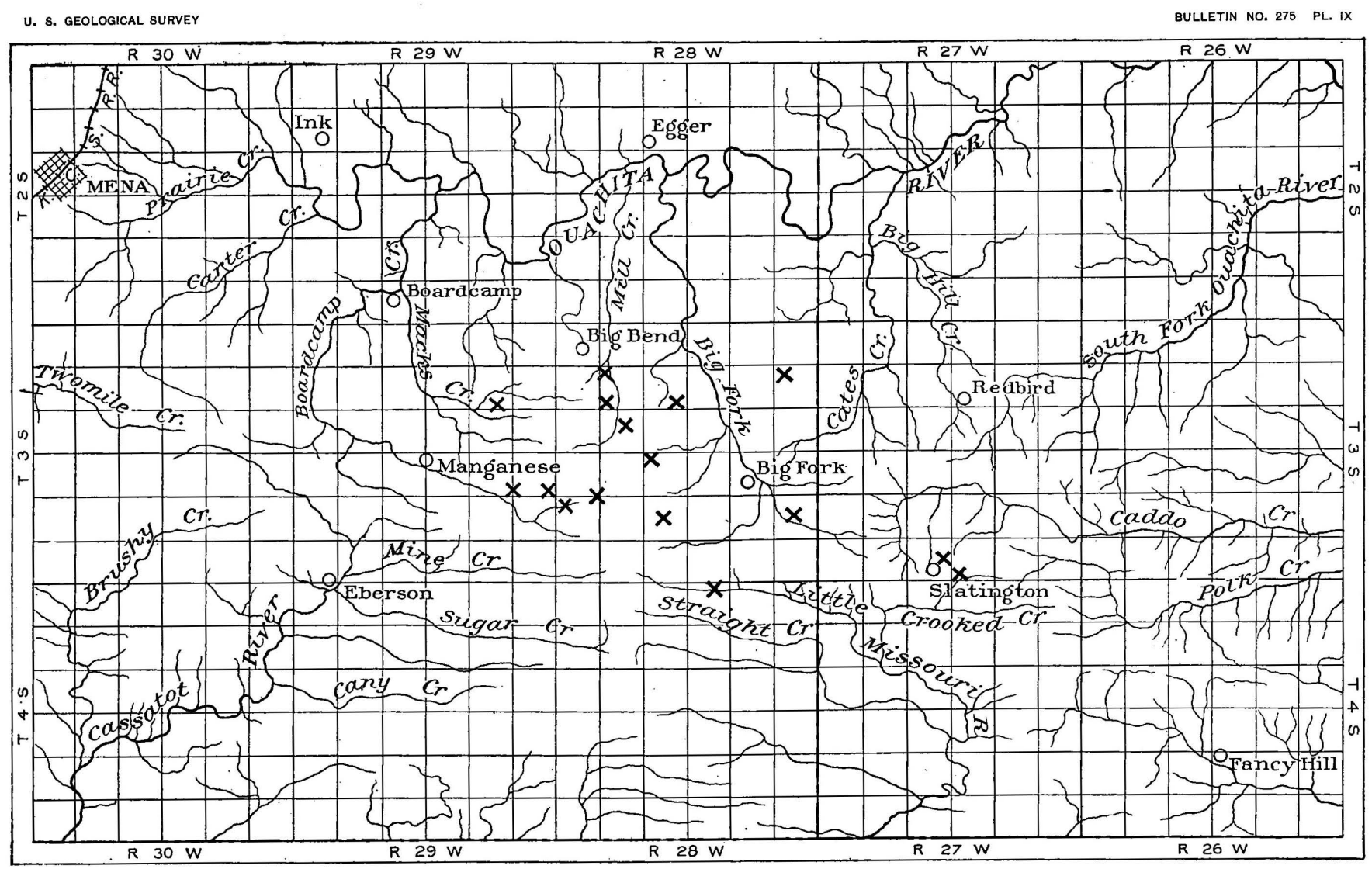

SKETCH MAP SHOWING LOCATION OF SLATE DEPOSITS OF MONTGOMERY AND POLK COUNTIES, ARKANSAS. 

The chief constituents, arranged in the descending order of abundance, appear to be muscovite (sericite), quartz, kaolin, chlorite, rutile, pyrite, magnetite, and tourmaline.

This is a very superior siate on account of its fissility, color, and freedom from carbonate, but its strength and resistance to frost should be tested.

Very dark bluish gray slate from sec. 25, T. 3 S., R. 29 W. (Specimen collected by Mr. E. C. Eckel.)

To the unaided eye this slate has a fine texture and a smooth cleavage surface with a little luster, and shows a litt'e pyrite on the sawn edge. It contains very little magnetite, considerable carbonaceous or graphitic matter, does not effervesce with cold dilute hydrochloric acid, is sonorous, and has a high grade of fissility. Under the microscope it shows a fine-textured matrix of muscovite (sericite) with good aggregate polarization, but somewhat obscured by carbonaceous matter. Quartz is not abundant, the grains measuring up to 0.047 by $0.02 \mathrm{~mm}$. Pyrite spherules, measuring up to $0.008 \mathrm{~mm}$. in diameter, number about 120 per square millimeter. There are rutile needles but no carbonate.

The chief constituents, arranged in order of decreasing abundance, appear to be muscovite (sericite), quartz, pyrite, carbonaceous or graphitic matter, and rutile.

This slate has absence of carbonate in its favor. It is not so fine textured or so fissile as that described on page 53 , but may prove more durable.

Light-gray slate with a slightly greenish tinge from sec. 30 , T. 3 S., R. 28 W. (Specimen collected by Mr. E. C. Eckel.) To the unaided eye this has a fine texture, but a lusterless, roughish surface, and shows a little pyrite on the sawn edges. It contains an insignificant amount of magnetite but no carbonaceous or graphitic matter, does not effervesce with cold dilute hydrochloric acid, and has an argillaceous odor and a fair degree of fissility and sonorousness.

Under the microscope it shows a fine-textured matrix of muscovite (sericite) with brilliant aggregate polarization, containing not abundant quartz grains, measuring up to $0.03 \mathrm{~mm}$., scales of chlorite and of muscovite transverse to cleavage, some pyrite cubes up to $0.063 \mathrm{~mm}$. (generally with a rim of secondary quartz) passing into limonite and staining the matrix. Rutile needles abound.

The chief constituents, arranged in decreasing order of abundance, appear to be muscovite (sericite), quartz, chlorite, kaolin, pyrite, rutile, and limonite, with accessory magnetite.

Whether the limonitic staining from the decomposition of the pyrite will produce any appreciable discoloration in the course of years can be determined only by experiment.

Very dark-gray spangled slate from quarry operated by the Southwestern Slate Manufacturing Company. (Specimen collected by Mr. E. C. Eckel.) To the unaided eye this has a coarsish texture and a roughish, almost lusterless surface, spangled with minute scales of mica, shows pyrite on sawn edges, contains very little magnetite and little carbonaceous matter, does not effervesce with cold dilute hydrochloric acid, is somewhat sonorous, tolerably fissiie, and has a slight argillaceous odor.

Under the microscope it shows a fine-textured matrix of muscovite (sericite) with brilliant aggregate polarization, containing roundish and angular grains of quartz of variable and large size, even up to 0.27 by $0.17 \mathrm{~mm}$. ; also a few of plagioclase feldspar, scales of muscovite and biotite up to $0.2 \mathrm{by} 0.1 \mathrm{~mm}$., some lenses of carbonate up to 0.4 long, a few grains of tourmaline, and lenses of secondary quartz. There is a faint incipient false cleavage, not apparent, however, in the hand specimen.

The chief constituents of this slate, arranged in order of decreasing abundance, appear to be muscovite (including sericite), quartz, carbonate, pyrite, carbonaceous matter, and kaolin, with accessory biotite, plagioclase, tourmaline, and magnetite.

This slate combines some of the features of a metamorphic graywacke or grit with those of a mica-slate. It is inferior to the dark bluish-gray slate described above.

Bull. 275-06-5 


\title{
CALIFORNIA.
}

\author{
By Edwin C. ECKel.
}

Location and general relations.-Though roofing slate has at different times been quarried on a small scale in other parts of California, the only important slateproducing area in the State is located in Eldorado County. The quarries which have been opened in this district are located along a line running about N. $15^{\circ} \mathrm{W}$. from Placerville, at distances of 1 to 6 miles from that town. The location and geographic and geologic relations of the slate deposits and quarries can best be understood by reference to the maps included in the Placerville folio of the United States Geological Survey. The workable roofing-slate deposits of this district occur in a belt of the Mariposa slates, of late Jurassic or early Cretaceous age. The quarries which have been opened are all situated near the western boundary of this belt of Mariposa slates, where it is bordered by a large area of diabase. This diabase, according to Lindgren and Turner, is "of the age of the Mariposa slates, or older." A number of linear areas of amphibolite occur in the Mariposa slates. These amphibolites are described as being derived from diabase or gabbro. They are in part altered to serpentine.

Previous work on the slate deposits. - The Placerville folio, No. 3, United States Geological Survey, published in 1894, contains the results of detailed geologic work by Lindgren and Turner in the area in which the roofing-slate deposits occur. At that date the roofing-slate industry had not assumed its present importance, though all the quarries now worked had then been opened. The existence of roofing-slate deposits is noted in the text of the folio, and the locations of the quarries are indicated on the map showing the economic geology of the area. No reference is made to the "green slates," or to the dikes cutting the Eureka quarry.

Excellent though brief descriptions of the different quarries and of the condition of the slate industry at various dates are to be found in the reports of the State mineralogist of California, particularly in the eighth and twelfth reports. The geologic relations of the slate-producing areas are shown in Pl. X.

At present the most important quarry is that of the Eureka Slate Company, and this is now being worked on a large scale. This quarry is at Slatington, about onehalf mile southwest of Kelsey.

Structural relations in Eureka quarry. - The cleavage planes of the slates in the Eureka quarry strike N. $25^{\circ} \mathrm{W}$. The dip of the cleavage is practically vertical, with slight local variations to $80^{\circ} \mathrm{E}$. or $80^{\circ} \mathrm{W}$. The upper weathered beds in the quarry are overturned by local pressure so as to give dips of $40^{\circ}$ to $60^{\circ}$ to the east or west, according to local conditions. This overturning is evidently due merely to the weight of the overlying soil and decomposed slate, and the effects are shown only for a depth of from 3 to 15 feet. It is of interest, however, as a warning against accepting dip readings taken from surface beds of the slate.

The slate body shows rather frequent, but narrow, "ribbons." These ribbons are bands (from one-sixteenth to one-half inch thick usually, but occasionally as thick as 2 inches) of material differing in composition from the mass of the slate. They are in general more siliceous than the normal slate, and do not furnish merchantable material. Their geologic interest arises from the fact that they represent differences of original sedimentation. The plane of the ribbons in a slate quarry is, therefore, the plane of original bedding. In the Eureka quarry, and, indeed, throughout the roofing-slate belt, the plane of original bedding seems to be usually within $10^{\circ}$ of the plane of slaty cleavage.

The slate mass is cut by a series of joints parallel to the "grain" of the slates, striking N. $55^{\circ} \mathrm{E}$. and dipping from $70^{\circ}$ to $80^{\circ} \mathrm{NW}$. Joints across the "grain" of 


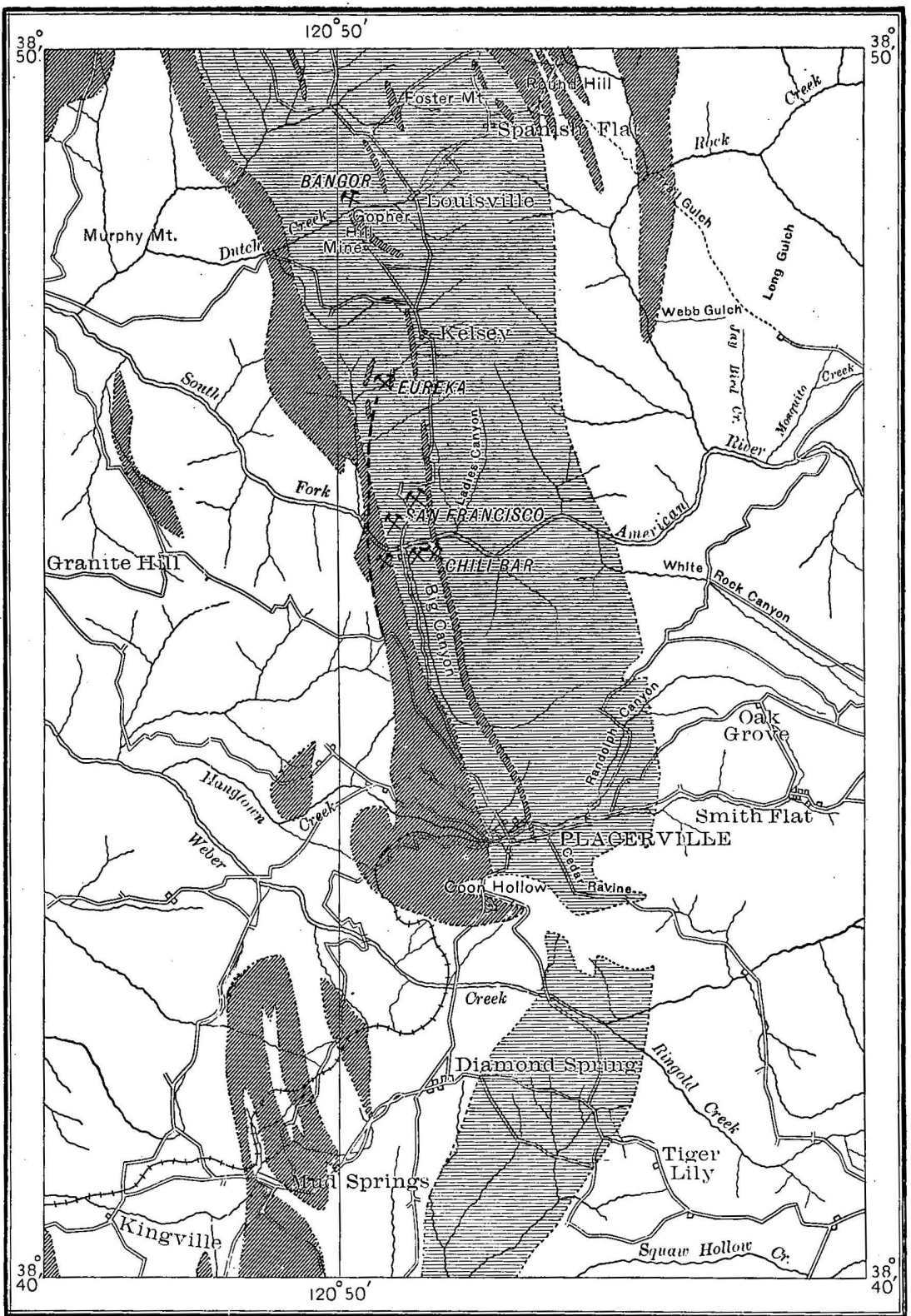

GEOLOGIC MAP OF PLACERVILLE SLATE DISTRICT, CALIFORNIA.

Scale

\begin{tabular}{lllll}
0 & 1 & 2 & 3 & 4 \\
\hline
\end{tabular}
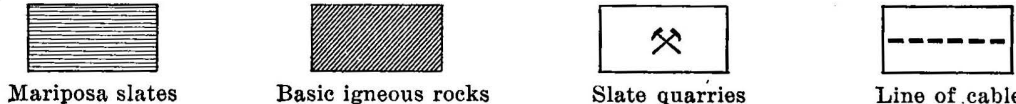

Line of cable 

the slate, which would be practically horizontal, do not occur in this quarry, but many of the thin quartz seams occupy this position.

Quartz and calcite occur in thin layers, filling joint spaces and occasionally cleavage spaces. Pyrite also occurs in very much flattened nodules, which were apparently parallel to the original bedding.

Character of the normal slate.-The mass of the Eureka quarry product is a dense, deep-black slate, splitting very finely and regularly, with a smooth glistening surface, much like that of the Bangor and Lehigh slates of Pennsylvania. The frequency of the ribbons and of the pyrite nodules prevents the slate from being serviceable as mill stock, but as a roofing material it is excellent.

A specimen of the black slate, free from ribbon, was selected for analysis in the laboratory of the United States Geological Survey. The results of this analysis, by Mr. W. T. Schaller, follow:

Analysis of black slate, Eureka quarry, Slatington, Cal.

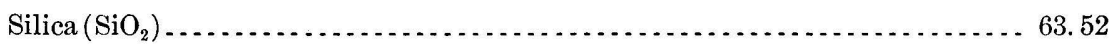

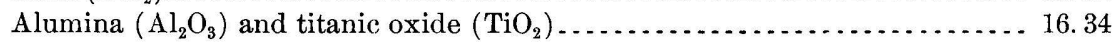

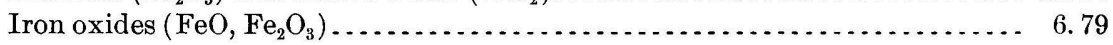

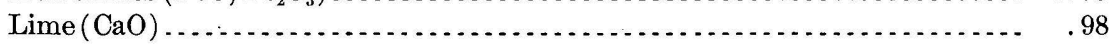

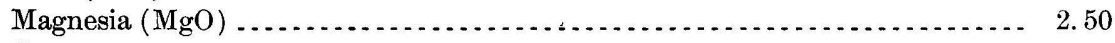

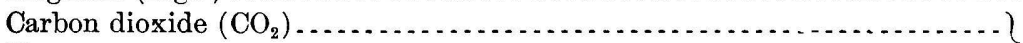

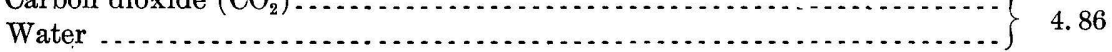

Prof. T. Nelson Dale has reported as follows on a sample of this slate:

This slate is very dark gray. To the unaided eye it has a fine texture and a smooth and lustrous cleavage surface. It contains considerable carbonaceous or graphitic matter but extremely little magnetite. The sawn edges show pyrite and lenses, and streaks of lighter gray material. There is no effervescence in cold dilute hydrochlóric acid. It is sonorous and has a high grade of fissility.

Under the microscope it shows a matrix of muscovite (sericite) with a brilliant aggregate polarization and a general evenness of texture, interrupted, however, by lenses up to about $3 \mathrm{~mm}$. long by about one-half mm. wide, consisting chiefly of quartz fragments (surrounded by a rim of radiating secondary quartz) with muscovite scales, plates, and rhombs of carbonate, and rarely a grain of plagioclase. These lenses have their long axes parallel to the cleavage, but in sections parallel to it some of them have such irregular outline and are so large as to appear like minute beds. The matrix contains many quartz fragments, measuring up to 0.09 by $0.03 \mathrm{~mm}$., much less carbonate than the lenses, muscovite scales, chlorite scales, a little pyrite in spherules and crystals, carbonaceous or graphitic matter, rutile needles, a few grains of tourmaline, and rarely one of zircon.

The main constituents of this slate, arranged in order of decreasing abundance, appear to be muscovite (sericite), quartz, chlorite, carbonate, pyrite, carbonaceous matter or graphite, rutile, and magnetite, besides accessory tourmaline and zircon.

This ought to prove a serviceable slate. It will be noticed that carbonate, although present, is insufficient to produce effervescence.

Eureka quarry green slate. ${ }^{-A}$ A band of green slate several feet wide crosses the Eureka quarry. On examination it is found that the borders of this band are not parallel to the "ribbon" of the black slate. The green band can not, therefore, be interbedded with the black slates. The probability that it represents a dike of massive igneous rock which has been changed to a slate by.pressure subsequent to its intrusion is strengthened when the chemical composition of the green slate is considered. Two analyses of the green slates are presented on the next page. The first is of a sample selected by the writer and analyzed in the laboratory of the United States Geological Survey by Mr. W. T. Schaller; the second was given by Mr. C. H. Dunton, manager of the Eureka quarry, but the name of the analyst is unknown. As the analyses show a close agreement in essential features, it is probable that they are fairly representative of the composition of the green slates, and that their aver-

a For a more detailed discussion of this interesting "igneous slate" the reader is referred to the paper by the writer in the Journal of Geology, vol. 12, 1904, pp. 15-29. 
age, which is given in the third column of the table, may be regarded as typical of this interesting and apparently unique type of roofing slate.

Analyses of ignemus green slate, Eureka quarry, Slatington, Cal.

\begin{tabular}{|c|c|c|c|}
\hline & (1) & $(2)$ & $\begin{array}{l}\text { Aver- } \\
\text { age. }\end{array}$ \\
\hline Silica $\left(\mathrm{SiO}_{2}\right) \ldots \ldots \ldots \ldots$. & 45.15 & 47.30 & 46.22 \\
\hline 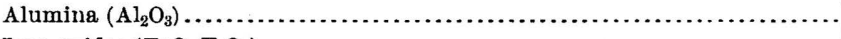 & 16.33 & 15.53 & 15.93 \\
\hline 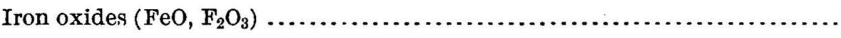 & 8.42 & 8.00 & 8.21 \\
\hline 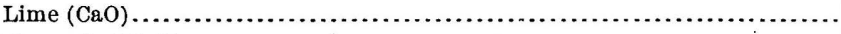 & 6.42 & 7.83 & 7.12 \\
\hline 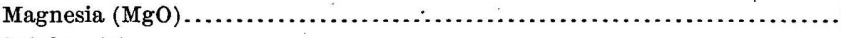 & 8.72 & 7.86 & 8.29 \\
\hline 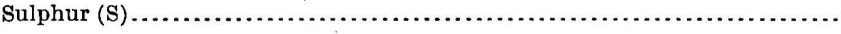 & $(a)$ & .12 & .12 \\
\hline 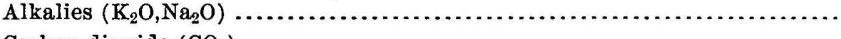 & (a) & 3.17 & 3.17 \\
\hline 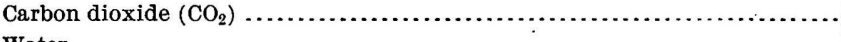 & 11.28 & 9.92 & 10.60 \\
\hline 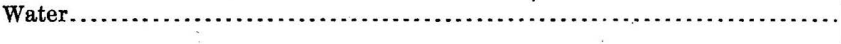 & & & \\
\hline
\end{tabular}

$a$ Not determined.

These analyses have been compared $a$ with a series of 36 analyses of American roofing slates derived from clays by pressure, and remarkable differences in composition are apparent. The green slate, on the other hand, approximates closely in composition to certain "basic" igneous rocks of the district, and it is probable that it was derived from a gabbro or similar rock.

The "green slate" is in reality grayish green in color. It splits readily, though with not so smooth a surface as the black slate. It stands punching and trimming well, and is sufficiently strong for roofing use. Considering its origin and composition it is probable that it will be a highly durable slate, holding its color well. At present it is sold entirely for trimming and lettering on black slate roofs, for which purpose it is particularly well adapted, giving a strong but pleasant color contrast.

Chili. Bar Slate Company quarry.-This quarry is located about 3 miles north of Placerville, in sec. 36, T. 11 N., R. 10 E., on the south side of the South Fork of American River, a few hundred yards east of the Placerville-Kelsey stage road.

This is the oldest quarry in the district, having been opened about twenty years ago. It has been shut down since 1897 .

Several openings were made in a bluff forming the river bank at this point. In the easternmost of these openings, which is about 40 feet high and 30 feet wide, a rather poor slate with irregular joints is shown. The cleavage strikes N. $20^{\circ} \mathrm{W}$, and dips $75^{\circ} \mathrm{E}$. The westernmost opening is small, with a tunnel which was apparently run in on a band of better slate. The slate piled in the yard has kept its color fairly well.

It seems possible that this quarry may be flooded at high water. Both it and the one next mentioned (San Francisco quarry) are badly located, having no large dumping area available near the quarries. Neither quarry has gone deep enough to get really good slate, which might have been found at a greater depth.

San Francisco Slate Company quarry.-This quarry is located in T. 11 N., R. 10 E., within a quarter mile of that of the Chili Bar Slate Company, but on the north side of the river and west of the Placerville-Kelsey road. The principal opening was located about 600 feet north of the river, at an elevation of 150 feet above its bank. A tramway led down to the dressing yards, which were situated at the river bank.

The cleavage of the slates in the large opening strikes about N. $30^{\circ} \mathrm{W}$., and has an almost vertical dip. No slate has been quarried here since 1897. A large stock of trimmed slates is still piled in the dressing yard, and many of these have already discolored badly. 
Transportation and market.-The Eldorado County slates have practically no competition on or near the Pacific coast, while the Eureka quarry has recently placed large shipments in Hawaii and Guam. Until recently the principal problem has been the transportation of the slates from the quarry to the railroad. This was formerly done by wagon hauling over a 6-mile stretch of very hilly road. During the last season, however, the Eureka Slate Company has installed an aerial tramway system from its quarry to a point near Placerville. This tramway is an engineering feat of no mean order, the crossing of the South Fork of American River being the principal difficulty encountered.

Production of roofing slate in California.-The following table, compiled from figures given in various volumes of Mineral Resources of the United States, shows the amount and value of California slate production for a number of years:

California production of roofing slate, 1890-1901.

\begin{tabular}{|c|c|c|c|c|c|}
\hline Year. & Quantity. & Value. & Year. & Quantity. & Value. \\
\hline & Squares. & & & Squares. & \\
\hline $1890 \ldots \ldots \ldots \ldots \ldots \ldots \ldots \ldots$ & 3,104 & $\$ 18,089$ & $1896 \ldots \ldots \ldots \ldots \ldots \ldots \ldots$ & 4,597 & $\$ 20,388$ \\
\hline $1891 \ldots \ldots \ldots \ldots \ldots \ldots \ldots \ldots$ & 4,000 & 24,000 & $1897 \ldots \ldots \ldots \ldots \ldots \ldots$ & 1,000 & 7,000 \\
\hline $1892 \ldots \ldots \ldots$ & 3,500 & 21,000 & $1898 \ldots \ldots \ldots \ldots \ldots$ & 400 & 2,700 \\
\hline $1893 \ldots \ldots \ldots$ & …...... & .......... & $1899 \ldots \ldots$ & 928 & 6,642 \\
\hline $1894 \ldots \ldots .$. & 900 & 5,850 & $1900 \ldots \ldots$ & 3,500 & 26,500 \\
\hline $1895 \ldots \ldots \ldots \ldots \ldots \ldots$ & 1,500 & 10,500 & $1901 \ldots \ldots \ldots \ldots \ldots \ldots \ldots$ & 2,500 & 18,608 \\
\hline
\end{tabular}

\section{GEORGIA.}

By Edwin G. Eckel.

The workable roofing slate deposits of Georgia occur in the Rockmart (Ordovician) formation, and are developed only near the town of Rockmart, Polk County.

Geology of the slates.-In a recent publication $a$ of this Survey, Dr. C. W. Hayes has described the geologic relations of the Georgia slates as follows:

The Rockmart formation is confined to the Cedartown and Rockmart areas, in the southern portion of the Rome quadrangle. As stated previously, these rocks are contemporaneous with the upper portion of the Chickamauga limestone north of the Coosa Valley. The formation consists chiefly of black slates, originally calcareous shales, but sufficiently altered for the development of slaty cleavage. In addition to the slate, which occupies the lower portion of the formation, it contains beds of highly ferruginous sandstone and some cherty limestone. It also contains coarse conglomerates, made up of limestone pebbles embedded in an earthy matrix. This upper portion of the formation was evidently deposited near the margin of the sea, where the supply of sediment was abundant and variable in character.

The most extensive slate quarries in the United States south of Pennsylvania are located at Rock. mart. The formation in which the quarries are located, the Rockmart slate, extends across the border into the Rome quadrangle, but it is not certain that any workable slate wlll be found in this area. The formation is variable in composition, and to the north of Rockniart consists largely of unaltered clay shales with beds of ferruginous limestone and sandstone,

The portion of the formation which now produces roofing slate was originally a fine-grained homogeneous clay shale. Under the influence of metamorphism, connected probably with the extensive faulting which the region has undergone, a very perfect slaty cleavage was developed, which generally obscures, and in some cases entirely obliterates, the original bedding. East of the quadrangle, along the Cartersville fault, the slate is generally wrinkled near the fault, so that it does not cleave readily, and at a considerable distance from the fault the cleavage is only imperfectly developed. Hence the best slate will be found within a comparatively narrow belt, from 1 to 5 miles from the fault.

$a$ Hayes C. W. Description of the Rome quadrangle: Geologic Atlas U. S., folio 78, U. S. Geol. Survey, 1902 . 
Use of slate in Portland cement manufacture.-Slate is merely a form of shale in which a fine, even, and parallel cleavage has been developed by pressure. In composition, therefore, it will vary exactly as do shales, and, so far as composition alone is concerned, slate would not be worthy of more attention, as a Portland cement material, than any other shale.

Commercial considerations in connection with the slate industry, however, make slate a very important possible source of cement material. Good roofing slate is relatively scarce and commands a good price when found. In the preparation of roofing slate for the market so much material is lost during sawing, splitting, etc., that only about 10 to 25 per cent of the amount quarried is salable as slate. The remaining 75 to 90 per cent is of no service to the slate miner. It is sent to the dump heap, and is a continual source of trouble and expense. This very material, however, as can be seen from the analyses quoted below, is often admirably adapted for use in connection with limestone in a Portland cement mixture. As it is a waste product, it could be obtained very cheaply by the cement manufacturer.

Only one American Portland cement plant is at present using roofing slate as one of its raw materials, and this plant is of recent construction. It is that of the Southern States Portland Cement Company, and is located about half a mile east of Rockmart, Ga. The Portland cement manufactured here is made from a mixture of pure limestone and slate, both of which materials occur in the immediate vicinity of the plant.

East of the town the surface rock is the "Chickamauga limestone," which here contains beds of pure nonmagnesian limestone, which have been quarried at several points in the vicinity and burned into lime.

The cement company purchased the property of the old Georgia Slate Company, about half a mile southwest of Rockmart, and carried on extensive operations with the diamond drill. The intention was to quarry the slate, sell as slate the portions best suited for that use, and utilize the scrap and waste in the manufacture of cement. The quarries from which the limestone is obtained are located half a mile east of town, near the mill.

Analyses of slate used for Portland cement, Rockmart, Ga.

\begin{tabular}{|c|c|c|c|c|c|}
\hline & 1. & 2. & & 1. & 2. \\
\hline Silica $\left(\mathrm{SiO}_{2}\right) \ldots \ldots \ldots \ldots \ldots \ldots \ldots \ldots$ & 57.40 & 58.20 & Alkalis $\left(\mathrm{K}_{2} \mathrm{O}, \mathrm{Na}_{2} \mathrm{O}\right) \ldots$ & $(a)$ & 3.20 \\
\hline Alumina $\left(\mathrm{Al}_{2} \mathrm{O}_{3}\right) \quad \ldots \ldots \ldots \ldots \ldots \ldots$ & 23.65 & 18.83 & Sulphur (S) ........... & $(a)$ & .49 \\
\hline Iron oxide $(\mathrm{FeO}) \ldots \ldots \ldots \ldots . . . . .$. & 4.45 & 5.78 & Carbon $(\mathrm{C}) \ldots \ldots \ldots \ldots$ & (a) & .82 \\
\hline Lime $(\mathrm{CaO}) \ldots \ldots \ldots \ldots \ldots \ldots$ & 3.23 & 4.35 & Carbon dioxide $\left(\mathrm{CO}_{2}\right) \ldots$ & & .60 \\
\hline Magnesia $(\mathrm{MgO})$.................. & 3.23 & 3.51 & Water.................. & 6.80 & 4.07 \\
\hline
\end{tabular}

$a$ Not determined.

1. J. F. Davis, analyst. Privately communicated.

2. Slocum and Vandeventer, analysts, Eighteenth Ann. Rept. U. S. Geol. Survey, pt. 5.

MAINE.

\section{By T. Nelson Dale.}

The slate region of Maine lies about in the center of the State, in the southern part of Piscataquis County, south and southeast of Moosehead Lake and east and west of Sebec Lake, in the towns of Monson, Blanchard, and Brownville. (See map, fig. 4.) Commercial slate occurs also in the town of Forks, Somerset County.

Geological relations. - The slate occurs in a belt consisting largely of slaty rocks, represented by Prof. Charles H. Hitchcock as from 15 to 20 miles wide, and extend- 
ing from the Kennebec River, between Bingham and Dead rivers, northeastward to the sources of the Mattawamkeag River. The rocks are probably of early Paleozoic age. a The portion of this belt now yielding commercial slate lies south of the central granitic area of the State. The general structure of this belt is unknown. At North Blanchard on the west the strike of the bedding is N. $25^{\circ}-39^{\circ}$ E., dip $80^{\circ}$ ESE. Near Blanchard and the Piscataquis River the strike is N. $55^{\circ}-60^{\circ}$ E., and the dip, 40 feet below the surface, is south-southeast at about $80^{\circ}$; but at the top, owing either to the glacier, which moved here S. $20^{\circ}-40^{\circ} \mathrm{E}$., or else to the beginning of an anticline, the dip curves over to the north-northwest. Within $1 \frac{1}{2}$ miles southwest of Monson the strike is N. $60^{\circ} \mathrm{E}$., dip $90^{\circ}$. At Monson the strike is N. $47^{\circ}-54^{\circ} \mathrm{E}$, dip $80^{\circ} \mathrm{SE}$; but at Brownville, 20 miles east of Monson, the strike is N. $78^{\circ} \mathrm{E}$., dip $75^{\circ}$ NNW. As the grain is horizontal at Brownville and at points $3 \frac{1}{2}$ miles west-southwest and $1 \frac{1}{2}$ miles southwest of Monson, a nearly vertical pitch may be assumed for the folds, but it is singular that the jointing in the quartzite beds should not furnish any clue to this pitch.

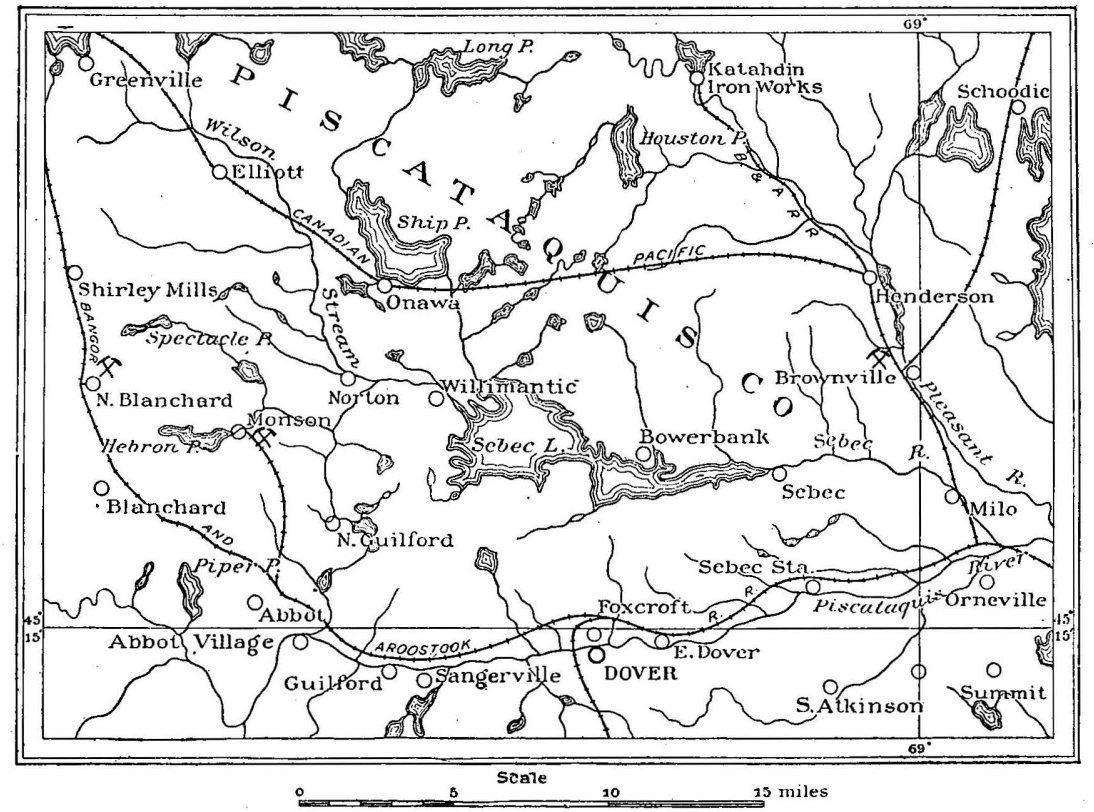

FIG. 4.-Map of slate region in Maine. From Post-route map. The chief quarrying centers are shown by crossed hammers.

Monson.-In 1904 three quarries were in full operation in the town of Monson. The Monson Pond quarry of the Monson Maine Slate Company; the newly opened one of the Maine Slate Company, of Monson, about $3 \frac{1}{2}$ miles west-southwest of the village; and the West Monson quarry, about $1 \frac{1}{2}$ miles southwest of it, operated by the Monson Consolidated Slate Company.

At the Monson Pond quarry the following series is exposed: 15 beds of slate, measuring altogether from 79 feet to 93 feet 6 inches, alternating with 15 beds of dark gray or black quartzite ("hards"), measuring altogether from 48 feet 5 inches to 49 feet 5 inches, both slate and quartzite amounting to from about 127 to about 142 feet. The deposit has been prospected for 200 feet farther southeast, but the

a See Hitchcock, C. H., The geology of northern New England, 1886; also his Preliminary Rept. Nat. Hist. and Geol., Maine, including geological map of northern Maine, pt. 1, 1861, pp. 316, 319, and Second Ann. Rept., 1862, pt. 2, pp. 280, 282, 360. 
slate beds range only from 4 inches to 2 feet in thickness and the quartzite beds vary considerably. The entire thickness explored here thus measures from 327 to 342 feet, and in that thickness there are no indications of duplication. This quartzite is usually very fine grained, and under the microscope proves to be biotitic and pyritiferous, with a little magnetite and muscovite and a few grains of zircon. In order to convey an idea of the great irregularity of the interbedding which marks the entire belt the following measurements of the Pond quarry series at the north edge of quarry are here given:

Section at Monson Pond quarry, Monson, Me.

[Furnished by the courtesy of Mr. F. H. Crane, superintendent.]

Slate

Feet. Inches.

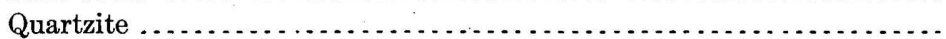
$7-18 \quad 0$

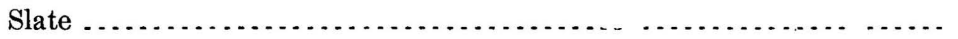

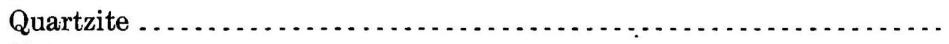

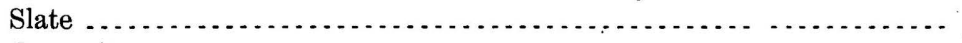

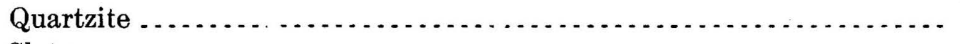

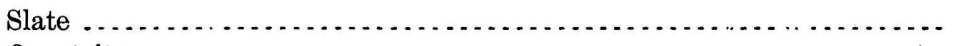

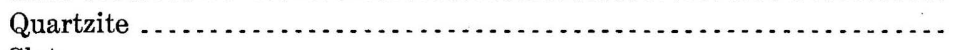

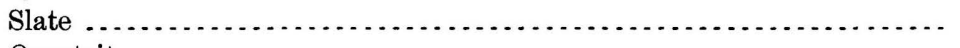

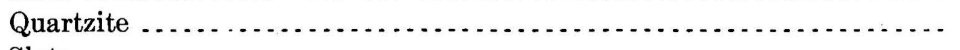

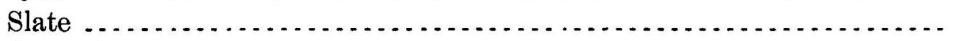

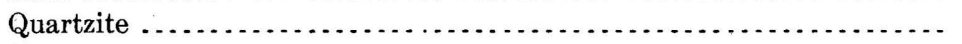

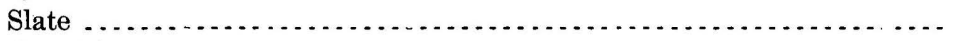

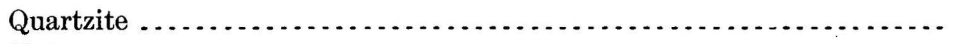

Slate $\ldots \ldots \ldots \ldots \ldots$
Quartzite $\ldots \ldots \ldots \ldots$
(n)

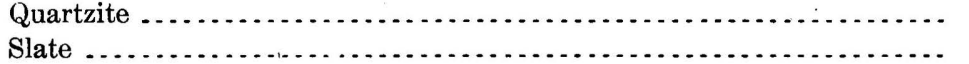

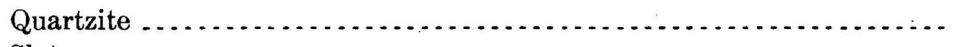

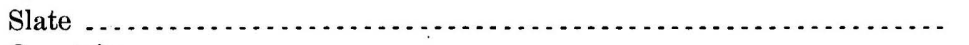

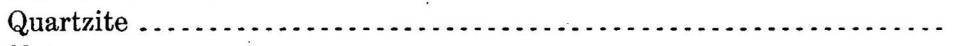

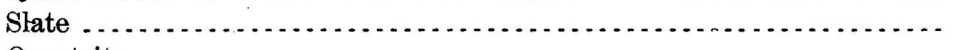

Quartzite ..............

Slate ... . . . . . . . . . . .

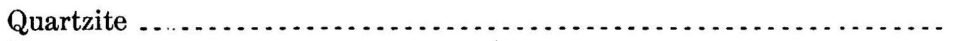

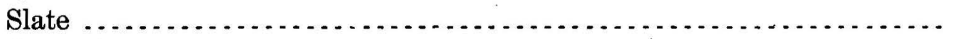

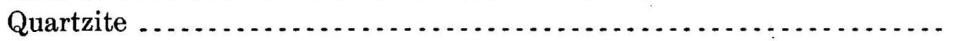

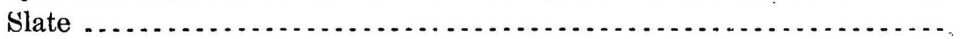

Quartzite ...............

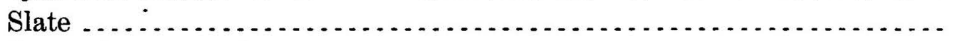

Quartzite :-

$0 \quad 6$

18

Total slate, $79-93$ feet 6 inches.

Total quartzite, 48 feet 5 inches to 49 feet 5 inches.

There is sometimes a transition from the quartzite to the slate, a quartzitic slate intervening. In the above lists such beds are classified as quartzite.

The Pond quarry measures about 500 feet along the strike and nearly 100 feet across it at the top, and from 250 to 300 feet in depth. The beds strike N. $47^{\circ} \mathrm{E}$., $\operatorname{dip} 78^{\circ}-80^{\circ} \mathrm{SE}$., without any indication of turning, and the cleavage strikes $\mathrm{N} .45^{\circ} \mathrm{E}$., dips $90^{\circ}$, thus intersecting the bedding at a very acute angle. The grain strikes N. $45^{\circ}-50^{\circ} \mathrm{W}$. and dips $90^{\circ}$. The slate is traversed at intervals by horizontal joints, which are more frequent in the quartzite-in places from 1 to 4 feet apart. The quartzite also has joints, striking N. $65^{\circ} \mathrm{W}$. and dipping $25^{\circ} \mathrm{N} .65^{\circ} \mathrm{E}$., which often are veined with quartz. There are also vertical diagonal joints striking about north- 
west and thus parallel to the grain. The northeast half of the quarry is much broken up by diagonal jointing and faulting, but in the southwest half conditions are more normal, although veining is there more frequent. The difference between the jointing of the quartzite and the slate results from the difference in their rigidity. Their behavior under the same stress must needs have been very dissimilar. The quartz veins traversing the slate sometimes contain biotite, chlorite, and a little calcite. The surface of the formation is glaciated and covered with from 5 to 10 feet of glacial clay and pebbles.

The slate itself is very dark gray, but at the glaciated surface some of the beds have in bright sunlight a very slightly purplish hue. The fifth bed from the north edge is slightly brownish. To the unaided eye both texture and surface are fine, but the latter is almost lusterless. It is slightly carbonaceous or graphitic, and has very little magnetite. The sawn edge shows a little pyrite. No effervescence in cold dilute hydrochloric acid. It is very sonorous.

Under the microscope this slate shows a matrix of muscovite (sericite) with a brilliant aggregate polarization, but there is considerable irregularity in the size of the particles. Quartz fragments measure "up to 0.017 by $0.008 \mathrm{~mm}$. Occasional quartz lenses measure 0.094 by $0.047 \mathrm{~mm}$. There are to each square millimeter from 30 to 40 scales of chlorite (interleaved with muscovite, rarely with biotite) measuring up to 0.047 by $0.03 \mathrm{~mm}$. and lying transverse to the cleavage; also about ten scales of biotite to each square millimeter measuring up to 0.086 by $0.02 \mathrm{~mm}$., lying both across and with the cleavage, and longish crystals and lenses of pyrite with their long axes parallel to the grain, numbering about fifty to the square millimeter and measuring up to 0.075 by $0.028 \mathrm{~mm}$. These crystals are mostly distorted cubes, but mingled with them are probably some distorted octahedra of magnetite. Scattered throughout is dark-gray carbonaceous or graphitic matter in extremely minute particles, to which and to the biotite the slate owes its blackness. Finally, a few delicate rutile prisms, $0.001 \mathrm{~mm}$. long, some specks of hematite, and a few tourmaline prisms up to 0.036 by $0.004 \mathrm{~mm}$. No carbonate detected.

The constituents of this slate, arranged in the order of their decreasing abundance, appear to be muscovite (sericite), quartz, chlorite, biotite, pyrite, carbonaceous or graphitic matter, magnetite, rutile, and apatite.

The only available chemical analysis of this slate is that by L. M. Norton, $a$ which shows 56.42 per cent of $\mathrm{SiO}_{2}, 24.14$ per cent of $\mathrm{Al}_{2} \mathrm{O}_{3}$, and 0.52 per cent of $\mathrm{CaO}$. This small percentage of lime, taken in connection with the occurrence of a little calcite in the quartz veins, points to the presence of an insignificant amount of carronate, which the microscope fails to detect. But a little of this lime belongs to the apatite. The specific gravity is given by Bailey as 2.851 . Tests of the crushing weight and strength made at the Massachusetts Institute of Technology show that a cubic inch of this slate yields to the pressure of 30,425 pounds when applied at right angles to the cleavage, and that a slab, 12 by 6 by 1 inches, supported on knife edges 10 inches apart, breaks under a stress of from 3,950 to 4,000 pounds applied at the center with a steel rod, five-sixteenths inch in diameter, placed between the slate and the pressure block. This gives a modulus of rupture of 9,937 pounds per square inch.

This slate is split to seven thirty-seconds of an inch for roofing. It is also used for electric purposes, register borders, blackboards, refrigerator shelves, etc.

At the quarry of the Maine Slate Company of Monson, $3 \frac{1}{2}$ miles west-southwest of the village, opened in 1903, there are about 30 feet of slate and interbedded quartzite exposed. The thickest bed of slate measures about 8 feet. In 1904, the quarry measured about 100 feet along the strike, 30 feet across it, and 40 feet in depth. The bedding strikes $\mathrm{N}$. $55^{\circ}-60^{\circ} \mathrm{E}$., and dips about $80^{\circ} \mathrm{SSE}$., but at the surface curves over steeply narth-northwest. The cleavage strikes about the same, but

$a$ See Bailey, W. S., Bull. U. S. Geol. Survey No. 150, 1898, p. 313, and Twentieth Ann. Rept., Pt. VI (Cont.), 1899, p. 394. 
dips $90^{\circ}$. There are vertical dip joints, horizontal joints, and one diagonal one. The grain is parallel to the horizontal jointing, so that the slate has to be sawn in a northwest and southeast vertical direction and split ("sculped") in a horizontal one.

The slate is very dark gray; to the unaided eye has a finer texture and finer cleavage surface than that of the Monson Pond quarry, and also more luster. It is slightly graphitic, has very little magnetite, but the sawn edges show considerable pyrite. It does not effervesce with cold dilute hydrochloric acid, and is very sonorous.

Under the microscope this slate shows a matrix of muscovite (sericite), with a very brilliant aggregate polarization. There are lenses of biotite and quartz, or of quartz with a nucleus of pyrite, measuring up to 0.565 by $0.14 \mathrm{~mm}$., rarely 1 by 0.075 . Quartz fragments, unusually abundant in sections parallel to cleavage, measure up to $0.064 \mathrm{~mm}$; biotite scales, about 18 to each square millimeter, measuring up to 0.13 by $0.028 \mathrm{~mm}$., lie across as well as in the cleavage. Little less abundant than these are scales of chlorite interleaved with muscovite, lying across the cleavage and measuring up to 0.13 by $2 \mathrm{~mm}$. There are also about 300 lenses of pyrite to each square millimeter, with their long axes in the cleavage, and measuring from 0.002 up to $0.094 \mathrm{~mm}$. in length, and up to 0.047 in width and breadth. This number probably includes a few crystals of magnetite. These lenses are sometimes surrounded by secondary muscovite. Generally distributed is a dark grayish or black material, probably graphitic, to which the slate owes its blackness. Tourmaline prisms up to 0.047 by $0.009 \mathrm{~mm}$. No carbonate was detected.

The relative abundance of these minerals appears to be, in descending order, muscovite (sericite), quartz, biotite, chlorite, pyrite, graphite, and magnetite.

The product is at present being prepared exclusively for roofing.

West Monson.-At the quarry of the Monson Consolidated Slate Company a bed of black slate 9 feet thick, with a bed of quartzite 15 feet thick on its north side, and small alternating beds of quartzite and slate on its south side are exposed, the whole series measuring perhaps 50 feet. The quarry in 1904 measured 300 feet along the strike, 15 across it, and 160 in depth. The walls are supported by three pillars of slate. Bedding and cleavage both strike N. $60^{\circ} \mathrm{E}$., and dip $90^{\circ} \mathrm{E}$. There are vertical dip joints striking $\mathrm{N}$. $15^{\circ} \mathrm{W}$; ; also horizontal joints to which the grain is parallel. There are about 15 feet of till on the edges of the glaciated slate. As only one bed of slate is worked, the percentage of waste at this quarry is very small.

The slate is a very dark gray. To the unaided eye texture and cleavage surface are very fine. It has more luster than the Pond quarry slate, but not as much as that of the Maine Slate Company of Monson. It is slightly graphitic, has no magnetite, but shows pyrite on sawn edges; does not effervesce with cold dilute hydrochloric acid, and is very sonorous.

Under the microscope this slate shows a matrix of muscovite (sericite) with a brilliant aggregate polarization. There are a few lenses of quartz and biotite, measuring from 0.107 to 0.13 by $0.034 \mathrm{~mm}$., some lying in the cleavage, others in the direction of the grain. The quartz fragments measure up to 0.02 by 0.012 . There are about nine biotite scales to each square millimeter, measuring up to 0.08 by $0.02 \mathrm{~mm}$.; also about fourteen chlorite scales, measuring 0.047 by $0.02 \mathrm{~mm}$., but sometimes 0.085 by 0.03 , with their longer axes and laminæ usually parallel to the cleavage and across the grain; and finally, twenty to fifty lenses and crystals of pyrite to each square millimeter, measuring, in sections across the cleavage, up to 0.066 by 0.02 , with their longer axes parallel to the cleavage, and the usual finely disseminated carbonaceous matter; also tourmaline prisms up to 0.007 by $0.008 \mathrm{~mm}$. No carbonate was detected.

The probable relative abundance of these constituents, in descending order, is muscovite (sericite), quartz, chlorite, pyrite, biotite, and carbonaceous matter or graphite. Professor Merriman's tests of this slate are given on page 123.

This slate is used both for roofing and mill stock, particularly for electric purposes. 


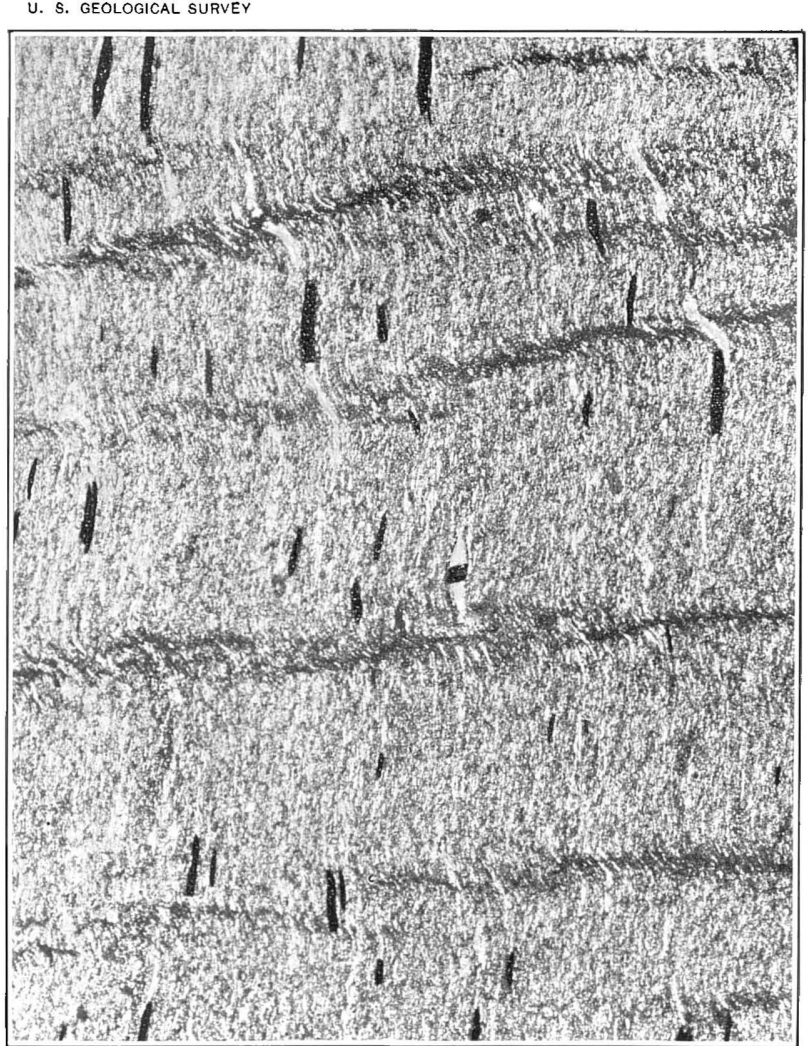

A. THIN SECTION OF BLACK ROOFING SLATE FROM THE

Showing a fine matrix of muscovite (sericite) with distorted octahedra of magnetite and (exceptionally for this quarry) a secondary plication resulting in slip cleavage " false cleavage ". Ordinary light. Enlargement about 50 diameters. Bedding foliation and slaty cleavage here parallel. Lenses of chlorite and muscovite or quartz and muscovite or muscovite about some of the magnetite
crystals.

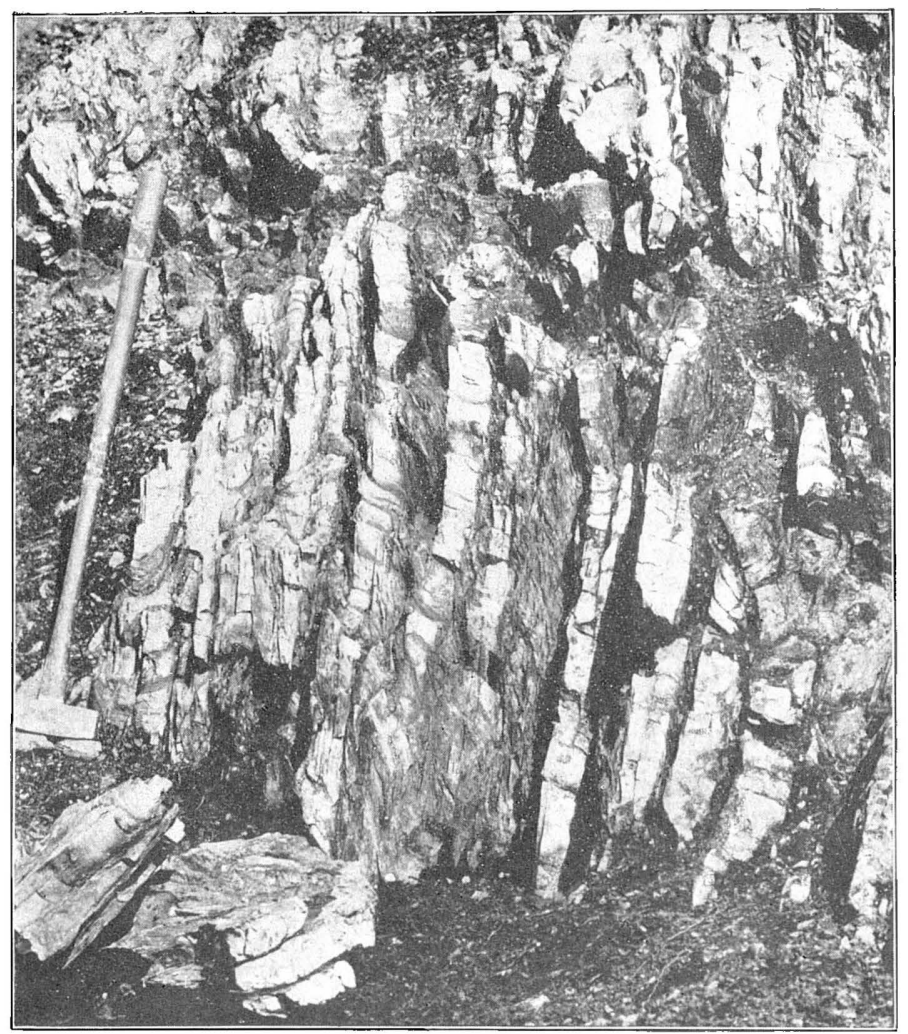

B. Cleavage BANDING.

Shales partly altered to schist in Rupert, Vt., near the Hebron, N. Y., line, showing bands of finely cleft rock alternating with bands of uncleft rock, dipping $80^{\circ}$ across the bedding
foliation, which is visible at several points and dips at a low angle. The cleavage is slip cleavage. Lower block in foreground has three unclett and two cleft bands. Sledge handle is 30 inches long. 

North Blanchard.-There are two quarries at North Blanchard, both operated by the Lowell Slate Company. At the State of Maine or Blanchard quarry 50 feet of slate and quartzite, ten beds of each, in alternation, are exposed, and 200 or 300 feet more have been prospected east of the quarry. The quarry measures between 250 and 300 feet along the strike, 40 to 50 feet across it, and 200 feet in depth. Both bedding and cleavage strike N. $25^{\circ}$ E. and dip east-southeast at $80^{\circ}$. The slate has vertical dip joints striking $\mathrm{N} .70^{\circ} \mathrm{W}$. and diagonal ones striking N. $40^{\circ} \mathrm{W}$., dipping $32^{\circ} \mathrm{SSW}$. There are also joints confined to the quartzite, dipping $65^{\circ}$ to $70^{\circ} \mathrm{SSW}$., and also $65^{\circ}$ to $70^{\circ} \mathrm{NNE}$. The grain strikes N. $65^{\circ} \mathrm{W}$. and dips $90^{\circ}$, almost like the dip joints. The surface of the deposit is glaciated and covered with 10 feet of till. Some of the quartzite surfaces show faint traces of marine life. At the Moosehead quarry, which lies one-half mile southwest or south-southwest of the last, more than 65 feet of slate and quartzite are exposed. The thickest beds of slate measure 4 and 7 feet. The quarry measures about 500 feet along the strike, 50 feet across it, and 125 feet in depth. Bedding and cleavage both strike about N. $37^{\circ}$ E. and dip east-southeast at $80^{\circ}$. Dip joints strike N. $55^{\circ} \mathrm{W}$. and dip $90^{\circ}$. The quartzite on the west side of the quarry is broken up by undulating horizontal joints from 1 to 4 feet apart. The grain corresponds to the dip joints.

The slate from these quarries is a very dark gray. To the unaided eye the texture and cleavage surface are fine, but the latter is only slightly lustrous. The slate contains a little carbonaceous or graphitic matter and no magnetite, but the sawn edges show pyrite. No effervescence in cold dilute hydrochloric acid. It is very sonorous and very fissile.

Under the microscope this slate shows a matrix of muscovite (sericite), with brilliant aggregate polarization. A thin section parallel to the cleavage shows muscovite scales sufficiently numerous and parallel to produce a slight aggregate polarization. This may be due to an unusually pronounced grain. The quartz fragments occasionally measure $0.028 \mathrm{~mm}$., and are not abundant. There are about one hundred scales of chlorite, interleaved with muscovite or sometimes biotite, to each square millimeter, with their laminæ across the cleavage and measuring up to 0.066 by 0.028 ; also, about seven biotite scales to each square millimeter, measuring up to 0.085 by $0.047 \mathrm{~mm}$., often bordered by secondary quartz or muscovite in the direction of the slaty cleavage, but with their laminæ transverse to it. There are about two hundred lenses of pyrite to each square millimeter, measuring from 0.004 to $0.03 \mathrm{~mm}$. in length and up to 0.01 in width; much dark-gray carbonaceous or graphitic matter in exceedingly fine particles; tourmaline prisms up to 0.07 by $0.009 \mathrm{~mm}$. are plentiful. No carbonate or slate needles found. The chief constituents, arranged in descending order of abundance, appear to be muscovite, chlorite, quartz, pyrite, carbonaceous matter or graphite, and biotite.

This slate is used for roofing and mill stock, including electric appliances.

Brownville.-Only one quarry is now in operation at Brownville, the "Old Merrill," operated by the Merrill Brownville Slate Company. This quarry lies less than a mile about northeast of the station (see Pl. XII). Here are exposed 42 beds of slate alternating with as many of quartzite, and measuring altogether 165 feet in thickness. The slate beds range from 6 inches to 6 feet, and the quartzite beds from 6 inches to 5 feet 6 inches. Any quartzitic slate is considered quartzite in these calculations. $a$

At the Hughes quarry, owned by the same company, but now idle, and situated a mile northwest of the Merrill, there are 28 beds of slate alternating with 28 of quartzite, measuring in all 161 feet 6 inches. The slate beds range from 1 to 9 feet and the quartzite from 4 inches to 20 feet in thickness. There is no evidence of duplication in these series of beds. Some of the quartzite is grayish and medium 
grained. Under the microscope it proves to be chloritic, pyritiferous, and slightly biotitic, with rare grains of zircon.

The Merrill quarry measures about 450 feet along the strike; between 165 and 200 feet across it, and 250 in depth. The bedding strikes N. $78^{\circ} \mathrm{E}$., dips $75^{\circ} \mathrm{NNW}$.; the cleavage strikes N. $68^{\circ}$ E., and dips $70^{\circ}$ NNW. Dip joints strike N. $20^{\circ}$ E., dip $82^{\circ}$ WNW.; diagonal joints strike N. $60^{\circ}$ W., dip $90^{\circ}$. There are also horizontal joints, to which the grain is parallel. Quartz veins are not conspicuous, but there. are some quartz lenses from 2 to 3 feet in diameter. These veins contain a little biotite. The south wall of the quarry (see Pl. XII), which is formed by a quartzite bed, is divided into rhombic blocks about 10 feet in their longer diameter, owing to the intersection of joints dipping $25^{\circ} \mathrm{W}$. and $30^{\circ} \mathrm{E}$. respectively. The surface of this bed has also what resembles a coarse ripple marking, but is probably a minor effect of the rhombic jointing.

The slate is a very dark gray. To the unaided eye it has a very fine texture and a very smooth cleavage surface, with a very bright luster. It is slightly carbonaceous or graphitic. When powdered, it yields considerable magnetite to the magnet. The sawn edges show lenses of pyrite a millimeter and less in length. Some of the cleavage and other surfaces on the dumps show a very dark purplish coating. There is no effervescence in cold dilute hydrochloric acid nor any discoloration whatever. It is very sonorois.

Under the microscope it shows a very fine grained matrix of muscovite (sericite), with a very brilliant aggregate polarization. It contains much quartz in fragments up to 0.076 by $0.02 \mathrm{~mm}$.; about 5 biotite plates to each square millimeter, measuring up to 0.076 by $0.03 \mathrm{~mm}$., lying across the slaty cleavage. These often form the nuclei of quartz lenses which measure up to 0.4 by $0.03 \mathrm{~mm}$. But the most conspicuous feature, next to the brilliant matrix, is the abundance of magnetite in tabular crystals, probably distorted octahedra, lying parallel to the cleavage, about 43 to each square millimeter, and measuring from 0.009 to $0.141 \mathrm{~mm}$. in length and up to 0.02 in width; rarely 0.17 by 0.04 . These crystals are sometimes bordered by secondary quartz and muscovite or chlorite, on one or both sides, particularly whenever they happen to diverge from the cleavage direction. These secondary minerals occupy spaces resulting from a movement of the crystals after the commencement of slaty cleavage. There are also, but in less abundance, lenses of pyrite, up to 0.62 long, but sometimes 0.75 and 0.12 wide, and consisting of a nucleus of pyrite surrounded by secondary quartz or by this and biotite, these minerals forming the tapering part of the lens. There is also the usual abundance of dark gray graphitic? material in extremely fine particles. Not a few prisms of tourmaline occur; up to 0.043 by 0.008 $\mathrm{mm}$. No carbonate.

Pl. XI, $A$ will give some idea of the distribution of the magnetite crystals in this slate, but the "false cleavage" of the specimen is not typical of the product of the Merrill quarry-indeed it is quite exceptional. The specimen was selected to illustrate "false cleavage" as well the fineness of slaty cleavage. The principal constituents, arranged in descending order of abundance, appear to be muscovite (sericite), quartz, magnetite, pyrite, carbonaceous matter or graphite, biotite, chlorite, tourmaline. Prof. W. O. Crosby found that the'slate of the East Brownville Slate Company had an average crushing strength of 29.270 pounds to the square inch, the weight being applied perpendicular to the cleavage, and that it required 3,550 pounds to break a slab 6 inches wide, 1 inch thick, and 11 inches long between supports, the load being applied at the middle. This would give a modulus of rupture of 9,762 pounds per square inch. - The results of Professor Merriman's recent tests of Brownville slate will be found on page 123 .

The product of the Merrill quarry is now used exclusively for roofing purposes; its magnetite, it is thought, prevents its use for electric appliances. However, a piece 6 by 4 by one-half inches makes no impression whatever on the magnetic needle, 


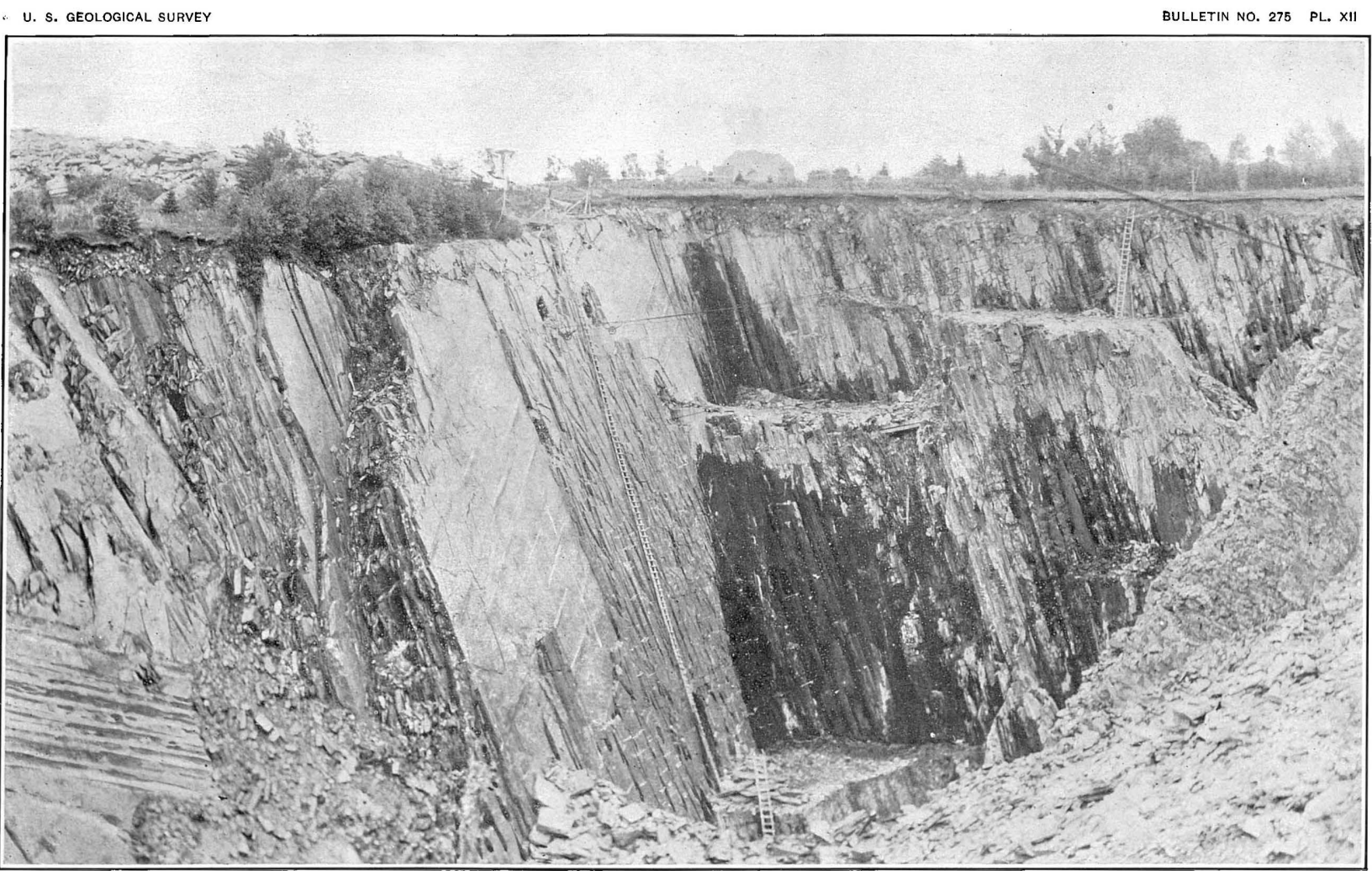

THE MERRILL SLATE QUARRY AT BROWNVILLE, ME.

Seen looking S. $60^{\circ} \mathrm{W}$. The end wall, working face, has 42 beds of slate alternating with as many of quartzite, some of which are visible in the photograph. The left wall consists of a quartzite bed with diagonal jointing. 

and the section photographed in Pl. XI, $A$ came from that piece. The Brownville slate is highly crystalline.

Forks, Somerset County.-A slate prospect opened in this town in 1890 was visited by the writer in 1905. a

This prospect is about 18 miles west of the North Blanchard quarries, in the southwest corner of the town of Forks, about 3 miles northeast of Caratunk, and about a mile north west of Pleasant Pond. It is on Holly Brook, on land owned by Lawrence Hill. The nearest railroad is the Somerset Railway extension at Mosquito Narrows, 6 miles distant.

The cleavage strikes $\mathrm{N} .55^{\circ} \mathrm{E}$. and dips from $90^{\circ}$ to steep northwest and southeast, owing to minor folding. The bedding is probably not far different.

The slate is bluish black, of fine texture and cleavage surface, with a luster not so great as that of the Brownville slate. It is graphitic, contains a very small amount of magnetite, has no argillaceous odor, does not effervesce in cold, dilute hydrochloric acid, is sonorous, splits, and can be perforated readily. Neither the ledge nor the fraginents, said to have been exposed fifteen years, show discoloration.

Under the microscope the section shows a matrix of muscovite (sericite), with a brilliant aggregate polarization, proving it to be a mica slate. The cleavage is fine and regular. There are about 52 lenses of pyrite to each square millimeter, measuring (in transverse section) from 0.02 to $0.06 \mathrm{~mm}$. in length by from 0.004 to 0.016 $\mathrm{mm}$. in width. In sections parallel to the cleavage these lenses have a very irregular outline and are often as broad as long. These lenses account for the limonitic staining on cleavage surfaces of water-soaked specimens. Quartz is abundant but minute. No carbonate was detected. A few tourmaline prisms up to $0.11 \mathrm{~mm}$. in length. Some scales of chlorite with interleaved muscovite measure up to $0.09 \mathrm{~mm}$. There are rare zircon fragments and aggregations of rutile crystals.

The constituents of this slate, arranged in descending order of abundance, appear to be muscovite, quartz, chlorite, pyrite, and graphite, with accessory tourmaline, zircon, and rutile.

This Pleasant Pond slate differs from the Monson slates in having a lustrous and smooth surface, and from the Brownville slate in having much less magnetite and a little less luster. It would prove suitable for roofing or mill stock purposes.

Whether, like the other slates of this State, it is interbedded with quartzite at frequent intervals could not be determined.

The more important features of Maine slates as brought out in the above descriptions will be found set forth in tabular form opposite page 124 .

\section{MARYLAND.}

\section{By T. Nelson Dale.}

The slate of Cardiff, in Harford County, about 30 miles northeast of Baltimore, extends up into Pennsylvania, and will therefore be considered under a heading of its own (see pp. 85-88). Slate occurs also in Montgomery and Frederick counties, about 40 miles west of Baltimore and 33 miles northwest of Washington, where it has been prospected and quarried to a small extent (see map forming fig. 5).

Geological relations.-For the geology of the region the reader is referred to the writings of Williams, Keyes, and Mathews. $b$ Keyes's section passes through Sugarloaf Mountain and along the Baltimore and Ohio (Metropolitan Branch) Railroad to

$a$ See note on a new variety of Maine slate in Bull. U. S. Geol. Survey No. 285.

$b$ Williams, G. H., The petrography and structure of the Piedmont Plateau in Maryland: Bull. Geol. Soc. Am., vol. 2, 1891, pp. 301-318, and map, Pl. XII. Keyes, C. R., A geological section across the Piedmont Plateau in Maryland: Bull. Geol. Soc. Am., vol. 2, 1891, pp. 319, 322, and section fig. 3. Mathews, E. B., On Ijamsville slate: Maryland Geol. Survev vol. 2, 1898, pp. 231-232, and map, Pl. XXX. 
the northern corner of the District of Columbia. It/s important features are these: Sugarloaf Mountain is a mass of eastward-dipping Cambrian sandstone passing toward the east into and under a belt of slaty or schistose rocks (phyllites), which

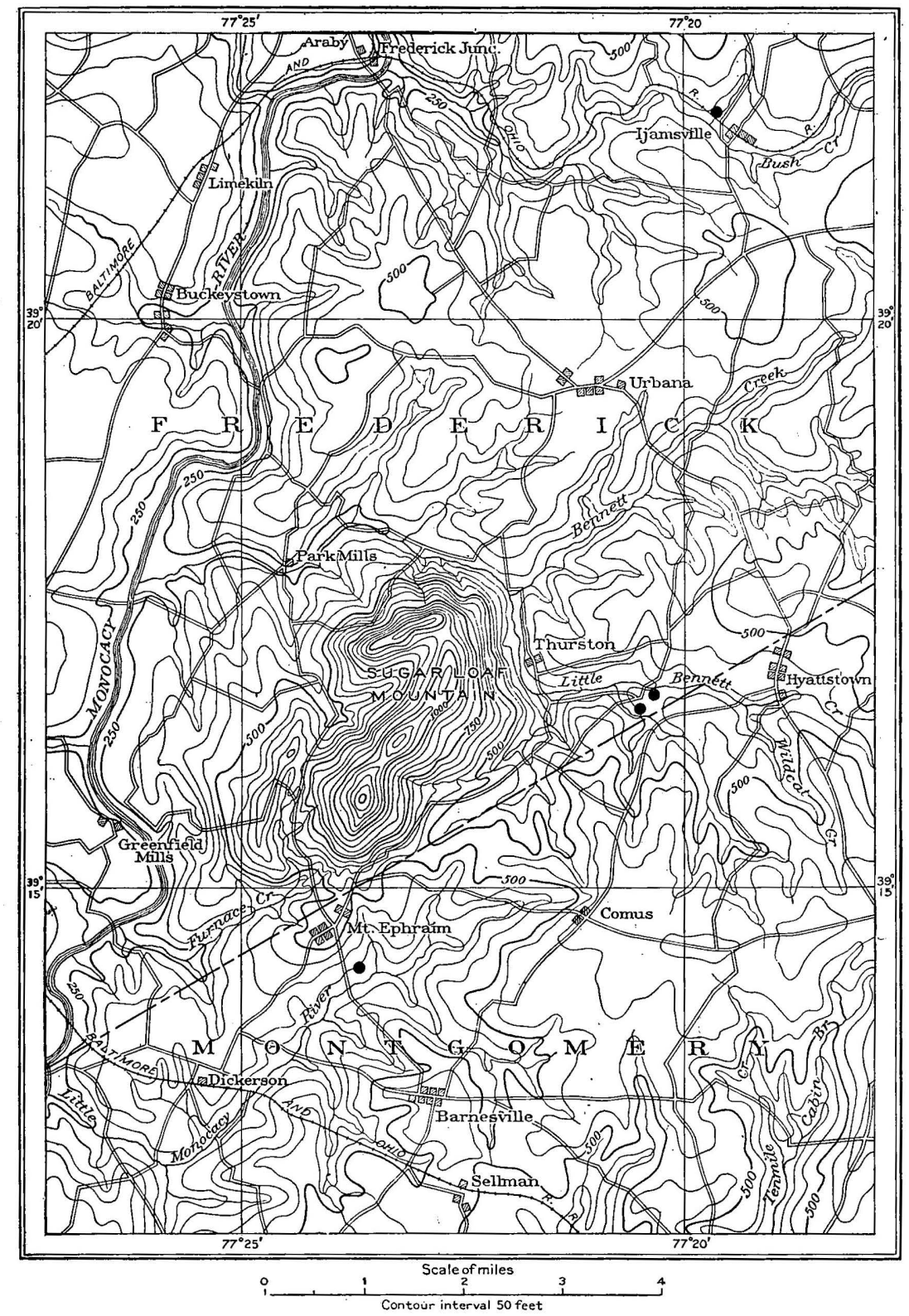

FiG. 5.-Map of parts of Frederick and Montgomery counties, Maryland, showing (by dots) slate prospects and abandoned quarries.

Williams described as containing sericite, chlorite, quartz, hematite, and tourmaline. The phyllite area is traversed in several places by Mesozoic diabase dikes, and east of it are contorted gneisses. 
This slate belt, whatever may be its exact bounds, is well exposed at Ijamsville, on Bush Creek, and the Baltimore and Ohio Railroad in Frederick County, where it has a well-defined strike of N. $10^{\circ} \mathrm{E}$. Between Ijamsville and a point $2 \frac{1}{2}$ miles southsouthwest of that place it is at least $1 \frac{1}{2}$ miles wide, and reappears west of Hyattstown, $3 \frac{1}{2}$ miles farther south in Montgomery County; and from that point its exposures and cleavage strike range from $\mathrm{S} 20^{\circ}$ to $37^{\circ} \mathrm{W}$. It thus passes between Sugarloaf Mountain and the village of Mount Ephraim on the west and Hyattstown and Barnesville on the east, its minimum length and width being about 12 and $1 \frac{1}{2}$ miles respectively. Immediately east of this belt are chloritic schists and altered diabases.

Ijamsville.-One-fourth mile west of Ijamsville station is an abandoned quarry in dark, slightly reddish purple slate. ${ }^{a}$ The bedding, shown by light green ribbons, strikes $\mathrm{N} .10^{\circ}-15^{\circ} \mathrm{E}$, and $\operatorname{dips} 30^{\circ}-40^{\circ} \mathrm{W}$., but the cleavage strikes $\mathrm{N} .40^{\circ} \mathrm{E}$. and dips $50^{\circ} \mathrm{SE}$. There are intermittent joints striking $\mathrm{N}^{\circ} 15^{\circ}-20^{\circ}$ E., dipping $75^{\circ} \mathrm{ESE}$., which have been parted a fourth of an inch, lined with quartz and filled with calcite. Similar slate, but interbedded with light green, occurs also several hundred feet east and north of the station.

Thurston.-On Little Bennett Creek, about a half mile east-southeast of Thurston, in Frederick County, is another quarry (opening 70 by 50 feet) operated twenty years ago but now abandoned. The slate is also dark purplish with light-green passages containing here and there a scaly bright-green mineral, pyrophyllite, which carries from 1 to 2 per cent of copper oxide. The bedding, indicated by coarsely plicated quartzose passages, appears to be about horizontal. A piece of this slate that is said to have been on a roof many years shows some lightening of the color, owing chiefly. to the growth of lichens; but the change is only superficial. The cleavage strikes $\mathrm{N}$. $20^{\circ} \mathrm{E}$. and dips east.ward at an angle of $60^{\circ}$. There is a 2 -foot quartz vein in the "top."

About 600 feet south-southwest of this and one-half mile southeast of Thurston is the quarry recently opened or reopened by the Bennett Creek Slate Company, measuring 75 feet along the cleavage by 65 feet across it, which, in May, 1904. had a depth of 40 feet. The upper 25 feet are "top." The cleavage strikes N. $37^{\circ}$ E. and dips $40^{\circ}$ E., with green spots aligned in the same direction. Joints strike N. $30^{\circ}$ F. and $\operatorname{dip} 40^{\circ} \mathrm{W}$. The grain is almost at right angles to cleavage. The slate is dark purplish but has a bluer tinge than that of Ijamsville. To the unaided eye it has a slightly granular texture, a rather fine cleavage surface with distinet grain and a little luster. It contains no magnetite, does not effervesce with cold dilute hydrochloric acid, and is somewhat greasy to the touch. The sawn elges show light-green particles and more minute pyrite ones. The sonorousness is medium. Some of the slates on exposure develop dark spots, due to the oxidation of some mineral. The amount of quartz is so small that slabs a half inch thick may be easily sawn across the cleavage and the grain with a handsaw.

Under the microscope it shows brilliant aggregate polarization, but much irregularity in size of particles and very slight plications in the direction of the grain. The matrix of muscovite (sericite) contains abundant quart $z$ fragments, measuring up to 0.047 and sometimes $0.094 \mathrm{~mm}$. There are conspicuous scales of chlorite, often interleaved with muscovite lying transverse to the cleavage, measuring up to 0.38 by $0.25 \mathrm{~mm}$., exceptionally $0.66^{\circ}$ by $0.14 \mathrm{~mm}$, and forming the centers of lenses of sericite or talc? ${ }^{b}$ measuring up to $1.5 \mathrm{~mm}$. in length. There are also lenses of sericite or talc? ${ }^{b}$ measuring up to 0.56 by $0.09 \mathrm{~mm}$. with their long axes in the grain direction.

a See Maryland Geol. Survey, vol. 2, pp. 231, 232, pl. XXIV, fig. 2.

$b$ Mathews, following some determination by $\mathrm{G}$. $\mathrm{H}$. Williams, regarded these slates as containing tale. (Maryland Geol. Survey, Vol. 2, p. 232.) A chemical test just made by George Steiger at the U. S. Geol. Survey laboratory shows 0.27 per cent of $\mathrm{SiO}_{2}$, soluble in 1-20 solution of $\mathrm{Na}_{2} \mathrm{SO}_{33}$ before ignition, and 1.09 per cent after ignition. F. W. Clarke, chief chemist, notes that the difference, 0.82 per cent, corresponds to a splitting off of $\mathrm{SiO}_{2.2}$ from the talc if talc is present. It would be one-fourth of the $\mathrm{SiO}_{2}$ in the talc and thus represent a percentage of 5.17 of talc. As the only other silicates in the slate are crystalline quartz, chlorite, muscovite (sericite), and tourmaline, this result is reliable. The combination of chlorite and sericite alone would be sufficient to account for the "talcose" touch of the slate.

Bull. 275-06-6 
These scales and lenses number from 10 to 14 per square millimeter, of which about half are chlorite. Multitudinous minute dots of bright red hematite occur throughout the slate, to which and the chlorite it owes its purplish color. Among these dots are many particles of pyrite, some of which measure up to $0.038 \mathrm{~mm}$. A few of these have passed into limonite. Slate needles $\left(\mathrm{TiO}_{2}\right)$ are somewhat plentiful. No carbonate. Tourmaline 0.076 by $0.009 \mathrm{~mm}$. The important constituents of this slate, arranged in order of abundance, appear to be muscovite, chlorite, quartz, talc, hematite, pyrite.

Its deficient sonorousness is not due to the absence of a micaceous matrix, but to the presence of a large amount of chlorite and to about 5 per cent of talc. It is a mica slate.

Mount Ephraim.-About 4 miles southwest of the Bennett Creek quarries and onefourth mile south-southeast of the village of Mount Ephraim, in Montgomery County, east of road to Barnesville and north of Little Monocacy River, on the property of Abraham Harris, a similar slate has keen prospected. The cleavage strikes $\mathrm{N}$. $30^{\circ}-35^{\circ} \mathrm{E}$. and dips $70^{\circ} \mathrm{E}$. The bedding probably strikes N. $30^{\circ}$ E., dip uncertain.

The characteristics of Maryland slates are shown in the table facing page 124 .

\section{MINNESOTA.}

Location of deposits.-Deposits of roofing slate occur in northern Minnesota, a few miles west of Duluth. At present, however, all the quarries formerly opened here are abandoned, and the quality of the slate, as seen in specimens on the old dumps, is hardly such as to justify reopening.

References on Minnesota slates.-The following reports and papers, while not economic in intention, contain data of interest on the distribution and character of the Minnesota slates:

Hall, C. W. Keewatin area of eastern and central Minnesota. Bulletin Geol. Soc. America, vol. 12, pp. 345-376. 1901.

SpurR, J. E. The stratigraphic position of the Thomson slates. American Journal of Science, 3d series, vol. 48, pp. 159-166. 1894.

Winchell, N. H. The geology of Carlton County: Vol. 4, Final Reports Minnesota Geol. Survey, pp. 1-24. 1899.

- The geology of the southern portion of St. Louis County: Ibid., pp. 212-221. The geology of the Carlton plate: Ibid., pp. 550-565. The geology of the Duluth plate: Ibid., pp. 566-580.

\section{NEW JERSEY.}

The Bangor-Slatington slate belt of Pennsylvania is prolonged eastward into New Jersey, and roofing-slate quarries have been opened at several points, notably near Newton and Lafayette.

\section{NEW YORK. $a$}

By T. Nelson Dale.

\section{GEOLOGICAI REIATIONS.}

The slates of Washington County, N. Y., are a continuation of those of Rutland County, Vt. The Lower Cambrian affords greenish and purplish slates, like those in Vermont described on page 104, which were once extensively quarried at Middle

a The slate of Washington County, N. Y., was described by the writer in part 3 of Nineteenth Ann. Rept. U. S. Geol. Survey in 1899, but the matter appears here in revised form. 
Granville and Jamesville. Overlying the Lower Cambrian, in isolated lenticular synclinal areas or in long, ramifying masses of complex structure, are Ordovician (Hudson) grits and black, red, and green shales; and these red and green shales pass here and there into roofing slates. $a$

While the Lower Cambrian greenish and purplish slates are at present quarried almost exclusively on the Vermont side of the boundary, the red and green slates attain their best development on the New York side, particularly in the towns of Granville, Whitehall, and Hampton. The structural relations of the two slatebearing formations on the New York side are shown in sections I, II, VII of Pl. XXII, and are explained in detail on page 100.

As to mode of occurrence, these red and green slates seem at several points to replace the Hudson grit along the strike. Certainly these slates occur in as close proximity to the Cambrian slates as does the grit. Black graptolite shale sometimes crops out very near to and probably underlies the red slate. Beds of red and green slate alternate vertically, and replace one another along the strike, and also pass into shales of the same colors. The thickness exposed at the quarries reaches 50 and 75 feet, mostly red, with about 25 feet of green overlying, but, subtracting that which is too hard or too soft or badly veined, there are sometimes but 10 feet, rarely more than 25 feet, of good red slate exposed at any one quarry, although it sometimes reaches 42 feet. Owing to the character of the folds and their pitch, as well as the merging of the colors along the strike, it is not easy to ascertain the total thickness of the red and green. A few feet or inches of dark red or purple sometimes occur in the red. Beds of greenish quartzite, sometimes calcareous, and bordered by a purple slate, the whole "ribbon" measuring an inch or two in thickness, are not uncommon (see Pl. II, $A$ ). Also beds one-half inch thick of rhodochrosite (manganese carbonate) with crystalline calcite.

An analysis of this (Specimen D. XIV, '95, 201d), made by Mr. George Steiger, yielded the following:

Analysis of rhodochrosite bed.

\begin{tabular}{|c|c|c|c|}
\hline $\mathrm{Al}_{2} \mathrm{O}_{3} \ldots \ldots \ldots$ & 0.68 & $\mathrm{MgO}$ & 2.61 \\
\hline $\mathrm{Fe}_{2} \mathrm{O}_{3} \ldots \ldots \ldots \ldots$ & .14 & $\mathrm{CO}_{2} \ldots \ldots \ldots \ldots$ & 25.06 \\
\hline $\mathrm{FeO} \ldots \ldots \ldots \ldots$ & 1.13 & Insoluble matter, including all sil- & \\
\hline $\mathrm{MnO} \ldots \ldots$. & 32.22 & ica from dissolved silicates ..... & 32.75 \\
\hline $\begin{array}{l}\mathrm{NiO} \text { and } \mathrm{CoO} \ldots \\
\mathrm{CaO}\end{array}$ & $\begin{array}{r}.10 \\
3.81\end{array}$ & Total & 3.50 \\
\hline
\end{tabular}

Under the microscope thin sections of this bed show, with polarized light, a finegrained bluish-brown matrix identical in color and texture with that of the small lenses in the red slate and with some of the lenses in the green slate; also large areas of calcite and some quartz.

There are also quartz veins in both red and green, sometimes crystallized, and in the red light-green spots with or without a purple rim. Both red and green slates are frequently speckled with lenses (see p. 11). The bedding planes are often covered with glistening annelid trails and with possible impressions of algæ. Thin films of barite and calcite occur on the joint planes.

The location of the more important red slate quarries in the towns of Granville and Hampton are shown on Pl. XX. The structure at two of the quarries is shown diagrammatically in figs. $H$ of Pl. XXIII and $U$ of Pl. XXIV, and the compass courses at the more important quarries, with reference numbers to their location on the map, Pl. XX, are given below, but Nos. $33,39,41$ lie west of the area mapped; 33 is $3 \frac{1}{3}$ miles north-northeast of Middle Granville, in Granville township; 41 is $2 \frac{4}{5}$ miles

$a$ See map forming Pl. XIII in Nineteenth Ann. Rept. U. S. Geol. Survey, pt. 3; also the Economic geology and structure section sheets of the forthcoming Mettawee and Fort Ticonderoga folios. 
northeast of Middle Granville, also in Granville; and 39 is $2 \frac{3}{4}$ miles west of Janesville, in Whitehall.

\begin{tabular}{|c|c|c|c|c|c|c|c|}
\hline \multirow{2}{*}{ Quarry number. } & \multicolumn{2}{|c|}{ Bedding. } & \multicolumn{3}{|c|}{ Cleavage. } & \multicolumn{2}{|c|}{ Strike joints. } \\
\hline & Strike. & Dip. & \multicolumn{2}{|c|}{ strike. } & Dip. & Strike. & Dip. \\
\hline $33 \ldots$ & & \multirow{2}{*}{$\begin{array}{l}30 \pm \mathrm{E} \\
45^{\circ} \mathrm{E}\end{array}$} & \multicolumn{2}{|c|}{........... } & $\ldots \ldots \ldots$ & & \\
\hline $34 .$. & & & \multicolumn{2}{|c|}{ (n............ } & \multirow{2}{*}{$20^{\circ} \mathrm{E}$} & & \\
\hline 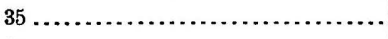 & N.+ & \multirow{2}{*}{$\begin{array}{l}15^{\circ} \mathrm{E} . \\
\text { E.-W. }\end{array}$} & \multirow{2}{*}{\multicolumn{2}{|c|}{$\begin{array}{l}\text { N. } 15^{\circ} \mathrm{E} . \\
\text { N. } 5^{\circ} \mathrm{E} .\end{array}$}} & & ........ & \\
\hline $36 \ldots$ & N. $20^{\circ} \mathrm{W}$. & & & & $30^{\circ} \mathrm{E}$. & N.+ & $55^{\circ} \mathrm{E}$. \\
\hline & N. $12^{\circ} \mathrm{W}$. & \multirow{2}{*}{$\begin{array}{l}35^{\circ} \mathrm{E}, \\
25^{\circ} \mathrm{E} .\end{array}$} & \multirow{2}{*}{\multicolumn{2}{|c|}{$\begin{array}{l}\text { N. } 12^{\circ} \mathrm{W} . \\
\text { N. } 5^{\circ} \mathrm{W} .\end{array}$}} & $35^{\circ} \mathrm{E}$. & (n............. & .......... \\
\hline 38 . & N. $10^{\circ} \mathrm{W}:$ & & & & \multirow{2}{*}{$\begin{array}{l}30^{\circ} \mathrm{E} . \\
45^{\circ} \mathrm{E} .\end{array}$} & N. $10^{\circ} \mathrm{W}$. & $25^{\circ} \mathrm{E}$ \\
\hline 39 . & N. $5^{\circ} \mathrm{E}$. & $50^{\circ} \mathrm{E}$. & \multirow{2}{*}{\multicolumn{2}{|c|}{$\begin{array}{l}\text { N. } 5^{\circ} \mathrm{W} . \\
\mathrm{N} .\end{array}$}} & & & \\
\hline $40 \ldots \ldots \ldots$ & & \multirow{2}{*}{$\begin{array}{l}35^{\circ} \mathrm{E} . \\
30^{\circ} \mathrm{E} .\end{array}$} & & & \multirow{3}{*}{$\begin{array}{l}40^{\circ} \mathrm{E} \\
40^{\circ} \mathrm{E} \\
25^{\circ} \mathrm{E}\end{array}$} & \multirow{2}{*}{ N. $15^{\circ} \mathrm{W}$. } & ............ \\
\hline $41 \ldots \ldots \ldots$. & & & \multirow{2}{*}{\multicolumn{2}{|c|}{$\begin{array}{l}\text { N. } \\
\text { N. }\end{array}$}} & & & $50^{\circ} \mathrm{E}$ \\
\hline $64 \ldots \ldots \ldots \ldots \ldots \ldots \ldots \ldots$ & N. $15^{\circ} \mathrm{W}$. & \multirow{2}{*}{$\begin{array}{l}22^{\circ} \mathrm{E} . \\
20^{\circ} \mathrm{E} .\end{array}$} & & & & & \\
\hline $66 \ldots \ldots \ldots \ldots \ldots \ldots$ & N. $30^{\circ} \mathrm{W}$. & & \multicolumn{2}{|c|}{ N. $15^{\circ} \mathrm{W}$. } & $25^{\circ} \mathrm{E}$ & & \\
\hline \multirow{2}{*}{ Quarry number. } & \multicolumn{2}{|c|}{ Dip joints. } & \multicolumn{2}{|c|}{ Diagonal joints. } & \multirow{2}{*}{$\begin{array}{l}\text { Grain } \\
\text { strike. }\end{array}$} & \multicolumn{2}{|c|}{$\begin{array}{l}\text { Shear zones.; } \\
\text { "Hogbacks." }\end{array}$} \\
\hline & Strike. & Dip. & Strike. & Dip. & & Strike. & Dip. \\
\hline $33 .$. & & & N. $30^{\circ} \mathrm{E}$. & $70^{\circ} \mathrm{W}$ & & & \\
\hline $34 \ldots$ & N. $65^{\circ} \mathrm{W}$. & $90^{\circ}$ & & & & & -3 \\
\hline 35. & . & $\cdots \cdot$ & & & & & \\
\hline 36. & E.-W. & $90^{\circ}$ & & & & & \\
\hline $37 \ldots$ & (n............ & ....... & & & & & \\
\hline $38 \ldots$ & N. $75^{\circ} \mathrm{W}$. & $90^{\circ}$ & $\ldots$ & & & & \\
\hline $39 \ldots$. & . & . & & & & & \\
\hline $40 \ldots \ldots \ldots \ldots \ldots$ & .............. & ....... & & & & N. $7^{\circ} \mathrm{E}$. & $77^{\circ} \mathrm{E}$. \\
\hline $41 \ldots \ldots$. & N. $77^{\circ} \mathrm{E}$. & $90^{\circ}$ & & & & & \\
\hline $64 \ldots \ldots \ldots \ldots \ldots \ldots \ldots$ & & & & & & & \\
\hline 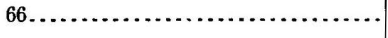 & N. $80^{\circ} \mathrm{W}$. & $90^{\circ}$ & & & & N. $55^{\circ}$ W. & $70^{\circ} \mathrm{NE}$. \\
\hline
\end{tabular}

DESCRIPTIONS OF THE SLATES.

Red slate.-The "red" slate is a decidedly reddish brown, becoming brighter on exposure. To the unaided eye its texture is fine, and its cleavage surface varies from slightly roughish to speckled with minute protuberances ("eyes" or "knots"), in either case without luster. It is magnetitic, sometimes effervesces with cold dilute $\mathrm{HCl}$, is sonorous, and has an argillaceous odor. Under the microscope shows a matrix of muscovite (sericite) with somewhat faint aggregate polarization, but this faintness is partly due to obscuration by carbonate and hematite, many of the plates of the former remaining light when all the mica is dark and the hematite darkening the mica when it is light. Distributed throughout the matrix are multitudinous bright-red hematite dots of circular or irregular oval outline, measuring from 0.0004 to $0.009 \mathrm{~mm}$. There is much irregularity in the size of the particles, indicating but a fair grade of fissility. The larger particles consist of quartz fragments up to 0.06 by 0.03 , rare grains of plagioclase feldspar and of zircon, considerable carbonate in rhombs or plates up to $0.047 \mathrm{~mm}$.; scales of chlorite interleaved with muscovite, up to 0.075 by 0.036 mm., a very variable number of lenses up to 0.34 by 0.15 , rarely $0.5 \mathrm{~mm}$. long, consisting probably of rhodochrosite (carb. manganese) and chalcedonic quartz (containing carbonate rhombs and muscovite scales, sometimes partial pseudomorphs of chlorite after carbonate), and finally some tourmaline prisms up to 0.005 by $0.001 \mathrm{~mm}$.

The chief constituents of the red slate, arranged in descending order of abundance, appear to be muscovite (sericite), quartz, hematite, kaolin, carbonate, chlorite, magnetite, rhodochrosite. For colored lithographs of magnified thin sections of this 
slate, as seen under both ordinary and polarized light, see Nineteenth Annual Report U. S. Geological Survey, part 3, Pl. XXVIII, $A, B, C$. For a discussion of the causes of the green and purplish spots, which occasionally occur in this slate, see page 15 of this bulletin. Associated with the red slate is generally a little purplish slate, sometimes speckled, but of no commercial importance. Under the microscope it shows less hematite and possibly more chlorite. Analysis N, below, shows that it contains from $2 \frac{1}{2}$ to over 4 per cent less hematite and about one-third of 1 per cent more ferrous oxide than the red.

The following analyses were made in the chemical laboratory of the United States Geological Survey, the complete analyses by Dr. W. F. Hillebrand, the partial ones by Mr. George Steiger:

Analyses of red slates from New York.

\begin{tabular}{|c|c|c|c|c|c|c|}
\hline \multirow{2}{*}{ 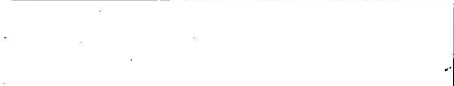 } & \multicolumn{6}{|c|}{ Specimens. $a$} \\
\hline & J. & $\mathrm{K}$. & L. & M. & K. ${ }^{2}$ & N. \\
\hline $\mathrm{SiO}_{2}($ silica $) \ldots \ldots \ldots \ldots \ldots$ & 67.61 & 67.55 & 56.49 & 63.88 & & \\
\hline $\mathrm{TiO}_{2}$ (titanium dioxide) $\ldots \ldots \ldots \ldots \ldots$ & .56 & .58 & .48 & .47 & & \\
\hline $\mathrm{Al}_{2} \mathrm{O}_{3}$ (alumina) $\ldots \ldots \ldots \ldots \ldots \ldots \ldots \ldots \ldots \ldots$ & 13. 20 & 12.59 & 11.59 & 9.77 & & \\
\hline $\mathrm{Fe}_{2} \mathrm{O}_{3}$ (ferric oxide) $\ldots \ldots \ldots \ldots \ldots$ & 5.36 & 5.61 & 3.48 & 3.86 & 7.10 & 1.02 \\
\hline FeO (ferrous oxide) ...................... & 1,20 & 1.24 & 1.42 & 1.44 & 1.00 & 1. 67 \\
\hline MnO (manganous oxide)... & .10 & .19 & .30 & .21 & & \\
\hline NiO (nickelous oxide) ................. & Trace? & Trace. & Trace. & Trace. & & \\
\hline $\mathrm{CoO}($ cobaltous oxide $) .. . \ldots \ldots \ldots \ldots$ & Trace? & Trace. & Trace. & Trace. & & \\
\hline $\mathrm{CaO}$ (lime) .................. & .11 & .26 & 5.11 & 3.53 & & \\
\hline 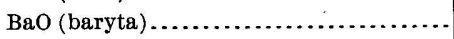 & .04 & .31 & .06 & .05 & & \\
\hline 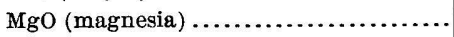 & 3.20 & 3.27 & 6.43 & 5.37 & & \\
\hline 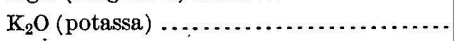 & 4.45 & 4.13 & 3.77 & 3.45 & & \\
\hline $\mathrm{Na}_{2} \mathrm{O}$ (soda) $\ldots \ldots \ldots \ldots \ldots$ & .67 & .61 & .52 & .20 & & \\
\hline $\mathrm{Li}_{2} \mathrm{O}$ (lithia) $\ldots \ldots \ldots \ldots \ldots \ldots \ldots \ldots \ldots \ldots \ldots \ldots \ldots \ldots \ldots \ldots$ & Trace. & Trace. & Str. tr. & Str. tr. & & \\
\hline $\mathrm{H}_{2} \mathrm{O}$ (water below $\left.110^{\circ} \mathrm{C}\right) \ldots \ldots \ldots \ldots$ & .45 & .40 & .37 & .27 & & \\
\hline $\mathrm{H}_{2} \mathrm{O}$ (water above $\left.110^{\circ} \mathrm{C}\right) \ldots \ldots \ldots \ldots \ldots$ & 2.97 & 3.03 & 2.82 & 2.48 & & \\
\hline $\mathrm{P}_{2} \mathrm{O}_{5}$ (phosphoric oxide) $\ldots \ldots \ldots \ldots \ldots \ldots$ & .05 & .10 & .09 & .08 & & \\
\hline $\mathrm{CO}_{2}$ (carbon dioxide) $\ldots \ldots \ldots \ldots \ldots \ldots \ldots$ & None. & .11 & 7.42 & 5.08 & & \\
\hline $\mathrm{FeS}_{2}$ (pyrite) $\ldots \ldots \ldots \ldots \ldots \ldots \ldots \ldots$ & .03 & .04 & .03 & Trace. & & \\
\hline $\mathrm{SO}_{3}$ (sulphuric oxide) $\ldots \ldots \ldots \ldots \ldots \ldots \ldots$ & Trace. & Trace. & Trace. & & & \\
\hline $\mathrm{C}$ (carbon) & None. & None. & None. & None. & & \\
\hline Total........ & 100.00 & 100.02 & 100. 38 & 100.14 & & \\
\hline S (total sulphur) $\ldots \ldots \ldots \ldots \ldots \ldots \ldots \ldots$ & .016 & .02 & .016 & & & \\
\hline Specific gravity $\ldots \ldots \ldots \ldots \ldots \ldots \ldots \ldots \ldots \ldots$ & & & 2. 7839 & & 2.8085 & \\
\hline
\end{tabular}

a J (=D. XIV, '95, 358d), red slate, H. H. Matthews's quarry, 1 mile west of Poultney, in Hampton, Washington County, New York; J ( =D. XIV, '95, 201e), red slate, Empire Red Slate Company's quarry, 1 mile north of Granville, in Granville, Washington County, N. Y.: L $(=\mathrm{D}$. XIV, '95, 397e), red slate, National Red Slate Company's quarry, 1 mile north-northwest of Raceville, in 'Granville; Washington County, N. Y.; M (=D. XIV, ' $95,397 a)$, red slate, same locality as L, bit near a green and Washington County, $\mathrm{N}$. Y.; $M(=\mathrm{D}$. XIV, $95,397 a)$, red slate, same locality as $L$, but near a green and
purple spot; $\mathrm{K}^{2}(=\mathrm{D}$. XIV, ' $95,201 \mathrm{~h})$, red slate, same as $\mathrm{K}$, but finer grained; $\mathrm{N}(=\mathrm{D}$. XIV,' $95,284 a)$, purple bed in red slate at Fair Haven Red Slate Company's quarry (not worked), two miles north of Truthville, in East Whitehall, Washington County, N. Y. For presence of chromium and vanadium in these see Doctor Hillebrand's note, p. 41.

Some points in these analyses are discussed by Doctor Hillebrand on pages 39-42.

As these red slates do not discolor and yet show a considerable amount of carbonate under the microscope, and as the discoloration of the Vermont "sea-green" slates is due to the oxidation of a ferrous carbonate, it may be inferred that the carbonate here is chiefly one of lime and magnesia, but the effect of a very small percentage of ferrous carbonate would probably be masked by the brightness of the hematite.

J. F. Williams reported for this slate a modulus of rupture of 7,310 pounds per square inch, and Merriman 126.66 foot-pounds of work per pound of slate as a result of impact tests. Thə results of Merriman's recent other tests of this slate are given on page 123. 


\section{SLATE DEPOSITS AND INDUSTRY OF. UNITED STATES.}

Bright-greenish slate.-The reddish slate is usually interbedded and exceptionally passes along the strike into a light bluish-green slate, brighter in color than the "unfading green" Cambrian slates of Vermont. Its color is peculiarly bright by lamplight; its texture and surface are similar to those of the "red," and the surface is also sometimes speckled with minute lenses. It is magnetitic, effervesces very slightly with cold dilute hydrochloric acid, is sonorous and is said to be unfading.

Under the microscope shows a matrix of muscovite (sericite) with a more brilliant aggregate polarization than that of the red slates, which may be due to the absence of the hematite, but the coarseness of the particles does not indicate a superior fissility. There are quartz grains up to 0.084 by $0.056 \mathrm{~mm}$., chlorite scales up to 0.043 $\mathrm{mm}$., some carbonate rhombs from 0.002 to $0.056 \mathrm{~mm}$., and lenses measuring up to 0.385 by $0.128 \mathrm{~mm}$., that consist either of rhodoch rosite or chalcedonic quartz inclosing very minute carbonate rhombs and chlorite scales. Sections parallel to the cleavage show these lenses with a more roundish outline. There are also particles of pyrite, tourmaline prisms, rutile needles, and grains of zircon.

The chief constituents of this slate, arranged in descending order of abundance, appear to be muscovite (sericite), quartz, chlorite, carbrnate, magnetite, rutile.

Its color is due to the abundance of chlorite.

Bright-greenish roofing slate.-The following analysis (specimen $\mathrm{O}=\mathrm{D}$. XIV, '95, 397c), by Dr. W. F. Hillebrand, is of a bright-greenish speckled slate from the National Red Slate Company's quarry, 1 mile north of Raceville, in Granville, Washington County, N. Y.

\section{Analysis of bright-greenish slate from New York.}

\begin{tabular}{|c|c|c|c|}
\hline $\mathrm{SiO}_{2}$ (silica) $\ldots$ & 67.89 & $\mathrm{Na}_{2} \mathrm{O}$ (soda) ..... & .77 \\
\hline $\mathrm{TiO}_{2}$ (titanium dioxide $) \ldots$ & .49 & $\mathrm{Li}_{2} \mathrm{O}$ (lithia).... & Trace. \\
\hline $\mathrm{Al}_{2} \mathrm{O}_{3}$ (alumina) $\ldots \ldots \ldots \ldots \ldots \ldots$ & 11.03 & $\mathrm{H}_{2} \mathrm{O}$ (water below $110^{\circ} \mathrm{C}$.). & .36 \\
\hline $\mathrm{Fe}_{2} \mathrm{O}_{3}$ (ferric oxide) $\ldots . . . \ldots \ldots . .$. & 1.47 & $\mathrm{H}_{2}^{\circ} \mathrm{O}$ (water above $110^{\circ} \mathrm{C}$.). & 3. 21 \\
\hline $\mathrm{FeO}$ (ferrous oxide) ........ & 3.81 & $\mathrm{P}_{2} \mathrm{O}_{5}$ (phosphoric oxide) ... & .10 \\
\hline $\mathrm{MnO}$ (manganous oxide) & .16 & $\mathrm{CO}_{2}$ (carbon dioxide) $\ldots$ & 1.89 \\
\hline $\mathrm{NiO}$ (nickelous oxide) ... & Trace? & $\mathrm{FeS}_{2}$ (pyrite) ............ & .04 \\
\hline $\mathrm{CoO}$ (cobaltous oxide) & Trace? & $\mathrm{SO}_{3}$ (sulphuric oxide) ... & Trace. \\
\hline $\mathrm{CaO}$ (lime) . . . . . . . . . & 1.43 & $\mathrm{C}$ (carbon) $\ldots . . . . .$. & None. \\
\hline $\mathrm{BaO}$ (baryta) ....... & .04 & & \\
\hline $\mathrm{MgO}$ (magnesia) .... & 4.57 & & \\
\hline $\mathrm{K}_{2} \mathrm{O}$ (potassa) ........... & 2.82 & S (sulphur, total). & \\
\hline
\end{tabular}

Specific gravity $=2.7171$.

The relatively high percentage of magnesia is attributed to the abundance of both dolomite and chlorite.

The results of Professor Merriman's recent tests of the bright-greenish slates quarried by the Mathews Consolidated Slate Company are given on page 123.

Black slate.-Black roofing slate of Ordovician age was quarried many years ago, in a small way, 3 miles south of Hoosick Falls, near Hoosick, and also, at a later time, 2 miles south of Stephentown, near Lebanon Springs, in Rensselaer County, N. Y., but did not prove to be of economic importance at either locality. $a$

The principal features of New York slates as brought out in the above descriptions will be found in tabular form opposite page 124 .

$a$ Pl. CI and fig. 26, Thirteenth Ann. Rept. U. S. Geol. Survey, show the structure at the Lebanon Springs quarry. 


\title{
PENNSYLVANIA.
}

\author{
By T. Nelson Dale.
}

\section{GENERAL FEATURES.}

The slates of Pennsylvania, aside from those of Lancaster County and the southeastern part of York County, which are described under the heading "Peach Bottom". slate (pp. 85-88), occur in Northampton and Lehigh counties in a strip from 2 to 4 miles wide on the southern side of the Blue Mountain, extending from Delaware Water Gap in a west-southwest direction to a point 4 miles west of Lehigh Gap, a distance of about 32 miles. The chief centers of the slate industry here are at Bangor and Slatington. The geographical relations of these places and of the other groups of slate quarries in these counties are shown on the maps of the Second Pennsylvania Geological Survey of Merrill's Stones for Building and Decoration (third edition) and of Merriman's article in Stone for July, 1898.

The general geological relations of this slate are these: On the southeast, forming an east-northeast to west-southwest belt between Easton and Reading and beyond, are the pre-Cambrian gneisses, etc., of South Mountain, flanked and dotted over with strips of Lower Cambrian quartzite and sandstone. Northwest of this and parallel to it is a great Cambro-Ordovician dolomite and limestone plain from 3 to 6 miles wide, under which the quartzite dips. Still farther north west is a slightly hilly belt of Ordovician shales, grits, and roofing slates of Hudson age, from 6 to 8 miles wide. At the southeast these shales and slates overlie the limestone, and at the northwest they dip under the Silurian conglomerate and sandstone of the Blue Mountain. The boundary between the shale and slate formation and the limestone is roughly parallel to the general course of the Oneida and Medina boundary, but passes a little north of Nazareth.

The shale and slate formation measures from a minimum exposure of 1,600 feet to an estimated maximum of 6,000 feet, of which the commercial slate comprises but a few hundred feet. In structure this formation consists of a succession of minor close folds, generally overturned to the northern horizon, so that their axial planes have a southerly dip but usually so that the syńclines have a steeply inclined southern and a gently inclined northern limb. Sometimes the fold is extremely close and the overturn so complete that its axial plane has a very low southeasterly dip. The cleavage dips to the southern horizon at various angles, sometimes at one of $5^{\circ}$, pointing, like the curvature of cleavage and jointing, to a secondary movement. These folds vary greatly in width and their axes also pitch alternately east-southeast and west-northwest at angles ranging from $5^{\circ}$ to $10^{\circ}$. They also bend laterally from north to south. These folds have been more or less truncated by surface erosion, and in places the cleavage foliation has heen crushed and bent over to the south by the friction of the southward-moving ice sheet.

"Ribbons," or small beds of grit, measuring from a fraction of an inch to two feet in thickness, characterize the slate belt throughout. This grit consists mostly of more or less angular grains of quartz and feldspar, rarely of shale and quartzite, together with scales of muscovite and lenses of chlorite, spherules of pyrite, carbonaceous matter, all in a cement of calcite and sericite with rhombs of carbonate more or less altered to limonite. The ribbons, as explained on page 6, represent coarse sediments, brought in, probably, by local marine currents.

Commercial slate is obtained along two belts. The upper and northerly one, known as the "soft vein," which is separated from the overlying Silurian conglomerate by an uncertain thickness of shale and slate, consists of beds of relatively soft slate of sufficient thickness between the ribbons to furnish large. slabs suitable for mill stock or roofing purposes. The lower and southerly belt, the " hard vein," near the base 
of the Hudson formation, consists of small beds of harder slate separated by small ribbons which are not coarse enough to interfere with their use either as mill stock or roofing slate.

The Bangor, East Bangor, Pen Argyl, Danielsville, Slatington, and Slatedale quarries are in the "soft vein" belt and the Belfast and Chapman are in the "hard vein." Judging from the map of the Second Geological Survey, Pennsylvania, which represents a limestone area, presumably anticlinal in structure, as extending from the Delaware near Portland to the vicinity of East Bangor, the "hard vein" ought to recur there near the limestone.

The literature of the slate of Northampton and Lehigh counties will be found in the Bibliography on pages 138-145, under the names Chance, Lesley, Merrill, Merriman, Rogers (H. D.), Sanders.

A few typical quarries and slates from these belts will now be described.

\section{NORTHAMPTON COUNTY.}

Bangor. - The "Old Bangor" quarry at Bangor, now operated by J. S. Moyer \& Co., is the largest slate quarry in the United States and the oldest one in this region. It is regarded as being near the top of the "soft vein" belt. It measures over 1,000 feet along the strike, 500 across it, and from 200 to 300 feet in depth. (See Pls. XIII-XV.) The general structure is a close overturned syncline, striking about N. $25^{\circ}$ E., with an axial plane dipping east-southeast at a low angle and pitching $5^{\circ}-10^{\circ} \mathrm{SSW}$., crossed by cleavage dipping from $5^{\circ}$ to $10^{\circ} \mathrm{S} .32^{\circ} \mathrm{E}$. There is a gritty bed both at the top and bottom of the quarry, which is regarded as the limit of the slate-i. e., the lower limit, drill cores from a depth of 200 feet below the quarry having failed to show any good slate. The thickest bed of good slate is 9 feet thick. Vertical diagonal joints striking N. $52^{\circ}-57^{\circ}$ E. are conspicuous. There are also vertical dip joints and horizontal ones. Curvature of the cleavage occurs here and there. Certain diagonal or longitudinal joints intersecting the bedding planes at the northern corner of the quarry produce an optical illusion, for the beds there seem to curve over to the west-northwest instead of the east-southeast, and thus, in connection with the syncline on the east-southeast wall, to form a complete ellipsoid. The ribbons are markedly more calcareous than the slate, and in weathering become white from incrustation of lime. Veins of white calcite and quartz, 4 inches thick, occur in the strike joints. Crystalline films of gypsum were collected on the horizontal joint faces.

The slate from the "Old Bangor" quarry is very dark gray, and to the unaided eye has a fine texture and a fine cleavage surface, almost without any luster. The sawn edge shows pyrite. It contains very little magnetite, is carbonaceous or graphitic; effervesces with cold dilute hydrochloric acid, is sonorous, and has an argillaceous odor.

Under the microscope this slate shows a matrix of muscovite (sericite), with a brilliant aggregate polarization, somewhat obscured by abundant carbonate in plates and rhombs. The cleavage is regular, but the particles are coarse. There are occasional chlorite scales up to 0.124 by $0.066 \mathrm{~mm}$.; quartz grains not very abundant up to $0.047 \mathrm{~mm}$. Pyrite spherules number about two hundred per square millimeter, measuring up to $1.01 \mathrm{~mm}$. in diameter. Rutile needles are very pléntiful. Carbonaceous or graphitic matter occurs in fine particles throughout.

A tranverse section of a coarse ribbon from this quarry showed, under the microscope, bedding crossed by cleavage at an angle of $27^{\circ}$, a matrix of sericite in irregular stringers, without any aggregate polarization, and carbonate and carbonaceous matter, coutaining angular quartz grains up to 0.17 by $0.12 \mathrm{~mm}$., feldspar grains (plagioclase, orthoclase) up to 0.14 by $0.09 \mathrm{~mm}$., the quartz and feldspar together making up no more than 25 per cent of the ribbon; also spherules of pyrite up to $0.07 \mathrm{~mm}$., 


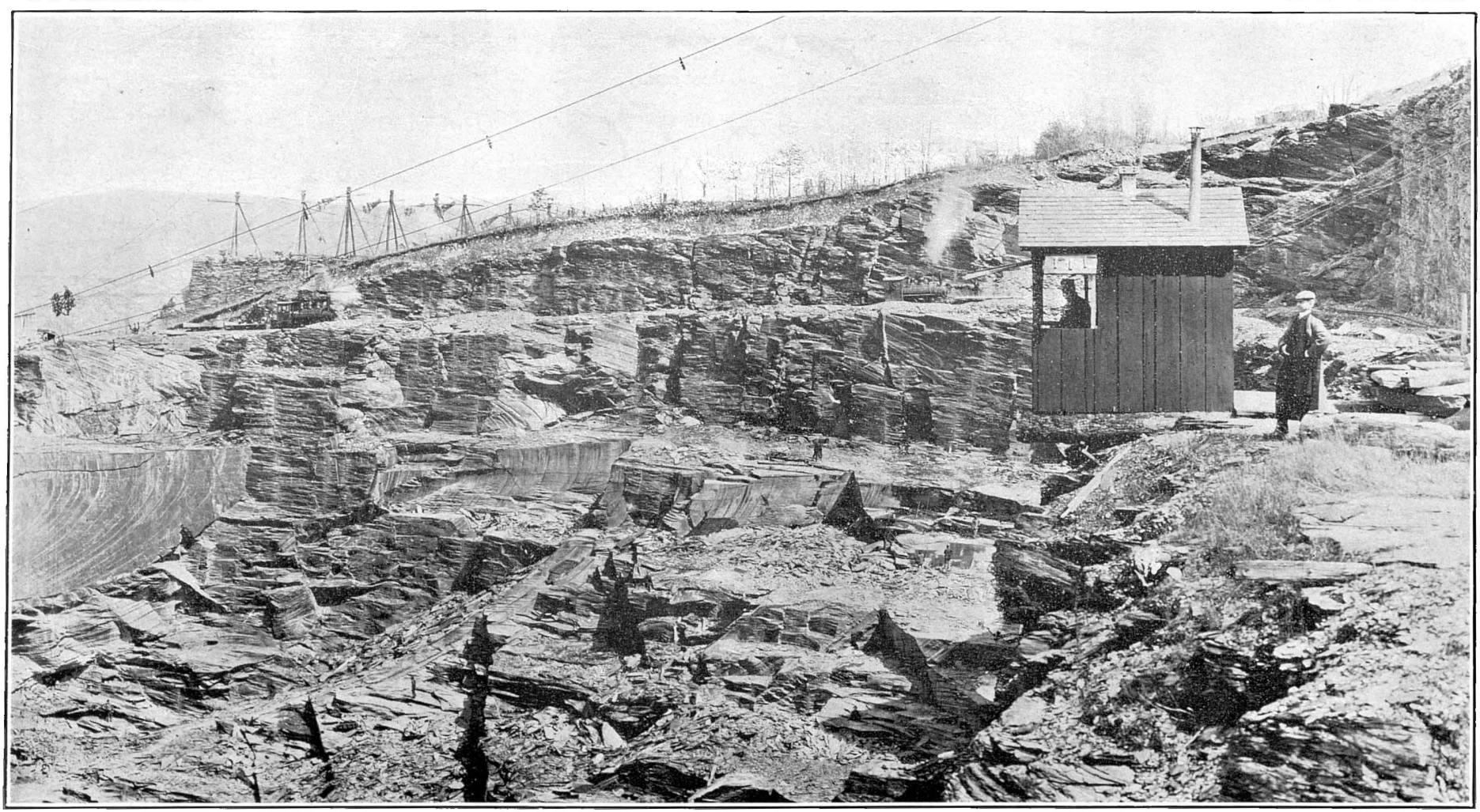

OLD BANGOR SLATE QUARRY, BANGOR, PA., NORTH-NORTHEAST END

Showing the close overturned syncline crossed by almost horizontal cleavage. Courtesy of Jay $S$. Moyer. 



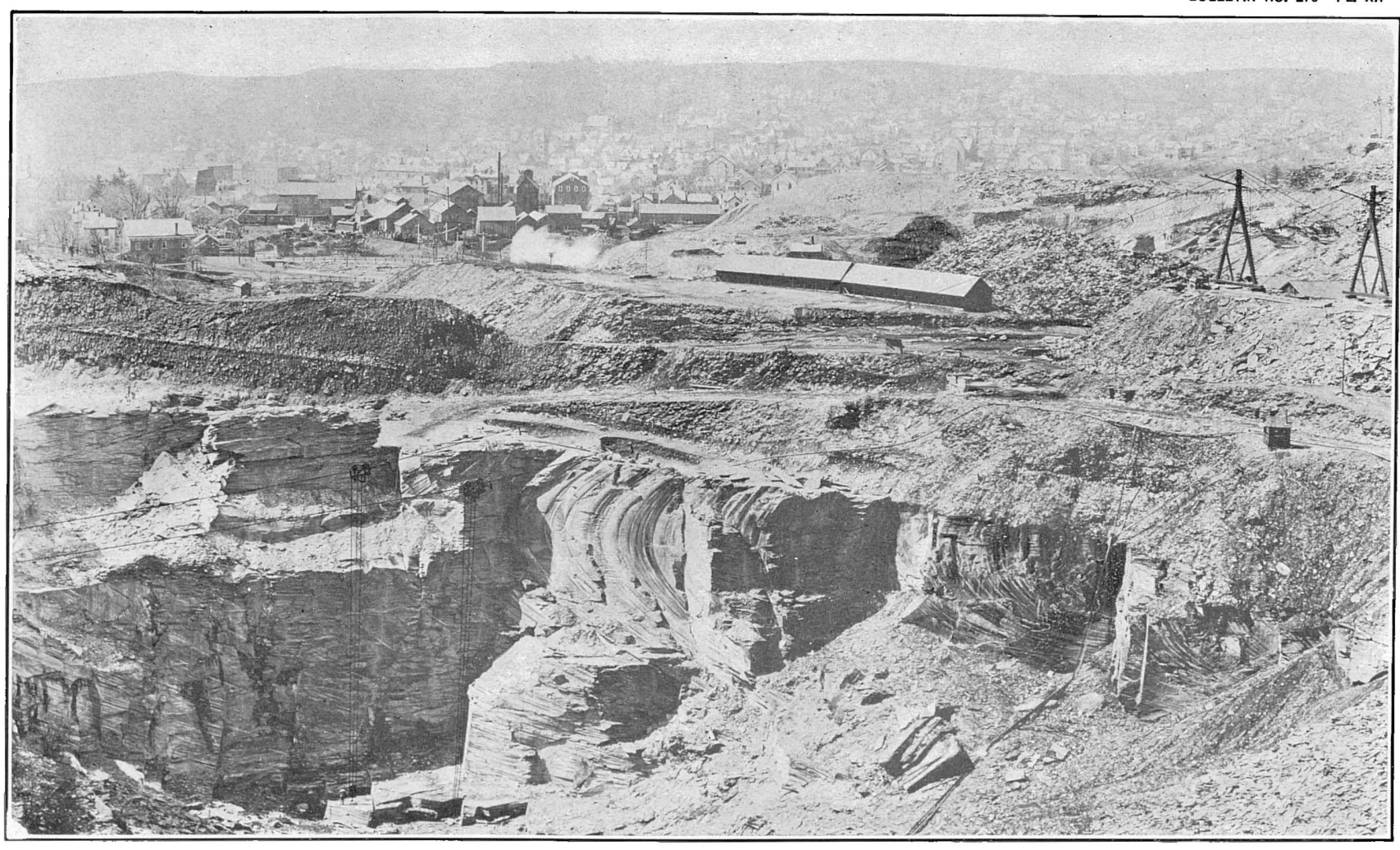

OLD BANGOR SLATE QUARRY, BANGOR, PA., SOUTH-SOUTHWEST END.

Showing the eroded overturned close syncline crossed by almost horizontal cleavage. Courtesy of Jay S. Moyer. 

sometimes in a lens of chlorite; some large plates of muscovite and of chlorite interleaved with muscovite, up to $0.06 \mathrm{~mm}$., and rarely a zircoh fragment, $0.03 \mathrm{~mm}$.

The constituents of this slate, arranged in descending order of abundance, appear to be muscovite (sericite), carbonate, quartz, kaolin, pyrite, chlorite, rutile, magnetite, and carbonaceous matter or graphite.

The final results of Professor Merriman's physical and chemical tests of "Old Bangor" slate are given here for convenience of reference: Strength (modulus of rupture), 9,810 pounds per square inch; toughness (ultimate deflection on supports 22 inches apart), 0.312 inch; density (specific gravity), 2.780; softness (amount in grains abraded by 50 turns of a small grindstone), 128; porosity (per cent of water absorbed in twenty-four hours), 0.145 ; corrodibility (per cent of weight lost in sixty-three hours in acid solution composed of 98 per cent $\mathrm{H}_{2} \mathrm{O}, 1$ per cent $\mathrm{HCl}, 1$ per cent $\mathrm{SO}_{3}$ ), 0.446. Per cent of lime, 4.38; computed carbonate of lime, 7.82 per cent; computed carbonate of magnesia, 5.65 per cent. $a$

The product from the large beds is used for roofing, but that from the ribboned beds goes into mill stock.

Quarries of the North Bangor. Slate Company.-The large quarry is about 200 feet square and 350 feet deep. The folded beds strike about N. $60^{\circ}$ E. and the cleavage dips southwestward, at an angle of $15^{\circ}$. The total thickness of good slate here, measured across the cleavage, is 300 feet. In the smaller quarry the thickest bed measures 9 feet, and is reserved for blackboards.

In a quarry adjacent to the first of these two quarries, operated by Auld \& Conger, a completely overturned syncline, several hundred feet from northwest to southeast, is exposed on the east-northeast wall, with an almost horizontal cleavage.

The slate from these quarries is very dark gray, and to the unaided eye has a fine texture and a very smooth cleavage surface, with but slight luster. It is somewhat carbonaceous or graphitic, and contains some magnetite. The sawn edge shows pyrite. It effervesces somew hat freely with cold dilute hydrochloric acid; is sonorous, and has an argillaceous odor.

Specimens from the North Bangor Slate Company's quarry show, under the microscope, a matrix of muscovite (sericite) with a somewhat brilliant aggregate polarization and a general uniformity in size of particles. The aggregate polarization is partly obscured by the very abundant carbonate. Quartz fragments are not very abundant and measure up to $0.04 \mathrm{~mm}$. There are some chlorite scales up to $0.09 \mathrm{~mm}$., and about three hundred and sixty spherules of pyrite, measuring up to $0.01 \mathrm{~mm}$. to each square millimeter. Also carbonaceous matter or graphite and very abundant rutile needles.

The constituents, arranged in descending order of abundance, appear to be muscovite (sericite), carbonate, quartz, kaolin, pyrite, chlorite, magnetite, rutile, carbonaceous matter or graphite. In a black-ribboned piece from the same quarries the half-inch ribbon shows much carbonaceous matter and many spherules of pyrite. The quartz particles and the plates of carbonate are larger in the ribbon than in the adjacent slate. The product of this company's quarries is used for blackboards, billiard tables, fireboards, stationary tubs, well covers, tiles, lathe work, etc.

East Bangor.-The large quarry of the East Bangor Consolidated Slate Company measures 350 feet along the strike and 700 feet across by 130 feet in depth. The'beds $\operatorname{dip} 5^{\circ} \mathrm{NNE}$. and the cleavage $15^{\circ}$ to $20^{\circ} \mathrm{SSW}$. The main joints strike north and south and undulate in a general vertical direction. The grain strikes N. $50^{\circ}-60^{\circ} \mathrm{W}$. Ribbons are frequent. The slate is very dark-bluish gray, and to the unaided eye has a fine texture and a somewhat fine but almost lusterless cleavage surface. It is both carbonaceous, or graphitic, and magnetitic. The sawn edge shows a little pyrite. It 
effervesces slightly with cold dilute hydrochloric acid; is sonorous, and has a scarcely perceptible argillaceous odor.

Under the microscope a specimen taken between "ribbons" shows a matrix of muscovite (sericite) with a brilliant aggregate polarization, somewhat obscured by carbonate, a texture a little finer than that of "Old Bangor" slate, but carbonate as abundant as in that. Not very much quartz in grains measuring up to 0.04 by 0.02 $\mathrm{mm}$; about seventeen scales of chlorite, with interleaved muscovite, to each square millimeter, measuring up to 0.07 by $0.03 \mathrm{~mm}$., exceptionally 0.08 by $0.04 \mathrm{~mm}$.; about six hundred spherules of pyrite per square milimeter, measuring up to $0.008 \mathrm{~mm}$; rutile needles very abundant; carbonaceous or graphitic matter in fine particles.

The chief constituents of this slate, arranged in descending order of abundance, appear to be muscovite, carbonate, quartz, pyrite, chlorite, kaolin, rutile, carbonaceous matter or graphite, magnetite.

The product of this quarry is used both for roofing and for mill stock, but not for blackboards, as the 9 -foot bed is crossed by ribbons. The roofing slates are said to show comparatively little discoloration after thirty years' exposure.

Heimbach.-The Heimbach quarry about $1 \frac{1}{2}$ miles northeast of Slatington, but in Northampton County, is now operated by Jay S. Moyer \& Co. There is a thick bed here known as the "Heimbach big bed," which is very dark gray and less bluish than "Old Bangor." To the unaided eye it has a fine texture and a somewhat fine but almost lusterless cleavage surface. It contains an exceedingly small amount of magnetite; effervesces with cold dilute hydrochloric acid, and is sonorous.

Under the microscope it shows a matrix of muscovite (sericite), with but faint aggregate polarization owing to the abundance of carbonate, which much exceeds that in the "Old Bangor" slate. The cleavage is considerably finer and there is greater regularity in the size of particles than in that slate. There are a few chlorite scales up to 0.06 by 0.04 . Very little quartz is seen, in grains reaching only $0.036 \mathrm{~mm}$. Pyrite spherules measure up to $0.012 \mathrm{~mm}$. and number about 116 per square millimeter. Rutile needles are very abundant. The usual carbonaceous matter is seen.

The constituents of the "Heimbach big bed," arranged in descending order of abundance, appear to be muscovite (sericite), carbonate, quartz, pyrite, chlorite, rutile, carbonaceous matter, magnetite, but the carbonate is larger in amount than in some slates in which its relative position is the same.

There is also in the same quarry a 6-foot bed, which is quite black, more so than any of the Northampton or Lehigh County slates. It has, to the unaided eye, a somewhat fine texture and cleavage surface with a slight luster. It shows pyrite on the sawn edge, is quite carbonaceous or graphitic, very slighly magnetitic, effervesces in cold dilute hydrochloric acid, is sonorous, and has a slight argillaceous odor.

Under the microscope the "Heimbach black bed" shows a fine matrix of muscovite (sericite), with but faint aggregate polarization owing in part to the very large amount of carbonate and carbonaceous matter. The number of quartz fragments is relatively small and they measure up to $0.028 \mathrm{~mm}$. There are chlorite scales up to $0.06 \mathrm{~mm}$. Spherules of pyrite measure up to $0.008 \mathrm{~mm}$., exceptionally $0.017 \mathrm{~mm}$. and number about 135 per square millimeter. Rutile needles abound. Rarely a scale of hematite is seen.

The chief constituents of this slate, arranged in descending order of abundance, appear to be muscovite (sericite), carbonate, quartz, carbonaceous matter and graphite(?), pyrite, chlorite, rutile, magnetite, the percentage of carbonate being, however, large.

The principal difference between the Heimbach and "Old Bangor" slate is in the larger amount of carbonate, lesser amount of pyrite, and the finer structure of the former, judging from the microscopic evidence.

Pen Argyl. - The Albion quarry at Pen Argyl is regarded as being near the bottom of the "soft vein" belt. It measures 650 feet along the strike, 600 feet across it, 


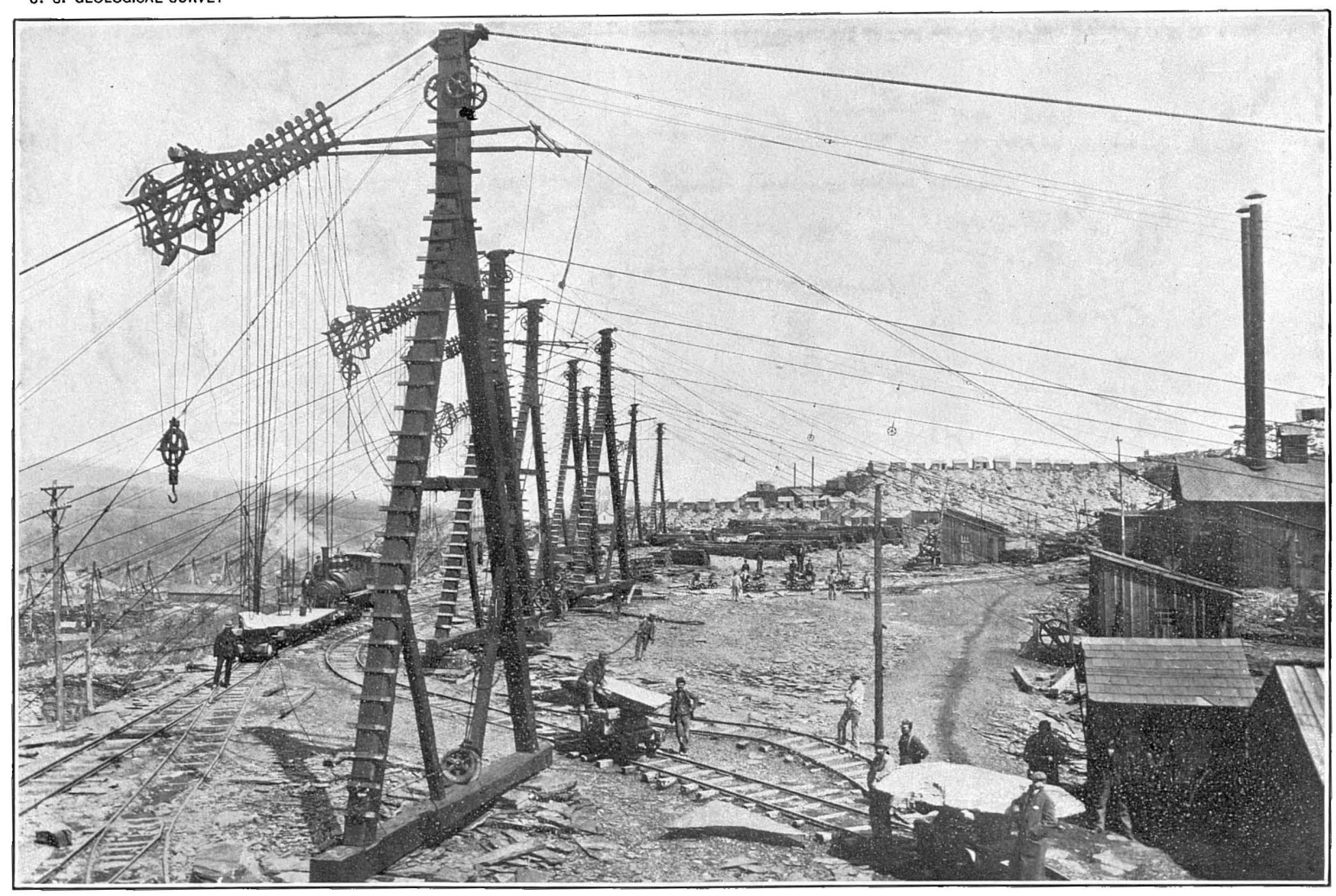

DERRICKS AND CARRIERS, OLD BANGOR SLATE QUARRY, BANGOR, PA.

In background at right the slate splitters and trimmers' shanties on the dumps. Courtesy of Jay S. Moyer. 

and 390 feet in depth. In 1904 it was operated by two companies, Wm. Lobb \& Sons at the western end and Stephen Jackson \& Co. at the eastern end. The structure is an S-shaped fold overturned to the north-northwest. The bedding strikes $\mathrm{N} .58^{\circ}-60^{\circ} \mathrm{E}$.; cleavage at the north-northwestern edge dips $10^{\circ} \mathrm{S}$., halfway down about $10^{\circ} \mathrm{N}$., and at the bottom about $40^{\circ} \mathrm{S}$. The grain is at right angles to the ribbon. At the north-northwestern edge of the quarry is a series of hard beds 40 feet thick. Under the microscope this rock shows no aggregate polarization and consists of the following minerals, named in order of diminishing abundance: Carbonate, quartz, chlorite, carbonaceous matter, muscovite, pyrite, and rarely plagioclase feldspar. 'It is a clay slate. Some of the beds are said to measure 20 feet between ribbons. There is an exceptional bed, 44 inches thick, of a dark, slightly greenish gray slate of superior quality, described beyond. Vein matter on the dumps consists of vein quartz and calcite, the former predominating. Associated with these veins are plicated very quartzose ribbons traversed by a coarse slip cleavage and also brecciated. Black slaty material has been pressed into the faults of the slip cleavage. One of these quartz masses was 20 feet thick and extended the entire length of the quarry.

The chief product of the Albion quarry is a very dark-gray slate which, to the unaided eye, has a fine texture and a roughish almost lusterless cleavage surface. It is somewhat carbonaceous or graphitic and magnetitic, shows pyrite on the sawn edge, effervesces slightly with cold dilute hydrochloric acid, considerably in the ribbon, and is sonorous.

Under the microscope this slate shows a matrix of muscovite (sericite), with brilliant aggregate polarization, somewhat obscured by abundant carbonate in plates and rhombs. The amount of carbonate is less than in the specimens from the Old Bangor and North Bangor quarries. Quartz is not very abundant, in grains measuring up to 0.04 , rarely $0.09 \mathrm{~mm}$. Scales of chlorite, interleaved with muscovite, are conspicuous, lying transverse to the cleavage, sometimes forming lenses with their long axes parallel to the cleavage, measuring up to 0.14 by $0.07 \mathrm{~mm}$. and numbering about 20 per square millimeter. Pyrite spherules occur up to $0.01 \mathrm{~mm}$. and average about 150 per square millimeter. There is finely disseminated carbonaceous (or graphitic) matter and a great abundance of rutile needles.

The mineral constituents, arranged in descending order of abundance, appear to be muscovite (sericite), carbonate, quartz, chlorite, pyrite, rutile, carbonaceous matter, magnetite. The carbonate, although second, is not as abundant as in specimen from "Old Bangor" quarry.

The results of Professor Merriman's physical and chemical tests of the dark-gray ("black") slate from this quarry are here given for convenience of reference: Strength (modulus of rupture), 7,150 pounds per square inch; toughness (ultimate deflection on supports 22 inches apart), 0.270 inches; density (specific gravity), 2.775; softness (amount in grains abraded by 50 turns of a small grindstone), 80; porosity (per cent of water absorbed in 24 hours), 0.238 ; corrodibility (per cent of weight lost in 63 hours in acid solution), 0.547; per cent of lime, 4.09; computed carbonate of lime, 7.40 per cent; computed carbonate of magnesia, 4.41 per cent. $a$

The dark greenish-gray slate of the Albion quarry has to the unaided eye a somewhat granular texture and a roughish and almost lusterless cleavage surface. It is not perceptibly carbonaceous or graphitic, but is somewhat magnetitic. The sawn edges show pyrite. It effervesces slightly with cold dilute hydrochloric acid, and is sonorous.

Under the microscope it shows a matrix of muscovite (sericite), with brilliant aggregate polarization. Quartz fragments measure up to $0.09 \mathrm{~mm}$. There is considerable carbonate. There are chlorite scales, interleaved with muscovite, lying trans- 
verse to the cleavage and parallel to the grain; also chlorite scales transverse both to grain and cleavage, with inclusions of needle-like crystals; probably rutile, crossing one another, usually at $60^{\circ}$ or $120^{\circ}$. All these chlorite scales average about 18 per square millimeter, and measure up to $0.17 \mathrm{by} 0.1 \mathrm{~mm}$. The pyrite spherules measure up to $0.01 \mathrm{~mm}$, and number about 150 per square millimeter. Rutile needles also occur.

These constituents, arranged in descending order of abundance, appear to be muscovite (sericite), carbonate, quartz, chlorite, pyrite, rutile, and magnetite.

The product of the Albion quarry, at least that of the western end, is used for roofing.

Weathering at Pen Argyl.-Some of the other quarries at Pen Argyl show the passage of the black slate by weathering into a yellowish light brown, and even white shaly substance. The dumps afford specimens showing all gradations from black slate to white rock. The weathered zone in these quarries measures up to 40 feet in thickness. At one of them the beds of the truncated southern limb of an overturned syncline dip about $55^{\circ}$ south, while the cleavage dips less than $10^{\circ}$ in the same direction. . The weathered top measures between 30 and 40 feet, and is covered with from 5 to 10 feet of subsoil. The weathering acids, taking advantage of the position of the bedding, have followed one of the ribbons and penetrated the workable slates to a depth of 60 feet below the weathered zone, and have also commenced to work horizontally along the cleavage. This has resulted in the formation along the ribbon of a central bed of reddish-yellow ocher about 1 foot thick, with a 6 -inch band of white on either side of it. The white portions here probably represent less ferruginous parts of the original sediment, and not a later stage of weathering, for similar alternations of yellowish and white belts of weathered material occur in hand specimens crossing the cleavage. The workable black slate is thus traversed here by a 2-foot bed of yellow and white ochraceous material at an angle of $65^{\circ}$ to the cleavage as the effect of weathering upon material and structure. The process here is mainly decarbonization. (See further, on the subject of weathering; p. 37.)

In this connection it should be stated that in the "soft vein" quarries generally, judging from the dumps, the amount of iron and lime in the ribbon varies greatly. In some cases pyrite or siderite predominates and limonitic staining ensues, in others lime and a white calcareous crust forms. The slate flags on the sidewalks in the village of Bangor wear along the ribbons more rapidly than along the slaty portions.

Chapman.-This is in the "hard vein" belt. The principal quarry is operated by the Chapman Siate Company. It measures from 700 to 800 feet along a longitudinal joint striking N. $63^{\circ}$ E. across it, and is about 200 feet wide and 300 feet deep. In the center of the quarry is a completely overturned close fold, syncline, or anticline, still visible on the south-southeast wall of the quarry, striking $\mathrm{N}$. $75^{\circ}-78^{\circ} \mathrm{E}$, pitching gently eastward; but the lower limb of this fold opens out on the eastnortheast and west-southwest walls so as to dip steeply northwest. This fold is crossed by cleavage striking $\mathrm{N}$. $65^{\circ} \mathrm{E}$. and dipping $14^{\circ}-15^{\circ} \mathrm{SSE}$. The principal joints are longitudinal, striking N. $63^{\circ}$ E. and dipping $90^{\circ}$, forming two of the sides of the quarry. The grain strikes $\mathrm{N} .37^{\circ}-53^{\circ} \mathrm{W}$. and dips $90^{\circ}$. The largest bed, which, although containing very small ribbons, can be used for roofing slate, measures 16 feet. The number of ribbons exposed on the east-northeast wall, where the fold opens out, is 112, averaging a little over 2 per foot of slate. $a$

Some quartz veins lying in the cleavage show a columnar structure parallel to the side of the vein. The "top" in an adjacent quarry of the same company measures fully 50 feet.

The slate is very dark gray, but is crossed by frequent ribbons a trifle darker and measuring from one-eighth to one-half inch, which, however, scarcely deflect the 


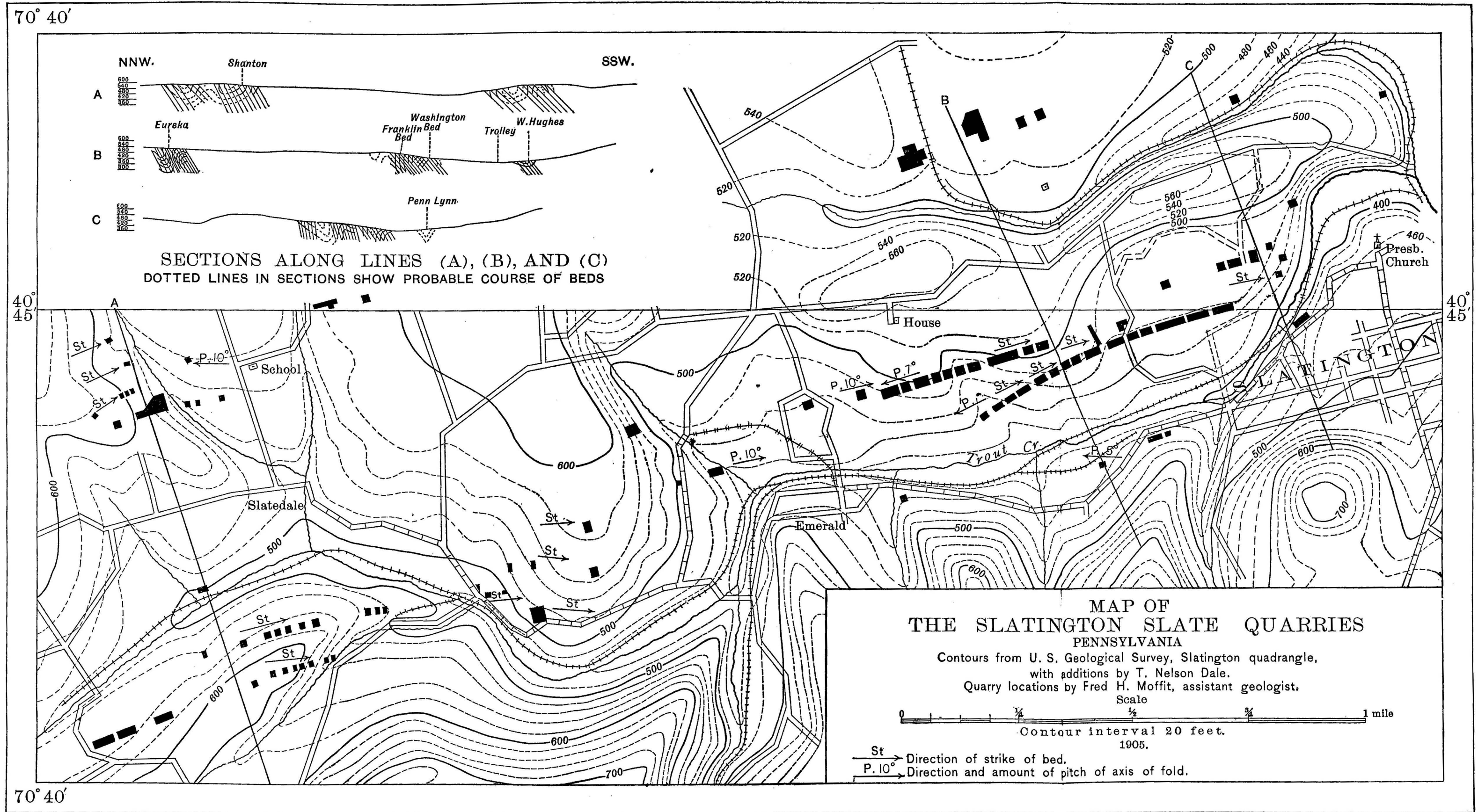



cleavage. To the unaided eye it has a fine texture and a slightly roughish and slightly lustrous cleavage surface. It is both graphitic (or carbonaceous) and magnetitic. The sawn edge shows pyrite. Under cold dilute hydrochloric acid there is a slight effervescence, but more in the ribbon. It is sonorous, and discolors but slightly in thirty years exposure. E. H. S. Bailey gives the specific gravity as 2.79. For Professor Merriman's recent tests of this slate see page 122 .

Under the microscope the Chapman slate shows a matrix of muscovite (sericite) with a brilliant aggregate polarization not obscured by carbonate. A ribbon of coarse materials, $0.62 \mathrm{~mm}$. wide, crossing the cleavage at an angle of $14^{\circ}$, possesses aggregate polarization. There are some large lenses of coarse quartz and carbonate in the cleavage. There is considerable carbonate throughout, in plates and rhombs, but less than in "Old Bangor" slate. Quartz up to $0.06 \mathrm{~mm}$., pyrite spherules up to $0.02 \mathrm{~mm}$. and numbering from 200 to 600 per square millimeter, about 55 scales of chlorite, with interleaved muscovite, per square millimeter, lying across the cleavage and measuring generally up to 0.08 by $0.04 \mathrm{~mm}$., graphitic or carbonaceous matter in fine particles, abundant rutile needles, rare grains of plagioclase feldspar. The ribbon contains more abundant and coarser quartz, carbonate, chlorite, and carbonaceous matter than the rest.

The important constituents, arranged in descending order of abundance, appear to be muscovite (sericite), quartz, carbonate, pyrite, chlorite, rutile, carbonaceous matter or graphite, magnetite.

The product of this quarry was formerly used largely for flagging, posts, steps, etc., and because of its hardness had to be cut with diamond saws which operated horizontally, but owing to the competition of sandstone flagging and the high price of diamonds this outlet is closed and the product is now used exclusively for roofing slate, for which, however, only selected material is available.

\section{LEHIGH COUNTY.}

Geological relations. - The slate quarries of Lehigh County all belong in the "soft vein" belt. The relation of the "soft vein" slate to the shale of the same formation is well exposed near Lehigh Gap, on the border of the county. On the eastern side of the gap the outcrop of the Hudson formation that is nearest to the Oneida conglomerate is a black shale that occurs in alternating thick and thin beds. The thick ones, being entirely devoid of cleavage, weather into shelly fragments, while the thin ones, owing to the intersection of an incipient slaty cleavage with the bedding foliation, break up into stick-like fragments. Under the microscope the thin beds prove to be an aggregate of muscovite scales, quartz grains, and carbonaceous particles, with some pyrite spherules and limonite specks. Here and there the beginning of a slaty cleavage foliation is indicated by short stringers of fibrous muscovite lying at right angles to the bedding, but otherwise there is no alignment of particles and the rock is a typical shale. A hundred feet south of the locality described a southwarddipping slaty cleavage predominates, and the north ward-dipping bedding is only shown by an occasional ribbon. Therefore within a space of 200 feet the transition from a shale to a slate can be observed. In the slate the amount of secondary mica has greatly increased and the clastic particles of the shale have been forced into the same parallelism of arrangement.

In weathering, the Lehigh slates undergo the same transformations as those of Northampton County. The black slate first passes into a soft yellowish-brown ochraceous rock, which later becomes nearly white, and finally passes into a white micaceous clay, the "shale clay" of the limonite and fire-clay pits. But these changes probably required many centuries. See discussion of chemistry of slate, p. 37 .

The Slatington quarries.-The slate quarries of Lehigh County are now confined to an area comprising about 3 square miles along Trout Creek and its tributaries. This 
tream empties into the Lehigh from the west at Slatington. The accompanying map (PI. XVI), includes all the quarries about Slatington which were in operation in 1902,45 in number, together with 50 abandoned ones. The older quarries have

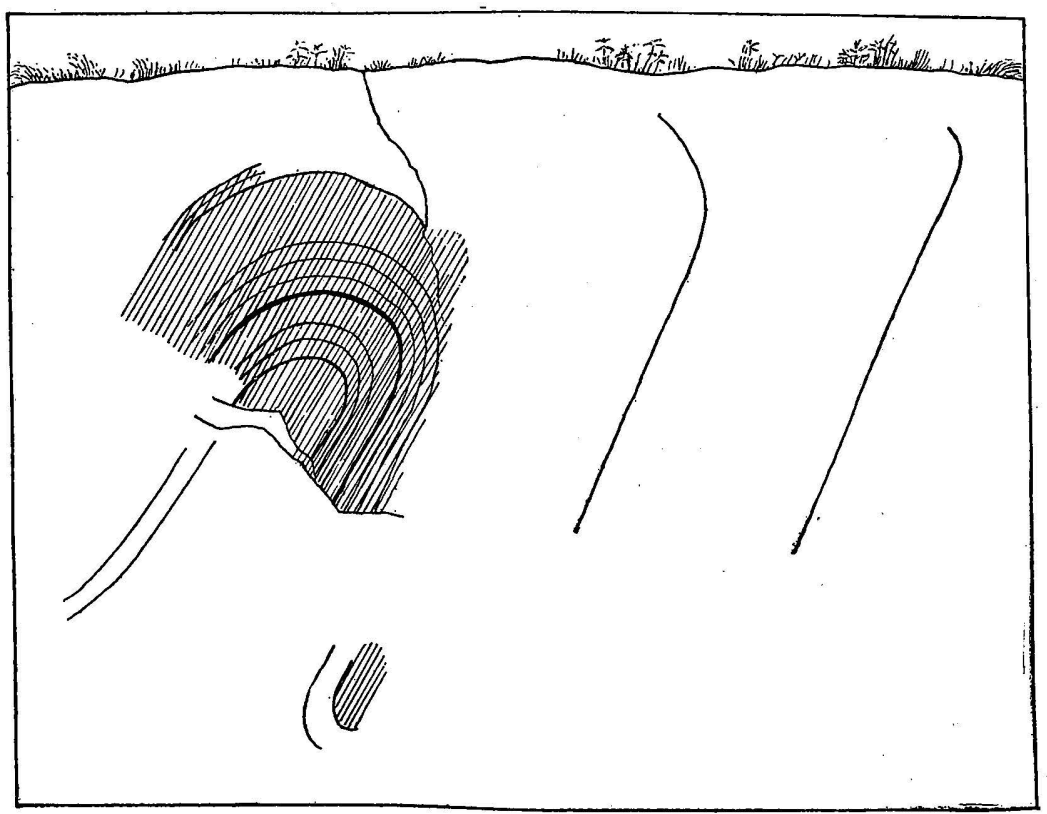

Fig. 6.-Sketch of anticline in Provident Slate Company's quarry, near Slatington, Pa. Looking west. Width represented, 50 feet.

reached a depth of about 300 feet. The map shows the exact location of these quarries, their approximate dimensions at the surface, the strike of the beds, and both the direction and angle of the pitch of the folds. The lateral deflection of the strike amounts in places to $10^{\circ}$, if not a little over, and the pitch ranges from $5^{\circ}$ to $10^{\circ}$.

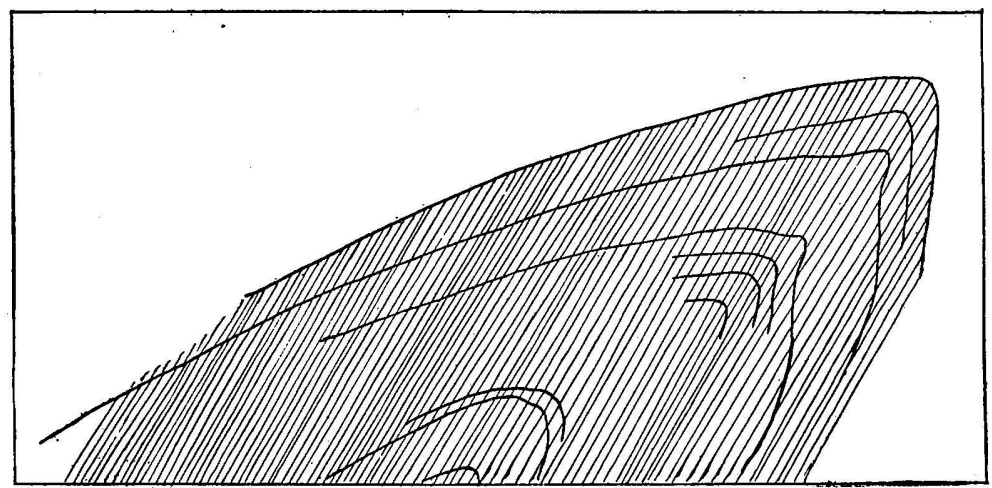

Fig. 7. Sketch of anticline in old quarry north of Slatington, Pa. Looking west. Height represented, 25 feet.

The character of the folds in these quarries is shown in Pls. XVII, XVIII, and figs. $6,7,8,9$. The relation of the workable beds to the ribbons is shown in Pl. XIX. The strike ranges from N. $40^{\circ}$ E. to N. $90^{\circ}$ E., and N. $86^{\circ}$ W. The cleavage strike varies from $\mathrm{N}$. $74^{\circ}$ to $85^{\circ} \mathrm{E}$., and its dip from S. $5^{\circ}$ to $16^{\circ} \mathrm{E}$., at angles ranging 


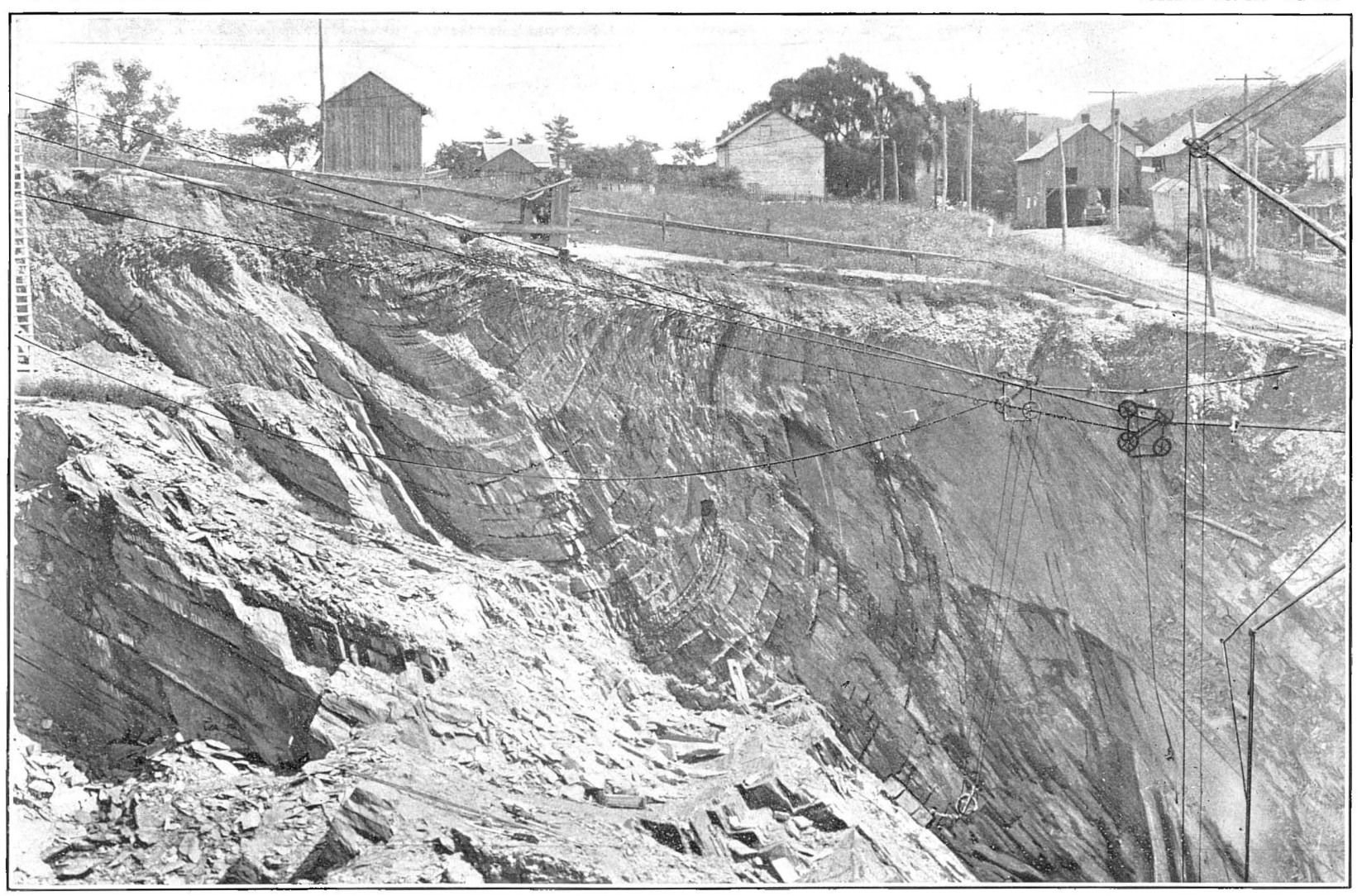

BLUE MOUNTAIN SLATE QUARRY NEAR SLATINGTON, PA.

Seen looking east, showing the character of the syncline and the bending over southward or the cleavage at the surface, probably due to the friction and weight of the glacier. 



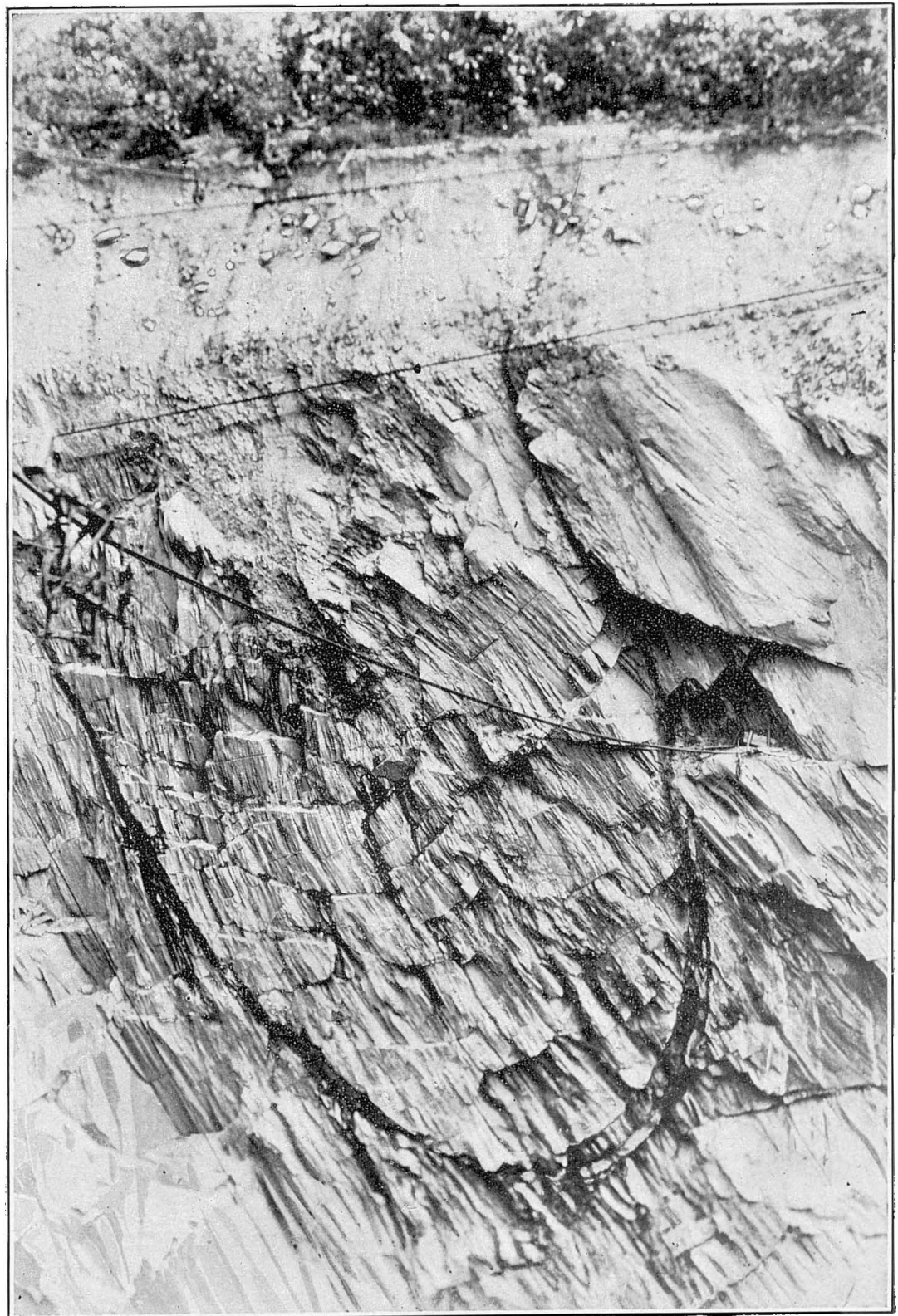

EUREKA SLATE QUARRY NEAR SLATINGTON, PA.

North part, seen looking east, showing an eroded northward-inclined close syncline crossed by cleavage and curved joints, and overlain by glacial deposits. The cleavage within the syncline appears to be surved also. 

from $35^{\circ}$ to $75^{\circ}$. There is sometimes a difference in the angle of the cleavage dip in adjacent beds. The curvature of the cleavage at the "Old William Hughes" quarry amounts to a change of $20^{\circ}$ in 25 feet of slope. There is apt to be a little curvature of the cleavage on either side of the ribbon. There is a conspicuous system of dip joints striking about north-south, some of which are shown in Pls. XVII

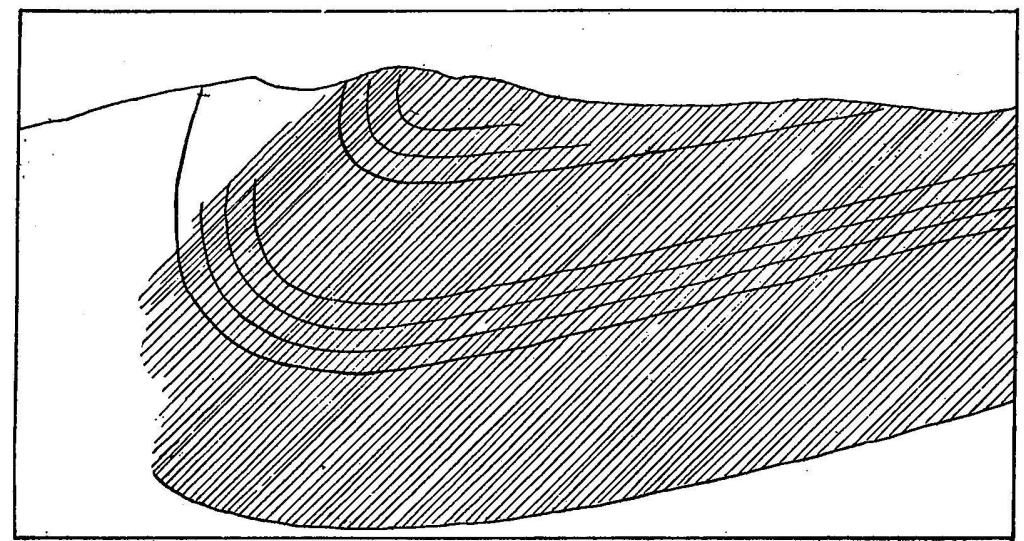

Fig. 8.-Sketch of syncline at William Hughes's quarry, near Slatington, Pa. Looking west. Length, 80 feet. Upper bed over 10 feet thick; lower bed 15 feet thick, but with marked curvature of cleavage.

and XVIII. There are also strike joints which sometimes undulate like bedding planes, as at the Eureka quarry (Pl. XVIII).

The names of the Slatington beds are, from south to north, the Williamstown, Blue Mountain, Trout Creek, Washington, Little Franklin, Big Franklin, Mammoth, New Bangor, Snowdon, and Eureka. It is uncertain whether some of these are not

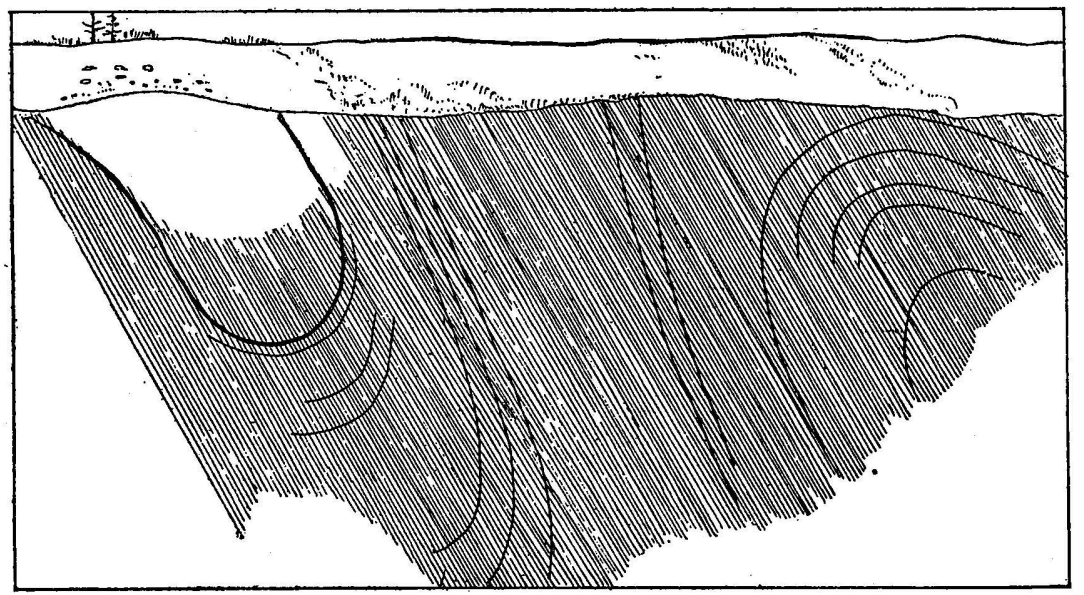

Fig. 9. $\rightarrow$ Sketch of folds at Eureka quarry, near Slatington, Pa. Looking east. Length, 350 feet; depth, 225 feet. The upper part of the syncline is shown in PI. XVIII.

duplications, for the structure of the belt, as shown in the section on Pl. XVI, indicates that they may be, and their relations have never been worked out mathematically. Examples of these beds ("veins") are the Washington, which at the Hazel Dell quarry averages 27 feet in thickness or 40 feet measured along the cleavage, and the Franklin, at the "Old Franklin" quarry, which consists of an upper bed of 28 
feet and a lower one of 35 feet, separated by about 25 feet of small ribboned material, the measurements being taken along the cleavage. In general, the beds range from 3 to 30 feet in thickness, measured at right angles to the bedding.

The Slatington slate is a very dark bluish gray. To the unaided eye it has a somewhat fine texture and cleavage surface, but it is almost lusterless. It is carbonaceous or graphitic and slightly magnetitic. The sawn edges show little if any pyrite. It effervesces in cold dilute hydrochloric acid, is sonorous, and has some argillaceous odor. After prolonged exposure this slate becomes at first a dark gray and finally various shades of cream and coffee color, but the rapidity and degree of discoloration differ in different beds. Fissility fine.

Under the microscope it shows a matrix of muscovite (sericite) with a brilliant aggregate polarization, obscured, however, by much carbonate and carbonaceous matter. There are many angular grains of quartz up to 0.04 ; rarely one of plagioclase; a few scales of chlorite, interleaved with muscovite, or of each separately, up to $0.08 \mathrm{~mm}$; ; spherules of pyrite up to 0.012 , rarely $0.02 \mathrm{~mm}$., numbering about 130 per square millimeter; very abundant rutile needles.

The principal constituents, arranged in descending order of abundance, appear to be muscovite (sericite), carbonate, quartz, kaolin, pyrite, rutile, carbonaceous or graphitic matter, magnetite.

The following analyses were made by Dr. W. F. Hillebrand, chemist of the United States Geological Survey-A from the Lower Franklin bed, Old Franklin quarry, Slatington; B from the Washington bed, Hazel Dell quarry No. 1, Slatington.

Analyses of slates from Lehigh County, Pa.

\begin{tabular}{|c|c|c|}
\hline & A (complete). & B (partial). \\
\hline $\mathrm{SiO}_{2}$ (Silica) $\ldots \ldots \ldots \ldots \ldots \ldots \ldots \ldots . . . . . . . .$. & 56.38 & 56.85 \\
\hline 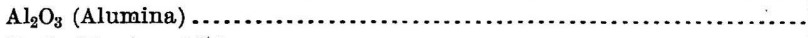 & 15.27 & - $a 15.24$ \\
\hline 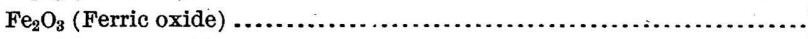 & $b 1.67$ & \\
\hline 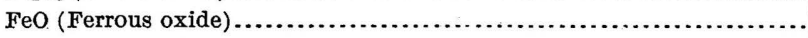 & $b 3.23$ & $c 5.52$ \\
\hline 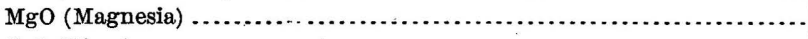 & 2.84 & 2. 93 \\
\hline 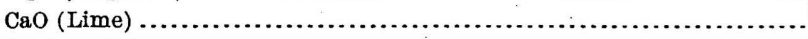 & 4.23 & 4. 24 \\
\hline 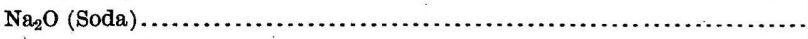 & 1.30 & 1.38 \\
\hline 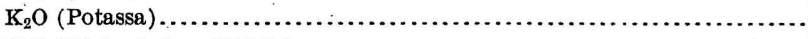 & 3.51 & 3.34 \\
\hline 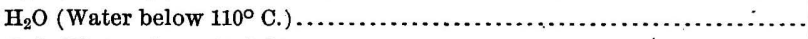 & .77 & \\
\hline 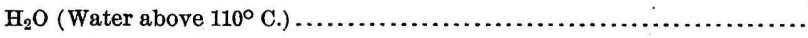 & . 4.09 & Not est. \\
\hline 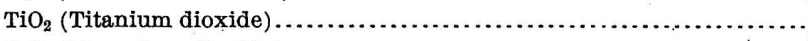 & .78 & .84 \\
\hline 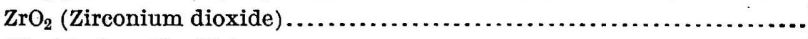 & Trace? & \\
\hline 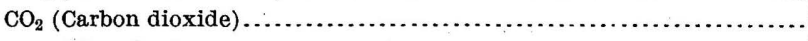 & 3.67 & 3.58 \\
\hline 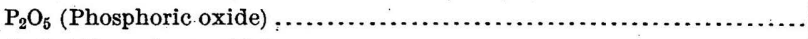 & .17 & $(d)$ \\
\hline 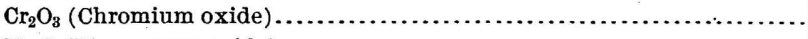 & Trace? & Trace? \\
\hline 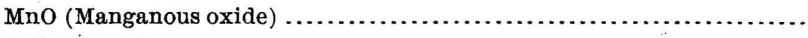 & .09 & Not est. \\
\hline 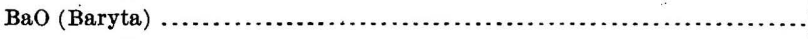 & .08 & Not est. \\
\hline 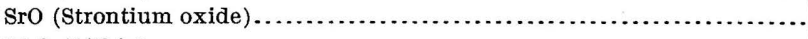 & Trace. & Not est. \\
\hline 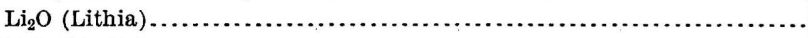 & Trace. & Not est. \\
\hline 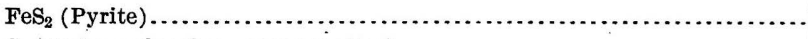 & $e 1.72$ & $e 1.72$ \\
\hline \multirow[t]{2}{*}{ 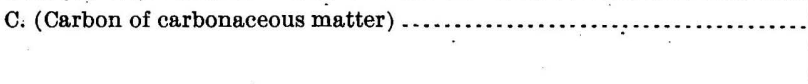 } & .59 & Not est. \\
\hline & 100.39 & 96.12 \\
\hline 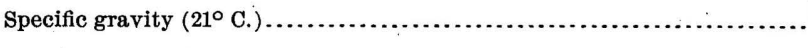 & 2.783 & 2.780 \\
\hline
\end{tabular}

The considerable amount of carbonate indicated both by the analyses and the microscopic examination and the discoloration due probably to the ferrous part of that carbonate are objectionable features in the Slatington slates, but their fine cleav- 


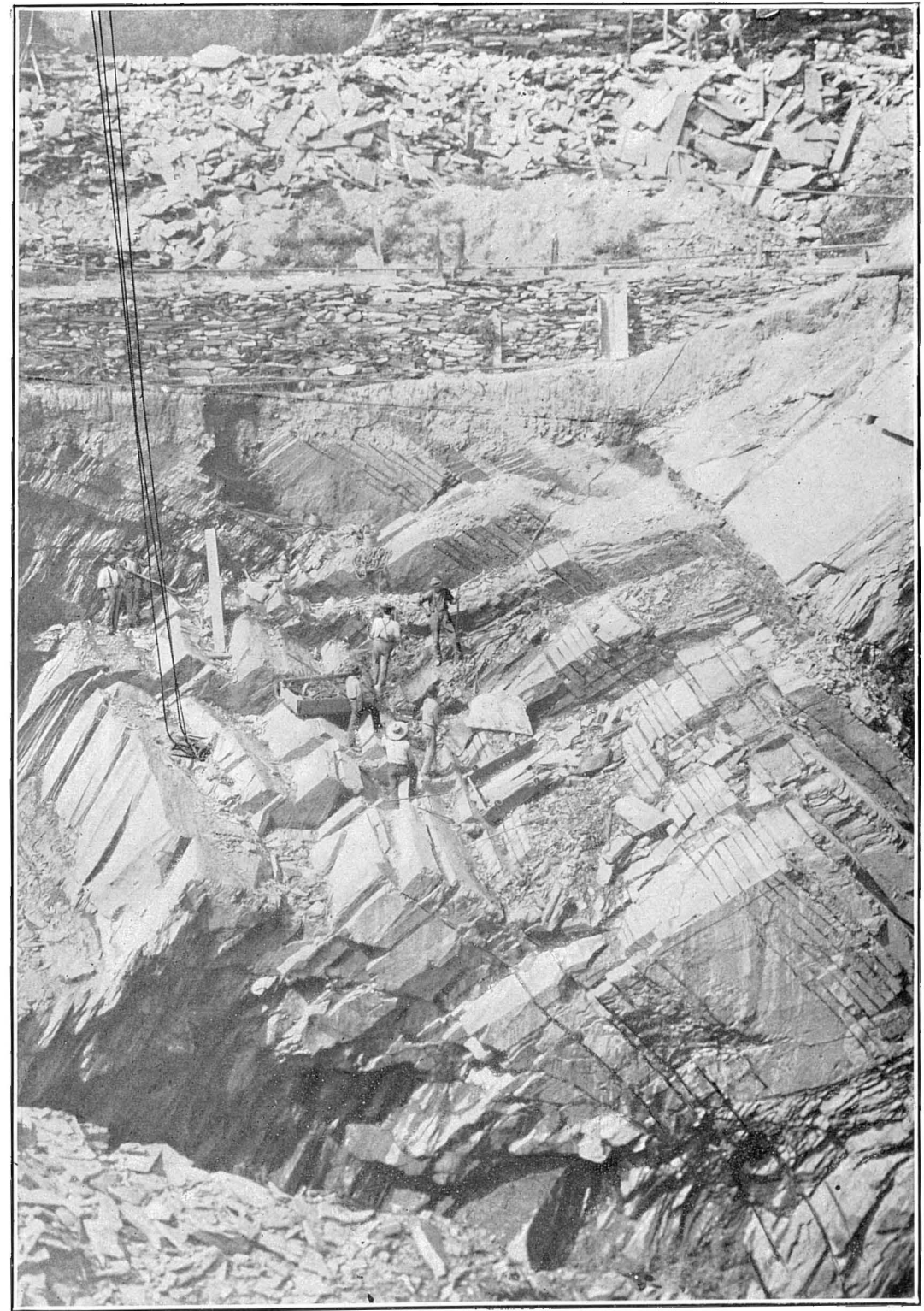

SLATE QUARRY NEAR SLATINGTON, PA.

Seen looking west, showing workmen engaged in clearing the "ribboned" slate from the surface of a thick workable bed. 

age and the relative facility with which they are quarrieci make it possible to supply them at low figures. On the other hand they are res.arkably well adapted by their softness and the thickness of the beds for mill-stock purposes and particularly for blackboards and other indoor objects.

All the more important features of the slates of Pennsylvania will be found in tabular form in the section on the comparative characteristics of slates (p. 124).

\section{PENNSYLVANIA AND MARYLAND (PEACH BOTTOM) SLATE.}

This slate deposit seems to have derived its name from that of a small village onefourth mile west of the Susquehanna River, formerly a sort of a port in the now disused canal which follows the river. This village is in a triangular township of the same name; which is bounded by the Maryland line on the south, the river on the northeast, and in part by Muddy Creek on the northwest, and which forms the southeast corner of York County, Pa.

Geological relations.-The only available geological maps of the region are those of the two Pennsylvania geological surveys and of the Maryland geological survey. $a$

The slate forms a belt and low ridge from one-fifth to one-half mile wide, which extends from a point about a mile northeast of the Susquehanna, in the town of Fulton, in Lancaster County, Pa., in a southwest direction across the river and across Peach Bottom township in York County, and continues for about 3 miles in the same direction into the town of Cardiff, in Harford County, Md. Its total length is about 10 miles, of which 1 mile lies in Lancaster County, Pa., $1 \frac{1}{2}$ miles are submerged by the Susquehanna, $4 \frac{1}{2}$ are in York County, Pa., and about 3 miles are in Harford County, Md. Most of the quarry population is congregated along one street, which follows the western foot of the ridge. The northeastern part of this street is Delta, Pa.; the southwestern is Cardiff, Md.

For the literature of Peach Bottom slate the reader is referred to the writings of Rogers, Lesley, Frazer, Williams, Mathews, Merrill, and Merriman. $b$

The slate belt has on its northwest side a sericite-chlorite-quartz-schist (containing rounded grains of zircon), with a foliation striking N. $45^{\circ}$ E. and dipping southeast at an angle of $75^{\circ}$. A bout midway between Delta and Bryansville this schist is calcareous. According to the reports of the Second Pennsylvania Survey similar schists recur on the southeastern side of the slate belt, and the whole schist formation overlies in synclinal structure the older gneisses and serpentines which occur on either side of it; and these schists and the associated slate are classified as Cambrian, although no typical Cambrian fossils have as yet been found in them. There is a good exposure of the relations of the slate to the rocks on the southeast (referred to by Rogers) on the east side of Slate Point on the towpath along the Susquehanna. The slate here conformably underlies about 50 feet of slightly muscovitic quartzite, which was formerly quarried for canal construction, both rocks striking N. $45^{\circ}-50^{\circ}$ E., and dipping southeast at $70^{\circ}$. A little farther east this quartzite is followed by a coarsely plicated gneiss consisting of quartz, plagioclase, muscovite, hornblende, and epidote, and having the same strike and dip. Still farther east, nearly a quarter of a mile from the contact of the slate and quartzite, about 70 feet of slightly muscovitic quartzite crop out with a strike of N. $45^{\circ}-50^{\circ}$ E., dip $42^{\circ}$ SE., and are followed conformably by a gneiss like that previously described. These quartzites and

a Rogers, H. D., Geol. Pennsylvania, 1858; Frazer, Persifor, jr., York and Lancaster county sheets, Second Geol. Survey, Pennsylvania, Vol. CCC, Atlas, 1878, 1879; Mathews, E. B., Maryland Geol. Sur-

vey, vol. 2, Pl. XXX, 1898 .
b Rogers, H. D., Geol. Pennsylvania, vol. 1, 1858, pp. 188, 189; Frazer, Persifor, jr., Geol. Lancaster County, Second Geol. Survey Pennsylvänia, Vol. CCC, 1880, pp. 179-190, and Pls. VII, VIII; Williams, G. H., The petrography and structure of the Piedmont Plateau: Bull. Geol. Soc. Am. vol. 2, 1891, p. 304; Lesley, J. P., Second Geol. Survey Pennsylvania, Final Rept. vol. 1, 1892, pp. 136-141; Mathews, E. B., Maryland Geol. Survey, vol. 2, 1898, pp. 215-231, 239-241; Merrill, G. P., Treatise on rocks, rock weathering and soils, 1897, p. 229; also Stones for building and decoration, 3d ed., 1903; Merriman, M., The strength and weathering qualities of roofing slates, Trans. Am, Soc. Civ. Engrs., vol. 27, 1892, pp. 331-349; also vol. 32, 1894, pp. 529-539.

Bull. 275-06- -7 
gneisses apparently continue into Lancaster County, for in looking across the Sasquehanna from Slate Point a considerable thickness of light-colored rock can be seen overlying the slates there with a steep easterly dip. $a$

The structure of the slate belt proper is difficult to make out. The quartzite of the southeast side was not found on the northwest side during the reconnaissance. At the Foulk Jones \& Sons' Slate Hill quarry, 2 miles northeast of Delta, there are some indications of anticlinal structure. Apparent bedding planes dip $30^{\circ}$ to $40^{\circ} \mathrm{SE}$. on the southeast side of the quarry and similar planes curve over steeply to the northwest on the northwest side, both crossing the cleavage, which is nearly vertical. Whether this is a minor anticline in a complex syncline or anticline or the anticlinal axis of the entire belt could not be determined. There is also danger of confounding curver joints and bedding. Frazer's section along the right bank of the Susquehanna in York County (sheet 4, Vol. CCC) represents the slate as interbedded with chlorite schist and forming part of the northwest limb of a syncline several miles wide.

The Delta and Cardiff quarries. - In June, 1904, eleven concerns were operating quarries in the Peach Bottom belt. Five of these quarries or sets of quarries are located in Pennsylvania and six in Maryland. They lie in three parallel northeast-southwest lines and range from 75 to 120 feet across the cleavage and up to 200 feet in depth. The structural relations of these three belts of commercial slate are not yet apparent. The cleavage is uniformly vertical or dips steeply southeast with a strike ranging from N. $37^{\circ}$ to $55^{\circ} \mathrm{E}$. There is usually a horizontal joint-_" big flat joint"-pitching gently south, sometimes from 40 to 60 feet below the surface and including 2 to 3 feet of crushed slate, which is evidently the result of a secondary crustal movement. Commercial slate occurs only below this joint. The "top" varies from 6 to 65 feet and in places includes 10 feet of slate in small fragments. Other flat joints dip about $20^{\circ}$ NE. or $25^{\circ} \mathrm{SW}$. Longitudinal joints strike N. $48^{\circ}$ E. and dip $90^{\circ}$. Diagonal ones strike $\mathrm{N} .25^{\circ}-30^{\circ} \mathrm{W}$. and also $\mathrm{N}$. $45^{\circ} \mathrm{W}$., dipping northeast at angles ranging from $45^{\circ}$ to $90^{\circ}$ or $50^{\circ}$ to $80^{\circ}$. Conspicuous dip joints strike about at right angles to the cleavage and dip $90^{\circ}$ or southwest at angles of $25^{\circ}$ or $45^{\circ}$. At Foulk Jones \& Sons' there are vertical diagonal joints striking N. $10^{\circ}$ E. to N. $10^{\circ} \mathrm{W}$. The grain dips northeast from $20^{\circ}$ to $50^{\circ}$. Quartz veins meander in the cleavage direction. 'The slate is apt to have along the joint planes toward the surface a brownish rim, called a hem, from 1 to 2 inches wide and more or less parallel to the joint face. The slate breaks off at the inner side of the "hem," and this part is discarded. Some of the joints are parted and contain red clay a half inch or an inch thick. The hems represent simply the initial stage of weathering caused by the percolation of water from the joints, of which process the final result is the red clay. The slate of the top has generally a reddish hematitic hue, and the whole belt is covered with reddish clay. The chemical processes involved in the passage of Peach Bottom slate into red clay as determined by Doctor Merrill are given on page 37. The effect of weathering, as shown under the microscope, will be given after the microscopic analyses of the slate.

The quarrymen complain of the occurrence of what they call "black stuff," a hard material up to an inch thick, occurring sometimes in vertical planes diagonal to the cleavage. This proves to be an aggregate of much pyrite, carbonaceous matter, quartz, chlorite, and muscovite, and is probably vein matter segregated from the adjacent slate.

Peach Bottom slate.-This is very dark gray with a slightly bluish tinge. To the unaided eye it has a minutely granular crystalline texture, and a slightly roughish but quite lustrous cleavage surface. It is markedly graphitic and contains magnetite. The sawn edges show a little pyrite. There is no effervescence in cold dilute hydrochloric acid. It is very sonorous and does not discolor. $b$ Under the microscope it

a See also Frazer, as above, pp. 133,134.

$b$ The apparent contradiction of this last statement with the passage of this slate into red clay in weathering is explained on p. 37 . 
shows a matrix of muscovite (sericite), of rather coarse almost schistose texture, but with brilliant aggregate polarization. There is much graphitic material in fine particles and also much quartz, some of which is probably secondary, in grains measuring up to 0.05 and sometimes 0.12 by $0.03 \mathrm{~mm}$. Chlorite can in some specimens be made out mingled with the muscovite. There are tabular crystals of magnetite measuring up to 0.11 by $0.02 \mathrm{~mm}$., and also lenses of magnetite of larger size, but the most conspicuous feature is the abundance of crystals of andalusite $\left(\mathrm{Al}_{2} \mathrm{O}_{3}, \mathrm{SiO}_{2}\right.$, silicate of alumina) measuring from 0.008 by $0.001 \mathrm{~mm}$. and under, up to 0.11 by $0.03 \mathrm{~mm}$. and exceptionally 0.2 by $0.02 \mathrm{~mm}$., and numbering from 15 to 80 per square $\mathrm{mm}$. These crystals contain opaque inclusions arranged diagonally to their vertical axes, and are often in lenses, measuring from 0.04 to $0.25 \mathrm{~mm}$. long by 0.04 to $0.1 \mathrm{~mm}$. wide, which consist variously of chlorite interleaved with muscovite with some quartz at the ends, or mainly of quartz, the andalusite crystal having a plate of muscovite parallel to it on one or both sides; or the lens consists of muscovite, the crystal being bordered by quartz, or, finally, entirely of secondary muscovite. When not in lenses, the andalusites are apt to have a plate of muscovite on one or both sides. These crys-

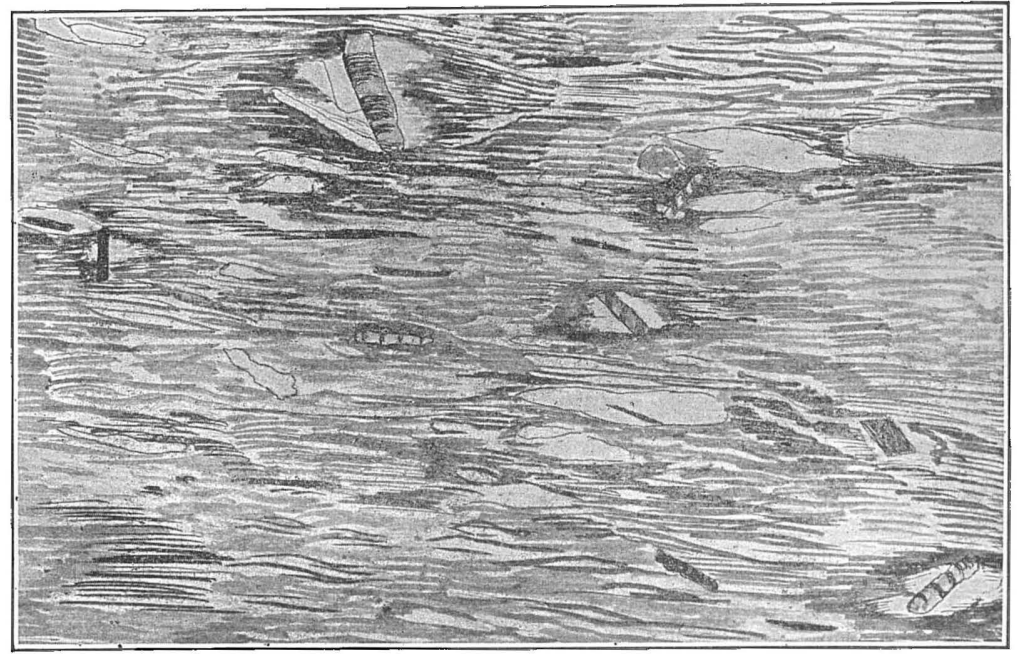

Fig. 10.-Transverse section of Peach Bottom roofing slate, showing andalusite crystals in a rather coarse micaceous matrix. Enlargement about 113 diameters. Some of these crystals are in lenses of quartz anđ̄ muscovite and several show inclusions.

tals lie with their long axes across the cleavage at various angles and with or across the grain, but the axes of the lenses which inclose them are usually parallel to the cleavage (see fig. 10). Pyrite is difficult to distinguish under incident light from the andalusite when this is rendered opaque by inclusions. Rutile occurs in irregular crystalline masses up to 0.09 by $0.04 \mathrm{~mm}$., but no needles were detected. There is rarely a rounded grain of zircon; no carbonate detected.

The important constituents of this slate, irranged in descending orler of abundance, appear to be muscovite (sericite), quartz, graphite, andalusite, magnetite, pyrite, with accessory rutile and zircon. Fig. 10 will serve to show the andalusite crystals which are so characteristic of this slate. The highly crystalline character of the matrix and the absence of carbonate indicate a very durable slate.

The partially weathered slate of the "top" and "hems" shows, under the microscope, the magnetite crystals and lenses passing into hematite and the andalusite becoming limonitic from the oxidation of its inclusions, which must, therefore, be ferruginous and the matrix stained with bematite and limonite from the above alterations. 
Peach Bottom slate has been thoroughly tested by Professor Merriman, $a$ with results as follows:

Modulus of rupture in pounds per square inch, 11.260; ultimate deflection in inches on supports 22 inches apart, 0.293; specific gravity, 2.894; softness (grains abraded by 50 turns of a small grindstone), 0.90; porosity (per cent of water absorbed in twenty-four hours), 0.224; corrodibility (per cent of weight lost in sixtythree hours in acid solution, consisting of 98 per cent $\mathrm{H}_{2} \mathrm{O}, 1$ per cent $\mathrm{HCl}, 1$ per cent $\left.\mathrm{SO}_{3}\right), 0.226$.

The three published analyses show the following percentages of lime: $0.155, \dot{b} 0.3, c$ 0.48. $d$ That by the second State Survey will be found in full on page 34. (Anal. VII.) This lime may be referable to the phosphate apatite, which the analyses show to be present.

Peach Bottom slates are now used exclusively for roofing purposes. The chief features of this slate are stated in tabular form in the section on the comparative characteristics of slates (p. 124).

\section{TENNESSEE.}

\section{By Edwin C. Eckel.}

Slate deposits occur in eastern Tennessee, notably southeast of Knoxville. The deposits here are described by Mr. Keith, $e$ as follows:

Two formations in this region contain beds of slate-the Wilhite and Pigeon slates. The Wilhite slate is too calcareous and soft for commercial use in the vicinity of Little Tennessee River, but has the necessary hardness, evenness, and cleavage along Little Pigeon River. Along this stream the slate is well exposed over great areas, but has never been developed. Quarries have been opened in the Pigeon slate along the Little Tennessee River at many points, and slates and flags taken out for local use. Recently a quarry has been opened on a small creek 2 miles from the river and much good material taken out for shipment. The slates are of fine, even grain, and split into slabs an inch thick, of any desirable size, or into roofing slates. In this particular quarry the cleavage crosses the bedding and produces ribbons in much of the slate. An old quarry about 2 miles north of this shows the cleavage and bedding coincident, and flags of griat size are readily loosened. Some of the slate layers contain pyrite, necessitating selection of the material for use. There are a great number of available places for quarrying in the bluffs along the river and the adjacent small streams on either side. That this slate resists weathering is amply proved by the high, sharp slate cliffs that border the river along most of its course.

The following analyses of slate quarried by the Southern Slate Company at Maryville, Blount County, were made by Mr. Gilbert McCulloch, of the University of Tennessee.

Analyses of Tennessee roofing slate.

\begin{tabular}{|c|c|c|c|c|c|}
\hline & 1. & 2. & & 1. & 2. \\
\hline Silica $\left(\mathrm{SiO}_{2}\right) \ldots \ldots \ldots \ldots \ldots \ldots$ & 58.45 & 59.00 & Potash $\left(\mathrm{K}_{2} \mathrm{O}\right) \ldots \ldots \ldots$ & 1.60 & 2.04 \\
\hline Alumina $\left(\mathrm{Al}_{2} \mathrm{O}_{3}\right) \ldots \ldots \ldots \ldots$ & 21.88 & 23.44 & Soda $\left(\mathrm{Na}_{2} \mathrm{O}\right) \ldots \ldots \ldots \ldots \ldots$ & 2.34 & 1.78 \\
\hline Iron oxide $\left(\mathrm{Fe}_{2} \mathrm{O}_{3}\right) \ldots \ldots$ & 6.04 & 6.28 & Sulphur trioxide $\left(\mathrm{SO}_{3}\right) \ldots \ldots$. & .65 & .23 \\
\hline Lime $(\mathrm{CaO}) \ldots \ldots \ldots \ldots \ldots . . . . . .$. & 1.86 & 1.30 & Water............................. & 6.66 & 4.64 \\
\hline Magnesia $(\mathrm{MgO}) . . . \ldots \ldots \ldots$. & .46 & .50 & $\cdot$ & & \\
\hline
\end{tabular}

$a$ Op. cit.

$b$ Second Pennsylvania Geol. Survey Rept. Progress for 1877, Vol. CCC, 1880; Anal. by A. S. McCreath, pp. $269,270$.

$c$ Anal. by Booth, Garrett, and Blair, 1885; see Md. Geol. Survey, vol. 2, 1898, p. 226.

d Merrill, G. P., Rocks, rock weathering, and soils, 1897, p. 229.

$e$ Keith, Arthur, Knoxville folio: Geologic Atlas U. S., folio 16 J. $s$. Geol. Survey, 1895, p. 6. 



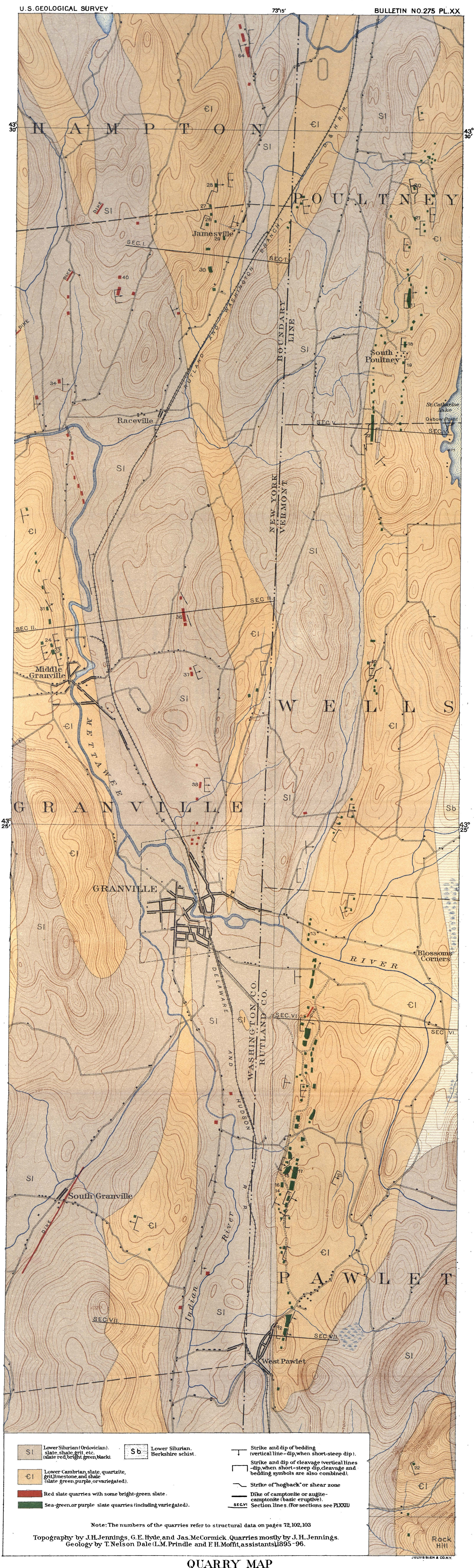

QUARRY MAP
SHOWING THE SITUATION AND SIZE OF THE SEA-GREEN, PURPLE, AND RED SLATE QUARRIES IN THE TOWNS OF HAMPTON AND GRANVILLE, NEW YORK, AND
POULTNEY AND PAWLET, VERMONT WITH THE GEOLOG OF THE VICINITY 


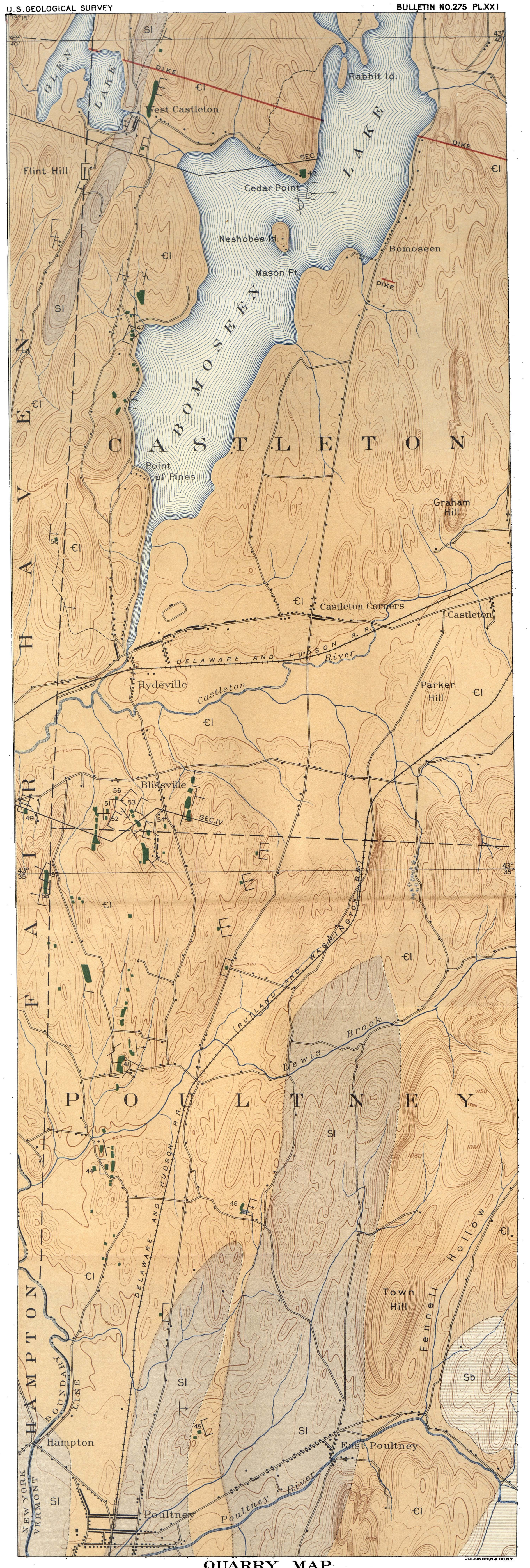

QUARRY MAP

SHOWING THE SITUATION AND SIZE OF THE MORE IMPORTANT SLATE QUARRES IN THE UNFADING GREEN SLATTE BELT BETWEEN SHOLLTNEY AND WEST CASTLETON, VERMONT, TOGETTER WTH A FEW OF TEE" SEA GREEN" SLATE QUARRIES NEAR POULTTEY.

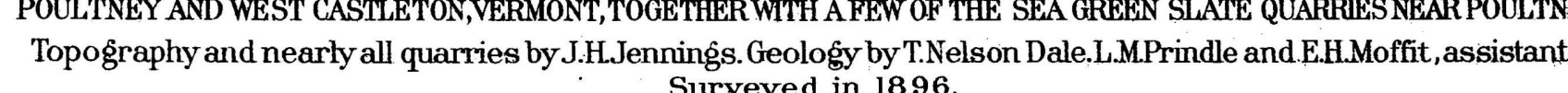
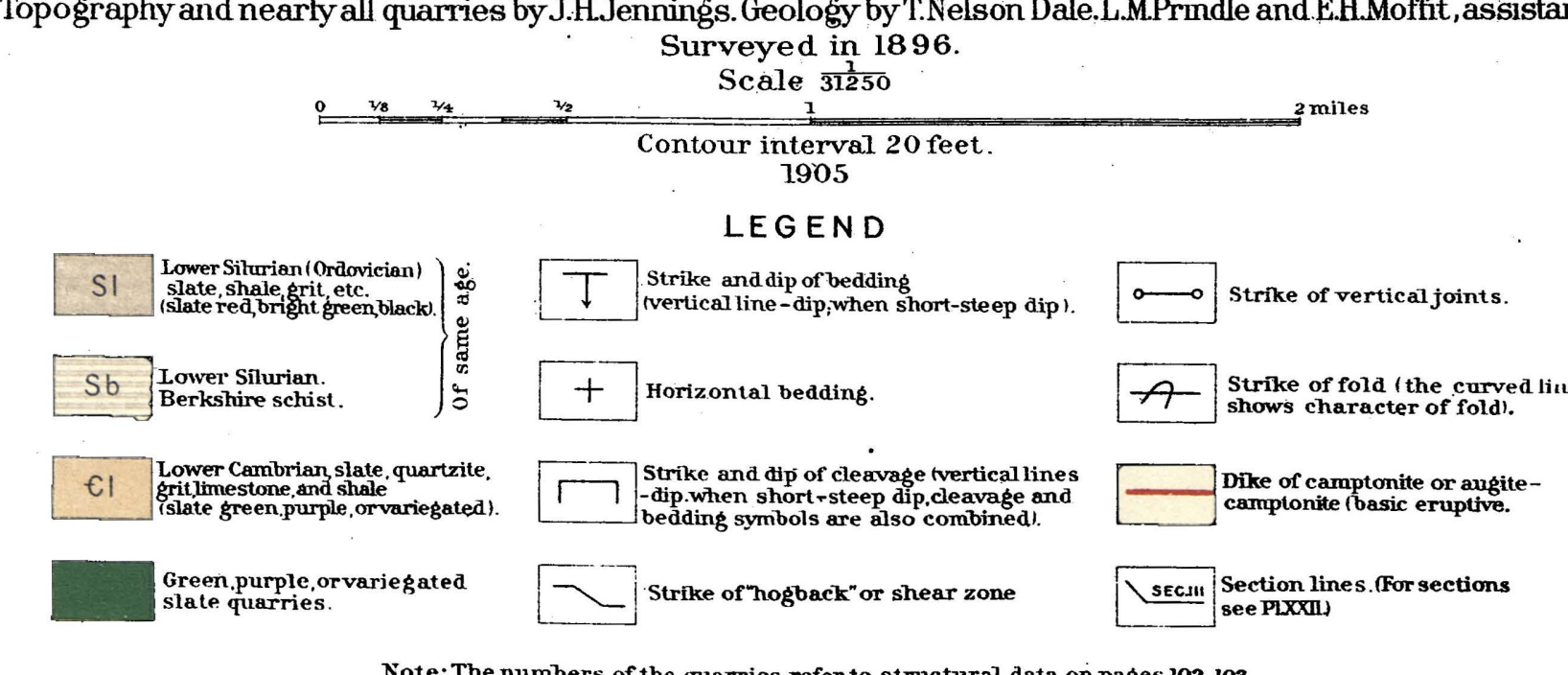

Note: The numbers of the quarries refer to structural data on pages 102, 103 



\title{
UTAH.
}

\author{
By Edwin C. Ecker.
}

For some years past a small amount of slate has been annually gotten out, chiefly for samples and trial shipments, at various points in Utah. Deposits of slate, believed to be of workable extent and of good quality, have been described as occurring on the islands in Great Salt Lake, and some attempt has been made to develop these deposits.

The locality which has been most widely discussed, however, is that near Provo. This has been exploited to some extent by F. W. C. Hathenbuck, of Provo. The slate deposits occur about 2 miles southeast of Provo station, in Slate Canyon. The slate here covers a considerable area, but that exposed at the surface is so badly broken up that large slabs can not be obtained. It is possible, however, that this condition will disappear if the deposits are worked deeper.

The Provo deposits furnish green and purple slates, the latter being apparently present in greater quantity. The green slates show little tendency to cleavage in their surface outcrops, and will probably be less satisfactory for roofing purposes than the purple. The green slates rub very smooth, however, and would make good slabs or mill stock if obtainable in masses of sufficient size.

The purple slates split well, with a surface about as smooth as that of Peach Bottom (Pennsylvania-Maryland) slate. From samples seen it appears that they also bear punching well.

A specimen of the purple slate selected by the writer was analyzed by Mr. W. T. Schaller in the laboratory of the United States Geological Survey, the results being as follows:

$$
\text { Analysis of purple slate, Provo, Utah. }
$$

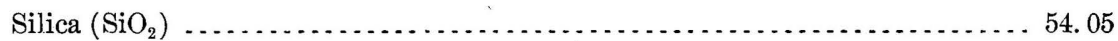

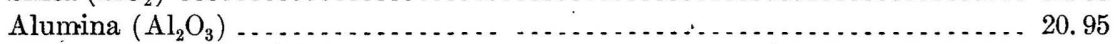

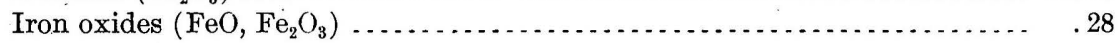

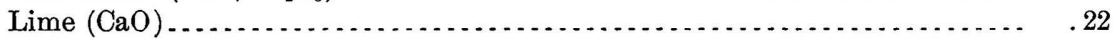

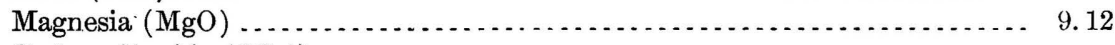

$\left.\begin{array}{l}\text { Carbon dioxide }\left(\mathrm{CO}_{2}\right) \\ \text { Water } \ldots \ldots \ldots \ldots \ldots \ldots \ldots \ldots \ldots \ldots \ldots \ldots \ldots \ldots \ldots \ldots \ldots \ldots \ldots \ldots \ldots \ldots \ldots \ldots\end{array}\right\}$

Of a series of 36 analyses of American roofing slates collected and discussed $a$ recently by the writer, the above slate from Provo stands lowest in its percentages of silica and magnesia, while its lime is very far below the average.

Nothing definite is known as to the geologic age of these slates, though they are supposed to be Ordovician, or even older.

\section{VERMONT.}

By T. Nelson Dale.

\section{GEOGRAPHICAL RELATIONS.}

There are at least four distinct slate districts in Vermont. The most easterly extends along the Connecticut River for more than two-thirds the length of the State. The slate is black or dark gray, and has been worked in Guilford, in Windham County, at the extreme southern end of the State, and also in Thetford, in Orange County, and at Waterford, in Caledonia County. The next extends along the east flank of the Green Mountain range from the Canada line to about the middle of the 
State, and has been extensively worked at Northfield, in Washington County. The most important district, which furnishes the well known "green" and "purple" slates, lies between the Taconic range and Lake Champlain, extending from the town of Sudbury, in Rutland County, southward to Rupert, in Bennington County, a distance of 26 miles. This belt also passes south-southwest into Washington County, N. Y., where, however, it has thus far proved of less economic importance. The fourth is black slate, as yet undeveloped, and covering only from 10 to 12 square miles in the town of Benson, in Rutland County, near Lake Champlain.

\section{NORTHFIELD.}

Geological relations. - The Vermont geological map $a$ represents a belt of clay slate, from 1 to 7 miles wide, as extending from Lake Memphremagog along the east side of the Green Mountain axis as far south as Barnard, in Windsor County, a distance of 90 miles. A recent paper and map by Richardson $b$ represents a portion of this slate belt 52 miles long, extending from North Calais, in Washington County, to a point in Windsor County nearly 10 miles west of White River Junction. The age of this slate formation was thought to be probably Devonian by the authors of the older report, $c$ but Richardson regards it as Lower Trenton. Conclusive paleontological evidence on the subject is yet lacking.

This slate has been quarried at Montpelier and Northfield, which are 10 miles apart. The strike of bedding at both places ranges from N. $10^{\circ}$ to $20^{\circ} \mathrm{E}$. At the Vermont Black Slate Company's quarry, 2 miles south of Northfield, the beds occur in minor very acute folds, as shown in fig. 11 which strike N. $10^{\circ}$ E., while the cleavage, with an almost identical strike, dips W. at $75^{\circ}$. This indicates that the general course of the bedding is not far from horizontal and that lateral repetitions of strata are to be looked for. The interpretation given by Richardson of $\mathrm{Pl}$. XV in his paper, referred to above, requires corroborative microscopic evidence. The low easterly (by error printed west) dipping planes resemble a secondary cleavage, while the steep westerly ones have the characteristics of bedding.

The slate continues about 300 feet west of this quarry, and about a third of a mile east, making its total width in that vicinity about 2,000 feet. The general relations of this slate on the west are these: The western part contains a bed of novaculite up to 12 feet thick, and is followed by slate of no commercial value, which is followed at the foot of the range, about three-fourths mile southwest of the village, by a sericite-chlorite-quartz-schist with grains of plagioclase, with a vertical slip cleavage striking about north and a plicated bedding with a northerly pitch. After a covered interval, at a point on the range 2 miles west of the village, there is a large exposure of thin-bedded, more or less muscovitic quartzite (with grains of zircon and plagioclase), so intricately folded as to strike N. $20^{\circ}$ E., N. $20^{\circ}$ W., N. $50^{\circ}$ E., and N. $90^{\circ}$ E. An area of a few acres of muscovite granite (formerly quarried, Moses King property) lies within this quartzite, or at least with this quartzite on both its east and west sides. This granite in places becomes orbicular, carrying nodules of concentrically arranged mica an inch in diameter. $d$

Northfield slate.-In 1904 but one quarry was in operation at Northfield, that of the Vermont Black Slate Company, which measures about 100 feet along the strike, 60 feet across it, and 55 feet in depth. The relations of cleavage and bedding are shown in fig. 11. The cleavage strikes N. $12^{\circ}$ E. and dips $75^{\circ} \mathrm{W}$. Strike joints strike N. $15^{\circ}$ E., dip $50^{\circ}$ W., dip joints N. $77^{\circ}$ W., and dip $85^{\circ} \mathrm{S}$. Diagonal joints strike N. $55^{\circ} \mathrm{E}$. and $\operatorname{dip} 65^{\circ} \mathrm{NW}$. The grain dips $70^{\circ} \mathrm{N}$. An exceptional false cleavage dips $15^{\circ}-20^{\circ} \mathrm{N}$. As there are no ribbons in the bedding nor horizontal joints cross-

a Hitchcock and Hager Rept. Geol. Vermont, vol. 2, 1861, Pl. I, p. 794.

$b$ Richardson, C. H., The terranes of Orange County, Vt., Slate, p. 77-79, and map, Pls, IX, IX $A$, in Rept. State Geologist Vermont, (3) of new series, 1901-1902.

$c$ Vol. 1, p. 497.

d Rept. Geol. Vermont, vol. 2, pp. 563, 564 . 


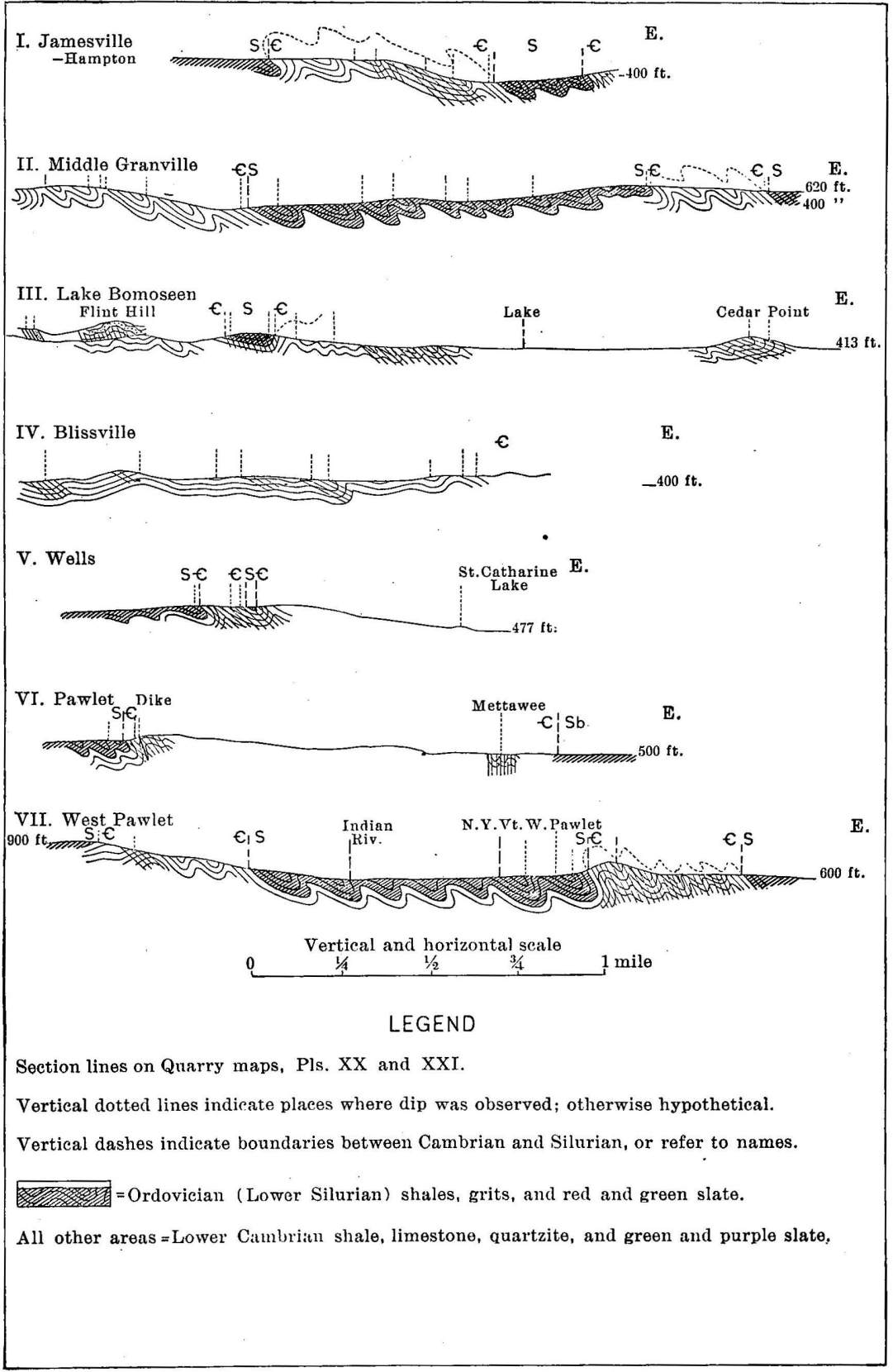



ing the cleavage, channeling in a horizontal direction becomes necessary. It is, therefore, easier to obtain very large slabs for mill stock than small ones for roofing slates.

The slate is very dark gray; to the unaided eye has a very fine texture. The cleavage surface is very smooth and very lustrous, but has here and there minute longish crystals of pyrite pointing in the direction of the grain, also some very minute nonmetallic lenses. It appears to be slightly graphitic and contains a very little unagnetite. The sawn edge shows lenses and crystals of pyrite from 1 to $3 \mathrm{~mm}$. long. There is no effervescence in cold dilute hydrochloric acid. It is very sonorous, very fissile, and does not discolor.

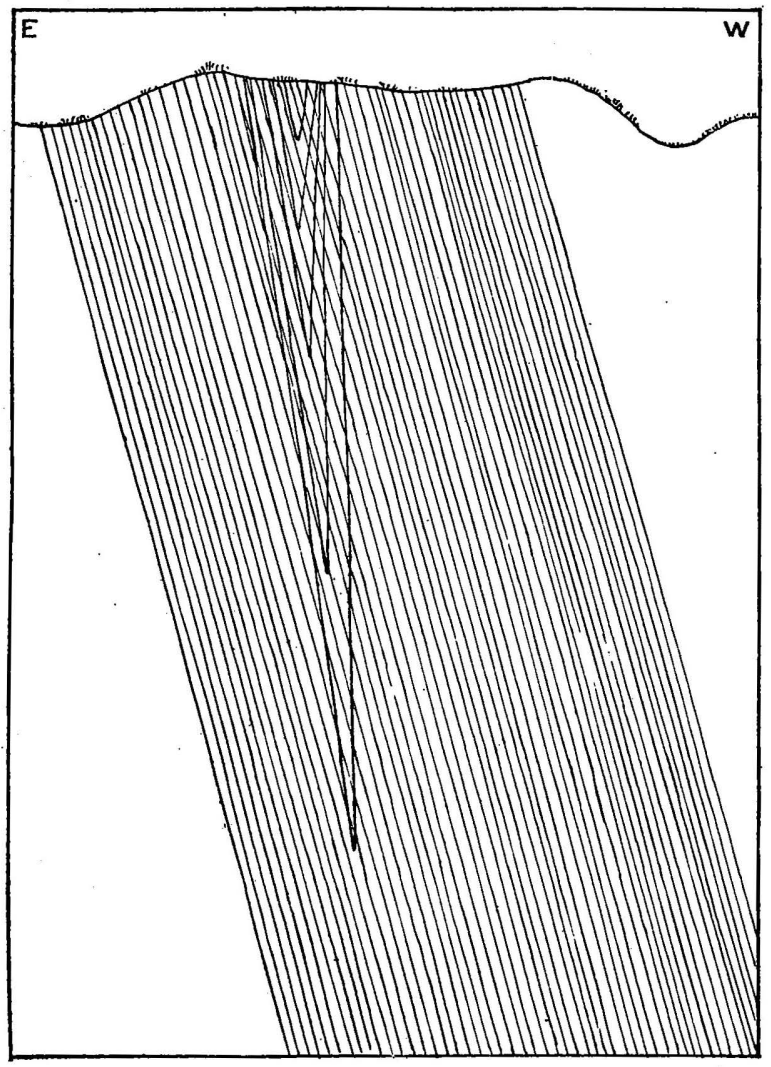

FIG. 11.-Syncline at Vermont Black Slate Company's quarry, near Northfield, Vt.; looking S. $12^{\circ} \mathrm{W}$. Depth of syncline as figured, 44 feet.

Under the microscope shows a matrix ${ }^{a}$ of muscovite (sericite), with a very brilliant aggregate polarization and a very even texture. There are abundant quartz fragments up to $0.06 \mathrm{~mm}$., exceptionally 0.1 by $0.03 \mathrm{~mm}$. The lenses and crystals of pyrite (including a small percentage of magnetite) number from 7 to 8 per square millimeter and measure from 0.05 by 0.03 up to 0.06 by $0.1 \mathrm{~mm}$. These figures, however, do not include the exceptionally large ones, visible without a glass. The long axes of these lenses and crystals lie in the cleavage but parallel to the grain. They are usually surrounded by a rim of secondary quartz and muscovite, sometimes also of chlorite, radiating from the nucleus a distance of 0.04 to $0.08 \mathrm{~mm}$. In some cases 


\section{PLATE XXIII.}

\section{STRUCTURAI, DIAGRAMS OF SLATE QUARRIES IN EASTERN NEW YORK AND WESTERN VERMONT.}

(A) Rising \& Nelson's "sea-green" quarry No. 2, West Pawlet, Vermont.

(B) Rising \& Nelson's " sea-green" quarry No. 2, West Pawlet, Vermont, with measurements.

(C) Hughes's "sea-green" quarry No. 7, West Pawlet, Vermont.

$(D)$ Robert R. Roberts's "sea-green" quarry, Pawlet, Vermont.

(E) Hughes's western quarry "sea-green," Pawlet, Vermont.

(F) McCarty's "sea-green" and purple quarry, Poultney, Vermont.

$(G)$ Schmidt \& Williams's "sea-green" quarry, Pawlet, Vermont.

$(H)$ Empire slate quarry (red), Granville, New York.

( $I)$ Auld \& Conger's quarry ("sea-green" and variegated), Wells, Vermont.

$(K)$ Griffith \& Nathaniel's quarry ("sea-green" and purple), Poultney, Vermont. 92 
U. S. GEOLOGICAL SURVEY

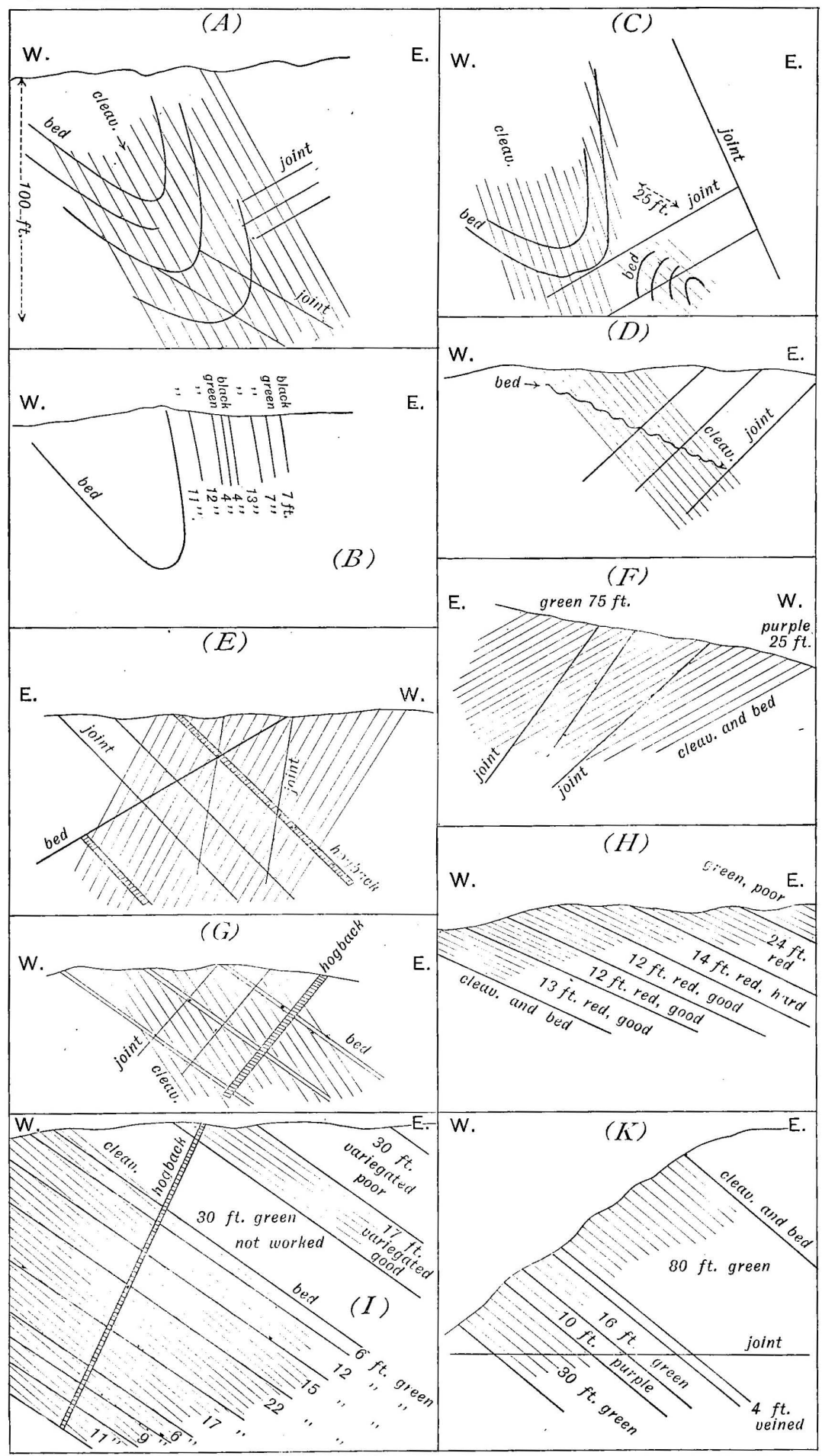

QUARRY DIAGRAMS, NEW YORK AND VERMONT SLATE BELT. 

these secondary minerals radiate only in the zone of the cleavage of the slate. There are a few lenses of interleaved muscovite and chlorite. Considerable dark-gray, probably graphitic, matter in extremely fine particles, very little carbonate, prisms of rutile up to 0.04 by $0.006 \mathrm{~mm}$. and more rarely irregular angular masses of the same mineral, and finally some crystals of toumaline, 0.36 by $0.008 \mathrm{~mm}$. The nonmetallic lenses referred to above are evidently the quart\%-coated pyrite lenses.

The chief constituents of this slate, arranged in descending order of abundance, appear to be muscovite (sericite), (unart», pyrite, graphite, magnetite, chlorite, carbonate, besides accessory rutile and tourmaline.

For the reason given the product of this quarry is destined almost entirely for mill stock, but the examination shows it to be a superior roofing slate.

The following data were gathered at the abandoned quarry of the Union Slate Company a half mile east-southeast of Northfield: Bedding strike, N. $10^{\circ}$ E., dip $80^{\circ}$ $\mathrm{W}$; cleavage strike, N. $4^{\circ}$. E., dip $70^{\circ} \mathrm{W}$. Strike joints dip, undulating, low west; diagonal ones strike $\mathrm{N} .60^{\circ}-65^{\circ} \mathrm{W}$. and dip $75^{\circ} \mathrm{NE}$.

\section{MONTPELIER.}

At the abandoned quarry three-fourths mile southeast of Montpelier and about 10 miles north-northeast of the Vermont Black Slate Company's quarry at Northfield the strike of both bedding and cleavage was found to be N. $15^{\circ}-20^{\circ} \mathrm{E}$., dip $70^{\circ}-75^{\circ}$ W. This quarry was operated by means of three wide openings at intervals across the strike and communicating with each other by a 10 -foot open cut, which also served as a drain. The quarry is said to have been abandoned on account of the large percentage of waste, which may have been the result of the complex opening. The slate appears to be essentially the same as that of the Northfield quarries.

\section{WESTERN VERMONT.}

Geological relutions.-The broader geographical and geological relations of the western Vermont slate belt are shown in the map of the slate belt of castern New York and western Vermont, $c$ and still more fully in the economic and structure section sheets of the forthcoming Mettawee and Fort Ticonderoga folios.

The Ordovician (Hudson) schist of the Taconic range is bordered on the west, except along a stretch of 6 miles in Pawlet and Rupert, by a belt of Lower Cambrian rocks estimated as at least 1,400 feet in thickness, which include about 240 feet of greenish and purplish roofing slates. This boundary between the Ordovician and Lower Cambrian has recently been shown to represent not only an unconformity but a folded overlap. $b$ In Pawlet and Rupert the schists of the Taconic range merge at the west through decrease of metamorphism into an irregular area of shales and grits of the same (Hudson) age not less than 1,200 feet thick, which include about 50 feet of commercial reddish and greenish slate. These have long been quarried in Granville and Hampton, N. Y., and are described in detail on page 70 . In places the Lower Cambrian slate protrudes through the Ordovician slate areas; in others lenticular remnants of Ordovician slate overlie the Lower Cambrian slate. The relations of these two formations are more intricate in the New York part of the slate belt than in the Vermont part. In Pls. XX and XXI their relations in the vicinity of the chief quarrying centers are shown, as well as the location and form of nearly all the slate quarries. $c$

a The slates of western Vermont were fully described by the writer in part 3 of Nineteenth Ann. Rept. U. S. Geol. Survey in 1899, and the matter appears here in revised form, but the general map, Pl. XIII, is not republished.

$\checkmark$ See Am. Jour. Sci., 4th ser., vol. 17, 1904, p. 185.

$c$ It will be noticed that Pl. XXI fits onto the eastern half of the northern end of Pl. XX. The scale of these maps is so large that they can be used for prospecting purposes by studying the relations of the quarry locations to the symbols which designate the strike of the beds: See also p. 44 . 
The Lower Cambrian slates of western Vermont are greenish gray, purplish, and "variegated," i. e., greenish gray and purplish mixed. These occur in alternations. The quarry diagrams (Pls. XXIII and XXIV) show that there is little regularity in these alternations. In the main, however, this horizon seems to consist of from 100 to 140 feet or even 200 feet of greenish and purplish slates, the greenish ones predominating, with from 40 to 50 feet of variegated or mottled overlying, but possibly replacing the purple in places. On the west side of Lake Bomoseen nearly 100 feet of purple are exposed. The purple sometimes contains a few inches of dark-redish slate not unlike the red of the Ordovician. There is some difference in the shade of the different beds of green in the same quarry, some being more greenish, others more grayish. There are also differences in the amount of discoloration produced by weathering in beds of the same locality. Although some quarries produce only the so-called "unfading green" and others only the "sea green," these differences appear not to belong to strata of different ages, but to sccur at different points in strata of the same age.

Interbedded with the slates are beds of calcareous quartzite of very different areas, ranging in thickness from a few inches up to 5 feet. This quartzite contains a few grains of plagioclase and more muscovite scales, and is veined with quartz, which crystallizes in cavities. The quartzite sometimes weathers brown; its calcite, therefore, probably contains some siderite.

Associated with the slates are also beds of limestone conglomerate or breccia ranging from a few feet to 40 feet in thickness, carrying the trilobite Olenellus and other fossils characteristic of the Lower Cambrian. One of these beds of limestone breccia is of frequent occurrence in the quarries, overlying the slate. (See quarry diagram $P$, Pl. XXIV.)

The slate-bed surfaces are generally covered with annelid trails or impressions of algæ, or both. The purple slates are often ribboned or banded with light-green slate beds an inch or more in thickness, or have oval or roundish light-green spots, frequently in rows. Similarly the "sea-green" slates have grayish ribbons crossing them.

The position of these commercial slates in the Lower Cambrian series is shown in the following table, in which the beds are arranged in their natural order:

Lower Cambrian rocks of slate belt of western Vermont.

(E) Ferruginous quartzite and sandstone .............................. $25-100$

(D) Black shale and slate with Lower Cambrian fossils.............. 50-250

(C) Black patch grit; a dark-gray grit or sandstone with black shaly patches, sometimes with calcareous nodules carrying Lower Cam-

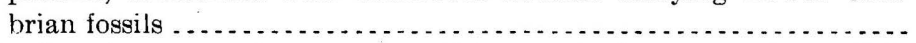

(B) Roofing slate, grayish green, purplish or mixed green and purplish, alternating with beds of calcareous quartzite and limestone breccia up to 40 feet thick, the latter carrying Lower Cambrian fossils ...... 200-240

(A) Olive grit or graywacke, more or less massive, with minute scales of hematite or graphite, sometimes with small quartzite beds, frequently calcareous, generally weathering a pale brick red. Under the microscope shows grains of quartz, feldspar, large scales of muscovite and of chlorite interleaved with muscovite. Associated with this is a bed of quartzite $12-55$ feet thick . . . . . . . . . . . . . . . . . . . . . . . . . . . .

The base of the formation is not certainly exposed. There may be a bed of commercial slate in the olive grit.

The probable structure and structural relations of the two slate formations of western Vermont are shown in Pl. XXII. Each section is described beyond in detail. Those parts of the sections which are well snbstantiated are indicated by 
vertically dotted lines. The typical features of the region are finely shown at certain points, and these have been utilized in drawing the hypothetical parts of the sections. Symbols showing the structure at a number of the quarries are given on the large-scale quarry maps (Pls. $\mathrm{XX}$ and $\mathrm{XXI}$ ), upon which the section lines have been drawn.

\section{GEOLOGICAL SECTIONS.}

SECTION I.-JAMESVILLE-HAMPTON.

This crosses the Jamesville Cambrian slate belt. The occurrence of the Ordovician red slate on the east of the Jamesville belt is shown at the Matthews quarries, a mile west of Puultney, in Hampton, and on the west at those of the National Red Slate Company, about a mile north-northwest of Raceville, in the town of Granville. About a mile due north of Raceville there is a small opening in red slate in close proximity to the Cambrian. The red slate dips easterly under the Cambrian by overturn. From 500 to 600 feet north-northwest of this the Hudson grits crop out, and a mile north-north west, on the east side, three-fourths of a mile north of section, Mr. Walcott found Hudson graptolites in eastwardly dipping shales.

The eastern base of the Jamesville Ridge consists of the Cambrian black slates and shales with small beds of limestone (D). $a$ These also crop out at the bend in road south of section. These slates and shales form the uppermost strata of the ridge, (E) being absent, but that outcrop probably belongs to those on the west side of the ridge. Arising from beneath (D) are the green and purple roofing slates, with 10 feet of limestone carrying Lower Cambrian fossils. There are seven or eight old quarries on the hillside. In the largest 20 feet or more of black and gray slates overlie the green and purple slates, which dip $22^{\circ} \mathrm{E}$., with a cleavage of $35^{\circ} \mathrm{E}$. A low easterly bedding and a steeper easterly cleavage (up to $45^{\circ}$ ) are well shown at several quarries. Beds of calcareous quartzite occur. The purple slates now underlie, now overlie, the green. In the main the ridge appears to be an anticline of (B) and (D), very much overturned to the west, with the red slates and the Hudson graptolite shales and the Hudson grits on both sides of it. In the section the only well-observed things are the relations of cleavage and bedding on the eastern slope. The overturn at the west where the Ordovician underlies is inferential and the other folds are hypothetical.

SECTION II.-MIDDLE GRANVILLE.

This crosses the Middle Granville "sea-green" and red-slate quarries. Judging from the dovetailing of the Cambrian and Ordovician a few miles south of Middle Granville, we should expect, immediately west of Middle Granville, first, an anticline, then a syncline. The Jamesville belt crossed by the eastern end of the section would be, as in Section I, anticlinal, and the intervening broad Ordovician belt would be synclinal in structure.

There are about a dozen Cambrian slate quarries north of the village. Some measurements were taken about these quarries by the writer, but the locality is perplexing. There is a fault, and possibly much folding and faulting. The following succession, however, is clear, beginning above: Black shale and slaty shale (D), 70-100 feet; limestone with Lower Cambrian fossils, 4 feet; green and purple slate (B), 50-60 feet. There is an open drainage cut 213 feet long, east of one of the larger quarries, which crosses the black shales and exposes one fault plane. There is a tunnel 180 feet long west of the quarry, with a shaft at the end also in black shales. The men who worked in the tunnel report that it also traversed black shales. West of the shaft is another slate quarry, and southeast of the east end of the open cut still 


\section{PLATE XXIV}

STRUCTURAL DIAGRAMS OF SLATE QUARRIES IN EASTERN NEW YORK AND WESTERN VERMONT.

(L) Eureka slate quarries ("unfading green" an'd variegated), Poultney, Vermont.

$(M)$ Valley Slate Company ("unfading green"), Poultney, Vermont.

$(N)$ Lake Bomoseen Slate Company (mill stock, purple and green), Cedar Point, Castleton, Vermont.

(O) Old quarry (purple with green ribbons), near Blissville, Castleton, Vermont.

$(P)$ Old quarry near and north of Eagle Quarry, purple with green ribbons, Blissville, Castleton, Vermont.

(Q) Meadow Slate Company's quarry (mill stock, variegated and green), Fair Haven, Vermont. Calcareous quartzite beds 4 to 12 inches thick and 18 inches apart.

(R) Meadow Slate Company's quarry, Fair Haven, Vermont, at north end,

$(S)$ Scotch Hill Slate Quarry Company's quarry (mill stock, purple, variegated, and green), Fair Haven, Vermont. Dark beds are said to underlie the green.

(T) Old quarry (purple), 1 mile south of West Castleton, Vermont.

$(U)$ National Red Slate Company's quarry, southwest of Jamesville, in Granville, New York.

(V) Williams and Edwards's quarry ("sea-green"), Wells, Vermont.

96 
U. 8. GEOLOGICAL SURVEY

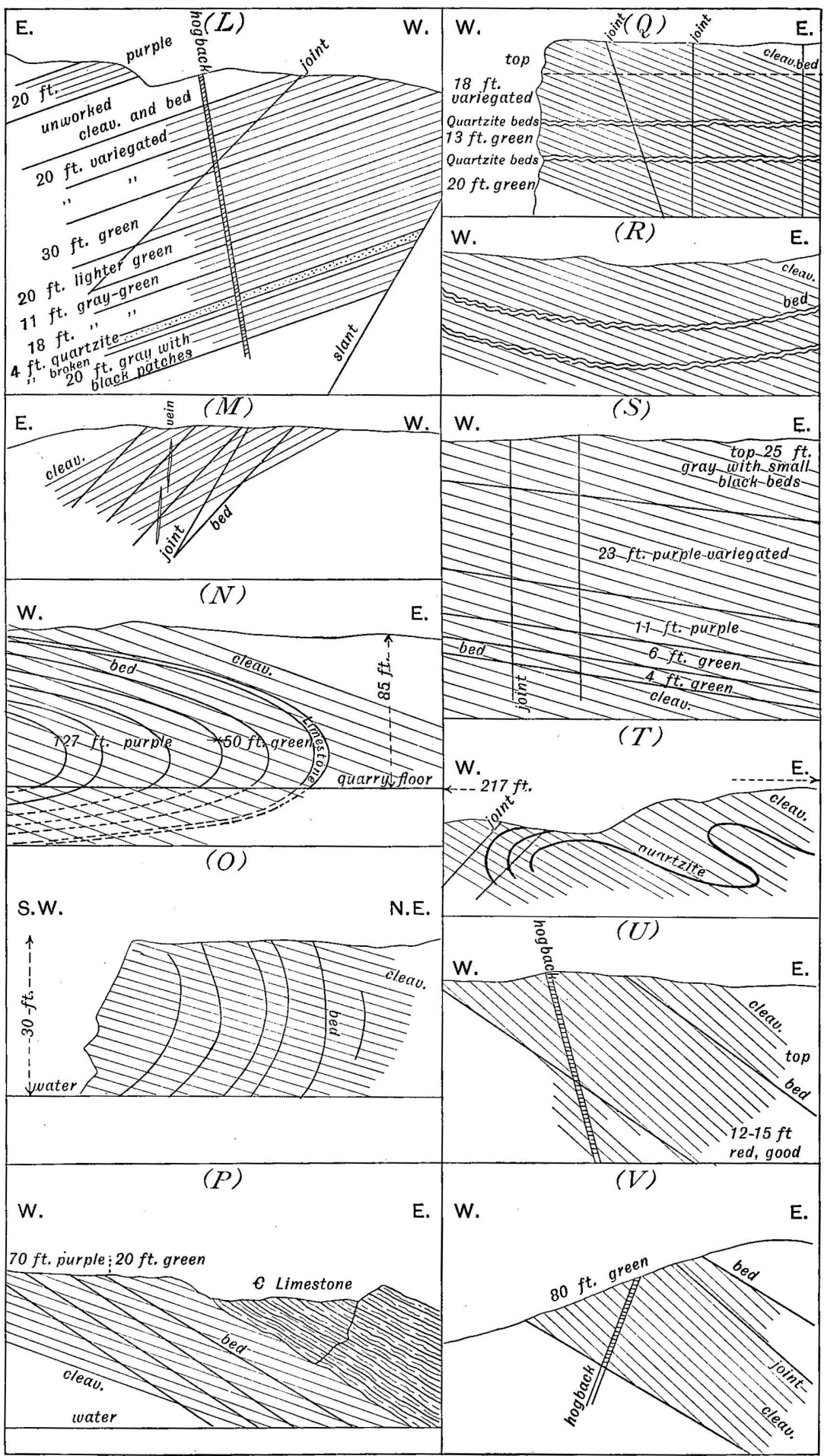

QUARRY DIAGRAMS, NEW YORK AND VERMONT SLATE BELT.

Bull. 275-06- 8 

another one. There appear, therefore, to be two masses of black beds and three of roofing slate. Mr. Prindle finds some evidence of an Ordovician area at the top of the hill. It would seem, therefore, possible that between that point and the red slate of the valley on the east we have an anticline consisting of several minor folds, and that the Cambrian green and purple slate occupy the centers of the lesser anticlines and the black shales the sides, as shown in the section. But the structure might be interpreted as consisting of two beds of green and purple slates alternating with two of black shale, or a fault could be supposed between the central body of green slate and the black slate west of it. Several quarries in this line show about 70 feet of the black rock $(\mathrm{D})$.

Only occasional observations were made in the valley east of the ridge, and these all indicate low easterly dips, and so do the observations at Nixon's and Pritchard's quarries, with slight indications of a westerly dip at one of the latter. The folds are probably all overturned to the west, but their dimensions may vary greatly from those shown in this part of the section. The only data as to the Cambrian ridge at the east end of the section are easterly dips on both its east and west sicles, indicating the usual overturn.

\section{SECTION III.-LAKE BOMOSEEN.}

This crosses Cedar Point and extends to Glen Lake. At Cedar Point, Lake Bomoseen Slate Company's quarry, there are 127 feet of purple, overlain by 50 of green, and these by 5 to 10 feet of limestone, but all doubled over into a close syncline with an axial plane almost, if not quite, horizontal and traversed by a cleavage foliation dipping $20^{\circ}$ east (see Pl. XXIV, $N$ ). For that part of the section which lies east of the Ordovician strip and west of the bend in the section line the data have been taken from the old quarries a mile south (see Pl. XXIV, fig. T, and Pl. XXII). The folds are many and small and overturned to the west. At the West Castleton quarries, north and south of this section and east of the Ordovician strip, the slates dip $45^{\circ}$ to $50^{\circ}$ east, and consist of about 25 feet of purple overlain by 8 feet of green slate, and these by 8 feet of limestone, followed by poor slates and quartzite beds. The relations of Ordovician and Cambrian are not well exposed. The Cambrian slates must either turn steeply to the west or be faulted. At the extreme north end of the Ordovician strip Mr. Prindle made out the following relations: The Black Cambrian slates (D) and the-Ferruginous quartzite (E) occur between the Cambrian limestone and roofing slates (B) and the Ordovician graptolite shales. About a half mile north of West Castleton the graptolite shales occur 300 feet west of the Cambrian slates with some thin quartzites.

The structure of the Ordovician strip itself is beautifully shown at a ledge by the roadside between West Castleton and Glen Lake (see Pl. III). The rock is a grayish, more or less calcareous shaly or arenaceous slate, banded with black beds from a fraction of an inch to 2 inches in width. On the west side of the syncline the beds dip very slightly east or are horizontal. Farther east, at the top, the dip is $55^{\circ}$ $\mathrm{W}$. and still farther $90^{\circ}$. The cleavage throughout is about $35^{\circ} \mathrm{E}$. The ledge is evidently the center of the syncline and gives the key to the structure of the whole strip, which is $3 \frac{1}{4}$ miles in length, while the fossils leave no doubt as to its age.

SECTION IV.-BLISSVILLE.

This crosses several lines of quarries near Blissville, in Castleton, Vt. There are 20 quarries hereabouts, including the old Eagle quarry. The northeasterly line of quarries shows a minimum of about 50 feet of green and variegated slate (strike N. $10^{\circ}$ to $15^{\circ} \mathrm{E}$., $\operatorname{dip} 20^{\circ}$ to $30^{\circ} \mathrm{E}$.) overlain by 20 feet of black slate and shale and thinbedded limestone, followed by a few feet of green slate and a bed of quartzite 10 to 12 feet thick, which is exposed for 350 feet along the strike. The quartzite contains calcareous nodules which weather out and overlies and, at the south, runs into a 
few feet of a green grit like that of Flint Hill. The black shales crop out at several points along the road south, and also on the ridge east of it. These are classed in (D) and the quartzite in (E) of the table.

Between this line of quarries and the road running south the Olive grits (A) crop out at several points and extend to the road corner north-all with an easterly dip. The first quarry on the west side of the north and south road shows a very gentle syncline at its south end and the beginning of an anticline at its northeast corner. The next line of quarries west includes the Eagle. The strike here changes to N. $15^{\circ}-$ $20^{\circ}-30^{\circ}-40^{\circ} \mathrm{W}$. The dips are $25^{\circ}-30^{\circ} \mathrm{E}$. and SE. The cleavage strikes N. $5^{\circ} \mathrm{E}$. and dips $20^{\circ} \mathrm{E}$. There are about 70 feet of purple, overlain by 10 feet of green and these by 15 feet of thin-bedded Olenellus limestone. At the most northerly quarry but one of this line the beds are folded and overturned almost as much as at Cedar Point (see fig. 0 , Pl. XXIV). The strike of axis of fold is N. $40^{\circ} \mathrm{W}$.; cleavage dip, low, east. Small beds of light green, with or without a quartzose limestone in the center, produce bands on the cleavage surface.

At a quarry intermediate between the second and third lines of quarries, and onefourth of a mile north of this section, the strike changes to N. $75^{\circ} \mathrm{W}$., dip $15^{\circ}-20^{\circ} \mathrm{S}$; cleavage strike, N. $35^{\circ}-50^{\circ} \mathrm{E}$., dip $15^{\circ} \mathrm{E}$. The complication is probably due to a southerly pitch.

In the third line of quarries the beds are nearly horizontal. The fourth line, a half mile south of section, shows very low westerly dips and at the extreme west end of the section a gentle syncline is exposed crossed by a cleavage dipping $35^{\circ} \mathrm{E}$.

$$
\text { SECTION V.-WELLS. }
$$

This starts at the west shore of Lake St. Catherine and crosses the slate ridge west. The portion of the slate belt most largely worked of late years is the ridge between West Pawlet and Poultney. Away from the quarries it is difficult to obtain satisfactory observations, and within the quarries bedding is generally obscured by cleavage.

Beginning at the lake, purple and green Cambrian slates dip $45^{\circ} \mathrm{F}$. Judging from scattering observations along the west side of the ridge, it must be largely composed of roofing slate. From a point about a half mile west of the lake there is a line of quarries and prospect holes extending northward for 2 miles. The cleavage dip is uniformly east. Farther west the section crosses a strip of red Ordovician slate almost a half a mile long and 180 feet wide at the broadest part, but tapering out both north and south. The dip is $35^{\circ} \mathrm{E}$. This is probably a small compressed and overturned syncline. The Ordovician grit is absent here, but some of the small quartzite beds occur between the Cambrian slates and the red slates. All the slates exposed between the strip of red and the road on the west should recur on the east of the red, but in inverse order. At Auld \& Conger's quarries there are 170 feet of slate of various qualities, green and variegated, exposed. Strike N. $5^{\circ} \mathrm{W}$., dip $35^{\circ} \mathrm{E}$., with cleavage dipping $40^{\circ}-45^{\circ} \mathrm{E}$. Dipping toward and under the slate, but with greenish and grayish beds intervening, are the Hudson grits. Strike N. $5^{\circ}$ E., dip $40^{\circ}$ E. Between the syncline of red slate and the Hudson grits there is probably an anticline, as drawn in the section, and all the slates on the west side of the red ought to recur east of the grits in inverse order. The folds shown in the grit are hypothetical, but the first one west of the slate would naturally be a syncline.

\section{SECTION VI.-PAWLET.}

This begins near the Mettawee and crosses the slate ridge. The boundary between Ordovician and Cambrian at the east end of the section is uncertain. In the gorge of the Mettawee green and purple Cambrian slates of no commercial value are finely exposed. At the sawmill the axial planes of the folds stand erect, and the anticlinal parts of some of the folds have been pinched out. The cleavage is vertical. The 


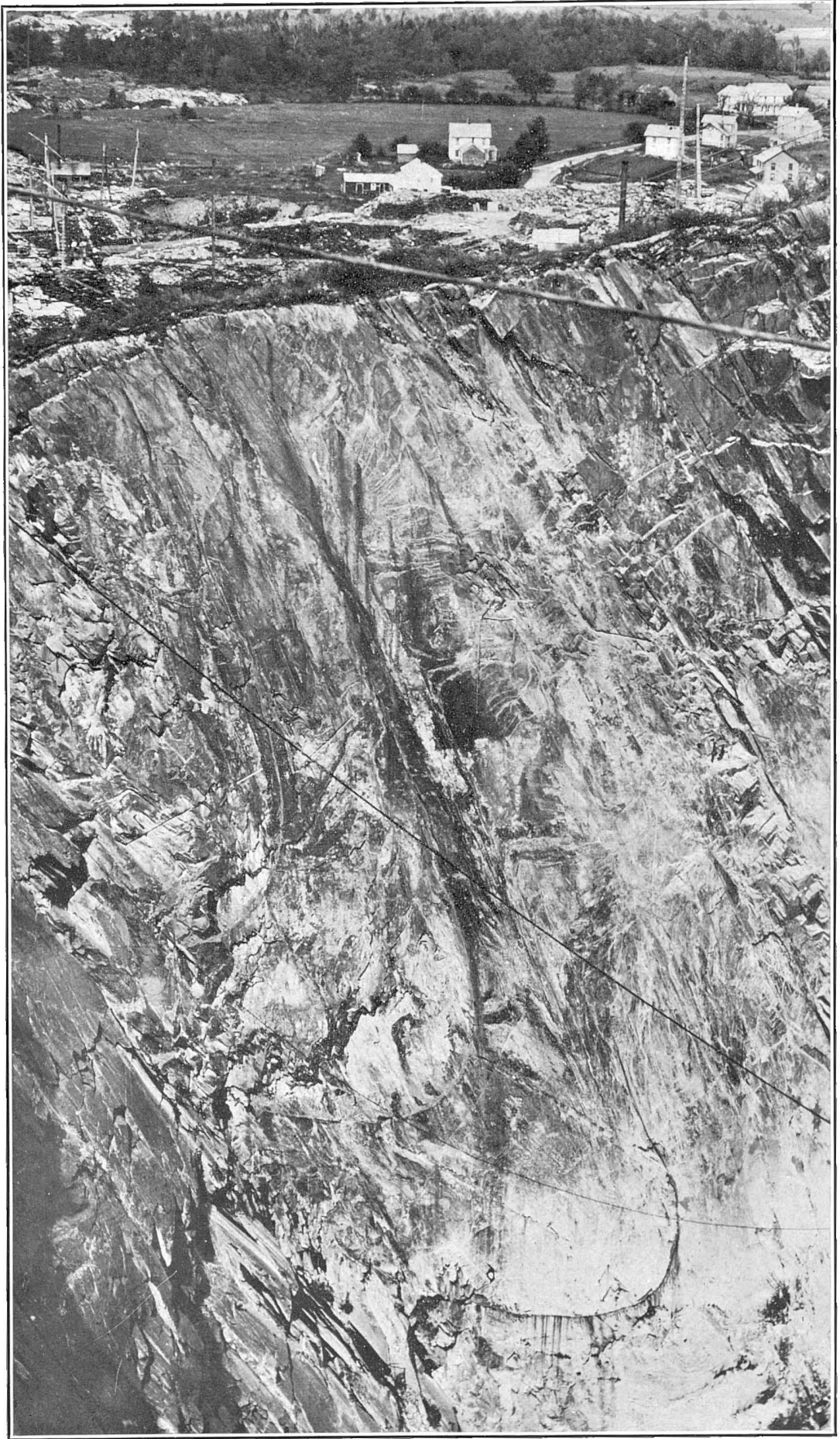

SLATE SYNCLINE AT WEST PAWLET, VT.

Rising and Nelson's sea-green slate quarry, No. 2, at West Pawlet, Vt., seen looking north, showing an eroded inclined syncline. The discoloration of the dip-joint face below is due to ferruginous water exuding at the bedding plane. Depth about 100 feet. 

eastern side of the ridge for a mile and more south consists of folded schists interbedded with quartzite, possibly belonging to (A). West of this is a strip three-fourths of a mile wide of unknown character, but from the situation of two quarries about $2 \frac{1}{4}$ miles south of a point a half mile west of the Mettawee sawmill, and from the direction of the strike of the slate at these quarries, slate probably occurs in the western half of this blank space of the section. The roofing-slate quarries from this latitude to West Pawlet lie almost all within a strip one-fourth of a mile wide along the eastern side of the Ordovician grits on the western slope of the ridge. The structure at the quarries is difficult to make out. • Bedding, where observed, dips east, as does also the cleavage. From the observed relations of the Cambrian and Ordovician wherever they occur very near each other in this region, the Cambrian overlies the latter through an overturn. An anticline should therefore occur on the Cambrian side of the boundary and a syncline on the Ordovician side of it. Not far from the Columbia quarry is a dike of camptonite, 5 feet 9 inches wide, running northeast to southwest, dipping $90^{\circ}$ or steeply to the northwest. The slate on the east side of the dike strikes north and dips $70^{\circ} \mathrm{E}$. and on the west side $55^{\circ} \mathrm{E}$. The dike has a rough jointing parallel to its sides and weathers in spherical nodules. The cleavage at the quarries dips about $55^{\circ} \mathrm{E}$. West of the quarries are greenish shales and schists with small quartzite beds striking N. $5^{\circ}$ E. and dipping $45^{\circ}-50^{\circ}$ E., measuring, apparently, about 125 feet, but possibly less, if close folded. These probably belong in the Ordovician. West of these come the Hudson grits, dipping $65^{\circ} \mathrm{E}$.

SECTION VII. - WEST PAWLET.

This crosses the West Pawlet quarries and reaches the other Cambrian belt west of Indian River. The West Pawlet belt ends abruptly south of the village, with Hudson grits south, east, and west.

Some of the quarries are over 175 feet in depth. At the Hughes quarry No. 7 there is a syncline with an anticline east of it (see fig. C on Pl. XXIII), and the foreman stated to the writer that another one was found later east of it. The pinching out of the material between the folds observed at the Mettawee gorge recurs here. At the Rising \& Nelson quarry No. 2 the syncline is finely shown ( $\mathrm{Pl}$. XXV and fig. A on Pl. XXIII). We have here an isoclinal syncline with its axial plane dipping east with the cleavage. In such a structure the same beds of course occur on either side of the fold in opposite order and also at the bottom, but there in greater thickness. The structure indicated is a syncline with an anticline on either side of it, but, unless faulting occurred, these must be parts of an anticline and the Hudson grits, which crop out in the village and at the foot of the dumps, should be part of a syncline. The strike of the slates ranges from N. $12^{\circ}$ to N. $25^{\circ}$ E., and that of the cleavage N. $5^{\circ} \mathrm{W}$. to N. $5^{\circ} \mathrm{E}$., dip $70^{\circ}$, but in places $40^{\circ}$ to $50^{\circ} \mathrm{E}$. The thickness exposed, measured across two synclines and one anticline, is about 100 feet. There are some dark-gray or "black" beds on the east side of the syncline which, according to this construction, would belong not on top, but within the roofing slates (B). The Hudson grits west of the Cambrian slates strike N. $10^{\circ}$ to $20^{\circ} \mathrm{E}$. and dip $55^{\circ}$ to $60^{\circ} \mathrm{E}$., but at the West Pawlet railroad depot this changes to N. $5^{\circ} \mathrm{W}$. and the dip to $80^{\circ} \mathrm{E}$.

In the Indian River Valley neither the few red slate quarries nor the scattering outcrops afford very satisfactory data. The folds are probably numerous and overturned so as to give only easterly dips. Mr. Walcott has indicated a graptolite locality on the west side of the valley.

The Cambrian ridge at the west has a few old purple slate quarries. Some Cambrian fossils occur in the limestone. Along the eastern side of the ridge the Cambrian shales (D) occur. About a half mile east of South Granville, near the Ordovician boundary, west of this Cambrian belt, the purple slates dip $40^{\circ} \mathrm{W}$., with a cleavage dipping $30^{\circ} \mathrm{E}$. and striking $\mathrm{N} .15^{\circ} \mathrm{E}$., the bedding forming green bands on the cleavage surfaces. The second Cambrian ridge is clearly anticlinal in structure. 


\section{GENERAL STRUCTURAL FEATURES.}

From the foregoing sections, necessarily more or less incomplete, the general structural characteristics of the western Vermont and eastern New York slate belt can be grasped. The structure of the Cambrian slate mass, which usually adjoins the Ordovician schist, is illustrated in sections VI and VII. There are close folds, more or less overturned to the west, with eastward-dipping slaty cleavage obscuring the bedding. The folds are so close and the cleavage is so pronounced that the cores of adjoining synclines and anticlines are brought very near together, or the anticlinal portions of several adjacent folds do not appear. In the northern part of the Cambrian area quartzite beds are more abundant within the roofing slates than in the southern. Although the entire mass of slate and quartzite is in places thrown into folds so greatly overturned that their axial planes are nearly horizontal, yet the slate itself is less distorted in the direction of the cleavage than in the southern area, and the cleavage itself is also less perfect in the northern than in the southern. Series of such various folds form compound anticlines and these minor Cambrian anticlinoria alternate with Ordovician synclinoria overlying Cambrian ones in apparent but not real conformity. As the Ordovician areas consist of shales, slates, grits, and small quartzite beds, the beds being more heterogeneous, slaty cleavage is less prevalent, but the folds are also overturned toward the west (see sections I, II, V, VI, VII, Pl. XXII).

A north-northwesterly strike appears in the Cambrian rocks about Blissville and again at Cedar Point (see map, Pl. XX). Large beds of quartzite overlie the roofing slate and are typical of this portion (section III, Pl. XXII).

\section{GEOLOGICAL AND GEOGRAPHICAL DISTRIBUTION OF THE VARIETIES OF SLATE.}

The quarry maps, Pls. XX and XXI, show that the slate quarries situated within the Cambrian areas are generally very near to or not far from the edge of the Ordovician belts. In some places (as in Pawlet, Wells, West Castleton) the Cambrian slates occur within 100 or 200 feet of the Hudson grits. This is the case in such a variety of situations that the proximity of the two formations can hardly be explained by faulting. The Cambrian roofing slates are, therefore, regarded as occurring not far from the top of the Lower Cambrian series as exposed in this region and very near the overlying Ordovician. As the Cambrian belts are made up of numerous folds, generally close and overturned, the slates also occur toward the center of the belts, but their stratigraphical position is still the same. The first place to look for the Cambrian roofing slates is near the Cambro-Ordovician boundary. Where the red slate occurs in close proximity to and on the west side of the Cambrian green and purple slates and the dip is easterly, as it usually is, the red slate may be found underlying the "sea green," "unfading green," or purple slates, and vice versa; on the eastern side of the Cambrian areas the green and purple slates of the Cambrian may be found underlying the red of the Ordovician when both dip easterly. At several points (Blissville, Eureka, etc.) away from the Ordovician boundary the rock which appears to immediately underlie the Cambrian slates is the Olive grit (A), one of the so-called "wild rocks" of the quarrymen. It is uncertain whether there may not be one or more beds of slate interbedded with this. The rock which overlies the Cambrian slate is either the Black Patch grit (C) or the Cambrian black shale (D) or the Ferruginous quartzite and sandstone (E). Perhaps most generally there is a bed of limestone conglomerate or breccia, followed by black shales or slates (D), see page 94. These vertical relations are pretty well established.

The areal relations of the "sea green" and the "unfading green" are not at all clear. There is nothing as yet to show that the stratigraphical position of these two varieties of Cambrian slates is not identical. It seems probable that, at the latitude 
of a point within 2 miles north of Poultney, a change in the sediments occurred in Cambrian time sufficient to account for the diminished percentage of carbonate and the increase of chlorite and pyrite." Whether this difference in composition is alone sufficient to account for the difference in the cleavage is uncertain. There may have been some difference in the resistance to pressure which would account for more perfect cleavage at the south than at the north. Possibly, as has already been suggested, the greater abundance of grains of quartz at the north may have restrained the cleavage structure, and so with more lime deposited at the south and more quartz sand at the north the whole structural difference may be traced back to changes in sedimentation.

Even this demarcation between the fading and unfading green slate areas is not absolute, for fading green slates occur well within the unfading green area, as at an old quarry $1 \frac{1}{2}$ miles southwest of West Castleton and again $1 \frac{1}{4}$ miles south of Castleton and also a half mile south of Bomoseen. Slates which fade little are reported as occurring on the ridge west of Lake St. Catherine. In an old quarry about a half mile east of Jamesville, in a belt which seems to be directly continuous with that in which lie the Eureka and adjacent quarries, the slates fade comparatively little. In the Jamesville belt, at a quarry about 180 feet above the road and west of the chapel, there is a purple bed, probably overlying a green one; both purple and green fade badly, but on the west side of the purple, i. e., underlying it, is a green bed which scarcely fades and which, under the microscope, shows very few carbonate rhombs.

A few things should be noted. The continuation of the West Pawlet slate is to be looked for in the lenticular Cambrian area which begins 2 miles south of West Pawlet and stretches across the New York State line into Hebron. Sea green and purple slates also occur in the Cambrian area southeast of West Pawlet. The Jamesville belt continues south into the village of Granville. About the north end of Lake St. Catherine the Cambrian slate belt divides in two, one part passing a half mile east of Poultney and the other a half mile east of East Poultney, where it crops out in the small gorge of the Poultney River. North of Castleton the strikes frequently change to the northwest or the north-northwest, and the beds of slate sometimes follow this direction. Barker Hill and Wallace Ledge both have Cambrian slates about them.

\section{QUARRY S'TRUC'TURE.}

The types of structure exhibited at the quarries are shown in diagrams $A-G$, $\mathrm{K}-\mathrm{T}$, and V, on Pls. XXIII and XXIV, and also in Pl. XXV, reproduced from a photograph. The following table contains the more important compass observations taken at the quarries. The numbers in the first column will be found on the maps, Pls. XX and XXI. Where cleavage is given, but not bedding, the bedding is very nearly or quite the same as the cleavage. The usual dip joints may be assumed when not given. Approximations are indicated by the signs, plus $(+)$, minus $(-)$, more or less $( \pm)$.

To the data should be added a few observations at quarries outside the areas shown in the maps. An abandoned quarry three-fourths mile south of Fair Haven shows 24 feet of purple slate overlain by about 9 feet of greenish slate, dipping $15^{\circ}-20^{\circ}$ E. and containing three beds of quartzite, each 2 inches thick. The cleavage strikes N. $10^{\circ}$ W., dips $25^{\circ}-30^{\circ}$ E. Joints strike N. $35^{\circ}$ E., dip $60^{\circ}$ E., also N. $50^{\circ}$ E., dip $90^{\circ}$. There is a fatal secondary cleavage- "false cleavage"--here, striking about north-south. See Pl. VI, $A$, and p. 24. At the Meadow Slate Company (Diagrams $\mathrm{Q}, \mathrm{R}, \mathrm{Pl}$. XXIV) and at the quarry just north of it bedding strikes $\mathrm{N} .15^{\circ} \mathrm{E}$, cleavage N. $7^{\circ}-15^{\circ} \mathrm{W} ., \operatorname{dip} 15^{\circ}-20^{\circ} \mathrm{E}$. Vertical strike joints strike N. $15^{\circ} \mathrm{E}$. and vertical dip joints N. $85^{\circ}$ W. Diagonal ones strike NW., dip $65^{\circ}$ NE., also N. $58^{\circ}$ E., dip $90^{\circ}$.

a The most southerly outcrop of decidedly unfading green observed by the writer occurs $2 \frac{1}{2}$ miles north-northeast of Poultney and three-fourths of a mile east of the railroad. 
Slate-quarry observations.

\begin{tabular}{|c|c|c|c|c|c|c|c|c|c|c|c|c|c|c|c|}
\hline \multirow{2}{*}{$\begin{array}{c}\text { Quarry } \\
\text { number. }\end{array}$} & \multicolumn{2}{|c|}{ Beddin.} & \multicolumn{2}{|c|}{ Cleavage. } & \multicolumn{2}{|c|}{ Strike joints. } & \multicolumn{2}{|c|}{ Dip joints. } & \multicolumn{2}{|c|}{ Diagonal joints. } & \multirow{2}{*}{$\begin{array}{l}\text { Grain } \\
\text { strike. }\end{array}$} & \multicolumn{2}{|c|}{$\begin{array}{l}\text { Shear zones (" hog- } \\
\text { backs"). }\end{array}$} & \multicolumn{2}{|c|}{ Faults. } \\
\hline & Strike. & Dip. & Strike. & Dip. & Strike. & Dip. & Strike. & Dip. & Strike. & Dip. & & Strike. & Dip. & Strike. & Dip. \\
\hline $10 .$. & N. + & $30^{\circ} \mathrm{E}$ & N. & $42^{\circ} \mathrm{E}$ & N. $5^{\circ} \mathrm{W}$. & $40^{\circ} \mathrm{E}$ & & & & & & N. $37^{\circ} \mathrm{E}$. & $65^{\circ} \mathrm{NW}$. & & \\
\hline 11.. & N. $5^{\circ} \mathrm{E}$. & $40^{\circ} \mathrm{E}$ & N. & $40^{\circ} \mathrm{E}$ & $\left\{\begin{array}{c}\mathrm{N} .15^{\circ} \mathrm{E} \\
\mathrm{N}\end{array}\right.$ & $\begin{array}{l}65^{\circ} \mathrm{E} . \\
45^{\circ} \mathrm{W} .\end{array}$ & N. $75^{\circ} \mathrm{W}$. & $90^{\circ}$ & & & $\left\{.\left(\begin{array}{l}\text { Bottom } \\
\text { joints. })\end{array}\right.\right.$ & & & & \\
\hline $12 \ldots$ & N. $20^{\circ} \mathrm{E}$. & $(?)$ & N. & $\left\{\begin{array}{c}40^{\circ}-70^{\circ} \\
\mathrm{E}\end{array}\right.$ & $\begin{array}{l}\text { N. } 15^{\circ} \mathrm{E} . \\
\text { N. } 10^{\circ} \mathrm{E} .\end{array}$ & $\left.\begin{array}{l}62^{\circ} \text { E. } \\
30^{\circ} \mathrm{W} .\end{array}\right\}$ & N. $75^{\circ} \mathrm{E}$ & $90^{\circ}$ & & & & & & & \\
\hline $13 .$. & N. + & E. low. & N. & $40^{\circ} \mathrm{E}$ & N. $5^{\circ} \mathrm{E}$ & $65^{\circ} \mathrm{E}$ & E.-W. & $90^{\circ}$ & & & & & & & \\
\hline $14 .$. & N. $25^{\circ} \mathrm{E}$. & $25^{\circ} \mathrm{E}$ & N. $15^{\circ} \mathrm{E}$. & $50^{\circ} \mathrm{E}$ & $\left\{\begin{array}{l}\mathrm{N} .7^{\circ} \mathrm{E} . \\
\mathrm{N} .25^{\circ} \mathrm{E} .\end{array}\right.$ & $\left.\begin{array}{l}50^{\circ} \\
45^{\circ} \\
\mathrm{W} . \\
\mathrm{W} .\end{array}\right\}$ & & & & & & & & & \\
\hline $15 \ldots$ & N. + & $37^{\circ} \mathrm{E}$ & N. $15^{\circ} \mathrm{E}$. & $55^{\circ} \mathrm{E}$ & & & & & & & & $\begin{array}{l}\text { E.-W. } \\
\text { NE. }\end{array}$ & $\begin{array}{l}\text { S. high } \\
\text { Nw. }\end{array}$ & & \\
\hline $16 \ldots$ & N.+ & $30^{\circ}$ E. \pm & N. + & $50^{\circ}$ E. \pm & N.t & E. high. & & & & & & NE. or N. & $\begin{array}{l}40^{\circ} \mathrm{NW} . \\
\text { or W. }\end{array}$ & & \\
\hline $17 \ldots$ & N.+ & $20^{\circ} \pm \mathrm{E}$ & N.t & $40^{\circ} \pm \mathrm{E}$ & $\left\{\begin{array}{l}\text { N. }+ \\
\text { N.+ }\end{array}\right.$ & $\left.\begin{array}{c}90^{\circ} \\
30^{\circ} \mathrm{W} .\end{array}\right\}$ & & & & & & & & & \\
\hline $18 .$. & ……… & $50^{\circ} \mathrm{E} . ?$ & N. & $37^{\circ} \mathrm{E}$ & N. $12^{\circ} \mathrm{W}$. & $60^{\circ} \mathrm{E}$ & $\left\{\begin{array}{l}\mathrm{E} .-\mathrm{W} . \\
\mathrm{E} .-\mathrm{W}\end{array}\right.$ & $\begin{array}{c}55^{\circ} \mathrm{W} . \\
90^{\circ}\end{array}$ & & & & & & & \\
\hline $19 .$. & & & N. & $35^{\circ} \mathrm{E}$. & $\left\{\begin{array}{c}\mathrm{N} .10^{\circ} \mathrm{E} . \\
\mathrm{N} .\end{array}\right.$ & $\left.\begin{array}{l}55^{\circ} \mathrm{E} . \\
40^{\circ} \\
\mathrm{E} .\end{array}\right\}$ & N. $82^{\circ} \mathrm{E}$ & $90^{\circ}$ & & & Feeble. & $N$. & $50^{\circ} \mathrm{E}$. & & \\
\hline $20 \ldots$ & N.t & $30^{\circ} \mathrm{E}$ & N. $10^{\circ} \mathrm{W}$. & $50^{\circ} \mathrm{E}$. & N. & $60^{\circ} \mathrm{W}$ & E.-W. & $90^{\circ}$ & & & N. $45^{\circ} \mathrm{E}$. & NE. \pm & $57^{\circ} \mathrm{NW}$ & & \\
\hline $21 \ldots$ & N. + & $17^{\circ} \mathrm{E}$ & N. $5^{\circ} \mathrm{W}$. & $42^{\circ} \mathrm{E}$. & n........... & ......... & E.-W. & $90^{\circ}$ & & & & & & & \\
\hline $22 \ldots:$ & $(?)$ & $(?)$ & N. $20^{\circ} \mathrm{W}$. & $40^{\circ} \mathrm{E}$ & N. $5^{\circ} \mathrm{W}$. & $55^{\circ} \mathrm{W}$ & N. $80^{\circ} \mathrm{E}$. & $90^{\circ}$ & & & N. $80^{\circ} \mathrm{W}$. & N. $45^{\circ} \mathrm{E}$. & $70^{\circ} \mathrm{NW}$. & & \\
\hline $23 \ldots$ & N. $25^{\circ} \mathrm{W}$. & $30^{\circ} \mathrm{E}$ & N. $25^{\circ} \mathrm{W}$. & $32^{\circ} \mathrm{E}$. & $\left\{\begin{array}{l}\mathrm{N} . \\
\mathrm{N} .+\end{array}\right.$ & $\begin{array}{c}75^{\circ} \mathrm{E} \\
45^{\circ} \pm \mathrm{W}\end{array}$ & & & & & & & & & \\
\hline $24 \ldots \ldots$ & $(?)$ & (?) & N. $17^{\circ} \mathrm{W}$. & $40^{\circ} \mathrm{E}$ & N. $10^{\circ} \mathrm{W}$. & $50^{\circ} \mathbf{E}$ & N. $65^{\circ} \mathrm{E}$. & $90^{\circ}$ & & & & & & & \\
\hline $25 \ldots \ldots \ldots$ & (?) & $(?)$ & N. $25^{\circ} \mathrm{E}$. & $65^{\circ} \mathrm{E}$. & $\cdots$ & & & & & & & & & & \\
\hline $26 \ldots \ldots .$. & $\mathrm{N}$ & $-45^{\circ} \mathrm{E}$. & N. $15^{\circ} \mathrm{E}$. & $45^{\circ} \mathrm{E}$. & N. + & $42^{\circ} \mathrm{W}$ & ........... & .......... & N. $50^{\circ} \mathrm{W}$. & $70^{\circ} \mathrm{SE}$. & & & & & \\
\hline $27 \ldots$ & N. + & $20^{\circ} \mathrm{E}$ & N. $12^{\circ} \mathrm{E}$. & $40^{\circ} \mathrm{E}$ & & & N. $70^{\circ} \mathrm{W}$. & $70^{\circ} \mathrm{ESE}$ & & & & & & & \\
\hline $28 \ldots$ & $\mathrm{N}$ & $25^{\circ} \mathrm{E}$. & N. $15^{\circ} \mathrm{E}$. & $37^{\circ} \mathrm{E}$. & & & & & & & & & & & \\
\hline $29 \ldots \ldots$ & N. + & $20^{\circ} \mathrm{C}$ & N.+ & $27^{\circ} \mathrm{E}$ & & & & & & & & & & & \\
\hline $30 \ldots$. & N.t & $22^{\circ} \mathrm{E}$ & N.t & $35^{\circ} \mathrm{E}$ & ..... & & & & & & & & & & \\
\hline $31 \ldots \ldots \ldots$ & (?) & $(?)$ & N. $10^{\circ} \mathrm{W}$. & $45^{\circ} \mathrm{E}$ & N. & $75^{\circ} \mathrm{E}$ & E.-W. & $90^{\circ}$ & & & & N. $10^{\circ} \mathrm{W}$. & $45^{\circ} \mathrm{E}$ & & \\
\hline $43 \ldots \ldots \ldots \ldots$ & N. $10^{\circ} \mathrm{W}$. & Fold. & N. $10^{\circ}$ E. & $20^{\circ} \mathrm{E}$ & & & & & & & & & & & \\
\hline
\end{tabular}




\begin{tabular}{|c|c|c|c|c|c|c|c|c|c|c|c|c|c|c|c|}
\hline $45 .$. & $\begin{array}{l}\text { N. } 7^{\circ} \text { W. } \\
\text { N. }+\end{array}$ & $\left\{\begin{array}{c}45^{\circ} \mathrm{E} . \\
35^{\circ}- \\
65^{\circ} \mathrm{E} .\end{array}\right\}$ & $\begin{array}{c}\text { N. } \\
\text { N. } 7^{\circ} \mathrm{W} .\end{array}$ & $\left\{\begin{array}{c}30^{\circ} \mathrm{E} . \\
50^{\circ} \text { to } \\
65^{\circ} \mathrm{E} .\end{array}\right\}$ & $\begin{array}{c}\text { N. } 18^{\circ} \text { E. } \\
\text { N. }\end{array}$ & $\begin{array}{c}45^{\circ}+ \\
90^{\circ}\end{array}$ & $\begin{array}{l}\text { E.-W. } \\
\text { E.-IT. }\end{array}$ & $\begin{array}{l}90^{\circ} \\
90^{\circ}\end{array}$ & & & & & & & \\
\hline $46 \ldots$ & N. $15^{\circ} \mathrm{E}$. & $60^{\circ} \mathrm{E}$ & N. $15^{\circ} \mathrm{E}$. & $60^{\circ} \mathrm{E}$ & & & & & & & & & & & \\
\hline $47 \ldots$ & N. $55^{\circ} \mathrm{E}$. & $20^{\circ} \mathrm{E}$. & N. $30^{\circ} \mathrm{E}$. & $25^{\circ} \mathrm{E}$. & N. $20^{\circ} \mathrm{E}$. & $60^{\circ} \mathrm{E}$ & & & & & & & & & \\
\hline $48 \ldots$ & $\begin{array}{c}\text { N. } 25^{\circ} \mathrm{E} . \\
(a)\end{array}$ & $20^{\circ} \mathrm{E}$. & $\begin{array}{l}\text { N. } 7^{\circ} \mathrm{E} . \\
\text { N. } 25^{\circ} \mathrm{W} .\end{array}$ & $\begin{array}{l}25^{\circ} \mathrm{E} . \\
20^{\circ} \mathrm{E} .\end{array}$ & N. $25^{\circ} \mathrm{E}$. & $45^{\circ} \mathrm{E}$. & $\begin{array}{l}\text { N. } 80^{\circ} \text { W. } \\
\text { E.-W. }\end{array}$ & $\begin{array}{c}80^{\circ} \mathrm{N} . \\
90^{\circ}\end{array}$ & $\left\{\begin{array}{l}\text { N. } 30^{\circ} \mathrm{E} . \\
\mathrm{N} .40^{\circ} \mathrm{E} . \\
\mathrm{N} .35^{\circ} \mathrm{E} .\end{array}\right.$ & $\begin{array}{l}45^{\circ} \mathrm{E} . \\
50^{\circ} \mathrm{SE} . \\
60^{\circ} \mathrm{SE} .\end{array}$ & N. $60^{\circ} \mathrm{W}$. & 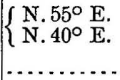 & $\left.\begin{array}{l}87^{\circ} \mathrm{NW} . \\
80^{\circ} \mathrm{NW}\end{array}\right\}$ & N. $80^{\circ}$ E. & $35^{\circ} \mathrm{S}$ \\
\hline $50 \ldots \ldots$ & N. & $20^{\circ} \mathrm{E}$ & N. $27^{\circ} \mathrm{E}$. & $30^{\circ} \mathrm{E}$. & N. $5^{\circ} \mathrm{W}$ & $30^{\circ} \mathrm{E}$. & N. $65^{\circ} \mathrm{W}$. & $90^{\circ}$ & & & & & & & \\
\hline $51 \ldots \ldots$. & ....... & $0^{\circ}$ & N.+ & $17^{\circ} \mathrm{E}$. & & & & & & & & & & & \\
\hline $52 \ldots$ & . $\ldots \ldots \ldots$ & $0^{\circ}$ & N. $25^{\circ} \mathrm{E}$. & $15^{\circ} \mathrm{E}$. & & & N. $70^{\circ} \mathrm{E}$. & $90^{\circ}$ & & & & & & Along el & eavage. \\
\hline $53 \ldots$ & N. $40^{\circ} \mathrm{W}$. & Fold. & N. $15^{\circ} \mathrm{E}$. & E. low. & & & & & & & & & & & \\
\hline 54. & N. $17^{\circ} \mathrm{W}$. & $30^{\circ} \mathrm{E}$. & N. $5^{\circ}$ E. & $20^{\circ} \mathrm{E}$. & & & & & & & & & & & \\
\hline $56 \ldots$. & N. $75^{\circ} \mathrm{W}$. & $17^{\circ} \mathrm{S}$. & N. $42^{\circ} \mathrm{E}$. & $15^{\circ} \mathrm{E}$. & N. $22^{\circ} \mathrm{E}$ & $60^{\circ} \mathrm{E}$. & & & & & & & & & \\
\hline $57 \ldots$. & N.+ & $7^{\circ} \mathrm{W}$ & N.t & $17^{\circ} \mathrm{E}$. & & & & & & & & & & & \\
\hline $58 \ldots$ & N. + & $15^{\circ} \mathrm{W}$. & N. $10^{\circ}$ E. & $17^{\circ} \mathrm{E}$. & & & & & & & & & & & \\
\hline
\end{tabular}




\section{SLATE DEPOSITS AND INDUSTRY OF UNITED STATES.}

The grain strikes N. $35^{\circ}$ W. At the Scotch Hill quarries (Diagram S, Pl. XXIV), 2 miles north-northeast of Fair Haven, the beds strike N. $25^{\circ}$ W., dip $5^{\circ}$ E., cleavage with same strike dips $15^{\circ}$ E. The joints are vertical, striking N. $5^{\circ}-17^{\circ}$ E. and N. $67^{\circ} \mathrm{W}$. At the recently opened quarries of the Brandon Slate Company, 4 miles southwest of Brandon village, in Sudbury, the beds strike N. $55^{\circ}$ E., dip $35^{\circ}$ SE., and in places the cleavage is parallel to it. In some of the slate ledges, east-southeast of their first opening, there is a false cleavage striking N. $25^{\circ} \mathrm{W}$.

\section{MINOR STRUCTURAL FEATURES.}

The purplish slates frequently have greenish ribbons-calcareous, quartzitic, and chloritic-an inch or two in thickness, and such ribbons run into rows or planes of green spots. The cause of these colored beds and spots has been discussed on page 17. The ribboned slates here, as elsewhere, are used for flagging.

In some of the quarries there are pyritiferous quartzite nodules a few inches in diameter, of lenticular form, lying in the bedding foliation and of sedimentary origin (see p. 33).

Faults of no great displacement are not uncommon. These may be reversed or normal (see Pl. IV, C, E, and p. 29).

Veins of milky quartz are abundant and sometimes attain large dimensions (see Pl. V and p. 32). Their course is often very irregular. They are apt to contain calcite and chlorite.

As shown by the maps, Pls. XX, XXI, the region is traversed by dikes. These measure from 12 to 40 and more feet in width and up to several miles in length. They are of Ordovician or later date and are usually of camptonite, consisting chiefly of plagioclase feldspar and hornblende, with or without augite. ${ }^{a}$

These dikes are sometimes parallel to the strike or the dip joints, but more frequently to the diagonal joints.

Shear zones ("hogbacks") are of frequent occurrence, as is shown by the quarry diagrams, Pls. XXIII, XXIV. From their parallelism to the dikes and some of the joints they may all be due to the same earth movement-(see, on shear zones, Pl. VII and p. 29, and on their relation to dikes, p. 44).

The quartzite beds, the veins, dikes, shear zones, "posts," faults, and diagonal joints add seriously to the difficulties presented by the overturned close folding and the pinching out of folds which characterize this region. False cleavage is, however, exceptional.

\section{'THE WESTERN VERMONT SLATES.}

"Sea-green" slate.-This, when freshly quarried, varies from a light gray to a slightly greenish gray. In some beds it is crossed by ribbons of a dark gray or, when bedding and cleavage are parallel, it bears traces of organisms in dark gray. To the unaided eye the texture is fine and the cleavage surface somewhat so, with a waxy luster. The sawn edges show a little pyrite. It is very slightly magnetitic, effervesces slightly under cold dilute hydrochloric acid applied to the edges, is quite sonorous and very fissile. After a few years exposure it changes its color to a brownish gray, and as the beds discolor differently a roof covered with "sea-green" slates from different beds acquires a mottled color.

Under the microscope it shows a matrix of muscovite (sericite), with brilliant aggregate polarization and of very fine texture, crossed here and there by obscure traces of bedding. This matrix incloses more or less angular grains of quartz measuring from 0.05 to 0.34 by 0.004 to $0.035 \mathrm{~mm}$., but usually 0.035 by $0.013 \mathrm{~mm}$., an occasional grain of plagioclase (lime-soda) feldspar up to 0.04 by $0.05 \mathrm{~mm}$. Sections parallel to the cleavage show many plates and rhombs of carbonate, the latter

$a$ See Miss F. Bascom's study of these dike rocks in Nineteenth Ann. Rept., pt. 3, 1899, p. 223-226. 
measuring from 0.003 to 0.015 and even $0.05 \mathrm{~mm}$. in diameter. These sometimes consist of two crystals, an inner rhomb and an outer one, with different orientation, possibly in twinned position. In some cases the central rhomb has fallen out, in others the rhomb has an opaque mineral nucelus which is not pyrite (magnetite or graphite?). There are also a few scales of chlorite with interleaved muscovite up to $0.13 \mathrm{~mm}$., with their laminæ across both grain and cleavage, and some equally large muscovite scales, possibly of sedimentary origin. There are some irregularly distributed pyrite spherules from 0.003 to $0.02 \mathrm{~mm}$., also minute lenses of pyrite. Rutile needles, measuring from 0.0017 to 0.009 , rarely 0.012 , by $0.002 \mathrm{~mm}$., average from 1,000 to 1,850 per square millimeters, which is equivalent to from 645,000 to $1,200,000$ per square inch; rarely a grain of zircon or prism of tourmaline 0.022 by $0.008 \mathrm{~mm}$.

The chief constituents of this slate, arranged in descending order of abundance, appear to be muscovite (sericite), quartz, carbonate, chlorite, rutile, pyrite, magnetite. $a$

In order to ascertain the cause of the discoloration thin sections across the discolored surface of a slate which had been exposed three years were examined and it was found that while the carbonate rhombs within the body of the slate were transparent in ordinary light those at the surface were changed to the color of limonite. These rhombs measured $0.047 \mathrm{~mm}$. A cleavage surface of the same slate was also affixed to the glass slide and the other side was ground down. 'This showed a multitude of rhombs, generally ranging in size from 0.008 to $0.013 \mathrm{~mm}$., entirely or partially altered to limonite. In some cases there was a yellowish brown zone of alteration surrounding an unaltered nucleus. These rhombs are regarded by Doctor Hillebrand as an isomorphous mixture of dolomite and siderite, i. e., a carbonate of lime, magnesia, and iron, in which the iron (ferrous carbonate) oxidizes into limonite. $b$ The only way to prevent this discoloration would be to coat the slate.with some preparation which would protect it from oxidation.

Some of the sea-green slates are termed hard, others soft. The difference, judging from microscopic evidence, seems to be due to the greater percentage of carbonate in the soft ones and the larger size of the quartz grains in the hard ones.

The following complete analyses of sea-green slate were made by Dr. W. F. Hillebrand, chemist of the United States Geological Survey:

Analyses of Vermont "sea-green" roofing slate.

\begin{tabular}{|c|c|c|c|c|}
\hline . & A. & B. & C. & D. \\
\hline 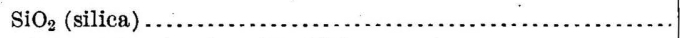 & 67.76 & 62.37 & 59.84 & 65.29 \\
\hline $\mathrm{TiO}_{2}($ rutile; titanium dioxide $) \ldots \ldots \ldots \ldots \ldots \ldots \ldots \ldots \ldots \ldots \ldots \ldots \ldots \ldots \ldots$ & .71 & .74 & .74 & \\
\hline $\mathrm{Al}_{2} \mathrm{O}_{3}$ (alumina) $\ldots$ & 14.12 & 15.43 & 15.02 & \\
\hline 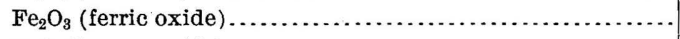 & .81 & 1.34 & 1.23 & \\
\hline 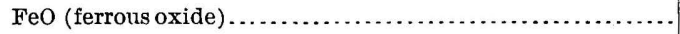 & 4. 71 & 5.34 & 4. 73 & \\
\hline Mno (manganese oxide) ......................... & .10 & .22 & .34 & \\
\hline $\mathrm{NiO}, \mathrm{CoO}$ (nickelous and cobaltous oxide) ......... & Trace? & Trace. & Trace. & \\
\hline $\mathrm{CaO}$ (lime) & .63 & .77 & 2.20 & \\
\hline 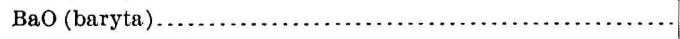 & .04 & .07 & .09 & \\
\hline 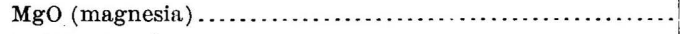 & 2.38 & 3.14 & 3.41 & \\
\hline 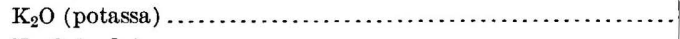 & 3.52 & 4.20 & 4. 48 & \\
\hline 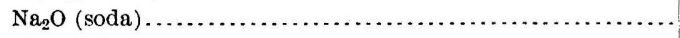 & 1.39 & 1.14 & 1.12 & \\
\hline 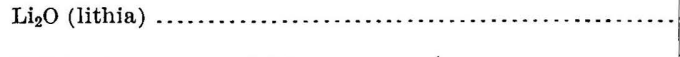 & $\begin{array}{c}\text { Strong } \\
\text { trace. }\end{array}$ & Trace. & $\begin{array}{l}\text { Strong } \\
\text { trace. }\end{array}$ & \\
\hline $\mathrm{H}_{2} \mathrm{O}$ (water below $110^{\circ}$ C. ) ..... & .23 & .34 & .41 & \\
\hline
\end{tabular}

a For colored lithographs of magnified thin sections of this slate as seen under both ordinary and

polarized light, see Nineteenth Ann. Rept. U. S. Geol. Survey, pt. 3, Pl. XXXV.
$b$ See Doctor Hillebrand's Chemical notes on the composition of the roofing slates of eastern New York and western Vermont, p. 39. 
Analyses of Vermont "sea-green" roofing slate-Continued.

\begin{tabular}{|c|c|c|c|c|}
\hline & A. & B. & C. & D. \\
\hline $\mathrm{H}_{2} \mathrm{O}$ (water above $110^{\circ}$ C. $) \ldots \ldots \ldots \ldots \ldots$ & 2.98 & 3.71 & 3.44 & \\
\hline 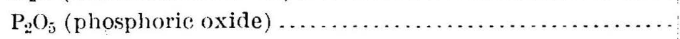 & .07 & .06 & .09 & \\
\hline 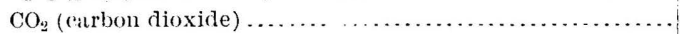 & .40 & .87 & 2.98 & \\
\hline 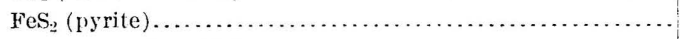 & .22 & .06 & .05 & \\
\hline 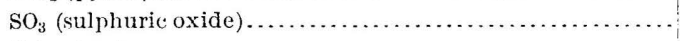 & Trace. & Trace. & Trace. & \\
\hline 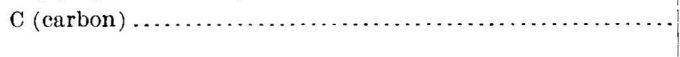 & None. & $\begin{array}{l}\text { Strong } \\
\text { trace. }\end{array}$ & Trace. & \\
\hline Fl (fluorine) ....... & & ........ & .11 & \\
\hline 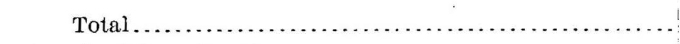 & 100.07 & 99.80 & 100.28 & \\
\hline 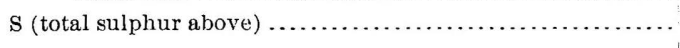 & .12 & .032 & .024 & \\
\hline
\end{tabular}

A $(=$ D. XIV , 1895, 230a), Rising \& Nelson's quarry No. 2, West Pawlet, Vermont; 13-foot bed. B (=D. XIV $1895,225 f)$, Griffith \& Nathaniel's quarry, 9 miles north of A, South Poultney, Vermont. $\mathrm{C}$ (=D. XIV, 1895, 256e), Wm. H. Hughes's quarry No. 10 (Brownell), 2 miles north of 'A, Pawlet, Vermont. D (=D. XIV, 1895, 35l), Auld \& Conger's quarry, 8 miles north of A, in Wells, Vermont; 22 -foot bed. Determination of silica only. These are all fro.n the West Pawlet and South Poultney belt.

Specific gravity: C, $2.7910 ; \mathrm{D}, 2.7627$.

This slate is used exclusively for roofing purposes. The results of Professor Merriman's recent tests of it are stated on page 123.

"Unfading green" slate. - This slate is greenish gray in color, and to the unaided eye has a somewhat fine texture and a roughish lusterless cleavage surface. The sawn edge shows some pyrite. It is magnetitic, does not effervesce with cold dilute hydrochloric acid, and is sonorous. Several years' exposure produces so little change of color that only when a fresh slate is put beside it is any change perceptible, and that is but slight. Its fissility is inferior to that of the "sea green." Under the microscope it shows a matrix of muscovite (sericite), with a brilliant aggregate polarization but considerable inequality in texture, coarser quartzose bands, with imperfect cleavage, alternating with finer more sericitic ones. In both there is irregularity in the size of the particles. Angular quartz grains ineasure from $0.01 \mathrm{by}$ 0.008 to 0.04 by 0.017 , rarely 0.07 by $0.017 \mathrm{~mm}$. There are a few lenses up to $0.2 \mathrm{by}$ $0.1 \mathrm{~mm}$. of quartz fragments and muscovite scales, also lenses up to 0.4 by $0.1 \mathrm{~mm}$. of chalcedonic quartz?. A few grains of plagioclase feldspar, scales of chlorite up to 0.039 by $0.006 \mathrm{~mm}$. parallel to the grain and also scales of muscovite in similar position. Not a few specks and lenses of pyrite, some octahedra of pyrite with rim of chlorite, carbonate rhombs- -0.026 to $0.065 \mathrm{~mm}$.- but in very much smaller number than in the sea-green slate. Abuntant rutile needles from 0.003 to $0.008 \mathrm{~mm}$. long,

The chief constituents of this slate, arrangerl in lescending order of abundance. appear to be muscovite (sericite), quartz, chlorite, carhonate, rutile, pyrite, magnetite."

These slates are relatively unfarling, becanse they have fewer rhombs and plates of carbonate." The sections also show why they cleave less perfectly than the sea-green slates.

a For colored lithographs of mugnified thin seetions of this slate, as seen both under ordinary and polarized light, see Nineteenth Ann. Rept., pt. 3, P'. XXXVI.

usee Doctor Hillebrand's note, 1', 39. 
The following analyses were made in the lahoratory of the Inited States (ieological Survey by Dr. W. F. Hillebrand:

Analyses of Vermont "unfading green" roofing slates.

\begin{tabular}{|c|c|c|c|c|c|}
\hline & E. & F. & & E. & F. \\
\hline $\mathrm{SiO}_{2}$ (silica) $\ldots \ldots \ldots \ldots \ldots \ldots$ & 59.27 & 59.48 & $\mathrm{Ii}_{2} \mathrm{O}$ (lithia ) . ........ & Trace. & Trace. \\
\hline $\mathrm{TiO}_{2}$ (titanium dioxide, rutile) & .99 & 1.02 & $\mathrm{H}_{2} \mathrm{O}$ (water below $110^{\circ} \mathrm{C}$.) ... & 0.32 & 0.17 \\
\hline $\mathrm{ZrO}_{2,}$ (zirconia) $\ldots \ldots \ldots \ldots \ldots$ & ........ & Trace? & $\mathrm{H}_{3} \mathrm{O}$ (water above $110^{\circ}$ C.) ... & 3.98 & 4.05 \\
\hline $\mathrm{Al}_{2} \mathrm{O}_{3}$ (alumina $\ldots \ldots \ldots \ldots$ & 18.81 & 18. 22 & $\mathrm{P}_{2} \mathrm{O}_{5}$ (phosphoric oxicle) ..... & .11 & .10 \\
\hline $\mathrm{Fe}_{2} \mathrm{O}_{3}$ (ferric oxide) $\ldots . \ldots \ldots$ & 1.12 & 1.24 & $\mathrm{CO}_{2}$ (carbon dioxide)...... & .21 & .39 \\
\hline FeO (ferrous oxide) ........... & 6.58 & 6. 81 & $\mathrm{FeS}_{2}$ (pyrite) $\ldots \ldots \ldots \ldots \ldots$ & .15 & .13 \\
\hline Mno (manganous oxide) ..... & .13 & .07 & SO: (sulphuric oxide).... & Truce. & … \\
\hline NiO (nickelous oxide)........ & Trace? & Trace. & $\mathrm{C}($ carbon $) \ldots \ldots \ldots \ldots \ldots \ldots$ & None. & None. \\
\hline CoO (cobaltons oxide)........ & Trace? & - & $\mathrm{Fl}$ (fluorine) .......... & & .08 \\
\hline SrO (strontia) ............... & .......... & Trace? & & & \\
\hline $\mathrm{CaO}$ (lime) $\ldots . . . \ldots$. & .42 & .56 & Total... & 99.98 & 100.23 \\
\hline 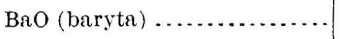 & .05 & .05 & S (total sulphur included & & \\
\hline $\mathrm{MgO}$ (magnesia) ................. & 2.21 & 2.50 & above) $\ldots \ldots \ldots \ldots \ldots$ & .08 & .07 \\
\hline $\mathrm{K}_{2} \mathrm{O}$ (potassa) $\ldots \ldots \ldots \ldots \ldots \ldots$ & 3.75 & 3.81 & Specific gravity ............ & 2.795 & \\
\hline $\mathrm{Na}_{2} \mathrm{O}($ soda $) \ldots \ldots . . . . . . . .$. & 1.88 & 1.55 & & & - \\
\hline
\end{tabular}

E (=D. XIV, '95, 314f), Eureka quarries, $3 \frac{1}{4}$ miles north of Poultney, in Poultney 'Township, Vermont. F $\left(=\mathrm{D}\right.$. XV , '96, 645a), Valley Slate Company quarry, $2 \frac{1}{2}$ miles north of Poultney, in Poultney Township, Vermont.

The results of Professor Merriman's recent tests of Vermont unfading green slate will be found on page 123 .

This slate is largely used for roofing purposes. The mill stock slate is described beyond.

"Purple" and "variegated" slate.-The "purple" slate is dark purplish brown; the "variegated" is like the "sea green" and the "unfarling green," but is irregularly patched with purplish brown. These purplish slates are interbedderl both with the sea green and the unfading green, as shown in the quarry diagrams (Pls. XXIII, XXIV). The texture, surface, and luster correspond generally to those of the slates with which they are interbedded. The purple of the sea-green areas discolors less than the sea green, but effervesces with cold dilute hylrochloric acid, and is very slightly magnetitic. The variegated of the Eureka quarry does not effervesce with cold dilute hydrochloric acid. All these slates are sonorous.

Under the microscope the purplish slate closely resembles the green, with which it is associated, both in structure and composition, excepting that the purplish contains a large amount of hematite $\left(\mathrm{Fe}_{2} \mathrm{O}_{3}\right)$ in irregular bright red dots from 0.001 to $0.003 \mathrm{~mm}$. in diameter, exceptionally in hexagonal seales. This mineral obscures the aggregate polarization. There are quartz fragments up to 0.047 and even 0.07 $\mathrm{mm}$., rare plagioclase grains; lenses of quartz a millimeter long, muscovite and chlorite scales lying at an angle to the cleavage, others without arrangement. Carbonate is less abundant than in the respective green slates. Spherules of pyrite from 0.007 to $0.027 \mathrm{~mm}$., rutile needles in abundance, a few prisms of tourmaline and rare fragments of zircon.

The chief constituents of the "purple" slate, arranged in descending order of abundance, appear to be muscovite (sericite), quartz, chlorite, hematite, carbonate, rutile, pyrite, magnetite. The purplish color is due to the mixture of the red from the hematite and the bluish green from the chlorite. $a$ In the variegated slates the mottling is produced by the irregular distribution of the hematite.

\footnotetext{
a For colored lithographs of magnified thin sections of the "purple" slate, as seen under both ordinary and polarized light, see Nineteenth Ann. Rept. U. S. Geol. Survey, pt. 3, Pl. XXXVII.
} 
The following analyses were made by Dr. W. F. Hillebrand in the laboratory of the United States Geological Survey:

Analyses of Vermont "purple" and "variegated" roofing slates.

\begin{tabular}{|c|c|c|c|c|}
\hline . & G. & H. & I. & $\mathrm{H}^{2}$. \\
\hline $\mathrm{SiO}_{2}$ (silica) $\ldots \ldots \ldots \ldots \ldots \ldots$ & 61.63 & 60.96 & 60.24 & \\
\hline 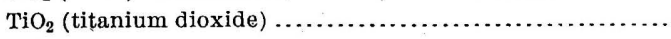 & .68 & .86 & .92 & \\
\hline 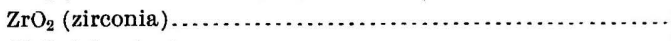 & .......... & Trace? & Trace? & \\
\hline $\mathrm{Al}_{2} \mathrm{O}_{3}$ (alumina) $\ldots \ldots \ldots \ldots \ldots \ldots \ldots$ & 16.33 & 16.15 & 18. 46 & \\
\hline $\mathrm{Fe}_{2} \mathrm{O}_{3}$ (ferric oxide) & 4.10 & 5.16 & 2.56 & 5.28 \\
\hline $\mathrm{FeO}$ (ferrous oxide) ............... & 2.71 & 2.54 & 5.18 & 2.36 \\
\hline MnO (manganous oxide) ........ & .09 & .07 & .07 & \\
\hline NiO (nickelous oxide) ............. & Trace? & Trace. & Trace. & \\
\hline $\mathrm{CoO}$ (cobaltous oxide) ............ & Trace? & Trace. & Trace. & \\
\hline 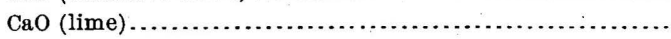 & .50 & .71 & .33 & \\
\hline 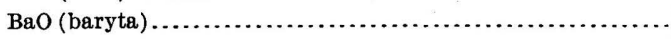 & .06 & .04 & .03 & \\
\hline 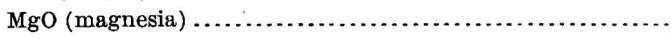 & 2.92 & 3.06 & 2.33 & \\
\hline 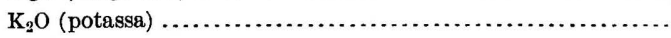 & 5.54 & 5.01 & 4.09 & \\
\hline 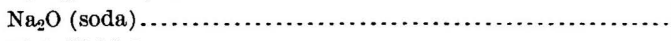 & 1.26 & 1.50 & 1.57 & \\
\hline 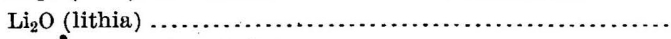 & Str. tr. & Trace. & Str. tr. & \\
\hline 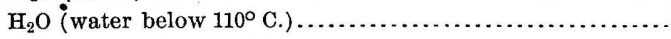 & .31 & .17 & .18 & \\
\hline 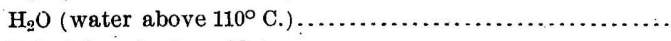 & 3.24 & 3.08 & 3.81 & \\
\hline 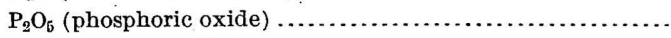 & .16 & .23 & .11 & \\
\hline 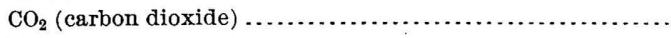 & .41 & .68 & .08 & $\cdots$ \\
\hline 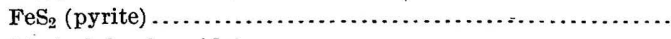 & .04 & None. & .16 & \\
\hline 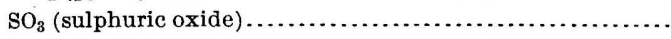 & Trace. & & & \\
\hline 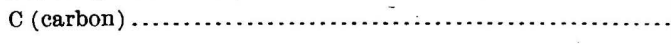 & None. & None. & None. & ..... \\
\hline & 99.98 & 100.22 & 100.12 & \\
\hline 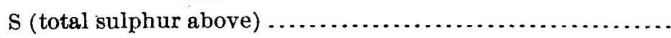 & .02 & .07 & .087 & \\
\hline 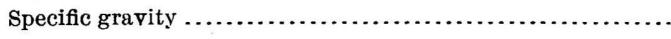 & 2.8064 & & 2.8053 & \\
\hline
\end{tabular}

G (=D. XIV, '95, 260a), purple roofing slate, McCarty quarry, east of center of Lake Saint Catherine, South Poultney, Vermont. H $(=\mathrm{D}$. XV, '95, 760a), purple roofing slate, Francís \& Sons quarry, nearly a mile south of Hydeville, in Castleton, Vermont. I ( $=\mathrm{D}$. XV, '95, 314), variegated roofing slate, from Eureka quarry, $3 \frac{1}{4}$ miles north of Poultney, in Poultney Township, Vermont, "unfading-green" area. $\mathrm{H}^{2}$ (=D. XIV,'95, 614a), dark reddish bed a few inches thick in purple of sea-green area, west of Lake Saint Catherine; determination of iron oxides only.

The results of certain tests of the strength of Fair Haven "purple" slate are given on page 124 .

The purple and variegated slates are used mainly for roofing.

Mill-stock slate.-In the northern and western part of the green-slate belt those beds which have a less perfect cleavage are used as mill stock, and find a market as blackboards, billiard-table tops, electric switchboards, tiles, vats, mantels, etc., and for some purposes are subjected to the process known as "marbleizing." They are purple or green. The purple is frequently paler than the purple roofing slate, and also spotted with green, while the green is sometimes brighter than the unfading green roofing slate.

Specimens from the Scotch Hill quarries, 2 miles north-northeast of Fair Haven; from the Meadow quarry, one-fourth mile east of Fair Haven; from the Lake Bomoseen Slate Company's quarry at Cedar Point, on Lake Bomoseen, $a$ and from the J. Jones quarry, $2 \frac{1}{2}$ miles north of Castleton, were examined microscopically, with these results:

The matrix is muscovite (sericite), with aggregate polarization, but shows a cleav- 
age much inferior to that of the sea-green slate and somewhat inferior to that of the Eureka of the unfading green. There are about 6 chlorite plates, interleaver with muscovite, to each square millimeter, measuring up to 0.087 by 0.043 millimeter and lying at right angles to the cleavage. Quartz fragments are very abundant, measuring up to 0.06 by 0.03 millimeter, with a few of plagioclase feldspar; muscovite scales in various orientation s; a few carbonate rhombs, the usual abundance of rutile needles, and, finally, pyrite, which seems to be more abundant in the purple than in the green. The purp? differs from the green by the addition of hematite.

The chief constituents, arranged in descending order of abunclance, appear to be muscovite (sericite), quartz, chlorite (hematite in the purple), carbonate, rutile (kaolin in the purple, at least), pyrite, and, as shown by a magnet test, magnetite.

The specific gravity of the purple from Cedar Point was found to be 2.83 and of the green from the J. Jones quarry 2.84 , both being a little higher than the figures for any of the other western Termont slates.

Slate-pencil slate.-In the unfading green-slate portion of the belt, about $1 \frac{1}{4}$ miles north of Bomoseen and a little east of the lake, is an abandoned quarry where certain greenish slates were obtained and made into slate pencils. In Europe slate pencils have long been made by utilizing a secondary cleavage, which breaks the rock up into squarish sticks which are easily rounded. Here, however, the method was to take tile-shaped blocks of slate and carve out first on one side, then on the other, by means of set gauges, a whole series of hemicylindrical pencils which readily broke apart into roundish pencils. A microscopic section of this rock shows essentially the same composition as the unfading green slates, excepting that sections parallel to the cleavage show no carbonate whatever, but a greater abundance and larger scales of muscovite (probably sedimentary), some limonite? specks, and a cleavage perhaps not quite so good as that of the Eureka quarries. The usual quartz, sericite, chlorite, rutile needles, and lenses are present.

The general substitution of paper tablets for school slates in this country has almost stopped the manufacture of slate pencils.

Minerals associated with the green and purple slates.-As the minerals of visible size associated with the slates throw light on the nature and origin of the microscopic constituents of the slate itself, they are here given:

Quartz is the most common accessory mineral. It is usually segregated in the veins already described, but occurs also as an infiltrated cement between the quartz grains in the beds of quartzite or in veins traversing the quartzite. In both of these modes it is crystallized whenever cavities admit of it.

Next in abundance is calcit', occurring also in veins with or without quartz, or as delicate films on joint planes, or as a sediment in the beds of quartzite. The quartzite beds sometimes contain minute rhombs which effervesce readily with hydrochloric acid and weather a limonite brown, and are therefore probably a double carbonate of iron and lime.

Squarish or oval concretions an inch by three-fourths of an inch and one-half inch thick, consisting of radiating crystalline lamellæ of barite, with the intervening spaces filled with slate and calcite and with many minute cubes of pyrite round about, occur in the Cambrian green slates of Middle Granville. Barite also occurs with calcite in crystalline films on joint planes.

Chlorite is common in quartz veins, or almost alone makes up small veins, or coats slickensided joint or bedding planes.

Pyrite occurs in cubes up to one-fourth inch across or in botryoidal concretions, coated with fibrous quartz (chalcedony) or with calcite, or, more rarely, chlorite. This coating of chalcedony is often confined to some of the sides, filling a space produced by motion or compression, as described by Renard. Pyrite may collect in the vicinity of calcareous and quartzose veins or beds, or form dendritic crystallizations 
on cleavage planes, or minute cub $\mathrm{s}$ on joint faces. That this mineral is pyrite and not marcasite is shown by its not decomposing readily after long exposure on the slate dumps. ${ }^{a}$

Rarely a little galenite occurs in the quartz veins.

It will be observed that nearly all of the above minerals have already been mentioned as occurring in the slates, as shown either by the microscopic or the chemical analyses.

Benson black slate.-Half a mile east of Benson village and $7_{2}^{1}$ miles north-northwest of Fair Haven, in Rutland county, black roofing slate was quarried in 1895, but the quarry was abandoned not long afterwards. The slate is of Ordovician age (Hudson-Utica), and belongs in a shale, slate, and schist belt which extends nearly 4 miles west to within a mile of Lake Champlain, and $t_{2}^{1}$ miles sonth-southwest to the village of West Haven, and also, with bends and ramifications, 20 miles north-northeast to Weybridge Center, in Addison county. Almost the entire area and the quarry location will be shown on the fortheoming Fort Ticonderoga folio, Economic geology sheet. The slate-bearing area, however, probably. does not exceed 12 square miles.

At the quarry the beds dip about east at angles ranging from $15^{\circ}$ to $20^{\circ}$; cleavage strikes about $\mathrm{N}$. $7^{\circ} \mathrm{E}$., dipping east at $35^{\circ}$, and vertical joints strike $\mathrm{N}$. $75^{\circ} \mathrm{W}$.

The slate is a bluish black; to the unaided eye has a somewhat fine texture and a somewhat smooth, slightly lustrous cleavage surface. It is carbonaceous or graphitic, contains a little magnetite, effervesces with cold dilute hydrochloric acid, is sonorous, and has a fair degree of fissility.

Under the microscope it shows a matrix of muscovite (sericite), with a brilliant aggregate polarization, somewhat obscured by much carbonate and carbonaceous matter in fine and coarse particles. The quart $z$ fragments measure from 0.013 to 0.03 millimeter; carbonate rhombs from $0.00+$ to 0.035 millimeter. Pyrite spherules from 0.0017 to 0.007 millimeter number about 200 per square millimeter, often occurring in rows along the cleavage. Rutile needles from 0.0017 to 0.0952 millimeter long are abundant; chlorite scales are very few and small, zircon fragments rare.

The constituents of this slate, arranged in descending order of abundance, appear to be muscovite (sericite), quartz, carbonate, pyrite, rutile, carbonaceous or graphitic matter, and magnetite.

This slate is thus closely related, both in composition and quality, to the "soit vein" slates of Lehigh and Northampton counties, Pa. Its large amount of carbonate indicates its probable discoloration on continued exposure. Its appearance in magnified thin sections under both ordinary and polarized light is very well shown in Pl. XXXIx, part 3, Nineteenth Annual Report United States Geological Survey, which would answer almost equally well for many of the Pennsylvania "soft vein" slates.

The following analysis (specimen $\mathrm{P}=\mathrm{D}$. XIV, '95, 305d) of black slate from the abandloned quarry, one-fourth mile east of Benson Village, Rutland Comnty, Vt., was also made by Dr. W. F. Hillebrand: 
Analysis of Benson black roofing slate.

$\mathrm{SiO}_{2}$ (silica)

$\mathrm{TiO}_{2}$ (titanium dioxide, rutile) ..

$\mathrm{Al}_{2} \mathrm{O}_{3}$ (alumina) ...............

$\mathrm{Fe}_{2} \mathrm{O}_{3}$ (ferric oxide) ............

$\mathrm{FeO}$ (ferrous oxide) ...........

$\mathrm{MnO}$ (manganous oxide) .........

$\mathrm{NiO}$ (nickelous oxide)........... .

$\mathrm{CoO}$ (cobaltous oxide) .......... Tra

$\mathrm{CaO}$ (lime) ..................

$\mathrm{BaO}$ (baryta) ................

MgO (magnesia) .............. .

$\mathrm{K}_{2} \mathrm{O}$ (potassa) .................

$\mathrm{Na}_{2} \mathrm{O}$ (soda)
59. $70 \quad \mathrm{Li}_{2} \mathrm{O}$ (lithia)

79 . Strong trace.

16. $98 \mathrm{H}_{2} \mathrm{O}$ (water above $110^{\circ}$ C.) ...... 3.82

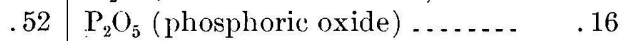

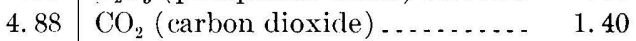

$.16 \mathrm{FeS}_{2}$ (pyrite) .................. 1.18

Trace? $\mathrm{SO}_{3}$ (sulphuric oxide)........... Trace.

Trace? C (carbon) .................. . .46

1.27 Total ................ $\overline{100.05}$

$.08 \mathrm{~S}$ (total sulphur included above) _ $\quad .63$

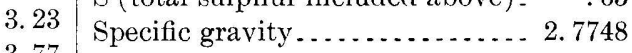

3. 77

1.35

The more important features of all these Vermont slates, as brought out in the above descriptions, will be found in tabular form opposite page 124 .

\section{VIRGINIA.}

\section{By T. Nelison DaLe.}

W. B. Rogers, in his reports to the legislature of Virginia during the years 1835 to $1841, a$ called attention to the slate deposits east of the Blue Ridge in Buckingham, Fluvanna, and Fauquier counties. Slate also occurs in the Blue Ridge in Amherst County.

Geological relations in Buckingham and Fluvanna courities.-Rogers' reference to this slate ${ }^{b}$ may well be repeated here:

This (roofing slate) makes its appearance on both sides of the James River. . . . In Buckingham the bed is largely exposed in the neighborhood of New Canton, on Slate River. . . . In texture, density, and capacity of resisting atmospheric agents it can scarcely be excelled by a similar material in any part of the world. This quarry was first opened to procure slate for roofing the Capitol, and notwithstanding it has been thus long known and its value established, but little further use has been made of it until the activity of the present owner has again brought it into notice. The building of the university will soon be furnished with a complete covering of slate from this quarry.

Slate River empties into the James about 40 miles west-northwest of Richmond and 52 miles northeast of Lynchburg. The extent and structure of the formation which includes these slate beds require further study, but fig. 12 will serve to show some of its important features. The width of the formation north of the James, as far as explored by the writer during a very brief visit, extends from a point one-half mile west of Bremo Bluff to a small creek entering the James $1 \frac{2}{5}$ miles east-southeast of Shores, a distance of 13 miles. It strikes about south-southwest across the James, having a minimum length of 4 miles. South of the James its eastern boundary lies about 3,000 feet west of the toll bridge opposite Bremo Bluff, and its western boundary is roughly one-fourth nile east of the Virginia Mills, on Slate River. The "Bremo.Bluffs," on the north side of the James, and those at New Canton, on the south side, both consist of quartzite with like strike and dip-N. $17^{\circ}-23^{\circ} \mathrm{F}$., dip $65^{\circ}$ E. and $90^{\circ}$, on the north, and N. $13^{\circ}-18^{\circ}$ E., dip $90^{\circ}$, on the south. The exposure of quartzite on the north is about 950 feet across the strike and on the south about 3,000 feet. These facts and the jagged structure of the 75-foot high "Bremo Bluff" show that the James here flows through a broad transverse cut in the quartzite and the slate formation west of it. This quartzite is fine grained, muscovitic, and biotitic, with an occasional plate of calcite and a few fragments of plagioclase. It is inter-

\footnotetext{
a See Bibliography, p. $145 . \quad$ O $\quad$ Op. cit., p. 79.

Bull. 275-06-9 


\section{SLATE DEPOSITS AND INDUSTRY OF UNITED STATES.}

bedded here and there with a few inches of slate consisting of muscovite (sericite), quartz, chlorite, and biotite, and containing garnets and lenses of quartz, muscovite, and chlorite, some of which are probably altered garnets. The quartzite also has slate of this character on both sides of it. On the east the quartzite dipping $80^{\circ} \mathrm{E}$., is followed conformably by 40 feet of such slate, then by about 300 feet of micaceous quartzite, followed by an undetermined thickness of ferruginous slate full of pseudo-

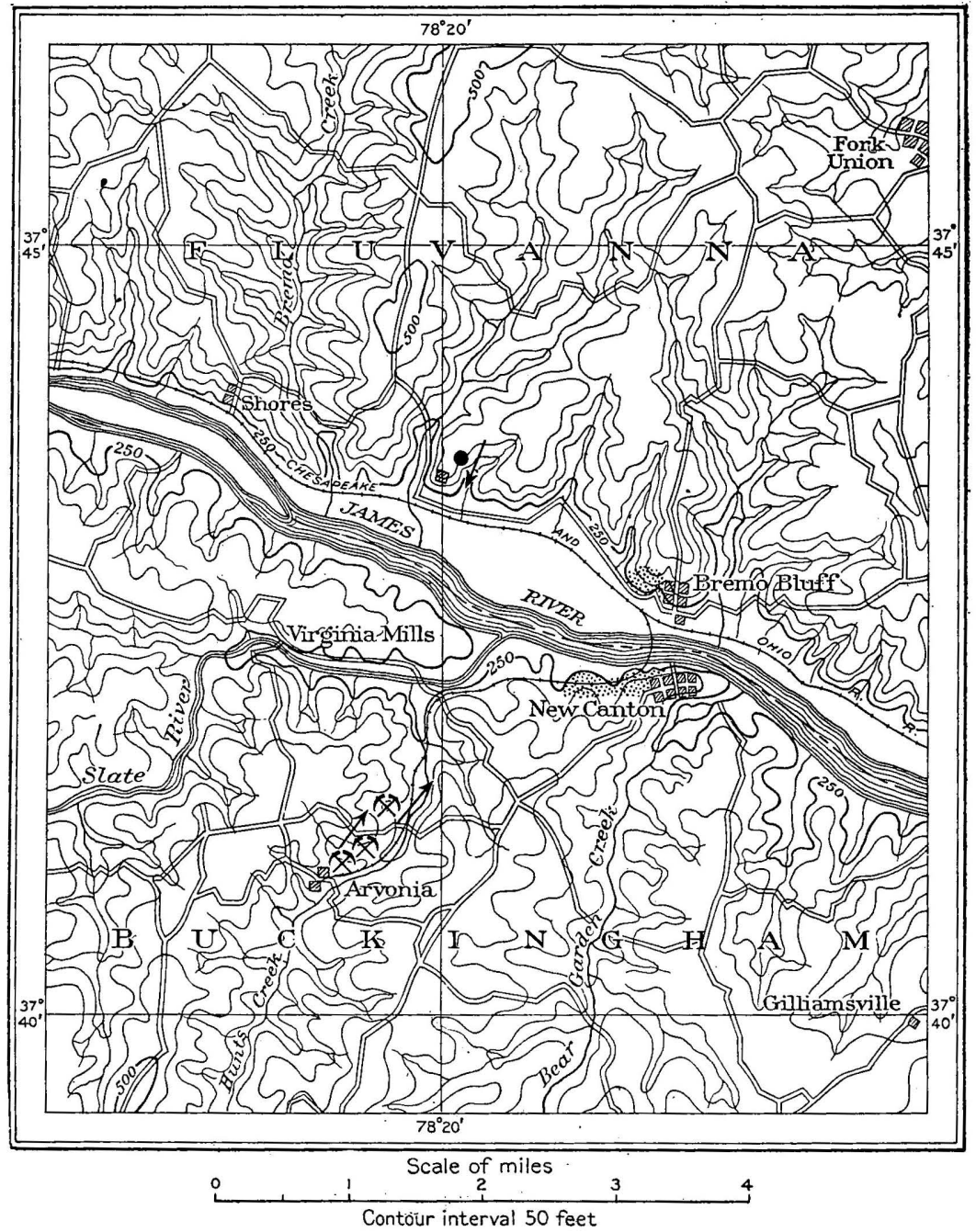

Fig. 12.-Map of slate region in Buckingham and Fluvanna counties, Va. Quarries shown by crossed hammers; slate prospect by round dot; strike of commercial slate by arrows; quartzite areas by fine dots.

morphs or crystals of mica (muscovite?) $1 \frac{1}{2}$ millimeters across, the plates of which lie across the foliation of the rock. This slate was originally bluish gray, but weathers a hematite red.

The general structure of the belt in which the commercial slate beds lie, judging from the railroad cuttings between New Canton and Slate River, appears to consist of minor folds. It is traversed by numerous dikes of olivine basalt, ranging from a 
few inches to 12 feet in thickness (plagioclase, olivine, magnetite, augite), weathering in conchoidal masses with a yellowish-brown surface. The formation is bounded on the east by the quartzite cut by the James River. If this quartzite be a westwardly overturned syncline, it would overlie the slate; if an anticline of like character, it would underlie the slate, in either case in apparent conformity. On the west of the formation at Virginia Mills there are chloritic, sericitic, quartzose, and feldspathic schists striking N. $25^{\circ} \mathrm{E}$. and dipping $90^{\circ}$, crossed diagonally by a small basaltic dike, also certain bright-red weathering chloritic, quartzose, and feldspathic schists, possibly the same as the above, but both of uncertain age.

The commercial slate itself appears to occupy a belt two-fifths of a mile wide along Hunts Creek, which is a southern tributary of Slate River. At Arvonia its course is N. $35^{\circ}$ E., roughly like that of Hunts Creek, which meanders through it; but on the north side of the James, $3 \frac{1}{2}$ miles north-northeast of Arvonia, the strike of the slate is N. $20^{\circ}$ E., like that of the quartzite at Bremo Bluff. There appears thus to be a bend in the slate beds between Arvonia and the north side of the James. The discovery of certain crinoids and more recently of brachiopods, trilobites, etc., in the quarried slate at Arvonia shows it to be of Ordovician age. " Mr. E. O. Ulich, to whom recent collections of these fossils were referred, determines them as unquestionably of Upper Ordovician age, but he finds that the fossils are of such strange types that it will require a very critical study to determine whether the beds are to be correlated with the Mohawkian or with the Cincinnatian formations. The dikes are probably of Mesozoic age.

A,vonia.-The quarries near Arvonia are scattered along the sides of Hunts Creek for a mile northeast of that place. The principal quarries in operation in May, 1904, were the "Old or Big" quarry and the "Middle" quarry of the John R. Williams Slate Company, and the Fontaine quarry of A. L. Pitts. Several others were just being opened or were temporarily abandoned.

The "Big quarry" measures 300 feet along the cleavage, 200 across it, and 125 in depth. Bedding and cleavage are identical, striking N. $37^{\circ}$ E., dipping $86^{\circ} \mathrm{SE}$. There are vertical dip joints striking about northwest, strike joints northeast, southwest, dipping $75^{\circ}-80^{\circ} \mathrm{SE}$., also two sets of diagonal joints, one dipping $30^{\circ} \mathrm{E}$. and the other $55^{\circ} \mathrm{W}$. The latter system has a "post" 5 feet thick full of shear zones. There are also gently undulating "flat joints," to which the grain is parallel. Quartz veins in this quarry contain calcite, chlorite, and biotite.

The "Middle quarry" of the same firm is 500 feet along the cleavage, 350 feet across, and in places 350 feet deep. Bedding and cleavage strike N. $33^{\circ}$ E., dip $85^{\circ}$ SE., and are crossed by northwesterly vertical joints. At the south end is a vertical dike of olivine basalt, 12 feet thick, traversing the slate diagonally, with joints parallel to it on both sides and, for a few feet on its north side, with horizontal joints from 4 to 6 inches apart. The quality of the slate is said to be better a little beyond the zone of these joints than it is at a greater distance from the dike. A horizontal joint in this quarry meanders as much as 10 feet from the horizontal in a distance of 50 feet.

The slate from the Williams quarries is a very dark gray, with a slightly greenish hue. To the unaided eye it has a minutely granular crystalline texture and a slightly roughish, but very lustrous, surface. It is slightly graphitic and magnetitic, shows pyrite on the sawn edge, does not effervesce in cold dilute hydrochloric acid, and is very sonorous.

Under the microscope it shows a matrix of minute alternating beds, chiefly of fine muscovite, with coarser ones, chiefly of quartz, the former with a brilliant aggregate polarization, the latter with a faint one. These beds are parallel to the cleavage. The quartz fragments measure up to $0.085 \mathrm{~mm}$. Scattered throughout both the

$a$ See Darton, N. H., Fossils in the "Archean" rocks of central Piedmont, Virginia: Am. Jour. Sci., 3d ser., vol. 44, 1892, pp. 50-52. 


\section{SLATE DEPOSITS AND INDUSTRY OF UNI'TED STATES.}

more micaceous and the more quartzose beds are crystals, lenses, and particles of pyrite, numbering about 25 to each square millimeter and measuring up to $0.09 \mathrm{~mm}$., rarely 0.15 and 0.42 , with their longer axes parallel to the cleavage. These probably include a little magnetite. There are also biotite scales transverse to the cleavage, about 22 per square millimeter, and measuring up to 0.12 , rarely $0.2 \mathrm{~mm}$. Almost, if not quite, as abundant are plates and rhombs of carbonate. There are occasional scales of chlorite interleaved with muscovite, a few grains of plagioclase feldspar 0.047 $\mathrm{mm}$., rarely one of zircon, some tourmaline prisms $0.014 \mathrm{~mm}$. long, much extremely fine graphitic (or carbonaceous?) material, a few particles of hematite, and some rutile needles. Sections parallel to the cleavage are unusually brilliant in polarized light, owing to the abundance of quartz, biotite, and carbonate.

The chief constituents of this slate, arranged in descending order of abundance, appear to be muscovite and sericite, quartz, biotite, carbonate, graphite (or carbonaceous matter), pyrite, chlorite, magnetite, with accessory plagioclase, zircon, hematite, tourmaline, and rutile.

The Fontaine quarry of A. L. Pitts has a length of 300 feet along the cleavage, a width of 200 , and a depth of about 100 . Bedding and cleavage strike N. $34^{\circ}$ E., dip $80^{\circ} \mathrm{SE}$. The quartz veins also contain calcite.

The slate from this quarry is very dark gray with a greenish hue, and to the unaided eye has a granular sparkling crystalline texture and a roughish, but very lustrous, cleavage surface. It is slightly graphitic (or carbonaceous). The sawn edge shows pyrite. It contains rare particles of magnetite, does not effervesce in cold dilute hydrochloric acid, and is very sonorous.

Under the microscope the Fontaine quarry slate shows alternating bedlets of fine, more muscovitic, and coarser, more quartzose, material, the former having a brilliant aggregate polarization. Much of the mica is in the form of muscovite rather than sericite, particularly in the quartzose beds. These beds are parallel to the cleavage. Quartz fragments abundant, measuring up to 0.09 and $0.12 \mathrm{~mm}$. Most conspicuous scales of biotite lie across the cleavage, usually up to 0.2 by $0.09 \mathrm{~mm}$. and averaging about 10 per square millimeter. Lenses and crystals of pyrite, often surrounded by secondary quartz, about 60 per square millimeter and measuring up to 0.076 by 0.03 , rarely 0.34 by $0.03 \mathrm{~mm}$., with their longer axes in the cleavage. A few scales of chlorite, interleaved with muscovite, lying across the cleavage and up to $0.3 \mathrm{~mm}$. Some carbonate in the coarser bedlets, occasionally with inclusions of an opaque mineral (graphite, pyrite, or magnetite). Much graphitic (or carbonaceous) matter i.l very minute particles. Some hematite and a few crystals of tourmaline, 0.02 by $0.006 \mathrm{~mm}$.

The chief constituents of this slate, arranged in descending order of abundance, appear to be muscovite and sericite, quartz, biotite, carbonate, pyrite, graphite (or carbonaceous matter), chlorite, magnetite, hematite, with accessory tourmaline.

A specimen from an exceptional bed in the same quarry shows a wrinkled surface from the abundance of biotite lenses measuring a half inch in length by a twentieth in width at the center. George H. Williams $a$ found the joint faces at the old Roberts quarry covered with pyrite and crystals $1 \mathrm{~mm}$. long, which when analyzed proved to be $\mathrm{TiO}_{2}$ and which he determined optically as anatase.

Although the Arvonia slates, as shown by the above determinations, contain some carbonate, that does not include any appreciable amount of ferrous carbonate, for some of these slates put on the old Richmond theater over sixty years ago, when removed within the last three years, did not show any discoloration whatever, and some have been on buildings near the quarries over a century without losing any of their blackness. Their highly crystalline character also implies strength and durability.

$x$ Anatase from the Arvon slate quarries, Buckingham County, Va.: Am. Jour. Sci., 3d ser., vol. 42, 1891, p. 431 . 
The results of Professor Merriman's recent tests of slate from the Williams and Pitt quarries are given on page 123 .

Bremo.- Slate has been prospected on the estate of the late Dr. Casey Charles Cocke, 2 miles west-northwest of Bremo Bluff, in Fluvanna County. It occurs in the ravine east of the house and also on the hill northeast of it. The strike is N. $18^{\circ}-23^{\circ}$ E., dip nearly $90^{\circ}$. A little northwest of the house is a dike of olivine basalt 5 to 10 feet wide. The following results are from an examination of specimens obtained within a few feet of the surface which, therefore, belong to the "top."

This slate is dark gray, but its lightness of shade is in part the result of weathering. It will prove to be darker below the zone of weathering. To the unaided eye it has a fine texture with a somewhat fine and very lustrous cleavage surface more or less dotted with minute lenses or crystals. It is slightly graphitic, but not magnetitic, shows pyrite on sawn edges, does not effervesce in cold dilute hydrochloric acid, has an argillaceous odor, is sonorous and very fissile. The slate from one of the openings has exceedingly minute veins of muscovite.

Under the microscope the Bremo slate shows a matrix of muscovite (sericite), with a brilliant aggregate polarization.

There are abundant quartz grains up to 0.09 by 0.03 and $0.13 \mathrm{~mm}$. long, the larger ones surrounded by secondary quartz radiating along the cleavage; about 50 lenses and crystals of pyrite per square millimeter, measuring up to 0.09 by 0.02 (exceptionally the lenses are $1.5 \mathrm{~mm}$. long), with their longer axes in the cleavage. There are also square and rhombic spaces lined with secondary quartz, measuring up to $0.6 \mathrm{~mm}$., left by the dissolution of cubes or distorted cubes of pyrite. In some specimens there are 65 such cavities to the square inch, in others none. There are lenses up to 0.56 by $0.11 \mathrm{~mm}$., consisting of quartz and muscovite or of these and chlorite and pyrite, or of chlorite and muscovite, the folia of muscovite and chlorite lying across the cleavage; also muscovite scales up to 0.09 by $0.02 \mathrm{~mm}$. Throughout the matrix much dark-gray material occurs in exceedingly fine dots (graphite?). There are also some dots of hematite. Rutile needles are not very plentiful up to $0.01 \mathrm{~mm}$. long; also a number of very irregular particles of rutile up to $0.05 \mathrm{~mm}$., consisting of a network of crystals ("sagerite twinning") forming angles of $120^{\circ}$ and $60^{\circ}$. A few fragments of zircon, an occasional crystal of dark tourmaline up to 0.05 by $0.02 \mathrm{~mm}$. rare flakes of biotite, no carbonate.

The chief constituents of Bremo slate, arranged in descending order of abundance, appear to be muscovite, quartz, pyrite, kaolin, chlorite, graphite (or carbonaceous material), rutile, with accessory tourmaline, zircon, biotite, and hematite.

This slate differs from the Arvonia slate in its finer texture, probable slightly lighter shade, and slightly higher percentage of pyrite. It has less biotite and, at least in the "top," no carbonate.

Core drilling or excavation deep enough to penetrate the "top" is amply warranted by the above determinations. $a$

Snowden, Amherst County.-The Snowden slate deposit is on the southeast side of the axis of the Blue Ridge, north of the cut through which the James River flows. It is situated about 18 miles north-north west of Lynchburg. (See map, fig. 13.) The slate crops out in a longitudinal valley with Rocky Row Mountain on its northwest side and a spur of Big Piney Mountain on its southeast side. It strikes N. $65^{\circ} \mathrm{E}$. and has quartzite southeast of it. The general structure and the areal relations of the slate have not yet been exhaustively investigated. $b$

The only quarry in operation in 1904 was that known as the Williams Brothers slate quarry, on the property of the Virginia Slate Mining Company, which lies 3

$a$ Slate outcrops on this property were referred to by J. L. Campbell, Tenth Census, special report on building stones, vol. 10, 1884, p. 181 .

b See Campbell, Bibliography, p. 143, also Geology of the Blue Ridge, near Balcony Falls, Va.: Am. Jour. Sci., 3d ser., vol. 28, 1884, pp. 221-223. 


\section{SLATE DEPOSITS AND INDUSTRY OF UNITED STATES.}

miles north-northeast of Snowden station, where Rocky Row Run enters the James River, and about 1,200 feet above it. About 250 feet of slate are exposed with a bedding strike of $\mathrm{N} .65^{\circ} \mathrm{E}$., forming a flat-topped anticline, whose northern limb dips $35^{\circ}$ at the surface, but becomes vertical at the bottom of the quarry, and for a space of a few feet dips steeply south, indicating a possible overturn structure. The cleavage strikes $\mathrm{N} .45^{\circ} \mathrm{E}$., dips southeast at $32^{\circ}$. The bedding forms finely plicated ribbons of quartz and calcite several inches wide on the cleavage surfaces. Joints strike N. $18^{\circ} \mathrm{E}$, $\operatorname{dip} 70^{\circ} \mathrm{W}$., also N. $18^{\circ} \mathrm{W}$, dip $65^{\circ} \mathrm{E}$. The grain makes an angle of from $90^{\circ}$ to $104^{\circ}$ with the bedding and is said to be very marked.

This slate is very dark gray, to the unaided eye has a minutely granular texture, a moderately smooth cleavage surface, with very little luster. It is not graphitic,

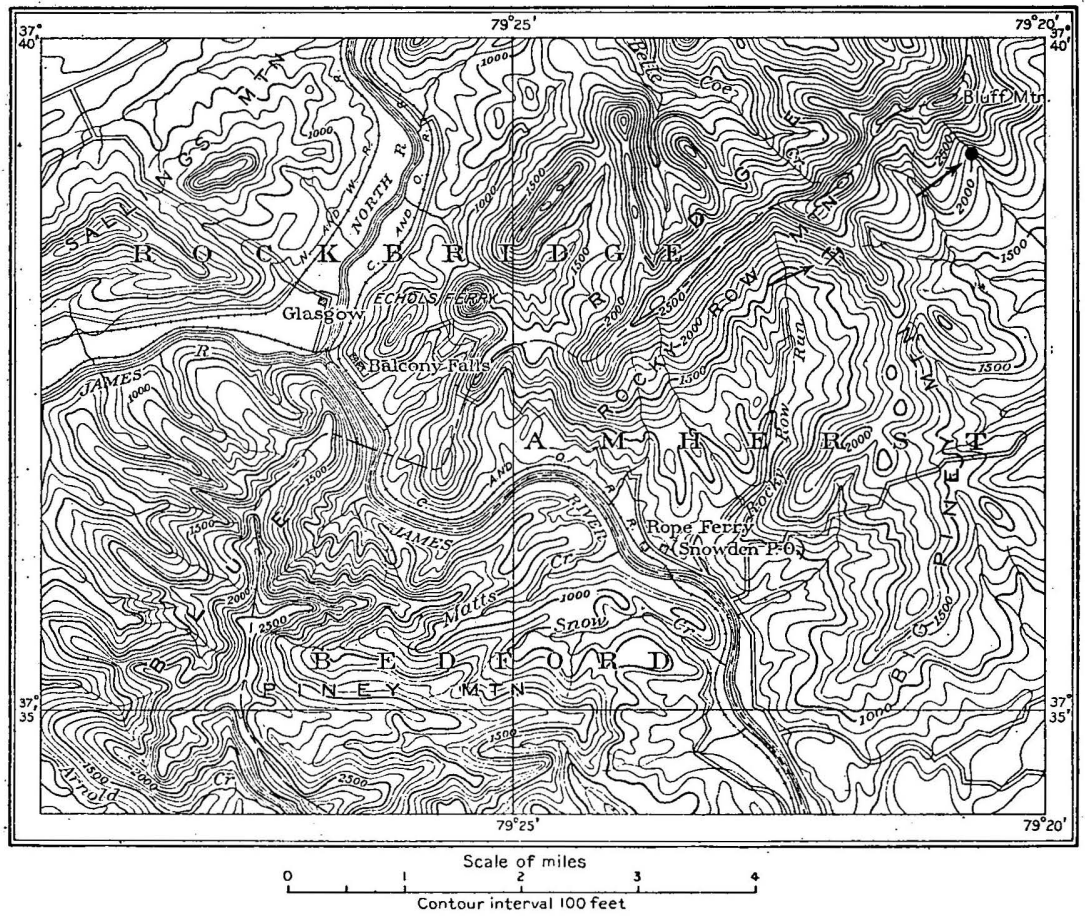

FIf. 13.-Map showing location of Snowden quarries, Amherst County, Va. Quarries shown by crossed hammers; slate prospects by round dots; strike of commereial slate by arrows.

shows no pyrite on sawn edge, has no magnetite, does not effervesce with cold dilute hydrochloric acid, is quite sonorous, has a very slight argillaceous odor and is said not to fade.

Under the microscope it shows a matrix of muscovite (sericite), with aggregate polarization not very brilliant owing partly to the coarseness of many of the other constituents. Quartz fragments measure up to $0.08 \mathrm{~mm}$.; chlorite scales and lenses up to 0.28 in length, rarely 0.42 by $0.2 \mathrm{~mm}$., numbering about 6 per square millimeter; also muscovite scales up to $0.09 \mathrm{~mm}$. ; some carbonate, but in exceedingly minute rhombs and plates; grayish carbonaceous (?) matter; about 55 spherules and pyritohedrons of pyrite per square millimeter, measuring up to $0.005 \mathrm{~mm}$.; abundant rutile needles, and occasional fragments of zircon.

The chief constituents of this slate, arranged in descending order of abundance, 
appear to be muscovite (sericite), quartz, chlorite, kaolin, pyrite, carbonate, rutile, and carbonaceous matter. This is a superior slate, but is less crystalline than that of Arvonia. It is used exclusively for roofing, having been found less well adapted for mill stock.

About $1 \frac{1}{2}$ miles northeast of the Wiłliams Brothers quarry slate was prospected nineteen years ago on the Thompson property. This lies on a small tributary of Otter Creek, which flows into the James $1 \frac{1}{2}$ miles downstream from Snowden. (See fig. 13.) The thickness exposed is 20 feet. Bedding strikes N. $53^{\circ}$ E., dips $20^{\circ} \mathrm{SE}$; cleavage is nearly horizontal. "Joints strike N. $38^{\circ} \mathrm{E}$. and dip $20^{\circ} \mathrm{W}$. This slate closely resembles that of the Williams Brothers quarry both in its external and microscopic characteristics and $i$ 's r onorousness.

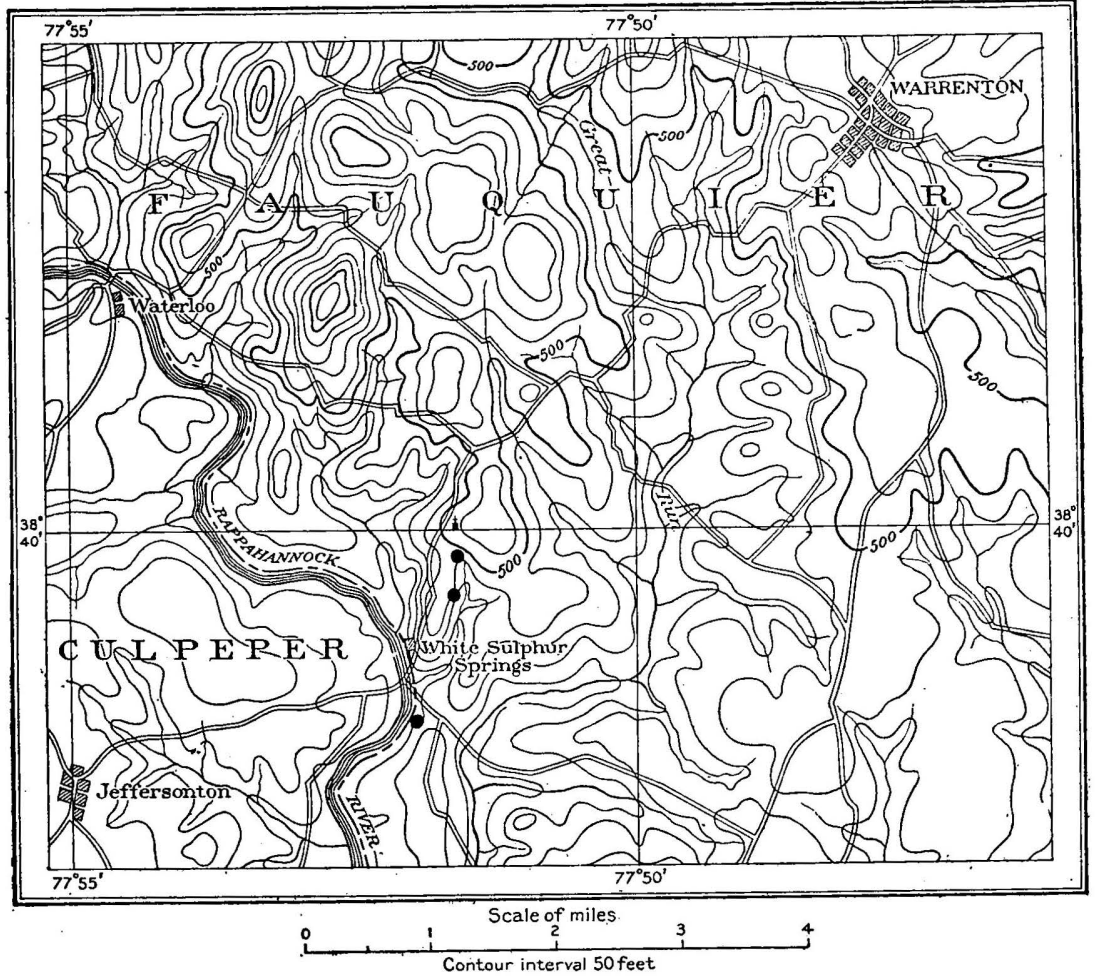

FIG. 14.-Map of slate prospects in Fauquier County, Va. Slate prospects are shown by round dots.

Warrenton, Fauquier County.-There are several prospects in the neighborhood of White Sulphur Springs on the Rappahannock, 6 miles southwest of Warrenton, to which Rogers referred, $a$ from which roofing slate was obtained as early as 1837. (See map, fig. 14.)

The following data afford some indications as to the geological relations: About $1 \frac{1}{4}$ miles south of the Springs and 200 feet east and as far west of the road to Routsville there are outcrops of muscovitic quartzite with grains and pebbles of blue quartz.up to one-fourth inch across. These beds have an apparent east-west strike and a gentle southerly dip. A little north of this quartzite slate crops out and continues northward for 2 miles to near the "colored church." Its cleavage strikes N. $25^{\circ}-30^{\circ} \mathrm{E}$., but the slate three-fourths of a mile south of the Springs, at the river, strikes about 


\section{SLATE DEPOSITS AND INDUSTRY OF UNITED STATES.}

east-west, like the quartzite farther south. Slate is also said to occur at points west of the road from the Springs to the church. The minimum width of this slate belt is half a mile. North of the church is a greenish metamorphic eruptive consisting of actinolite, zoisite, titanite, and sericitized plagioclase. South of the quartzite are greenish schists, possibly of similar origin. Between the church and Warrenton greenish schists also crop out at several points. They are epidotic actinolite schists in places with lenses up to 3 by 2 feet, and stratiform masses of an epidotic rock containing actinolite, titanite, magnetite, chlorite, and quartz.

All these hornblendic and epidotic rocks weather into a bright reddish soil. This slate is thus related to a quartzitic formation, as well as to certain hornblendic and epidotic rocks, which must be regarded as metamorphosed eruptives. ${ }^{\prime}$ The proximity of the slate to these other formations is so close that nothing can be assumed as to its thickness.

Slate has been prospected at three points, indicated by black dots on the map, fig. 14. One is seven-eighths of a mile north-northeast of the Springs, east of road to Warrenton and west of beginning of small brook flowing south into the Rappahannock. Cleavage strikes N. $30^{\circ}$ E., dips $25^{\circ} \mathrm{W}$. The plowed fields on the south show a strip of dark-gray soil, from the weathering of the slate, which measures 125 feet across. The slate is black, and, to the unaided eye, has a coarsish texture, a rough, speckled cleavage surface with little luster. It is very carbonaceous; shows pyrite on sawn edges, and has about 220 cubes and lenses of pyrite to the square inch, measuring one-fiftieth of an inch and under; no magnetite; nor effervesence with cold dilute hydrochloric acid. It has an argillaceous odor.

Under the microscope this shows no aggregate polarization, but a coarse cleavage, the matrix mainly of carbonaceous matter and quartz fragments with a little muscovite. The quartz grains measure from 0.009 to $0.3 \mathrm{~mm}$; quite a number of plagioclase feldspar fragments up to $0.2 \mathrm{~mm}$. long. Lenses and cubes of pyrite coated with quartz, about 5 per square millimeter; a few scales of chlorite; rare fragments 'of zircon. No carbonate or rutile detected.

The chief constituents of this slate, arranged in descending order of abundance, appear to be: Carbonaceous matter, quartz, muscovite, feldspar, pyrite, and chlorite. This is a clay-slate.

At the locality about a half mile northeast of the Springs the cleavage strikes N. $25^{\circ} \mathrm{E}$., dips $20^{\circ} \mathrm{W}$., bedding probably N. $12^{\circ} \mathrm{W}$. Strike joints strike N. $15^{\circ} \mathrm{E}$., $\operatorname{dip} 90^{\circ}$; dip joints $\mathrm{N}$. $75^{\circ} \mathrm{W}$, dip $90^{\circ}$, but variable. The slate is here covered with 2 feet of black clay, and these by 3 feet of brownish ye!low clay, both of which still show a lamination parallel to the cleavage of the underlying slate, and therefore represent different stages in the decomposition of the slate.

This slate is bluish black, to the unaided eye has a moderately fine texture and cleavage surface with very few lenses of pyrite and but little luster. It is very carbonaceous, shows pyrite on sawn edge, has no magnetite, no effervescence in cold dilute hydrochloric acid, is sonorous, and has an argillaceous odor.

Under the microscope this has a matrix of muscovite (sericite) with distinct aggregate polarization but abundant irregular quartz grains from 0.009 to $0.37 \mathrm{~mm}$; also some lenses of secondary quartz, much carbonaceous matter, a few lenses of pyrite up to $0.14 \mathrm{~mm}$., passing into limonite, a few grains of plagioclase feldspar. No carbonate or rutile detected.

The chief constituents of this slate, arranged in descending order of abundance, appear to be muscovite (sericite), quartz, carbonaceous matter, pyrite. Recent excavations are said to show a larger amount of pyrite at a depth of 20 feet than the specimen above described indicates. This is a mica slate.

The third locality is about a half mile south of the Springs, on the east bank of the Rappahannock. About 40 feet of "slate" are exposed in a small cliff. The strike of

$a$ Rogers, op. cit., refers to the epidotic ones. 
cleavage and bedding (?) ranges from N. $80^{\circ}$ E. to N. $85^{\circ}$ W., dipping south at angles varying from $12^{\circ}$ to $15^{\circ}$.

The slate is bluish black, has a coarse crystalline texture, and, as accurately described by Rogers, ${ }^{a}$ a knotty, wrinkly surface. This is due to the presence of cubical and lenticular cavities once occupied by pyrite but now partially filled with quartz and graphite. These measure from one to three-fiftieths of an inch and number from 12 to 20 per square inch. The surface has very little luster. The slate is carbonaceous or graphitic, shows pyrite on the sawn edge, has very little magnetite, in places scales of a micaceous mineral up to one twenty-fifth of an inch, does not effervesce in cold dilute hydrochloric acid, has an argillaceous odor, and is very sonorous.

Under the microscope it shows a matrix of carbonaceous or graphitic material, quartz, and muscovite. As the first two predominate the aggregate polarization is quite faint. The cleavage is serpentine, owing to the many large quartz grains (up to 0.14 millimeter) and the cubes and lenses or distorted cubes of pyrite already referred to, most of which seem to be partial psendomorphs of quartz and graphite after pyrite, the remaining pyrite having been oxidlized and dissolved. There are some plagioclase feldspar grains almost as large as the quartz grains, with graphite inclusions parallel to the multiple twinning. There are veinlets of quartz and lenses of secondary quartz usually about or on either side of the cubes and lenses of pyrite; rare grains of zircon. No carbonate or rutile detected.

The chief constituents of this, arranged in descending order of abundance, appear to becarbonaceous matter and graphite, quart $\%$, muscovite, kaolin, pyrite, and feldspar. It seems to be more metamorphic than that of the other localities, yet less micaceous. This is properly a graphite-quartz-muscovite-schist, or in process of becoming such. A piece of this "slate" a half inch thick from the roof of one of the brick outbuildings at the White Sulphur Springs, where it was placed at least sixty-eight years ago, does not show any decomposition, but in places has a little limonite coating.

The pyritiferons character of all these Fauquier County slate prospects and the sulphurous character of the springs are probably intimately related. Such springs are common in the vicinity of pyritiferous shale and obtain their sulphur from the decomposition of the pyrite by surface water. The indications from the openings and the microscopic examinations are not sufficiently promising to warrant investments.

The principal features of Virginia slate, as given in the foregoing descriptions, will be found in tabular form opposite page 124 .

\section{WEST VIRGINIA.}

\section{By T. Nelson Dale.}

This recently prospected slate district lies near Martinsburg, in Berkeley County, within the geological belt designated in the Harpers Ferry folio of the United States Geological Survey as "Martinshurg shale." Brief preliminary notices of it have appeared in Bulletin No. 213 (p. 363) and again in Bulletin No. 260 (p. 538). This belt lies about 13 miles west of the Blue Ridge and mostly on the western side of Opequon Creek, a small tributary of the Potomac. It measures at least 14 miles in length from north-northeast to sonth-southwest and from 2 to 3 miles in width. The accompanying map (fig. 15) shows the geological relations and the principal outcrops. This shale and clay-slate formation, estimated at from 700 to 1,000 feet in thickness, is of Ordovician age and overlies the Cambro-Ordovician "Shenandoah limestone" in a series of folds represented in the folio as overturned to the west. The rock is generally a dark-grayish shale, weathering into a yellowish or white clay, known locally as "soapstone." At several points, usually near the Opequon 


\section{0}

or its tributary "runs," where the mass has been denuded of its weathered zone, it has a well-marked easterly dipping (exceptionally westerly) slaty cleavage crossing

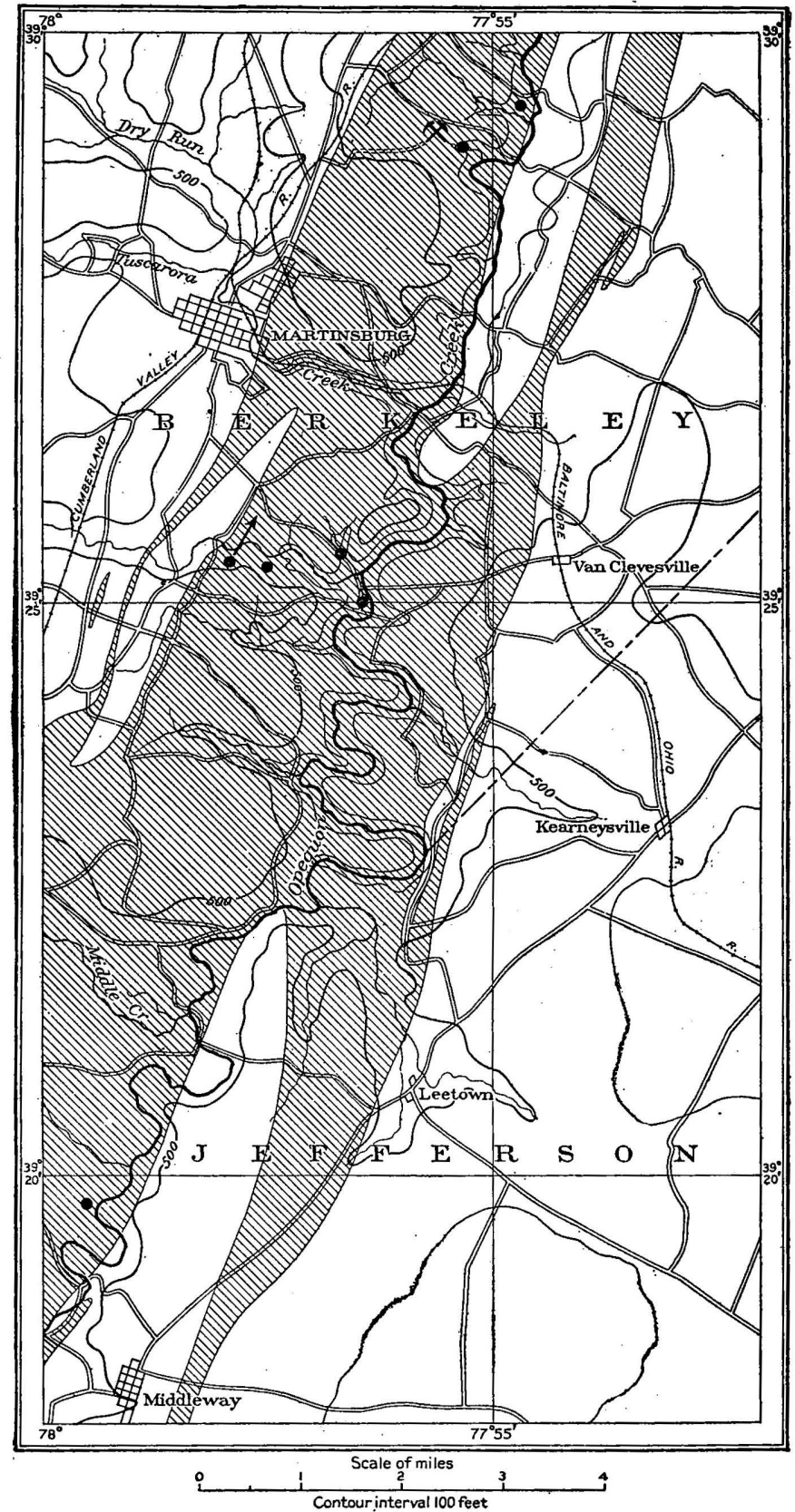

Frg. 15.-Map of slate region about Martinsburg, W. Va. (From Geologic Folio No. 10, Harpers Ferry, U. S. Geol. Survey.) Shading represents area underlain by Martinsburg shale. Slate quarry is shown by crossed hammers; slate prospects by round dots; strike of commercial slate by arrow.

the bedding at various angles, and pieces, when struck with a hammer, give the typical ring of a slate. The slatiness of the formation is, however, inconstant. 
The only quarry yet opened is that of the Shenandoah Slate Company, about 3 miles northeast of Martinsburg, near a small run flowing into the Opequon. When visited in May, 1904, the quarry measured about 100 feet along the strike, 70 feet. across it, and 75 feet in depth, of which the "top" took up 25 feet. The bedding strikes N. $25^{\circ} \mathrm{E}$., dips about $15^{\circ} \mathrm{E}$. The cleavage, with the same strike, dips $75^{\circ} \mathrm{E}$. There are joints striking with the cleavage and dipping $35^{\circ}$ E., dip joints striking $\mathrm{N}$. $50^{\circ} \mathrm{W}$., dipping $90^{\circ}$. The beds are small and are separated by darker ribbons. The thickest bed exposed measured 3 feet 6 inches. A diamond drill core from down to 40 feet below the bottom of the quarry shows several 3-foot beds.

The slate is black, with a slightly brownish hue. The texture is somewhat fine and the cleavage surface roughish without any luster whatever. The material is carbonaceous rather than graphitic, contains a little magnetite, shows pyrite on the sawn edge, effervesces with cold dilute hydrochloric acid, but less in the ribbon, is somewhat sonorous, and has an argillaceous odor. Under the microscope it shows a matrix consisting of carbonate and carbonaceous matter, and therefore without aggregate polarization, but a cleavage consisting in the parallel arrangement of the (arbonate and carbonaceous matter in alternating bands. A very carbonaceous bed (ribbon) crosses the cleavage at an angle of $36^{\circ}$. There are abundant angular quartz grains up to 0.05 millimeter; scales of chlorite interleaved with muscovite, and some of muscovite only; spherules of pyrite up to 0.01 millimeter, numbering about 240 per square millimeter. Rutile not observed. The amount of carbonate differs in different beds. It may be so abundant as to obscure completely the sericitic matrix. Some of the sections parallel to the cleavage show almost as much muscovite as carbonate and, curiously, a faint aggregate polarization parallel to the bedding or the grain.

The constituents of the Shenandoah Slate Company's slate, arranged in descending order of abundance, appear to be carbonate, muscovite (in places almost equal in amount to carbonate), quartz, kaolin, pyrite, carbonaceous matter, chlorite, magnetite. This is a clay-slate. The amount of $\mathrm{CO}_{2}$ (carbon dioxide) in this slate was determined by Mr. George Steiger, chemist of the United States Geological Survey, at 1.94 per cent.

An analysis of slate from this quarry, made for the company by Dr. W. C. Tilden, of Washington, shows $\mathrm{SiO}_{2}, 62.71 ; \mathrm{Al}_{2} \mathrm{O}_{3}, 19.40$, and $\mathrm{CaO}, 1.11$ per cent. It is proposed to use the product of this quarry for mill stock, for which it seems better adapted than for roofing.

The following prospects were noted: One 2 miles south of Martinsburg, on John Rowe's land, where an opening 30 by 20 feet has been made. Bedding strikes N. $32^{\circ} \mathrm{E}$., dips $60^{\circ}-65^{\circ}$ E.; cleavage strikes N. $23^{\circ}$ E., dips $80^{\circ}$ E. A 3 -foot bed is in sight. Another opening has been made on the Opequon, on Light's land, a half mile southsoutheast of Bedington (a little north of the north limit of map). Bedding and cleavage strike $\mathrm{N} .20^{\circ} \mathrm{E}$., the former dipping $30^{\circ} \mathrm{E}$., the latter $55^{\circ} \mathrm{E}$. A 3-foot bed is in sight. Under the microscope this shows a faint aggregate polarization, fragments of feldspar, and rutile needles. At an opening on T. F. Bowers's farm, about 4 miles northeast of Martinsburg, the cleavage strikes N. $27^{\circ}$ E._and dips $73^{\circ} \mathrm{W}$., but bedding dips east. Under the microscope this also shows a faint aggregate polarization, but carbonate is unusually abundant and evidently obscures the cleavage. In the brook on John Shedd's farm, $2 \frac{1}{2}$ miles south-southeast of Martinsburg, the cleavage strikes $\mathrm{N} .20^{\circ} \mathrm{E}$. Under the microscope this shows a slight aggregate polarization and but little carbonate. Clay-slate has also been found on the McKown and Busey farm, 2 miles N. $10^{\circ} \mathrm{W}$. from Middleway, in brook $2 \frac{1}{2}$ miles southeast of Martinsburg, and also on land of J. W. Snyder on the Opequon, 3 miles southeast of Martinsburg, and it will be found in many other places.

Although the proportions of carbonate and muscovite vary in these slates, none of them show a complete sericitization of the matrix. They are all clay-slates. The material can therefore hardly possess sufficient fissility or prove sufficiently strong or elastic to compete with mica-slates for roofing purposes. Furthermore, the amount of carbonate shown by the microscope, as well as the mode of weathering by the 
outcrops, indicates its probable discoloration on prolonged exposure, so that it belongs in the "fading" group of clay-slates. But these characteristics do not affect its serviceableness for indoor purposes.

The principal features of these West Virginia slates are stated in tabular form opposite page 124 .

\section{WERRIMAN'S RECENT TESTS OF CERTAIN MAINE, NEW YORK, PENNSYLVANIA, VERMONT, AND VIRGINIA SLATES.}

In view of the incompleteness of published data as to the physical properties of American roofing slates, Doctor Day, chief of the division of mineral statistics of the United States Geological Survey, induced Prof. Mansfield Merriman, of Lehigh University, to apply his well-known methods of testing roofing slates to typical specimens from nine important localities. The specimens were obtained from various firms and forwarded to him. Professor Merriman's communication to Doctor Day, containing his full report on the results of these tests, follows:

The following is a report of the results of the tests of thirty-three specimens of roofing siate received at our laboratory from May 6 to May 13, 1905. The tests have been made according to the methods described in my paper on "The strength and weathering qualities of roofing slates," in Transactions of American Society of Civil Engineers, September, 1892.

All the specimens were 12 by 24 inches in size. The following is a statement of the marks placed upon them and of their mean thicknesses:

C1, C2, C3, C4 designate four blue slates from the Chapman Slate Company, Chapman Quarries, Pa., the mean thicknesses being $0.228,0.204,0.216,0.222$ inches, respectively.

W1, W2, W3, W4 designate four blue slates from the Williams Slate Company, Arvonia, Va., the mean thicknesses being $0.202,0.195,0.206,0.263$ inches, respectively.

P1, P2, P3, P4 designate four blue slates from A. L. Pitts, Arvonia, Va., the mean thicknesses being $0.232,0.200,0.204,0.194$ inches, respectively.

B1, B2, B3 designate three blue slates from the Merrill Brownville Slate Company, Brownville, Me., the mean thicknesses being $0.220,0.195,0.210$ inches, respectively. A fourth piece sent by this firm was accidently broken.

Mo1, Mo2, Mo3, Mo4 designate four blue slates from Monson Consolidated Slate Company, Monson, Me., their mean thicknesses being $0.238,0.227,0.237,0.225$ inches, respectively.

V1, V2 designate two green slates from Vermont Unfading Green Slate Company, Fair Haven, Vt., their mean thicknesses being $0.222,0.262$ inches, respectively. Two other pieces sent by this firm were found broken in the package.

R1, R2, R3, R4 designate four green slates from Rising \& Nelson Slate Company, West Pawlet, Vt., their mean thicknesses being $0.260,0.167,0.224,0.213$ inches, respectively.

M5, M6, M7, M8 designate four green slates from Mathews Consolidated Slate Company, Boston, Mass., their mean thicknesses being $0.194,0.222,0.187,0.205$ inches, respectively. The labels on these slates were marked "Quarry N. E."

M1, M2, M3, M4 designate four red slates from Mathews Consolidated Slate Company, Boston, Mass., their mean thicknesses being $0.190,0.180,0.174,0.186$ inches, respectively. The labels on these slates were marked "Quarry E."

The following table gives the results of the tests of the above 33 specimens for strength, toughness, density, softness, porosity, and corrodibility, and also the means for each of the nine different kinds of slate:

\begin{tabular}{|c|c|c|c|c|c|c|c|}
\hline Color and firm. & $\begin{array}{l}\text { Mark on } \\
\text { speci- } \\
\text { men. }\end{array}$ & $\begin{array}{l}\text { Strength- } \\
\text { modulus of } \\
\text { rupture in } \\
\text { pounds per } \\
\text { square } \\
\text { inch. }\end{array}$ & $\begin{array}{l}\text { Tough- } \\
\text { ness-ul- } \\
\text { timate } \\
\text { deflec- } \\
\text { tion in } \\
\text { inches on } \\
\text { supports } \\
22 \text { inches } \\
\text { apart. }\end{array}$ & $\begin{array}{l}\text { Density- } \\
\text { specific } \\
\text { gravity. }\end{array}$ & \begin{tabular}{|} 
Softness- \\
amount in \\
grams \\
abraded \\
by 50 turns \\
of a small \\
grind-- \\
stone.
\end{tabular} & $\begin{array}{l}\text { Porosity- } \\
\text { per cent of } \\
\text { water ab. } \\
\text { sorbed in } \\
24 \text { hours. }\end{array}$ & $\begin{array}{l}\text { Corro- } \\
\text { dibility- } \\
\text { per cent } \\
\text { of weight } \\
\text { lost in } \\
\text { acid solu- } \\
\text { tion in } 63 \\
\text { hours. }\end{array}$ \\
\hline \multirow[t]{5}{*}{ Blue; $a$ Chapman Slate Co. } & C1 $1 \ldots . .$. & 8,410 & 0.21 & 2. 775 & 0.171 & 0.221 & 0.336 \\
\hline & $\mathrm{C} 2 \ldots$ & 12,490 & .24 & 2. 780 & .218 & .290 & .301 \\
\hline & C3 $\ldots . .$. & 7,420 & .16 & 2. 734 & .234 & .150 & .560 \\
\hline & $\mathrm{C} 4 \ldots \ldots$ & 9,540 & .24 & 2.766 & .213 & .263 & .334 \\
\hline & Means & 9,460 & .212 & 2. 764 & .208 & .231 & .383 \\
\hline
\end{tabular}

a Designated as very dark gray in table facing page 124. 


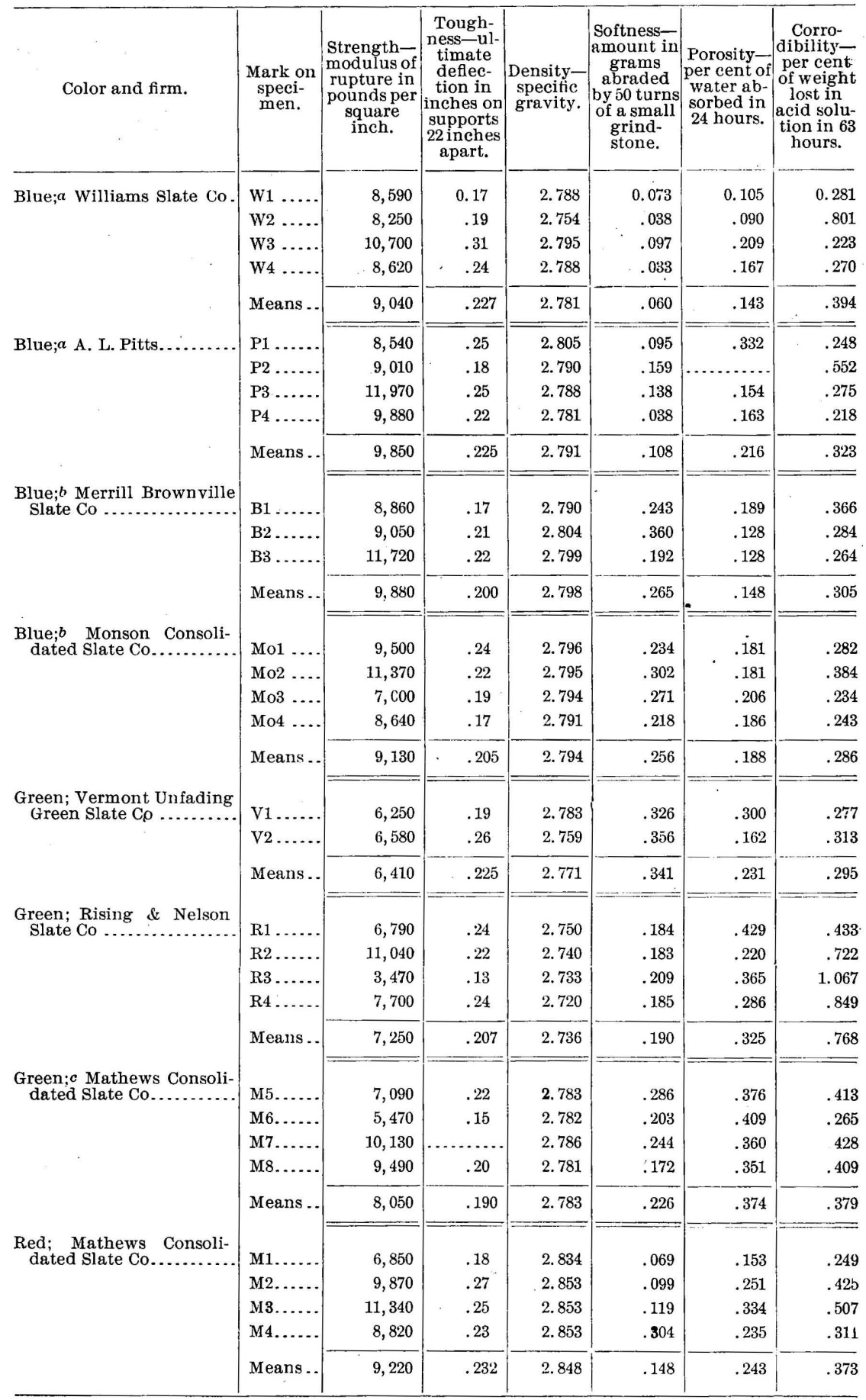

a Designated as very dark greenish gray in table facing page 124 . $b$ Designated as very dark gray in table facing paye 124 . $c$ Designated as bright green in table facing page 124. 
The given results, with the exception of those for softness, may be compared with the results for Bangor, Pen Argyl, Lehigh, and Peach Bottom slates, given in my papers published in Transactions of American Society of Civil Engineers for September, 1892, and December, 1894, and in stone for July, 1898. The results above given for softness are comparable with each other, but can not be compared with those in the papers cited; this is due to the circumstance that the former grindstone has been destroyed by fire and that the one selected to replace it has a much smaller abrading capacity.

South Bethlehem, PA., July 21, 1905. Mansfield Merriman.

\section{COMPARATIVE CHARACTERISTICS OF SLATES.}

The following table shows the principal mineralogical, chemical, and physical characteristics of 38 kinds of slate described by the writer in this bulletin as far as these manifestly bear upon their economic value. These slates are from Arkansas, California, Maine, Maryland, New York, Pennsylvania, Vermont, Virginia, and West Virginia. For full particulars and for scientific details the descriptions should be consulted, by reference to the pages given in the first column. The columns headed "strength" and "toughness" refer to the tests by Merriman, whose methods of experimentation are described on page 47. Microscopic texture refers primarily to the matrix or body of the slate. By "crystalline" is meant that the matrix consists of interlacing and overlapping scales and fibers of muscovite and is, therefore, a micaslate or technically a phyllite-slate, although it may inclose unaltered particles of sedimentary origin. Such a slate should have, other things being equal, greater elasticity (toughness) and strength than one in which there is no such texture, or in which it is only incipient. The fineness or coarseness of this crystalline texture probably has a bearing upon the strength and toughness of the slate, but physical data are not sufficient to show this. The coarse-textured Peach Bottom slates, which really approach a mica schist, are the strongest of the twelve kinds of American slates tested, but they are less flexible than all the other kinds tested. In the grade of fissility 1 signifies a perfect slaty cleavage, 4 a very imperfect one. The column of chief mineral constituents includes only the four or five principal ones seen under the microscope, or whose presence has been otherwise determined, and these are given in the descending order of their probable abundance.

To these comparative data should be added the results of a few tests not easily tabulated.

Merriman's later corrosion tests showing the following percentages of loss in weight after immersion in acid solution for 360 hours: Pennsylvania slates, 1.68 to 2.76; Peach Bottom, 1.11 to 1.29; red of New York and Vermont, 0.25. During this test the Pennsylvania slates become a grayish white, some of the Peach Bottom slates change but slightly, others are almost unaffected; the red slates likewise remain almost unaffected. $a$

E. H. S. Bailey's tests of porosity give these indices of porosity: "Hard Vein" Pennsylvania Chapman, 0.11-0.14; Daniels quarry, 0.14; Belfast quarry, 0.25; red of New York and Vermont, 0.21.b

J. F. Williams's tests of the compression of columns of slate 10 inches long by an inch in section with the cleavage vertical, show that the purplish of the unfading green series of Vermont stands 20,000 pounds; the unfading green, 16,020 pounds, and the red of New York and Vermont, 17,730 pounds. $c$

The following results of various tests of Maine (Monson) slate made at the United States Arsenal at Watertown, Mass., were republished from the War Department reports in the Twentieth Annual Report of the United States Geological Survey, Part VI (continued), 1899, p. 395: 


\begin{tabular}{|c|c|c|c|c|c|c|c|c|c|c|c|c|c|c|}
\hline $\begin{array}{l}\text { Described } \\
\text { on page- }\end{array}$ & State. & Locality, quarry, bed. & Color. & Cleavage surface. & Luster. & Magnetite. & Microscopic texture. & 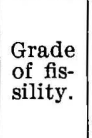 & Chief minerals. $a$ & Carbonate. & $\begin{array}{c}\text { Lime } \\
\text { hy } \\
\text { anly. } \\
\text { sis. }\end{array}$ & 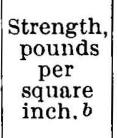 & $\underset{\substack{\text { Tough } \\
\text { ness. } .}}{\operatorname{Tos}}$ & Remarks. \\
\hline 53 & Arkansas. & Mena, Polk County....... & Black........ & Remarkably fine. & Slight... & Some ... & $\begin{array}{l}\text { Crystalline, extrem } \\
\text { fna }\end{array}$ & 1 & Muscovi., carbon, quartz, pyrite ...... & None .... & & & & 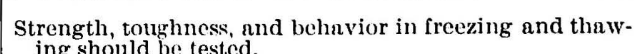 \\
\hline 54 & do ... & 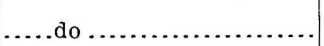 & Dark reddish . & Roughish, speckled. & Almost no & Very little. & $\begin{array}{l}\text { mine, no } \\
\text { Crystallin }\end{array}$ & 3 & Muscov., hematite, kaolin, quartz ... & ....do. & & & & \\
\hline 54 & .... .. & $\begin{array}{l}\text { Mammoth Red and Lost } \\
\text { Hannah Polk County. }\end{array}$ & Reddish ........ & Fine ....................... & None ...... & ....... do...... & ......do & & \begin{tabular}{|} 
Muscov, hematite, kaolin, quartz, \\
chlorite.
\end{tabular} & ......do. & & & & Do. \\
\hline 54 & ...do .. & Mena, Polk County. & Greenish gray ... & Roughish.. & Waxy . & ......do ........ & $\mid \begin{array}{l}\text { Crystalline, extremely } \\
\text { fine, homogeneous. }\end{array}$ & 3 & Muscov., quartz, kaolin, chlorite .. & ....do .. & & & & $\begin{array}{l}\text { Specimen shows two extra foliations, which will prove } \\
\text { directions of wenkness. }\end{array}$ \\
\hline 54 & ...do ....... & Mammoth Red,Polk County & Light greenish.. & very fine.. & Almost none.. & Little....... & ......do ... & 1 & Muscov., quartz, kaolin, chlorite .. & ....... .. & & & & $\begin{array}{l}\text { Strcength, toughness, nnd behavior in freezing and thaw- } \\
\text { ing should be tested. }\end{array}$ \\
\hline 55 & ...do .... & $\begin{array}{l}\text { Sec. } 25, \text { T. } 3 \text { S., R. } 29 \text { W., } \\
\text { Polk Countr }\end{array}$ & Dark-bluish gray. & Fine............... & Slight ........ & Very little... & Crystalline, fine...... & 2 & Muscov., quartz, pyrite, carbon $\ldots$. & .....do .. & & & & \\
\hline 55 & ...do ... & $\begin{array}{l}\text { Pork County. } \\
\text { see. } 30 \text {, T. 3., R. } 28 \text { W., } \\
\text { Polk Conuty., }\end{array}$ & Light gray ..... & Roughish......... & None ....... & ....do . & ....do... & 2 & Muscov., quartz, chlorite, kaolin .. & .....do .. & $\therefore$ & & & Some limonite staining from pyrite. \\
\hline${ }_{55}$ & ....do ... & $\begin{array}{l}\text { Southwest Slate Mfg. Co., } \\
\text { Solk County } \\
\text { Poty }\end{array}$ & Very dark gray . & Roughish, spangled. & Almost none . & ....... . .... & $\begin{array}{c}\text { Crystalline, coarse, granu- } \\
\text { Jar }\end{array}$ & 3 & Muscov., quartz, carbon, pyrite.. & Some. & & & & Between a metamorphic grit and $a$ slate. \\
\hline 57 & California & $\begin{array}{l}\text { Eureka quarry, Eldorado } \\
\text { conuty }\end{array}$ & ......do ............. & Fine ...................... & Bright:........... & ...... . .... & Crystalline, fine .............. & 2 & Muscov., quartz, chlorite, carbon.: & ......do ... & 0.98 & & & See test, p. 47. \\
\hline 66 & Maine .... & Merrill quarry, Brownville. & .....do. & Very fine. & $\begin{array}{l}\text { Very bright ... } \\
\text { Slight }\end{array}$ & $\begin{array}{l}\text { Much.. } \\
\text { None }\end{array}$ & $\begin{array}{l}\text { Crystalline, very fine........ } \\
\text { Crsytallinee fine }\end{array}$ & 1 & Muscov., quartz, magnetite, pyrite.. & None.. & & 9,880 & 0.200 & $\begin{array}{l}\text { See p. } 66 \text { on nmount of magnetite. Sec tests on p. } 66 . \\
\text { Verv sonorous }\end{array}$ \\
\hline 63 & $\begin{array}{ll}\text { a.do. } \\
\text {...do. }\end{array}$ & Monson Pond, Monson ....... & $\begin{array}{ll}\text { a.do. } \\
\ldots . \text { do }\end{array}$ & $\begin{array}{l}\text { Roughi } \\
\cdots . . . \text { do }\end{array}$ & nest none......... & $\begin{array}{l}\text { None........ } \\
\text { Very little... }\end{array}$ & 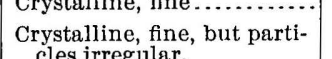 & 3 & $\begin{array}{l}\text { Muscovo,, chlorite, quartz, pyrnte.... } \\
\text { Muscov., quartz, chlorite, biotite ... }\end{array}$ & …do $\ldots$. & 0.52 & & & Very sonorous. See tests on p. 63. \\
\hline 63 & ... do ... & Maine Slate Co., of Monson. & ......do... & ......do...... & Bright...... & ......do.. & Crystalline, very fine......... & 2 & Muscoov., quartz, biotite, chlorite.. & 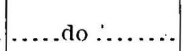 & & & & Very sonorous. \\
\hline $\begin{array}{l}64 \\
69\end{array}$ & \begin{tabular}{|l}
......do .......... \\
Maryland ....
\end{tabular} & $\begin{array}{l}\text { West Monso } \\
\text { Thurston .. }\end{array}$ & \begin{tabular}{|l}
$\mid . \ldots$ do ............... \\
Dark purplish ..
\end{tabular} & $\begin{array}{l}\text { Very fine .................. } \\
\text { Slightly granular.... }\end{array}$ & $\begin{array}{l}\text { Somewhat bright... } \\
\text { ….do .................. }\end{array}$ & $\begin{array}{l}\text { None } \ldots . . . . . \\
\text {.....do ....... }\end{array}$ & $\begin{array}{l}\text { Crystalline, fine ............... } \\
\text { Crystalline, fine, partícles }\end{array}$ & $\begin{array}{l}2 \\
3\end{array}$ & $\begin{array}{l}\text { Muscov., quartz, chlorite, pyrite ... } \\
\text { Muscov., chlorite, quartz, talc..... }\end{array}$ & $\begin{array}{l}\text { l....do .. } \\
\text { …do .. }\end{array}$ & ....... & 9,130 & \begin{tabular}{|c|c|}
0.205 \\
$\ldots \ldots \ldots .$.
\end{tabular} & $\begin{array}{l}\text { Very sonorous. Sce tests on p. } 123 \text {. } \\
\text { Sonoronsness very moderate; can besawn with hnndsaw. }\end{array}$ \\
\hline 72 & New York. & Granville and Hampton. & Reddish . & $\left\{\begin{array}{c}\text { Fine or re roughish, } \\
\text { speckled. }\end{array}\right.$ & & & …do ............................ & 3 & $\left\{\begin{array}{l}\text { Muscov., quartz, hematite, kaolin, } \\
\text { carb. }\end{array}\right.$ & \}unch. & $0.11^{0}$ & 9,220 & 0.232 & 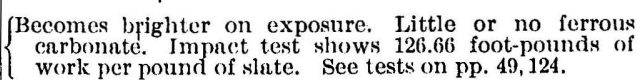 \\
\hline 74 & .....do ... & .....ио .................... & Bright greenish . & ..... do ..................... & $\ldots . .$. dó.. & ......do ..... & 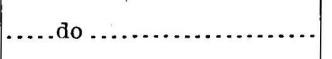 & 3 & \begin{tabular}{|l|} 
Muscov., quartz, chlorite, carbon, \\
magnetite.
\end{tabular} & $\begin{array}{l}\text { Less than red, } \\
\text { ussunlly }\end{array}$ & 1.43 & 8,050 & 0.190 & Said to be unfrading. See tests on p. 123 . \\
\hline 76 & Pennsylvania... & $\begin{array}{l}\text { Old Bangor, Northampton } \\
\text { County. }\end{array}$ & Very dark gray... & Fine ......... & Almost none ....... & Very little.... & Crystalline, fine ........... & 1 & Muscov., carb., quartz, kaolin......... & Quite a little.. & 4.38 & 9,810 & 0.312 & 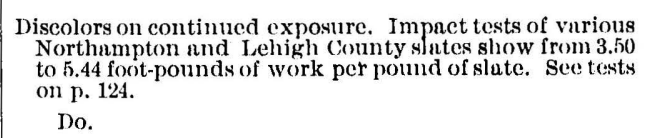 \\
\hline 79 & ....do. & $\begin{array}{l}\text { North Bangor, Northamp- } \\
\text { ton County } \\
\text { Albion, Pen Argyl............... }\end{array}$ & …...do. & Rough & & & ....do & & Muscov., carb., quartz, chlori & Quite: & 4.09 & 7,150 & $|0.270|$ & -5 \\
\hline 79 & ....do. & Albion, Gray bed............. & $\begin{array}{l}\text { Very dark green- } \\
\text { ish. }\end{array}$ & Roughish, granular . & ....do .... & Little.. & ....do. & 1 & Muscov., curb., quartz, chlorite.. & ......do & & & & \\
\hline 78 & ...do... & Heimbach, Big bed, North- & $\begin{array}{l}\text { Very dárk gray, } \\
\text { not bluish. }\end{array}$ & Somewhat fine ... & ......do ..... & $\begin{array}{l}\text { Extremely } \\
\text { little }\end{array}$ & ....do .. & 1 & Muscov., carb., quartz, pyrite ... & Very much. & & & & Do. \\
\hline 78 & ..do. & Heimbach, Black bed ....... & Bluish black ..... & Roughish. & None ......... & Very little .... & .....do.. & 1 & Muscov., earb., quartz, carbon & 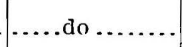 & & & & Discolors on continued exposure. \\
\hline 78 & ..do . & $\begin{array}{l}\text { East Bangor Consolidated, } \\
\text { Northampton County. }\end{array}$ & $\begin{array}{l}\text { Very dark bluish } \\
\text { gray. }\end{array}$ & Somewhat fine ........ & Almost none & some.. & .....do. & & $\begin{array}{l}\text { Muscov., carb., quartz, pyrite, chlor- } \\
\text { ite. }\end{array}$ & Much & & & & 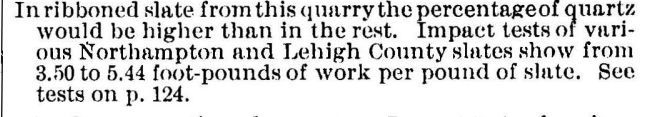 \\
\hline 84 & $\ldots$ do ............ & Slatington, Lehigh County. & .....do ........ & ......do ... & ....do ... & Little.. & .....do ..................... & 1 & Muscov., carb., quartz, kaolin.... & .....do ....... & 4.23 & & & 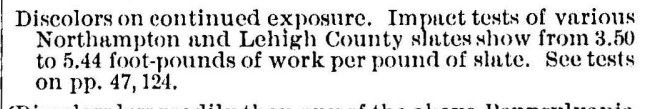 \\
\hline 81 & ... dо ... & Chapman "hard vein".... & Very dark gray... & Slightly roughish .. & Slight. & Some.. & …do. & 2 & Muscov., quartz, carb., pyrite . & Quite a little. & $\left\{\begin{array}{l}2.83- \\
3.40\end{array}\right.$ & 9,460 & 0.212 & 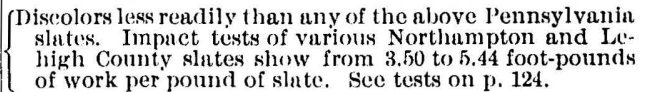 \\
\hline 86 & $\begin{array}{l}\text { Pennsylvania- } \\
\text { Maryland. }\end{array}$ & \}Peach Bottom & $\left\{\begin{array}{l}\text { Very dark bluish } \\
\text { gray. }\end{array}\right.$ & Minutely granular . & Very bright & ......do . & Crystalline, coarse ... & 2 & $\left\{\begin{array}{l}\text { Muscov., quartz,graphite, andalusite, } \\
\text { magnetite. }\end{array}\right.$ & None ... & $\begin{array}{l}0.155- \\
0.48\end{array}$ & 11,260 & 0.93 & 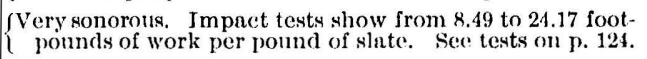 \\
\hline 91 & vermont & $\begin{array}{l}\text { Northfield, Vermont Black } \\
\text { Slate Co }\end{array}$ & Very dark gray... & Very fine ... & ......do... & Very little. & Crystalline, very fine.. & 1 & Muscov., quartz, pyrite, magnetite.. & Very little.. & & & & Very sonorons. \\
\hline 104 & $\therefore$ do. & "Sea green" $\ldots$ & Gray greenish .... & Fine.... & Waxy . & ......do.. & …..do .............. & 1 & Muscov., quartz, carb., chlorite . & Much........ & $\left\{\begin{array}{l}0.62- \\
2.20\end{array}\right\}$ & 7,250 & 0.207 & 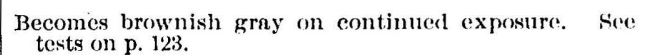 \\
\hline 107 & ...do.. & Purplish of "sea green". & Purplish brown... & ......do.. & None. & ...... . & ......do. & 1 & Muscov., quartz, carb., hematite.. & some ...... & $\left\{\begin{array}{l}0.50- \\
0.71\end{array}\right.$ & & & Discoloration less pronouneed thun that of "sen green." \\
\hline 106 & ....do.. & "Unfading green "....... & Greenish gray .... & Roughish.. & ......do .. & some. & Crystalline, irregular..... & 2 & Muscov., quartz, chlorite, carb...... & very little... & $\left\{\begin{array}{l}0.42- \\
0.56\end{array}\right.$ & 6,410 & 0.225 & $\left\{\begin{array}{l}1 \text { reseserves nearly all itt color on continued exposure. See } \\
\text { tests on p. } 124 .\end{array}\right.$ \\
\hline 107 & & Purplish & & & & & & & & & & & & \\
\hline $\begin{array}{l}110 \\
113\end{array}$ & $\begin{array}{l}\text {....do ... } \\
\text { Virginia : }\end{array}$ & Arvonia Williams.......... & & $\begin{array}{l}\text { Somewhat fine } \ldots . . . . . \\
\text { Minutely granular } \ldots . .\end{array}$ & $\begin{array}{l}\text { Slight .......... } \\
\text { Very bright ... }\end{array}$ & & $\begin{array}{l}\text { Crystalline, fine.............. } \\
\text { Crrstalline, irregular }\end{array}$ & \begin{tabular}{r|r}
2 \\
.2
\end{tabular} & & & 1.27 & 9040 & 0.227 & 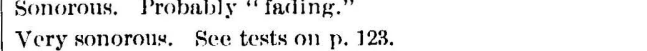 \\
\hline 114 & .................. & Arvonia, Fontaine...... & 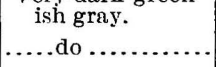 & Granular .............. & .............. & ......do ...... & Crystall ine, irregular, & 2 & $\left|\begin{array}{ccc}\text { carbon." } & \text { uurtz, } \\
\text { Muscov., } & \text { biotite, carb., }\end{array}\right|$ & .....do ....... & & 9,850 & 0.225 & Do. \\
\hline${ }_{116}^{115}$ & & Bremo ( & & Fine sp & & & & & & & & & & \\
\hline $\begin{array}{l}116 \\
121\end{array}$ & $\begin{array}{l}\text {.....do ............ } \\
\text { West Virginia . }\end{array}$ & $\begin{array}{l}\text { Snowden } \ldots \ldots \ldots \ldots \ldots \ldots \ldots \ldots \\
\text { Martinsburg ..................... }\end{array}$ & $\begin{array}{l}\text { Viery dark gray ... } \\
\text { Black, brownish }\end{array}$ & $\begin{array}{l}\text { Minutely granular ... } \\
\text { Roughish............. }\end{array}$ & $\begin{array}{l}\text { Almost none } \ldots . . . . . \\
\text { None ............... }\end{array}$ & $\begin{array}{l}\text {......do ..... } \\
\text { Little..... }\end{array}$ & $\begin{array}{l}\text { Crystalline, fine, irregular.. } \\
\text { Not crystalline or imper-. }\end{array}$ & $\begin{array}{l}2 \\
3\end{array}$ & $\left|\begin{array}{l}\text { Muscov., quartz, chlorite, kaolin...... } \\
\text { Carb., muscov., quartz, krolin, py- } \\
\text { rił, }\end{array}\right|$ & $\mid \begin{array}{l}\text { Little............ } \\
\text { From some to } \\
\text { much }\end{array}$ & 1.11. & & & $\begin{array}{l}\text { Very sonorouns. } \\
\text { Analysist ov W. W. Tilden. In some specimens muscovite }\end{array}$ \\
\hline & & & & & & & & & & & & & & \\
\hline
\end{tabular}



Maximum fiber stress per square inch .............................. 7,671

Shearing test per square inch.................................

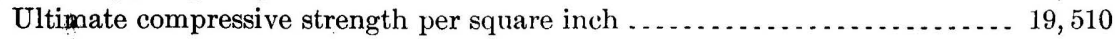

Coefficient of expansion, 0.000005 .

The relative commercial value of several slates is an index of their physical characteristics. Mathews, in 1898, gave these prices for slates 14 by 7 inches, threesixteenths thick, per square: Peach Bottom, $\$ 4.85$; Northampton County, Pa., $\$ 3.50$; Lehigh County, Pa., $\$ 3.40-\$ 3.95$; Maine (No. 1), $\$ 6.40$; Arvonia, Va., $\$ 3.60$; unfading green, Vermont, $\$ 4.50$; red, New York, $\$ 11 . a$

The following prices per square for slates, No. 1 quality, 16 by 8 inches, f. o. b., were obtained by Doctor Day from producers for January, 1905: Peach Bottom, $\$ 6.35$; Monson, Me., $\$ 7.20$; red, New York, $\$ 11$; Bangor, Pa.; $\$ 5.75$; Albion, Pa., \$5; Pen Argyl, Pa., \$4.75; Chapman, Pa., hard vein, \$5.25; Slatington, Pa., $\$ 4.50$ to $\$ 5$; unfading green, Vermont, $\$ 4.50$ to $\$ 5.25$; sea green, Vermont, $\$ 3.50$; Virginia, $\$ 5$ to $\$ 5.50$.

In accordance with the scheme of classification of slates given on page 6 , most of the slates whose characteristics are given on the preceding table are here arranged systeńatically:

(A) Clay-slates ( $\mathrm{F}_{\mathrm{Ading}}$ ) Martinsburg, W. Va.

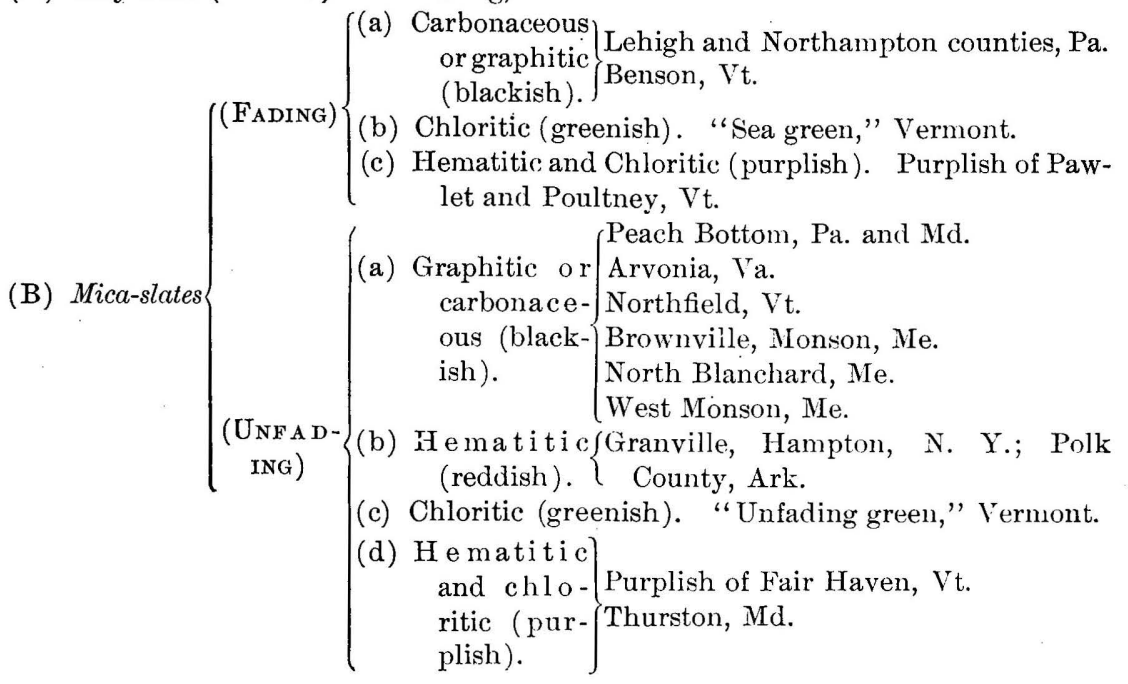

STATISTICS OF PRODUCTION, IMPORTS, AND EXPORTS.

By A. T. Coons.

PRODUCTION.

Although slate has been known and quarried in this country, more or less, since 1750, when we find records of its use in Massachusetts, Maryland, and Pennsylvania, and since about 1850 in New York, Vermont, Georgia, California, Virginia, and other States, no statistics of production for the entire United States are obtainable for any year preceding 1879.

For the years $1879,1881,1882$, and 1883 the production is largely estimated. The statistics for 1880 are taken from the Tenth Census and are very accurate. The figures from 1884 to 1888 are fairly reliable, and from 1889, when the figures are those 


\section{SLATE DEPOSITS AND INDUSTRY OF UNITED STATES،}

of the Eleventh Census, to the present time, the data as to production have been obtained directly from the slate quarries, and are as accurate as can be procured. There is no record of production in New York from 1884 to 1890, but the operations in this State being closely allied to those of Vermont the output is doubtless included in that of Vermont.

The following tables give the output of slate in the United States from 1879 to 1904, by States, showing, as nearly as possible, the number of squares of roofing slate produced, their value, and the value of slate used for other purposes, as far as figures are obtainable:

Production of slate in the United States, by years, from 1879 to 1904.

\begin{tabular}{|c|c|c|c|c|c|c|c|c|c|}
\hline \multirow[b]{2}{*}{ State or Territory. } & \multicolumn{2}{|c|}{1879.} & \multicolumn{2}{|r|}{1880.} & \multicolumn{2}{|c|}{1881.} & \multicolumn{3}{|c|}{1882.} \\
\hline & $\begin{array}{l}\text { Roofing } \\
\text { slate, } \\
\text { squares. }\end{array}$ & Value. & $\begin{array}{l}\text { Roofin } \\
\text { slate, } \\
\text { square }\end{array}$ & Value. & $\begin{array}{l}\text { Roofing } \\
\text { slate, } \\
\text { squares. }\end{array}$ & Value. & $\begin{array}{l}\text { Roof } \\
\text { slat } \\
\text { squar }\end{array}$ & & Value. \\
\hline \multicolumn{10}{|l|}{ Arkansas. } \\
\hline \multicolumn{10}{|l|}{ California .............. } \\
\hline Georgia ............. & ........... & ........... & 1,000 & $\$ 4,500$ & 500 & $\$ 2,250$ & & 200 & $\$ 900$ \\
\hline Maine..... & 14,000 & $\$ 42,000$ & 26,200 & 84,800 & 25,200 & 77,500 & 26,0 & 000 & 78,000 \\
\hline Maryland ..... & 8,000 & 36,000 & 12,280 & $\therefore 6,700$ & 12,000 & 54,000 & 15,0 & 000 & 67,500 \\
\hline Massachusetts & ….... & & 1,550 & 7,000 & $1, .000$ & 4,500 & & 500 & 2,000 \\
\hline \multicolumn{10}{|l|}{ Michigan ............... } \\
\hline \multicolumn{10}{|l|}{ Minnesota ............. } \\
\hline \multicolumn{10}{|l|}{ New Jersey ............. } \\
\hline \multirow{2}{*}{\multicolumn{10}{|c|}{$\begin{array}{l}\text { New York................. } \\
\text { Pennsylvania......... }\end{array}$}} \\
\hline & 245,500 & 826,093 & 271,31 & 862,877 & 272,000 & 877,978 & 292,0 & & $1,002,000$ \\
\hline \multicolumn{10}{|l|}{ Tennessee...........} \\
\hline \multicolumn{10}{|l|}{ 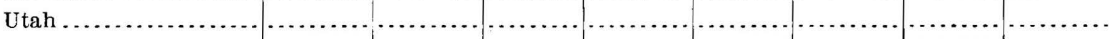 } \\
\hline \multirow{3}{*}{\multicolumn{10}{|c|}{$\begin{array}{l}\text { Vermont } \ldots \ldots \ldots \ldots \\
\text { Virginia } \ldots \ldots \ldots \ldots \\
\text { Other States .............. }\end{array}$}} \\
\hline & & & & & & & & & \\
\hline & & & & & & & & & \\
\hline \multirow[t]{2}{*}{ Total.............. } & 367,8571, & $1,231,221$ & 457,267 & $71,529,985$ & 454,0701, & $1,543,838$ & \multicolumn{2}{|c|}{501,000} & $1,753,500$ \\
\hline & & 1883. & & & & 1884. & & & \\
\hline State or Territory. & $\begin{array}{l}\text { Roofing } \\
\text { slate, } \\
\text { squares. }\end{array}$ & \multicolumn{2}{|c|}{ Value. } & $\begin{array}{l}\text { Roofing } \\
\text { slate, } \\
\text { squares. }\end{array}$ & Value. & \multicolumn{2}{|c|}{$\begin{array}{c}\text { Other pur- } \\
\text { poses than } \\
\text { roofing } \\
\text { slate. }\end{array}$} & Tot: & al value. \\
\hline \multicolumn{10}{|l|}{ Arkansas. } \\
\hline \multicolumn{10}{|l|}{ California.. } \\
\hline Georgia .... & & & & & & & & & \\
\hline Maine.......... & 30,000 & $\$ 12$ & 20,000 & 41,000 & $\$ 215,000$ & & & & $\$ 215,000$ \\
\hline Maryland ...... & 15,000 & & 7,500 & $a 10,000$ & 45,000 & & & & 45,000 \\
\hline Massachusetts & ….... & & $\cdots$ & & & & & & \\
\hline Michigan ....... & 5,000 & & 18,250 & 7,000 & 35,300 & & & & 35,300 \\
\hline Minne & …..... & & . & & & & & & \\
\hline New Jersey ... & 1,000 & & 4,000 & & & & & & \\
\hline New York.............. & 10,200 & & 51,000 & ........ & & & & & $\cdots \ldots \ldots \ldots$ \\
\hline Pennsylvania.......... & 325,000 & 1,14 & 17,500 & 329,004 & $1,162,560$ & & & & $1,162,560$ \\
\hline Tennessee.......... & ......... & . & .... & ......... & $\ldots \ldots \ldots \ldots$ & & & & .......... \\
\hline Utah ....... & & & ........ & & & & & & ...... \\
\hline Vermont...................... & 110,000 & & 10,000 & 85,000 & 340,500 & & & & 340,500 \\
\hline 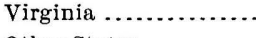 & 10,000 & & 0,000 & 9,000 & 45,505 & & $\cdots$ & & 45,505 \\
\hline Other States & & & & & & & & & (n....... \\
\hline Total.. & 506,200 & 1,89 & 8,250 & 481,004 & $1,843,865$ & & 88,000 & & $1,851,865$ \\
\hline
\end{tabular}

$a$ Includes Pennsylvania Peach Bottom. 
Production of slate in the United Stutes, by years, from 1879 to 1907-Continued.

\begin{tabular}{|c|c|c|c|c|c|c|c|c|c|}
\hline \multirow[b]{2}{*}{ State or Territory. } & \multicolumn{4}{|c|}{1885.} & \multicolumn{2}{|l|}{1886.} & \multicolumn{3}{|c|}{1887.} \\
\hline & $\begin{array}{l}\text { Roofing } \\
\text { slate, } \\
\text { squares. }\end{array}$ & Value. & $\begin{array}{l}\text { Other } \\
\text { purpos } \\
\text { than } \\
\text { roofin } \\
\text { slate }\end{array}$ & $\begin{array}{l}\text { Total } \\
\text { value. }\end{array}$ & $\begin{array}{c}\text { Roofing } \\
\text { slate, } \\
\text { squares. }\end{array}$ & Value. & $\begin{array}{l}\text { Rooti } \\
\text { slatt } \\
\text { squar }\end{array}$ & & Value. \\
\hline \multicolumn{10}{|l|}{ Arkansas } \\
\hline \multicolumn{10}{|l|}{ California............. } \\
\hline \multicolumn{10}{|l|}{ 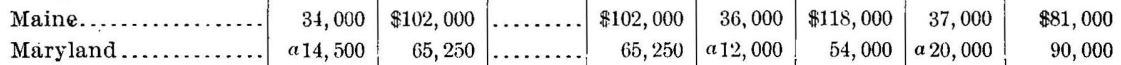 } \\
\hline \\
\hline & & & & & & & & & \\
\hline \multicolumn{10}{|l|}{$\begin{array}{l}\text { Michigan } . \ldots \\
\text { Minnesota }\end{array}$} \\
\hline \multicolumn{10}{|l|}{$\begin{array}{l}\text { Minnesota . . . . . . . . . . } \\
\text { New Jersey . ............. }\end{array}$} \\
\hline \multicolumn{10}{|l|}{ New York............. } \\
\hline \multirow{2}{*}{\multicolumn{10}{|c|}{$\begin{array}{l}\text { Pennsylvania . . . . . . . . } \\
\text { Tennessee ............. }\end{array}$}} \\
\hline & & & & & & & & & \\
\hline \multicolumn{10}{|l|}{ Utah $\ldots \ldots \ldots \ldots \ldots \ldots$} \\
\hline \multirow{3}{*}{\multicolumn{10}{|c|}{$\begin{array}{l}\text { Vermont } \ldots \ldots \ldots \ldots \ldots \\
\text { Virginia } . . . \ldots \ldots \ldots \ldots \\
\text { Other States ............ }\end{array}$}} \\
\hline & & & & & & & & & \\
\hline & & & & & & & & & \\
\hline \multirow[t]{2}{*}{ Total... } & $\begin{array}{ll}536,960 & 1,\end{array}$ & $1,638,467$ & $\$ 10,000$ & $101,648,467$ & $\begin{array}{ll}536,790 & 1,6\end{array}$ & $1,610,370$ & \multicolumn{2}{|c|}{573,439} & $1,720,317$ \\
\hline & \multicolumn{3}{|c|}{1888.} & \multicolumn{6}{|c|}{1889.} \\
\hline State or Territory. & $\begin{array}{l}\text { Roofing } \\
\text { slate, } \\
\text { squares. }\end{array}$ & Valt & & $\begin{array}{l}\text { Roofing } \\
\text { slate, } \\
\text { squares. }\end{array}$ & Value. & $\begin{array}{l}\text { Oth } \\
\text { purp } \\
\text { the } \\
\text { roof } \\
\text { slat }\end{array}$ & $\begin{array}{l}\text { aer } \\
\text { oses } \\
\text { an } \\
\text { fing } \\
\text { te. }\end{array}$ & Tot: & al value. \\
\hline \multicolumn{10}{|l|}{ Arkansas } \\
\hline California..... & & & ....... & 3,104 & $\$ 18,089$ & & …... & & $\$ 18,089$ \\
\hline Georgia ....... & ......... & $\cdots$ & ....... & 3,050 & 14,850 & & $\$ 480$ & & 15,330 \\
\hline Maine............ & 37,000 & $\$ 11$ & 1,000 & 41,000 & 201,500 & & 8,000 & & 219,500 \\
\hline Maryland ......... & $a 19,000$ & & 5,500 & 23,099 & 105,745 & & 4,263 & & 110,008 \\
\hline \multicolumn{10}{|l|}{ Massachu'setts ...... } \\
\hline \multirow{2}{*}{\multicolumn{10}{|c|}{$\begin{array}{l}\text { Michigan } \ldots \ldots \ldots \ldots \ldots \\
\text { Minnesota } . . . \ldots \ldots \ldots\end{array}$}} \\
\hline & & & & & & & & & \\
\hline New Jersey ............. & 6,000 & & 2,000 & 2,700 & 9,675 & & 1,250 & & ) 10,925 \\
\hline New York................. & (n......... & $\cdots \cdots$ & $\cdots \cdots$ & 16,767 & 81,726 & & 4,877 & & $126,6 \cup 3$ \\
\hline Pennsylvania......... & 416,000 & 1,270 & 0,400 & 476,038 & $1,641,003$ & & 0,723 & & $2,011,726$ \\
\hline Tennessee.... & -....... & & & & & & & & \\
\hline Utah ................. & (n............. & $\cdots$ & $\cdots \cdots$ & $\ldots \ldots$. & $\ldots \ldots \ldots$ & $\cdots$ & $\cdots \cdots$ & & $(b)$ \\
\hline Vermont........... & 160,000 & & 30,000 & $23 t, 350$ & 596,997 & & 5,016 & & 842,013 \\
\hline Virginia ............ & 17,400 & & 0,540 & 30,457 & 113,079 & & …... & & 113,079 \\
\hline Other Stutes ....... & (............ & & ....... & 3,060 & 15,240 & & $\cdots \cdots$ & & 15,240 \\
\hline Total... & 662,400 & 2,05 & 3,440 & 835,625 & $2,797,904$ & & 4,609 & & $3,4 \times 2,513$ \\
\hline
\end{tabular}

a Includes Pennsylvania Peach Bottom. $b$ Included in other States.

Bull. $275-06-10$ 


\section{SLATE DEPOSITS AND INDUSTRY OF UNITED STATES.}

Production of slate in the United States, by years, from 1879 to 1904-Continued.

\begin{tabular}{|c|c|c|c|c|c|c|c|c|}
\hline \multirow{2}{*}{ Ștate or Territory. } & \multicolumn{4}{|c|}{1891.} & \multicolumn{4}{|c|}{$189^{\circ}}$. \\
\hline & $\begin{array}{l}\text { Roofing } \\
\text { slate, } \\
\text { squares. }\end{array}$ & Value. & $\begin{array}{c}\text { Other } \\
\text { purposes } \\
\text { than } \\
\text { roofing } \\
\text { slate. }\end{array}$ & $\begin{array}{l}\text { Total } \\
\text { value. }\end{array}$ & $\begin{array}{l}\text { Roofing } \\
\text { slate, } \\
\text { squares. }\end{array}$ & Value. & $\begin{array}{c}\text { Other } \\
\text { purposes } \\
\text { than } \\
\text { roofing } \\
\text { slate. }\end{array}$ & $\begin{array}{l}\text { Total } \\
\text { value. }\end{array}$ \\
\hline Arkansas :.... & 120 & $\$ 480$ & & $\$ 480$ & & & & ............ \\
\hline California... & 4,000 & 24,000 & & 24,000 & 3,500 & $\$ 21,000$ & $\ldots \ldots \ldots$ & $\$ 21,000$ \\
\hline Georgia ....... & 3,000 & 13,500 & & 13,500 & 2,500 & 10,625 & .......... & 10,625 \\
\hline Maine.......... & 50,000 & 250,000 & .......... & 250,000 & 50,000 & 250,000 & n......... & 250,000 \\
\hline Maryland ...... & 25,166 & 123,425 & $\$ 2,000$ & 125,425 & 24,000 & 114,000 & $\$ 2,500$ & 116,500 \\
\hline \multirow{2}{*}{\multicolumn{9}{|c|}{$\begin{array}{l}\text { Massachusetts.......... } \\
\text { Michigan ................ }\end{array}$}} \\
\hline & & & & . & . & an........ & $\mid \cdots \ldots \ldots$ & $\ldots \ldots \ldots$ \\
\hline \multicolumn{9}{|l|}{ Minnesota ............... } \\
\hline New Jersey ............. & 2,500 & 10,000 & .......... & 10,000 & 3,000 & 12,000 & n......... & 12,000 \\
\hline New York..... & 17,000 & 136,000 & 40,000 & 176,000 & 20,000 & 160,000 & 50,000 & 210,000 \\
\hline Pennsylvania........... & 507,824 & $1,741,836$ & 401,069 & $2,142,905$ & 550,000 & $1,925,000$ & 408,000 & $2,333,000$ \\
\hline \multicolumn{9}{|l|}{ Tennessee...........} \\
\hline \multicolumn{9}{|l|}{ Utah $\ldots \ldots \ldots \ldots$} \\
\hline Vermont .................... & 247,643 & 698,350 & 257,267 & 955,617 & 260,000 & 754,000 & 260,000 & $1,014,000$ \\
\hline 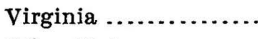 & 36,059 & 127,819 & -.......... & 127,819 & 40,000 & 150,000 & ............ & 150,000 \\
\hline \multicolumn{9}{|l|}{ Other States ................. } \\
\hline Total.... & 893,312 & $3,125,410$. & 700,336 & $3,825,746$ & 953,000 & $3,396,625$ & 720,500 & $4,117,125$ \\
\hline \multirow[b]{2}{*}{ State or Territory. } & \multicolumn{4}{|c|}{1893.} & \multicolumn{4}{|c|}{1894.} \\
\hline & $\begin{array}{l}\text { Roofing } \\
\text { slate, } \\
\text { squares. }\end{array}$ & Value. & $\begin{array}{l}\text { Other } \\
\text { purposes } \\
\text { than } \\
\text { roofing } \\
\text { slate. }\end{array}$ & $\begin{array}{l}\text { Total } \\
\text { value. }\end{array}$ & $\begin{array}{l}\text { Roofing } \\
\text { slate, } \\
\text { squares. }\end{array}$ & Value. & $\mid \begin{array}{c}\text { Other } \\
\text { purposes } \\
\text { than } \\
\text { roofing } \\
\text { slate. }\end{array}$ & $\begin{array}{l}\text { Total } \\
\text { value. }\end{array}$ \\
\hline \multicolumn{9}{|l|}{ Arkansas ................... } \\
\hline California................... & $\ldots \ldots \ldots$ & & & $\cdots \ldots \ldots \ldots$ & 900 & $\$ 5,850$ & .......... & $\$ 5,850$ \\
\hline Georgia ............. & 2,500 & $\$ 11,250$ & ........... & $\$ 11,250$ & 5,000 & 22,500 & …...... & 22,500 \\
\hline Maine............. & 18,184 & 124,200 & $\$ 15,000$ & 139,200 & 24,690 & 123,937 & $\$ 22,901$ & 146,838 \\
\hline Maryland................. & 7,422 & 37,884 & .......... & 37,884 & 39,460 & 150,568 & 2,500 & 153,068 \\
\hline \multirow{2}{*}{\multicolumn{9}{|c|}{$\begin{array}{l}\text { Massachusetts } \ldots \ldots \ldots \\
\text { Michigan } . . . \ldots \ldots \ldots \ldots\end{array}$}} \\
\hline & n..... & …….. & 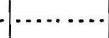 & .......... & , n.......... & 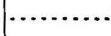 & 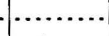 & ............ \\
\hline \multicolumn{9}{|l|}{ Minnesota ............... } \\
\hline New Jersey ...... & 900 & 3,653 & $\ldots . . . .$. & 3,653 & 375 & 1,050 & ........... & 1,050 \\
\hline New York......... & 69,640 & 204,776 & 206 & 204,982 & 7,955 & 42,092 & 2,450 & 44,542 \\
\hline Pennsylvania....... & 364,051 & $1,314,451$ & 157,824 & $1,472,275$ & 411,550 & $1,380,430$ & 239,728 & $1,620,158$ \\
\hline \multicolumn{9}{|l|}{ Tennessee ......... } \\
\hline Utah ................... & 75 & 450 & 400 & 850 & ........... & ............. & .......... & n.......... \\
\hline Vermont............. & 132,061 & 407,538 & 128,194 & 535,732 & 214,337 & 455,860 & 202,307 & 658,167 \\
\hline Virginia .................... & 27,106 & 104,847 & 12,500 & 117,347 & $33,9 \overline{5} 5$ & 118,851 & 19,300 & 138,151 \\
\hline \multicolumn{9}{|l|}{ Other States ................... } \\
\hline Total... & 621,939 & $2,209,049$ & 314,124 & $2,523,173$ & $\dot{7} 38,222$ & $2,301,138$ & 489,186 & $2,790,324$ \\
\hline
\end{tabular}


Production of slate in the United States, by years, from 1879 to 1904-Continued.

\begin{tabular}{|c|c|c|c|c|c|c|c|c|}
\hline \multirow[b]{2}{*}{ State or Territory. } & \multicolumn{4}{|c|}{1895.} & \multicolumn{4}{|c|}{1896.} \\
\hline & $\begin{array}{c}\text { Roofing } \\
\text { slate, } \\
\text { squares. }\end{array}$ & Value. & $\begin{array}{c}\text { Other } \\
\text { purposes } \\
\text { than } \\
\text { roofing } \\
\text { slate. }\end{array}$ & $\begin{array}{l}\text { Total } \\
\text { value. }\end{array}$ & $\begin{array}{l}\text { Roofing } \\
\text { slate, } \\
\text { squares. }\end{array}$ & Value. & $\begin{array}{l}\text { Other } \\
\text { purposes } \\
\text { than } \\
\text { roofing } \\
\text { slate. }\end{array}$ & $\begin{array}{l}\text { Total } \\
\text { valuc. }\end{array}$ \\
\hline \multicolumn{9}{|l|}{ Arkansas ................. } \\
\hline California..... & 1,500 & $\$ 10,500$ & ........ & $\$ 10,500$ & ...... & $\cdots$ & & $\ldots \ldots \ldots$ \\
\hline Georgia .......... & 2,500 & 10,675 & .......... & 10,675 & 4,597 & $\$ 20,388$ & .......... & $\$ 20,388$ \\
\hline Maine............. & 23,774 & $.118,791$ & $\$ 21,363$ & 140,154 & 23,078 & 99,831 & $\$ 24,255$ & 124,086 \\
\hline Maryland ....... & 13,188 & 59,157 & 1,200 & 60,357 & 15,557 & 70,194 & 1,948 & 72,142 \\
\hline Massachusetts ......... & $\cdots \cdots \cdots$ & ....... & $\cdots$ & $\cdots$ & & & 1,200 & 1,200 \\
\hline \multicolumn{9}{|l|}{ Michigan ............... } \\
\hline \multicolumn{9}{|l|}{ Minnesota ........ } \\
\hline New Jersey ... & - 200 & 700 & $\cdots \cdots \cdots$ & 700 & 200 & 700 & ......... & 700 \\
\hline New York....... & 13,624 & 90,150 & 1,725 & 91,875 & 16,002 & 78,612 & 3,880 & 82,492 \\
\hline Pennsylvania . & 426,687 & $1,437,697$ & 210,054 & $1,647,751$ & 431,324 & $1,391,539$ & 334,779 & $1,726,318$ \\
\hline Tennessee...... & . & & & & $\mathbf{1 6 0}$ & 640 & 780 & 1,420 \\
\hline \multicolumn{9}{|l|}{ Utah ....... } \\
\hline Vermont.. & 221,359 & 531,482 & 93,849 & 625,331 & 155,523 & 509,681 & 99,915 & 609,596 \\
\hline Virginia ............. & 27,095 & 92,357 & 19,000 & 111,357 & 26,863 & 92,163 & 15,700 & 107,863 \\
\hline \multicolumn{9}{|l|}{ Other States ............... } \\
\hline \multirow[t]{2}{*}{ Total.. } & 729,927 & $2,351,509$ & 347,191 & $2,698,700$ & 673,304 & $2,263,748$ & 482,457 & $2,746,205$ \\
\hline & \multicolumn{4}{|c|}{1897.} & \multicolumn{4}{|c|}{1898.} \\
\hline State or Territory. & $\begin{array}{l}\text { Roofing } \\
\text { slate, } \\
\text { squares. }\end{array}$ & Value. & $\begin{array}{c}\text { Other } \\
\text { purposes } \\
\text { than } \\
\text { roofing } \\
\text { slate. }\end{array}$ & $\begin{array}{l}\text { Total } \\
\text { value. }\end{array}$ & $\begin{array}{l}\text { Roofing } \\
\text { slate, } \\
\text { squares. }\end{array}$ & Value. & $\begin{array}{c}\text { Other } \\
\text { purposes } \\
\text { than } \\
\text { roofirig } \\
\text { slate. }\end{array}$ & $\begin{array}{l}\text { Total } \\
\text { value. }\end{array}$ \\
\hline \multicolumn{9}{|l|}{ Arkansas } \\
\hline California. . & 1,000 & $\$ 7,000$ & & $\$ 7,000$ & 400 & $\$ 2,700$ & & $\$ 2,700$ \\
\hline Georgia .......... & .......... & n........ & .......... & .......... & 3,450 & 13,125 & …....... & 13,125 \\
\hline Maine............... & 38,367 & 161,262 & $\$ 39,855$ & 201,117 & 29,834 & 131,752 & $\$ 67,485$ & 199,237 \\
\hline Maryland ............... & 11,592 & 53,049 & 890 & 53,939 & 18,332 & 80,786 & 1,454 & 82,240 \\
\hline \multicolumn{9}{|l|}{ Massachusetts ........... } \\
\hline \multicolumn{9}{|l|}{ Michigan .................. } \\
\hline Minnesota ..... & 400 & 1,000 & 500 & 1,500 & 100 & 400 & & 400 \\
\hline New Jersey .... & 250 & 775 & $\cdots \cdots \cdots$ & 775 & 200 & 800 & $\ldots \ldots \ldots$ & 800 \\
\hline New York.......... & 9,197 & 52,799 & 1,000 & 53,799 & 7,160 & 46,744 & 1,950 & 48,694 \\
\hline Pennsylvania.......... & 657,692 & $2,034,958$ & 330,341 & $2,365,299$ & 571,256 & $2,097,735$ & 394,021 & $2,491,756$ \\
\hline \multicolumn{9}{|l|}{ Tennessee $. . . . \ldots \ldots \ldots . . .}$. \\
\hline \multicolumn{9}{|l|}{ 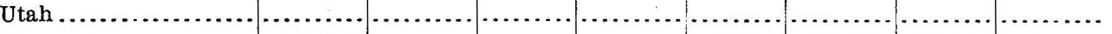 } \\
\hline Vermont.................... & 244,575 & 656,114 & 39,701 & 695,815 & 241,762 & 612,902 & 119,782 & 732,684 \\
\hline Virginia ................. & 38,375 & $130 ; 495$ & 14,875 & 145,370 & 43,745 & 142,446 & 8,500 & 150,946 \\
\hline \multicolumn{9}{|l|}{ Other States .............. } \\
\hline Total. & $1,001,448$ & $3,097,452$ & 427,162 & $3,524,614$ & 916,239 & $3,129,390$ & 594,150 & $3,723,540$ \\
\hline
\end{tabular}


Production of slate in the United States, by years, from 1879 to 1904-Continued.

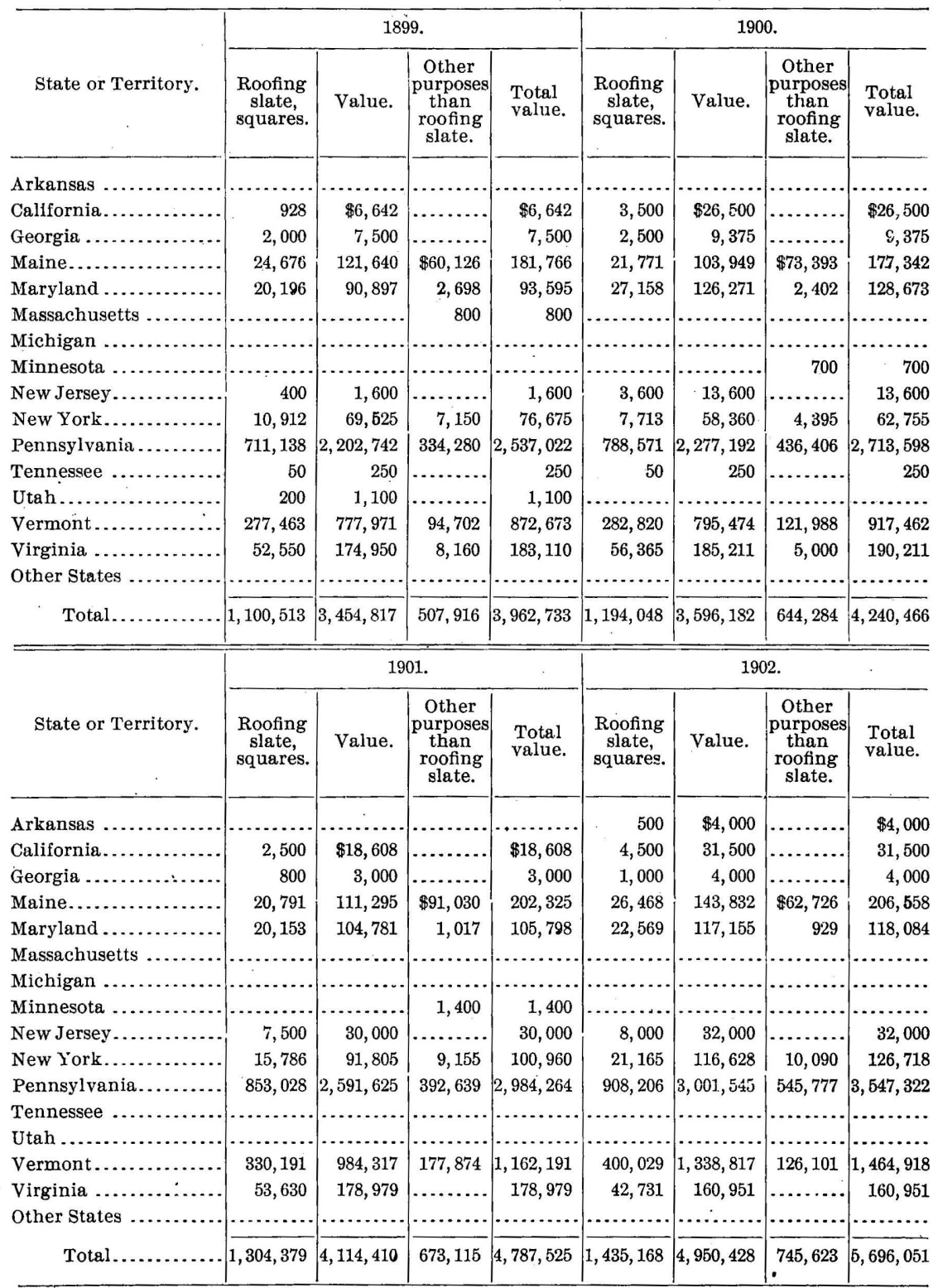


Production of slate in the United States, by years, from 1879 to 1904-Continued.

\begin{tabular}{|c|c|c|c|c|c|c|c|c|}
\hline \multirow[b]{2}{*}{ State or Territory. } & \multicolumn{4}{|c|}{1903.} & \multicolumn{4}{|c|}{1904.} \\
\hline & $\begin{array}{l}\text { Roofing } \\
\text { slate, } \\
\text { squares. }\end{array}$ & .Value. & $\mid \begin{array}{c}\text { Other } \\
\text { purposes } \\
\text { than } \\
\text { roofing } \\
\text { slate. }\end{array}$ & $\begin{array}{c}\text { Total } \\
\text { value. }\end{array}$ & $\begin{array}{l}\text { Roofing } \\
\text { slate, } \\
\text { squares. }\end{array}$ & Value. & $\begin{array}{c}\text { Other } \\
\text { purposes } \\
\text { than } \\
\text { roofing } \\
\text { slate. }\end{array}$ & $\begin{array}{l}\text { Total } \\
\text { value. }\end{array}$ \\
\hline Arkansas ...... & 118 & $\$ 709$ & $\$ 4,000$ & $\$ 4,709$ & 1,750 & $\$ 10,300$ & $\$ 4,000$ & $\$ 14,300$ \\
\hline California...... & 10,000 & 70,000 & & 70,000 & 5,600 & 39,200 & ............ & 39,200 \\
\hline Georgia............ & …...... & …...... & & . & 1,000 & 4,500 & n....... & 4,500 \\
\hline Maine............. & 27,377 & 157,911 & 73,319 & 231,230 & 20,789 & 120,838 & 60,330 & 181,168 \\
\hline $\begin{array}{l}\text { Maryland...... } \\
\text { Massachusetts . }\end{array}$ & 24,475 & 135,424 & 2,207 & 137,631 & 22,628 & 131,245 & 2,727 & 133,972 \\
\hline Michigan ..... & & & & & & & & \\
\hline Minnesota & & $\cdots$ & & & & & & $\cdots$ \\
\hline New Jersey ..... & 7,647 & 33,403 & …........ & 33,403 & 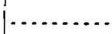 & . & ?....... & . n........ \\
\hline New York....... & 15,690 & 89,548 & 22,450 & 111,998 & 10,022 & 64,102 & 7,441 & 71,543 \\
\hline Pennsylvania.. & 871,875 & $3,378,804$ & 581,102 & $3,959,906$ & 778,825 & $2,922,259$ & 710,987 & $3,633,246$ \\
\hline Tennessee ....... & ;.... & & & & 115 & 607 & & 607 \\
\hline Utah ....... & .......... & .......... & ......... & ............ & 50 & 300 & & 300 \\
\hline Vermont........... & 391,366 & $1,363,923$ & 228,729 & $1,592,652$ & 361,126 & $1,245,730$ & 162,421 & $1,408,151$ \\
\hline Virginia ............... & 29,646 & 115,356 & .......... & 115,356 & 31,852 & 130,208 & & 130,208 \\
\hline Other States ...... & $\ldots$ & & $\cdots$ & $\ldots$ & & 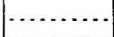 & & 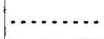 \\
\hline Total....... & $1,378,194$ & $5,345,078$ & 911,807 & $6,256,885$ & $1,233,757$ & $4,669,289$ & 947,906 & $5,617,195$ \\
\hline
\end{tabular}

The following table shows the number of squares and value of roofing slate, average value per square, and value of milled stock, by years, from 1879 to 1904, inclusive:

Values of roofing slate produced in the United States, 1879-1904.

\begin{tabular}{|c|c|c|c|c|c|}
\hline \multirow[b]{2}{*}{. } & \multicolumn{3}{|c|}{ Roofing slate. } & \multirow[b]{2}{*}{$\begin{array}{l}\text { Value of } \\
\text { milled } \\
\text { stock. }\end{array}$} & \multirow[b]{2}{*}{$\begin{array}{l}\text { Total } \\
\text { value. }\end{array}$} \\
\hline & $\begin{array}{l}\text { Number of } \\
\text { squares. }\end{array}$ & Value. & $\begin{array}{c}\text { Average } \\
\text { price per } \\
\text { square. }\end{array}$ & & \\
\hline $1879 .$. & 367,857 & $a \$ 1,231,221$ & $\$ 3.35$ & & $a \$ 1,231,221$ \\
\hline $1880 .$. & 457,267 & $a 1,529,985$ & 3.35 & & $a_{1,529,985}$ \\
\hline $1881 .$. & 454,070 & $a 1,543,838$ & 3.40 & . & $\alpha 1,543,838$ \\
\hline $1882 .$. & 501,000 & $\alpha 1,753,500$ & 3.50 & ..... & $a_{1}, 753,500$ \\
\hline $1883 .$. & 506,200 & a $1,898,250$ & 3. 75 & ............... & $a 1,898,250$ \\
\hline $1884 .$. & 481,004 & $1,843,865$ & 3.83 & $\$ 8,000$ & $1,851,865$ \\
\hline $1885 .$. & 536,960 & $1,638,467$ & 3.05 & 10,000 & $1,648,467$ \\
\hline $1886 .$. & 536,790 & $1,610,370$ & 3.00 & n.......... & $1,610,370$ \\
\hline $1887 .$. & 573,439 & $1,720,317$ & 3.00 & …....... & $1,720,317$ \\
\hline 1888. & 662,400 & $2,053,440$ & 3.10 & ........... & $2,053,440$ \\
\hline $1889 .$. & 835,625 & $2,797,904$ & 3.35 & 684,609 & $3,482,513$ \\
\hline $1891 .$. & 893,312 & $3,125,410$ & 3. 50 & 700,336 & $3,825,746$ \\
\hline $1892 .$. & 953,000 & $3,396,625$ & 3.56 & 720,500 & $4,117,125$ \\
\hline $1893 .$. & 621,939 & $2,209,049$ & 3.55 & 314,124 & $2,523,173$ \\
\hline $1894 \ldots \ldots \ldots \ldots$ & 738,222 & $2,301,138$ & 3.12 & 489,186 & $2,790,324$ \\
\hline $1895 \ldots \ldots \ldots \ldots$ & 729,927 & $2,351,509$ & 3.22 & 347,191 & $2,698,700$ \\
\hline $1896 \ldots$ & 673,304 & $2,263,748$ & 3.36 & 482,457 & $2,746,205$ \\
\hline $1897 \ldots \ldots \ldots$ & $1,001,448$ & $3,097,452$ & 3.09 & 427,162 & $3,524,614$ \\
\hline $1898 \ldots$ & 916,239 & $3,129,390$ & 3.42 & 594,150 & $3,723,540$ \\
\hline 1899. . & $1,100,513$ & $3,454,817$ & 3.14 & 507,916 & $3,962,733$ \\
\hline $1900 \ldots \ldots \ldots . . . . . . .$. & $1,194,048$ & $3,596,182$ & 3.01 & 644,284 & $4,240,466$ \\
\hline $1901 \ldots \ldots \ldots \ldots \ldots$ & $1,304,379$ & $4,114,410$ & 3.15 & 673,115 & $4,787,525$ \\
\hline $1902 \ldots \ldots \ldots \ldots \ldots$ & $1,435,168$ & $4,950,428$ & 3.45 & 745,623 & $5,696,051$ \\
\hline $1903 \ldots \ldots \ldots \ldots \ldots \ldots \ldots \ldots \ldots \ldots$ & $1,378,194$ & $5,345,078$ & 3.88 & 911,807 & $6,256,885$ \\
\hline 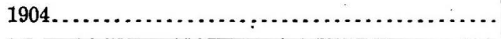 & $1,233,757$ & $4,669,289$ & 3.78 & 947,906 & $5,617,195$ \\
\hline
\end{tabular}

$a$ Estimated. 
As will be seen from the above tables, the values from 1879 to 1889 do not represent the entire value of slate quarried, as no record of slate used for mantels, school slates, pencils, tombstones, etc., was kept. In 1885 there was a large decrease in the average value per square compared with 1884 -from $\$ 3.83$ in 1884 to $\$ 3.05$ in 1885 . From 1885 to 1892 both the price and production increased in value, but owing to the financial troubles of 1893 the output decreased considerably, or from a total value of $\$ 4,117,125$ in 1892 to $\$ 2,523,173$ in 1893 . Since that time the value of the output has steadily increased, being aided largely since 1896 by export trade, until in 1903 the value of the output was $\$ 6,256,885$, the greatest yet obtained. In 1903; however, while the beginning of the year showed active operations in the slate industry, the latter part of the year showed a very decreased demand, due to strikes in the building trades. Several of the chief producing States showed decreased output of roofing slates, with increased price. This is shown in the increase of average price from $\$ 3.45$ per square in 1902 to $\$ 3.88$ in 1903 , and by a decrease of 56,974 squares-from 1,435,168 squares in 1902 to $1,378,194$ squares in 1903-while the value increased from $\$ 4,950,428$ in 1902 to $\$ 5,345,078$ in 1903 , a gain of $\$ 394,650$. In 1904 the beginning of the year showed the same unsettled state, with less demand and slightly. lower price, the total value of roofing slate decreasing $\$ 675,789$ in 1904 , or from $\$ 5,345,078$ in 1903 to $\$ 4,669,289$ in 1904 . The number of squares also decreased from 1,378,194 squares in 1903 to 1,233,757 squares in 1904, or 144,437 squares. The value of mill stock has steadily increased, the demand being continually increased by the increased use for which this class of slate is continually demanded.

\section{IMPORTS AND EXPORTS.}

IMPORTS.

The importation of slate into this country has never assumed very great proportions, and the largest quanity was of course imported before the slate quarries of the United States were fairly developed and in running order. The following tables, taken from the reports of the Bureau of Statistics, Department of Commerce and Labor, show the value of roofing slate and other slate, chiefly slate mantels, chimney pieces, etc., by fiscal years ending June 31 from 1867 to 1904 . From 1867 to 1875 the total value per annum amounted to somewhat over $\$ 100,000$, the value of the roofing slate averaging two-thirds of the whole. In 1875 there was a decided drop in the value of roofing slate imported, and since that time the imports of roofing slate have amounted to practically nothing. In the last twenty years the annual value of all imported slate has decreased from $\$ 50,739$ in 1884 to $\$ 9,436$ in 1904 .

The following table shows the value of roofing and other slates imported and entered for consumption in the United States, by fiscal years ending June 30, from 1867 to 1904 , inclusive:

Value of roofing and other slate imported and entered for consumption in the United States, 1867 to 1904, inclusive.

\begin{tabular}{|c|c|c|c|c|c|c|c|}
\hline Year. & $\begin{array}{l}\text { Roofing } \\
\text { slate. }\end{array}$ & Other. & Total: & Year. & $\begin{array}{l}\text { Roofing } \\
\text { slate. }\end{array}$ & Other. & Total. \\
\hline 1867. & $\$ 85,204$ & $\$ 37,510$ & $\$ 122,714$ & $1875 .$. & $\$ 16,342$ & $\$ 42,022$ & $\$ 58,364$ \\
\hline $1868 \ldots \ldots \ldots \ldots$ & 118,776 & 16,045 & 134,821 & $1876 \ldots \ldots \ldots \ldots \ldots$ & 2,051 & 44,266 & 46,317 \\
\hline $1869 \ldots \ldots \ldots \ldots \ldots$ & 85,364 & 19,602 & 104,966 & $1877 \ldots \ldots \ldots \ldots \ldots$ & 4 & 34,479 & 34,483 \\
\hline 1870 . & 107,521 & 19,879 & 127,400 & 1878. & 275 & 39,935 & 40,210 \\
\hline $1871 \ldots \ldots \ldots \ldots$ & 117,484 & 21,381 & 138,865 & $1879 .$. & 620 & 46,260 & 46,880 \\
\hline $1872 \ldots \ldots \ldots \ldots \ldots$ & $107,19 \cdot 2$ & 25,925 & 133,117 & $1880 .$. & 72 & 51,165 & 51,237 \\
\hline $1873 \ldots$ & 91,503 & 26,643 & 118,146 & 1881. & 2 & 46,862 & 46,864 \\
\hline $1874 \ldots \ldots \ldots$. & 80,519 & 27,519 & 108,038 & $1882 \ldots$ & 154 & 45,774 & 45,928 \\
\hline
\end{tabular}


Value of roofing and other slate imported. and entered for consumption, etc.--Continued.

\begin{tabular}{|c|c|c|c|c|c|c|c|}
\hline Year. & $\begin{array}{c}\text { Roofing } \\
\text { slate. }\end{array}$ & Other. & Total. & Year. & $\begin{array}{l}\text { Roofing } \\
\text { slate. }\end{array}$ & Other. & Total. \\
\hline $1883 \ldots \ldots . . . . . \ldots \ldots$ & $\$ 2,813$ & $\$ 44,375$ & $\$ 47,188$ & 1894. & $\$ 2,198$ & $\$ 6,342$ & $\$ 8,540$ \\
\hline $1884 \ldots \ldots \ldots \ldots \ldots \ldots$ & 16,099 & 34,640 & 50,739 & 1895. & 4,418 & 1,212 & 5,630 \\
\hline 1885. & 5,196 & 56,913 & 62,109 & 1896. & 224 & 6,191 & 6,415 \\
\hline $1886 \ldots \ldots \ldots \ldots \ldots$ & 4,366 & 60,512 & 64,878 & $1897 \ldots \ldots \ldots \ldots \ldots$ & 72 & 4,997 & 5,069 \\
\hline $1887 \ldots \ldots \ldots \ldots \ldots$ & 529 & 46,188 & 46,717 & $1898 \ldots \ldots \ldots \ldots \ldots$ & 58 & 4,866 & 4,924 \\
\hline 1888 . & 765 & 44,069 & 44,834 & 1899. & $\therefore \quad 0$ & 4,025 & 4,025 \\
\hline $1889 \ldots \ldots \ldots$ & 481 & 35,828 & 36,309 & $1900 \ldots \ldots \ldots \ldots \ldots$ & 0 & 6,998 & 6,998 \\
\hline $1890 \ldots \ldots \ldots$ & 369 & 34,602 & 34,971 & $1901 \ldots \ldots \ldots \ldots \ldots$ & 3 & 6,467 & 6,470 \\
\hline $1891 \ldots$ & 1,148 & 12,373 & 13,521 & 1902. & 0 & 4,817 & 4,817 \\
\hline $1892 \ldots \ldots \ldots \ldots \ldots$ & 1,615 & 4,952 & 6,567 & $1903 .$. & 2,221 & 7,182 & 9,403 \\
\hline $1893 \ldots \ldots \ldots \ldots \ldots$ & 1,878 & 6,671 & 8,549 & $1904 \ldots$ & 45 & 9,391 & 9,436 \\
\hline
\end{tabular}

EXPORTS.

Almost from the beginning of the slate-quarrying industry in the United States slate has contributed to the export movement of this country. In 1876, 1877, 1878, and again in 1880 a large quantity of slate was exported, the greatest part going to Great Britain and the Continent, a remarkable feature being that several cargoes were shipped directly to Welsh ports, the base of the slate supply for Great Britain. From that time until 1896 Great Britain did not take much of the product, which found an outlet in South America, the West Indies, and Australia. In fact, British Australasia has always been one of the largest foreign consumers of American slate. Until 1884 no general record of the export movement was obtainable, but as probably 90 per cent was shipped from the port of New York, the following table is given, showing the shipment of slate from that port from 1876 to 1888 . The export of manufactured slate is also shown in this table, and is almost entirely the value of school slates.

Value of exports of roofing and other slate from the port of New York from 1876 to 1888, inclusive.

\begin{tabular}{|c|c|c|c|c|c|c|c|}
\hline Year." & $\begin{array}{l}\text { Roofing } \\
\text { slate. }\end{array}$ & Other. & Total. & Year. & $\begin{array}{l}\text { Roofing } \\
\text { slate. }\end{array}$ & Other. & Total. \\
\hline $1876 \ldots$ & $\$ 377,233$ & $\$ 87,500$ & $\$ 464,733$ & 1883. & $\$ 54,063$ & $\$ 40,674$ & $\$ 94,737$ \\
\hline $1877 \ldots \ldots \ldots \ldots \ldots$ & 646,272 & 68,437 & 714,709 & $1884 \ldots \ldots \ldots \ldots \ldots$ & 90,262 & 53,021 & 143,283 \\
\hline $1878 \ldots \ldots \ldots \ldots \ldots \ldots$ & 308,852 & 88,215 & 397,067 & $1885 \ldots \ldots \ldots \ldots \ldots$ & 115,206 & 49,965 & 165,171 \\
\hline $1879 \ldots$ & 166,220 & 74,251 & $.240,471$ & 1886. & 79,064 & 40,804 & 119,868 \\
\hline $1880 \ldots$ & 220,292 & 76,709 & 297,001 & $1887 \ldots \ldots \ldots \ldots$ & 62,052 & 39,560 & 101,612 \\
\hline $1881 \ldots \ldots \ldots \ldots$ & 138,904 & 62,109 & 201,013 & $1888 \ldots \ldots \ldots \ldots \ldots$ & 116,119 & 46,142 & 162,261 \\
\hline $1882 \ldots \ldots$ & 153,318 & 68,150 & 221,468 & & & & \\
\hline
\end{tabular}

Since 1884 the Bureau of Statistics, Department of Commerce and Labor, has shown by ports and custom districts the value of the roofing slate exported by fiscal years ending June 30 , and these figures are given in the following table. No separate record has been kept of the manufactured product. 


\section{SLATE DEPOSITS AND INDUSTRY OF UNITED STATES.}

Exports of slale from the United States, showing ports and customs districts from which and to which sent, in the fiscal years 1884-1904.

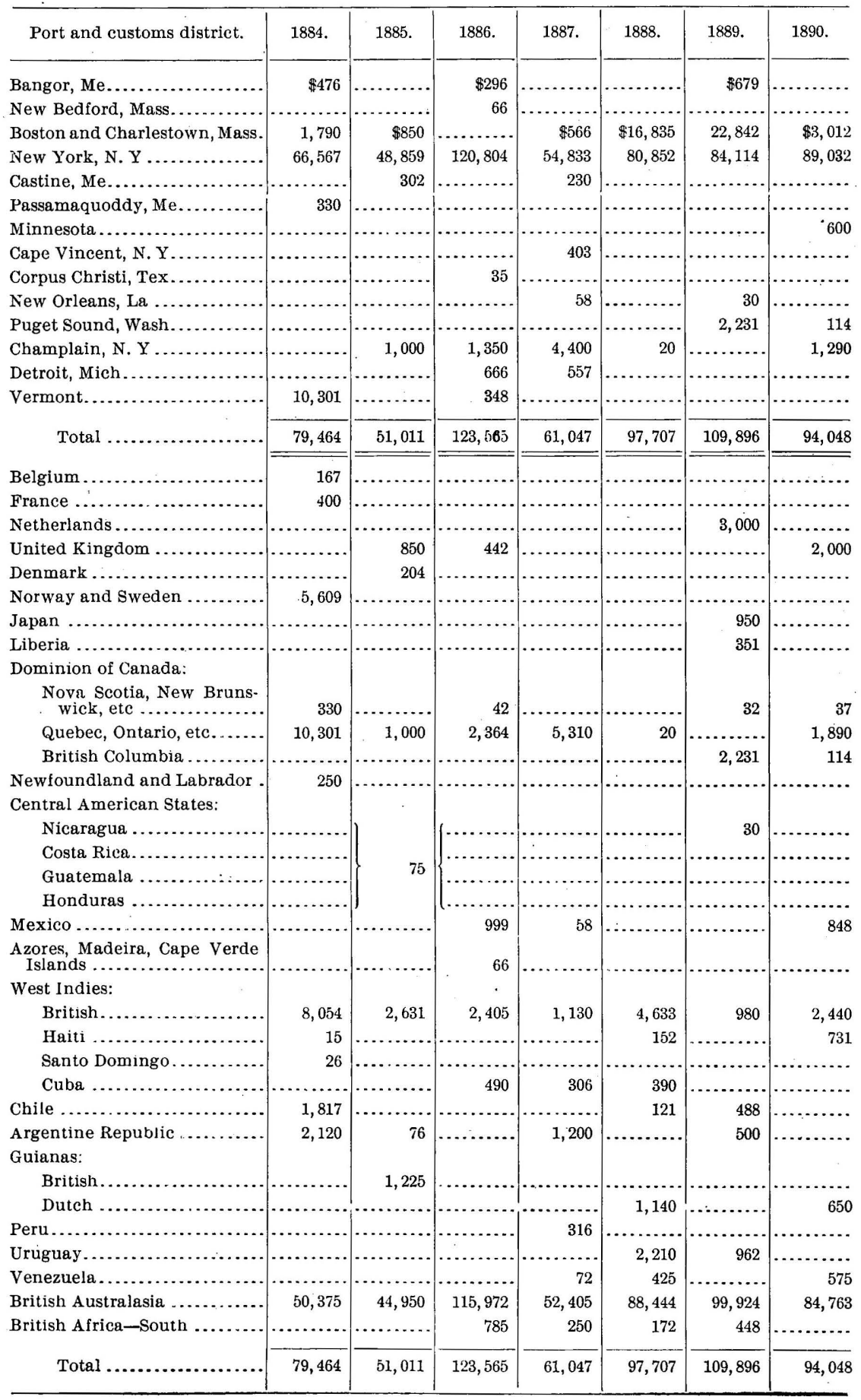


Exports of slate from the United States, showing ports and customs districts from which.and to which sent, in the fiscal years 1884-1904-Continued.

\begin{tabular}{|c|c|c|c|c|c|c|c|}
\hline Port and customs district. & 1891. & 1892. & 1893. & 1894. & 1895. & 1896. & 1897. \\
\hline Baltimore, Md... & & & & & & $\$ 9,860$ & $\$ 101,581$ \\
\hline Bangor, Me................. & $\ldots \ldots \ldots$ & $\$ 225$ & $\ldots \ldots \ldots$ & $\$ 445$ & ........ & 350 & $\cdots+\cdots$ \\
\hline $\begin{array}{l}\text { Boston and Charlestown, Mass. } \\
\text { Newport News, Va........... }\end{array}$ & $\$ 252$ & 276 & $\begin{array}{r}\$ 1,086 \\
\ldots \ldots \ldots\end{array}$ & $\mid \cdots \cdots \cdots$ & - $\$ 443$ & $\begin{array}{r}609 \\
\ldots \ldots \ldots . . .6\end{array}$ & $\begin{array}{r}1,020 \\
18,170\end{array}$ \\
\hline New York, N. Y................ & 82,303 & 56,038 & 36,306 & 19,684 & 31,092 & 242,559 & 557,099 \\
\hline Passamaquoddy, Me........... & $\ldots \ldots$ & $\ldots . .$. & $\ldots . .$. & $\ldots \ldots$ & 192 & (.......... & 120 \\
\hline 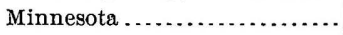 & 1,235 & & .... & $\ldots$. & $\ldots$. & (.......... & $\ldots \ldots \ldots$ \\
\hline Philadelphia, Pa............. & $\ldots \ldots \therefore$. & $\cdots$ & .... & . $\ldots \ldots \ldots$ & $\ldots$. & 2,300 & 94,865 \\
\hline Portland and Falmouth, Me.. & & & & & & & 270 \\
\hline Brazos de Santiago, Tex...... & & & 5 & ... & & & \\
\hline Corpus Christi, Tex......... & & & $\ldots$ & $\ldots$. & 105 & 174 & $\ldots$. \\
\hline New Orleans, La........ & & & & 587 & & $\cdots$ & \\
\hline Paso del Norte, Tex..... & $\ldots .$. & & & 621 & & & \\
\hline Puget Sound, Wash...... & 618 & $\ldots .$. & $\ldots \ldots \ldots$ & $\ldots \ldots \ldots$ & (n......... & $\ldots \ldots$ & $\ldots \ldots$ \\
\hline Buffalo Creek, N. Y.......... & & & 13,428 & 13,696 & 4,748 & 5,903 & 2,378 \\
\hline 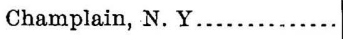 & & & 869 & 1,869 & 1,961 & 1,617 & 613 \\
\hline Detroit, Mich............... & & 975 & $\ldots$. & n....... & 65 & 2,874 & 2,427 \\
\hline Huron, Mich............ & & & 200 & & & & \\
\hline North and South Dakota...... & & & 94 & $160^{\circ}$ & ..... & & \\
\hline Vermont $. . . \ldots \ldots \ldots \ldots . .$. & & ….. & 24 & 133 & 200 & 139 & 1,569 \\
\hline Total $\ldots \ldots \ldots \ldots \ldots$ & 84,408 & 57,514 & 52,012 & 37,195 & 38,806 & 266,385 & 780,112 \\
\hline France .......... & & & & .... & $\ldots$. & 12,000 & $\cdots$ \\
\hline 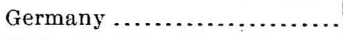 & & & & & 25 & 910 & 5,850 \\
\hline 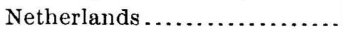 & 268 & & & & & & 2,087 \\
\hline United Kingdom .............. & 200 & 2,036 & 1,400 & 4,800 & 3,000 & 197,440 & 695,980 \\
\hline Bermuda....$\ldots \ldots \ldots \ldots$ & . & 1,195 & 1,046 & 336 & 1,550 & 2,312 & 1,395 \\
\hline $\begin{array}{l}\text { Domiņion of Canada: } \\
\text { Nova Scotia, New Bruns- } \\
\text { wick, etc ................. }\end{array}$ & $\ldots \ldots$. & 210 & 119 & 445 & 406 & 1,278 & 730 \\
\hline Quebec, Ontario, etc....... & 1,235 & 975 & 14,615 & 15,858 & 6,974 & 10,533 & 6,977 \\
\hline . British Columbia.......... & 618 & ....... & & & & & \\
\hline Newfoundland and Labrador. & & 60 & 32 & (n........ & 13 & & \\
\hline Central American States: & & & & & . & & \\
\hline $\begin{array}{r}\text { Hon } \\
\text { Mexico }\end{array}$ & & $\cdots$ & $\cdots$ & 587 & $\cdots \cdots$ & 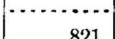 & 15 \\
\hline West Indies: & & 73 & 22 & 621 & 488 & 821 & 15 \\
\hline British . . . . . . . . . . . & 7,013 & 4,512 & ...... & 3,803 & 4,419 & 1,159 & 1,860 \\
\hline Haiti $\ldots . . . . . . . . . . .$. & 427 & 366 & ............ & 330 & (........... & $\ldots \ldots \ldots$ & $\ldots \ldots \ldots$ \\
\hline Santo Domingo............ & $\ldots \ldots$ & $\ldots \ldots$ & & .......... & 10 & $\ldots \ldots \ldots$ & \\
\hline Cuba...$\ldots \ldots \ldots \ldots$ & 16 & 160 & & 2,643 & 3,258 & 90 & $\ldots$ \\
\hline Colombia.............. & & & & & & 259 & 100 \\
\hline Guianas: & & & & & & & \\
\hline . British............... & & & & 712 & 702 & 440 & 165 \\
\hline Dutch $\ldots \ldots \ldots \ldots \ldots$ & - $\ldots .$. & 660 & 3,145 & (........... & 340 & (.......... & 1,640 \\
\hline 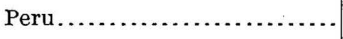 & 55 & (........... & 405 & (n........ & & $\ldots \ldots \ldots$ & ........... \\
\hline Uruguay .................. & & & & & & 417 & $\cdots$ \\
\hline East Indies-British . .......... & & & & & & 1,628 & 810 \\
\hline British Australasia .......... & 74,408 & 47,089 & 30,362 & 7,060 & 17,363 & 34,970 & 60,604 \\
\hline Hawaiian Islands............. & 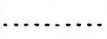 & $\cdots \cdots$ & & & & 245 & 166 \\
\hline British Africa-South ......... & 138 & 178 & 866 & (n........ & 258 & 1,883 & 1,598 \\
\hline Total & 84,408 & 57,514 & 52,012 & 37,195 & 38,806 & 266,385 & 780,112 \\
\hline
\end{tabular}


Exports of slate from the United States, showing ports and customs districts from which and to which sent, in the fiscal years 1884-1904-Continued.

\begin{tabular}{|c|c|c|c|c|c|c|c|}
\hline Port and customs district. & 1898. & 1899. & 1900. & 1901. & 1902. & 1903. & 1904. \\
\hline Baltimore, Md............ & $\$ 170,916$ & $\$ 99,083$ & $\$ 110,049$ & $\$ 135,571$ & $\$ 240,734$ & $\$ 221,933$ & $\$ 275,393$ \\
\hline Bangor, Mc............... & …. & & 577 & 1,144 & 449 & 1,170 & 30 \\
\hline Belfast, Me ................. & $\cdots \cdots$ & & & …...... & 375 & & \\
\hline Bostọn and Chariestown, Mass. & 385 & 40,622 & 65,531 & 93,972 & 48,299 & 30,273 & 29,175 \\
\hline Newport News, Va. ........... & 65,290 & 42,220 & 19,950 & 12,910 & 6,650 & 350 & \\
\hline New York, N. Y ................ & 986,638 & 968,395 & 592,288 & 388,590 & 374,264 & 207,250 & 284,750 \\
\hline Passamaquoddy, Me......... & …...... & n........ & (n......... & ........... & 160 & & \\
\hline Philadelphia & 136,916 & 205,779 & 150,254 & 236,090 & 243,701 & 120,240 & 97,247 \\
\hline ortland and $\mathrm{F}$ & & & & 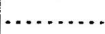 & & & 378 \\
\hline Brazos de Sant & ….... & 14 & & & & & \\
\hline Corpus & 1,761 & & & ........ & 44 & & 505 \\
\hline Paso del Norte, & ........ & … & & .......... & 20 & $\because \cdots \ldots$ & 580 \\
\hline Puge & 22 & 67 & & 1,436 & 1,343 & 1,504 & 1,445 \\
\hline an I & & 7 & & & & & \\
\hline $\operatorname{san} I$ & & & & & ....... & 1,222 & \\
\hline Arizo & ........ & ........ & . & 20 & 790 & …...... & n....... \\
\hline Buffalc & 4,141 & 6,364 & 6,584 & 19,193 & 18,014 & 35,185 & 29,034 \\
\hline$Y \ldots \ldots \ldots$ & 3,015 & 937 & 2,320 & 2,446 & 6,561 & 5,771 & 4,185 \\
\hline Detr & 854 & 129 & 1,441 & 380 & & & 669 \\
\hline Hurc & & & 424 & $\cdots \cdot$ & & & \\
\hline Mem & $\ldots .$. & & ..... & 644 & 246 & & \\
\hline Nort & 137 & & 612 & 942 & & ......... & …... \\
\hline Oswe & & & 487 & 4,915 & 3,702 & 3,714 & 3,007 \\
\hline Vermont...... & & ...... & 26 & 9 & 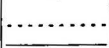 & & 317 \\
\hline Total ... & $1,370,075$ & $1,363,617$ & 950,543 & 898,262 & 945,352 & 628,612 & 726,715 \\
\hline elg & & 524 & & & & & \\
\hline Tran & …..... & …...... & ......... & …....... & .......... & 89 & 379 \\
\hline err & 82,916 & 65,974 & 17,921 & 5,180 & 1,555 & . & 1,440 \\
\hline 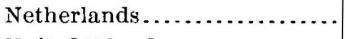 & 25 & 520 & .............. & 600 & 1,400 & .......... & 8,298 \\
\hline lom ............ & $1,213,377$ & $1,188,962$ & 813,918 & 727,088 & 731,556 & 477,251 & 515,085 \\
\hline Den & 8,150 & 25,323 & 25,437 & 43,344 & 47,957 & 17,376 & 32,512 \\
\hline 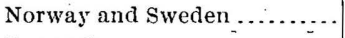 & 270 & 669 & 859 & 1,857 & 25 & …. & … \\
\hline- & 157 & 230 & 202 & 3,222 & 443 & 765 & 378 \\
\hline omi & & & & & & & \\
\hline $\begin{array}{c}\text { Nove } \\
\text { wi }\end{array}$ & & 288 & 798 & 1,269 & 532 & 1,183 & 240 \\
\hline tani at & 8,147 & 7,430 & 11,894 & 27,587 & 28,600 & 44,670 & 37,242 \\
\hline & 22 & 67 & …..... & 2,378 & 1,343 & 1,504 & 1,445 \\
\hline ewfol & & & 30 & & & & 59 \\
\hline entr & & & & & & & \\
\hline & & & & & & & 115 \\
\hline & & & & & 1,268 & 423 & \\
\hline & 1,755 & & & & & & \\
\hline Mexico & 1,872 & 330 & & 20 & 854 & 479 & 1,085 \\
\hline Miqu & 35 & & & 60 & & & \\
\hline Cas & & & & & & & \\
\hline & 2,356 & 1,400 & 2,049 & 1,067 & 6,609 & 4,724 & 4,212 \\
\hline Hai & 26 & $\cdots \cdot$ & 332 & & & . 52 & 132 \\
\hline & 673 & 16 & & & & & \\
\hline & & & & & & & 761 \\
\hline & & & 285 & & & & \\
\hline Ecuador .......... & & & & & & & 25 \\
\hline
\end{tabular}


Exports of slate from the United States, showing ports and customs districts from which and to which sent, in the fiscal years 1884-1904-Continued.

\begin{tabular}{|c|c|c|c|c|c|c|c|}
\hline Port and customs district. & 1898. & 1899. & 1900. & 1901. & 1902. & 1908. & 1904. \\
\hline \multicolumn{8}{|l|}{ Guianas: } \\
\hline Dutch & 1,325 & $\$ 2,275$ & $\$ 650$ & & $\$ 365$ & $\$ 1,399$ & \\
\hline Peru $\ldots \ldots \ldots \ldots \ldots . . . . . . . . .$. & $\ldots \ldots$ & ........... & 1,000 & & ....... & & \\
\hline Uruguay ................... & 807 & 760 & 829 & $\$ 124$ & 195 & & \\
\hline China................... & 110 & & & & & & $\$ 49$ \\
\hline East Indies-British $\therefore \ldots \ldots \ldots$ & 550 & & & n......... & 50 & ......... & \\
\hline British Australasia .......... & 44,642 & 64,434 & 71,881 & 79,319 & 121,921 & 75,976 & 120,832 \\
\hline British Oceania............ & & & & & & 1,222 & .. \\
\hline Hawaiian Islands ......... & .......... & 77 & .......... & & & $\ldots \ldots \ldots$ & ....... \\
\hline British Africa-South...... & 2,218 & 4,335 & 2,458 & 4,847 & 679 & 1,499 & 2,200 \\
\hline Portuguese Africa ......... & 42 & 3 & & r & & $\cdots \cdots \cdots$ & n........ \\
\hline Total $\ldots . .$. & $1,370,075$ & $1,363,617$ & $950, \overline{5} 43$ & 898,262 & 945,352 & 628,612 & 726,715 \\
\hline
\end{tabular}

It will be seen that the value of roofing slate exported decreased from $\$ 377,233$ in 1876 and $\$ 646,272$ in 1877 to $\$ 37,195$ in 1894 and $\$ 38,806$ in 1895 . In 1896 , however, owing to strikes in the Welsh quarries, the United States gained a foothold again in England and in the English colonies. The value of slate exported in 1896 was $\$ 266,385$; in $1897, \$ 780,112$, and the greatest valuation was reached in 1899 , when the figures were $\$ 1,363,617$. The value of the exported slate in 1904 was $\$ 726,715$, showing that, although the strikes are practically over, the demand for American slate remains. However, in the last two years French slates of a small size have found considerable market in England at less price than American slates. Great Britain and Ireland, British Australasia, the Dominion of Canada, and Denmark are, in the order named, the largest receivers of American slate. 


\section{BIBLIOGRAPHY OF SLATE.}

The following bibliography is divided into three sections. The first includes only works of a general character, the second special scientific papers and memoirs, and the last works of an economic character.

\section{WORKS OF A GENERAL CHARACTER.}

Campbell (Donald). Slate.

Encycl. Britannica, 9th ed., vol. 22; 1887.

Chamberlin (T. C.), and Salisbury (R. D.). Geology.

Vol. 1. Geologic processes and their results. Slaty cleavage and slate, pp. 420-422, fig. .364; New York, 1904.

Geikie (Archibald). Cleavage.

In article "Geology, VI," Encycl. Britannica, 9th ed., vol. 10; 1887.

Geikie (Archibald). Text-book of Geology.

Vol. 1. Cleavage, pp. 417-419, 684-687, 4th ed.; London, 1903.

Green (H. H.). Geology. Part I, Physical Geology; London, 1882.

Sec. 7. Some structures impressed on rocks after their formation; pp. 269-279, figs. 100-103.

Harker (Alfred). Petrology for students; an introduction to the study of rocks. under the microscope; Cambridge, England, 1895. Chap. 17. Argillaceous rocks. 2d ed., 1897.

Kalkowsky (ERNst). Elemente der Lithologie für Studirende bearbeitet; Heidelberg, 1886. Familie der Thonschiefer, pp. 255-265.

Rosenbusch (H.). Elemente der Gesteinslehre; Stuttgart, 1898. Thonschiefer, pp. 422-429. Phyllite oder Thonglimmerschiefer, pp. 429-438. Analyses, pp. 425, 433.

Rotr (Justus). Allgemeine und chemische Geologie; Berlin, 1879-1890. Analyses, vol. 2, pp. 585, 593 .

Zirkel (Ferdinand). Lehrbuch der Petrographie, 2d ed.; Leipzig, 1894. Vol. 3, Phyllit, pp. 295-319; 'Thonschiefer, pp. 744-753.

SPECIAL SCIENTIFIC PAPERS AND MEMOIRS.

Adie (Alexander J.). On the expansion of different kinds of stone from an increase of temperature, with a description of the pyrometer used in making the experiments.

Trans. Roy. Soc. Edinb., vol. 13, 1836. [Slate from Penrhyn quarry, Wales, expands .00000576 of an inch linear for $1^{\circ} \mathrm{Fahr}$.]

Anger (F. A.). Mikroskopische Studien über klastische Gesteine.

Min. Mittheil. ges., v. G. Tschermak; vol. 3, 1875, pp. 153-174.

BAYLEY (W. S.). Slate from Monson, Piscataquis County, Maine.

Bull. U. S. Geol. Survey No. 150. The educational series of rock specimens collected and distributed by the U. S. Geological Survey, 1898, pp. 308-313. 
Barrois (Charles). Recherches sur les terrains anciens des Asturies et de la Galice; Lille, 1882.

Phyllades du terrain Cambrien, pp. 22-28.

BAUR (—— Ü̈ber die Lagerung der Dachschiefer, über Wetzschiefer und über die von der Schichtung abweichende Schieferung der Thonschiefer im nordwestlichen Theile des Dürener Bergamts-Bezirks.

Archiv für Min. Geogn., etc. Von Karsten und von Dechen, vol. 20, p. 351, pl. 5; Berlin, 1846.

BfCKer (G. F.). Finite homogeneous strain, flow, and rupture of rocks. Bull. Geol. Soc. Am., Rochester, N. Y., vol. 4, 1893, p. 13.

BECKER (G. F.). Schistosity and slaty cleavage. Journal of Geology, Chicago, vol. 4, May-June, 1896, p. 429.

BeCKer.(G. F.). Experiments on schistosity and slaty cleavage. Bull. U. S. Geol. Survey, No. 241, 1904.

Bischof (Gustav). Lehrbuch der chemischen und physikalischen Geologie, 2d ed.; Bonn, 1866.

Cause of discoloration, vol. 2, pp. 350-351, footnote.

Chance (H. M.). The slate quarries [on the Delaware and Lehigh rivers in Pennsylvania] in 1875; with four cross sections.

Second Geol. Survey Pa., Report of Progress D3; vol.1, Lehigh and Northampton counties, pp. $148-160,1883$.

Credner (G. R.). Das Grünschiefersystem von Hainichen im Königr. Sachsen. Zeitschr. für ges. Naturwissenschaften, vol. 47; Berlin, 1876.

Dale (T. Nelson). The Rensselaer grit plateau in New York.

Thirteenth Ann. Rept. U.S. Geol. Survey, 1891-92. The structure in black slate at the Lebanon Springs quarry, pp. 319-321 and Pl. C.

DALE (T. NeLson'). The slate belt of eastern New York and western Vermont. Nineteenth Ann. Rept. U. S. Geol. Survey, 1899, pt. 3, pp. 153-307.

DaubréE (A.). Expériences sur la schistosité des roches et sur les déformations des fossiles, corrélatives de ce phenomène; conséquences géologiques de ces expériences.

Bull. Soc. Géol. France, 3d ser., vol. 4, p. 529, 1876. Also Comptes Rendus Acad. des Sciences, vol. 82, pp. 710-716; Paris, 1876.

DAubrÉE (A.). Études synthétiques de géologie expérimentale, pp. 333-336, 392-432, 442-445; Paris, 1879.

De la Beche (Henry T.). Geological Observer, 2d ed.; London, 1853.

ECKEL (EDw IN C.). On a California roofing slate of igneous origin. Jour. Geol., vol. 12, pp. 15-24, No. 1, 1904.

ECKel (EDwin C.). On the chemical composition of American shales and roofing slates.

Jour. Geol., vol. 12, pp. 25-29, No. 1, 1904.

Geinitz (E.). Der Phyllit von Rimogne in den Ardennen. Tschermaks Min. Mittheil. (neue folge), vol. 3, pp. 533-540, 1880.

Gosseler (J.) Les schistes de Fumay. Annales de la Société géologique du Nord, vol. 10, pp. 63-86; Lille, 1884.

Gosselet (J.). L'Ardenne.

Mémoires pour servir à l'explication de la carte géologique détaillée de la France, pp. 26-28, 33-35, 54, 60-62; Paris, 1888.

Gosselet (J.) et Malaise. Sur la terminaison occidentale du massif ardoisier de Fumay.

Ann. Soc. Géol. du Nord, vol. 22, pp. 59-64; Lille, 1898.

Grubenmann (U.). Die kristallinen Schiefer. Part I; Berlin, 1904.

[Metamorphism in schist and slate.] Struktur p. 71, textur p. 84, kluftung p. 92.

GüMBEL. Geognost. Beschreib. des Fichtelgebirges; Gotha, 1879. 
HALL (C. W.). Keewatin area of eastern central Minnesota. Bull. Geol. Soc. Am., vol. 12, p. 362, pl. 31, fig. 1. The clay slates, A ug., 1901.

HARKER (Alfred). On slaty cleavage and allied rock structures, with special reference to the mechanical theories of their origin. Rept. Brit. Assoc. Adv. Science (1885), 1886.

Harkness (Robert) and Blythe (John). On the cleavage of the Devonians of the southwest of Ireland. Ldinbe New Phil. Jour., new series, vol. 2, No. 4, Oct., 1855.

Hawes (G. W.). Clay slate (argillite). Geology of New Hampshire, by C. H. Hitchcock and others, vol. 3, pt. 4, pp. 236-238.

Hopkins (W.). On the internal pressure to which rock masses may be subjected, and its possible influence on the production of the laminated structure. Trans. Camb. Phil. Soc., vol. 8, pp. 456-470; Cambridge, England, 1849.

Hoskins (L. M.). Flow and fracture of rocks as related to structure. Sixteenth Ann. Rept. U. S. Geol. Survey, 1894-95, pt. 1, 1896. (Cleavage and fissility, pp. 868-874.)

Hutchingis (W. Maynard). Clays, shales, and slates. Geol. Mag., dec. 4, vol. 3, No. 7, p. 309, and No. 8, p. 343. On slates, pp. 312-314, 343, 344; London, 1896.

Hutchings (W. MaYnard). Ash slates of the Lake district. Geol. Mag., London, 1892.

InostranzefF (A.). Studien über metamorphosirte Gesteine im Gouvernement Olonez (Russia).

Thonschiefer, pp. 137-144; Leipzig, 1879.

JANNETAZ (ED.). De la propagation de la chaleur dans les corps; de ses relations avec la structure des minéraux, (2) le métamorphisme des roches.

Bull. Soc. géol. France, 3d ser., vol. 3, pp. 499-510. Experiments with slate, p. 505. See also vol. 2, p. 264.

J ANNETAZ (ED.). Relation entre la propagation de la chaleur et l'élasticité sonore dans les roches et dans les corps cristallisés.

Bull. Soc. géol. France, 3d ser., vol. 5, pp. 410-426, 1877. Experiments with slate, p. 416.

Jannetaz (ED.). Mémoire sur les connexions de la propagation de la chaleur avec leurs différents clivages et avec les mouvements du sol qui les ont produits. Bull. Soc. géol. France, 3d ser., vol. 9, p. 196, 1880-81.

Jannetaz (ED.). Mémoire sur les clivages des roches (schistosité, longrain) et sur leur reproduction.

Bull. Soc. géol. France, 3d ser., vol. 12, p. 211, 1883-84.

KING (WILLIAM). On jointing and its relation to slaty cleavage. Trans. Roy. Irish Acad., vol. 25, 1875.

Lauger (Auguste). Le Clivage des roches. Bull. Soc. Géol. de France (2), vol. 12, 1854-1855. pp. 363-368.

LeITH (C. K.). Rock cleavage.

Bull. U. S. Geol. Survey No. 239, 1905. Summary statement of secondary rock cleavage, p. 135 . Comparison of present statement with previous ones as to secondary cleavage, p. 140. Original cleavage, p. 143.

Lesley (J. P.). A summary description of the geology of Pennsylvania. Geol. Surv. Pa., Final Rept., vol. 1 (The southern or Peach Bottom phyllite belt, pp. 136-141, 555, 556. Chaps. 45-49, Formation No. 3 and the roofing-slate beds); Harrisburg, 1892.

LORET\% (H.). Ueber Schieferung.

Bericht über die Senckenbergische naturforschende Gesellschaft, pp. 61-116, 1879-80; Frankfurt a. M., 1880 .

LoRETz (H.). Ueber Transversalschieferung und verwandte Erscheinungen in Thüringischen Schiefergebirge.

Jahrb. Königl. Preuss. geol. Landesanstalt und Bergakademie, pp. 258-306 and pl. 7 (1881); Berlin, 1882.

MallaRd (E.). Sur l'examen microscopique de quelques schistes ardoisiers. Bull. Soc. minéralogique de France, vol. 3, No. 4, p. 101, 1880. 
Maw (GEorge). On a new section of the Cambrian rocks in a cutting of the Llanberis and Carnarvon Railway and the banded slates of Llanberis.

Geol. Mag., vol. 5, pp. 121-125 and pls. 6, 7; London, 1868.

MAW (GEORGE). On the disposition of iron in variegated strata.

Quart. Jour. Geol. Soc., vol. 24 (p. 379 on variegated Cambrian slates, pl. 14, figs. 29, 31, 32); London, 1868.

McCreath (Andrew S.). Analysis of Peach Bottom slates.

Geol. Survey of Pennsylvania, Report of Progress for 1877, vol. CCC, pp. 269, 270; Harrisburg, 1880.

Merrill (George P.). A treatise on rocks, rock weathering, and soils.

Analysis of Peach Bottom slate and remarks on their weathering, with analyses showing the incidental chemical changes. New York, 1897.

Müller (Friedrich ERnst). Die normalen Schiefer des Hennbergs.

In article: Die Contacterscheinungen an dem Granite des Hennbergs bei Weitisberga. Nenes Jahrb. für Min., Geol., etc., vol. 2, 1882, pp. 205-248.

Phillips (JонN). On a group of slate rocks ranging east-southeast hetween the rivers Lune and Wharfe, from near Kirby, Lonsdale, to near Malham; and on the attendant phenomena.

Trans. Geol. Soc. London, 2d ser., vol. 3, pt. 1, pp. 16, 17, on the stratification of slate; p. 8, on "bate;" London, 1829.

Phillips (Jors). Report on cleavage and foliation in rocks, and on the theoretical explanation of these phenomena.

Report Twenty-sixth Meeting Brit. Assoc. Adv. Science (Cheltenham, 1856), pt. 1, pp. 369-396; London, 1857.

Phillips (J. Arthur). On the chemical composition and microscopic enstitution of certain Cornish rocks.

Analyses and description of Delabole roofing slate, London, Edinb., and Dublin Philos. Mag. and Jour. Sci., th ser., No. 271, pp. 95, 96, Feb., 1871.

Prinz (W.). La déformation des matériaux de certains phyllades ardennais n'est pas attributable au "flux" des solides.

Bull. Soc. Belge de géol., etc., vol. 19, 1905, pp. 449-482; Pls. XIII, XIV.

RAMSAY (A. C.). The geology of North Wales.

Memoirs of the Geological Survey of Great Britain and of the Museum of Practical Geology, $a$ vol. 3, 2d ed., pp. 102, 103, 179, 190, 230-233, 237-239, 216, 247; London, 1881.

Reade (T. Mellard) and Holland (Philip). The phyllarles of the Ardennes compared with the slates of North Wales.

Proc. Liverpool Geol. Soc., vol. 8, pt. 1, pp. 274-293, 1899; pt. 2, pp. 463-479, 1900.

Reade (T. Mellard) and Holland (Philip). The green slates of the Lake district, with a theory of slaty structure and slaty cleavage.

Proc. Liverpool Geol. Soc. (1900-1901), 1901, pp. 101-127.

Reade (T. Mellard). The evolution of earth structure, with a theory of geomorphic changes. London, 1903.

Chap. XIX, On slaty cleavage.

Renard (A. F.) Recherches sur la composition et la structure des phyllarles ardennais.

Bull. Mus. roy. d'hist. nat. de Belgique, vol. 1, No. 3, 1882, p. 215, Chem. Analyses; vol. 2, 1883, pr. 127-152 and pl. 6, vol. 3, 1884, pp. 231-268 and pls. 12, 13, Microscopic examinations.

Rogers (Henry Darwin). Geology of Pennsylvania; a government survey.

Slate and slaty cleavage, vol. 1, pp. 188, 247, 249, and vol. 2, pp. 902-916; Philadelphia, 1858.b

Rosenbusch (H.). Die Steiger Schiefer und ihre Contactzone an den Cranititen von Barr-Andlau und Hohwald.

Abh. zur Geol. Specialkarte von Elsass-Lothringen, vol. 1, pp. 84-125; Strassburg, 1877.

Rosenbusch (H.). Microscopical physiography of the rock-making minerals.

(Transl. by Joseph P. Iddings, New York, 1889.)

Slate needles, p. 149 and pl. 15, fig. 4. A fourth edition of original, 1904-5. 


\section{SLATE DEPOSITS AND INDUSTRY OF UNITED STATES.}

SANDERS (R. H.). The geology of Lehigh and Northampton counties.

Second Geol. Survey of Pennsylvania, Report of Progress D3, vol. 1, chap. 2, The Slate Region (figs. on pp. 95, 119, 127, and pl. 1), 1883.

Saugr (A.). Rutil als mikroskopischer Gemengtheil in der Gneiss und Glimmerschieferformation, sowie als Thonschiefernädelchen in der Phyllitformation. Neues Jahrb. für Min., Geol., etc., vol. 1, pp. 227-238, 1881.

Sauvage (-). Recherches sur la composition des roches du terrain de transition. Annales des Mines, 4th ser., vol. 7, pp. 411-462, Paris, 1845. Also Comptes Rendus, vol. 21, pp. 228-233, 1845.

SEDGWICK (ADAM). Remarks on the structure of large mineral masses, and especially on the chemical changes produced in the aggregation of stratified rocks during different periods after their deposition.

Trans. Geol. Soc. London, 2d ser., vol. 3, pt. 3, pp. 461-486, 1835. Abstract in Proc. Geol. Soc. London, vol. 3, No. 40, p. 181, 1835.

Selwyn (A. R. C.) and Jukes (J. B.) Sketch of the structure of the country extending from Cader Idris to Moel Siabod, North Wales.

Quart. Journ. Geol. Soc. London, vol. 4, 1848, pp. 300-312.

Sharpe (Danier). On slaty cleavage.

(Second communication) Quart. Jour. Geol. Soc. London, vol. 5, pp. 111-129, 1849.

Sorby (Henry Clifton). On the origin of slaty cleavage.

Edinb. New Phil. Jour., vol. 55, No. 109, pp. 137-148, July, 1853.

Sorby (Henry Clifton). On the theory of the origin of slaty cleavage.

Lond., Edinb., and Dublin Phil. Mag., 4th ser., vol. 12, No. 77, pp. 127-129, Aug., 1856.

Sorby (Henry Clifton). On some facts connected with slaty cleavage.

Rept. British Association Adv. Science, p. 92, 1857.

Sorby (Henry Clifton). On the structure and origin of noncalcareous stratified rocks.

Quart. Jour. Geol. Soc. London, vol. 36. On shales and plates, pp. 67-77, 1880.

SPRING (W.) Sur les conditions dans lesquelles certains corps prennent la texture schisteuse.

Arch. des sciences phys. et nat. de Genève (4), vol. 13, pp. 329-341, 1893.

Teall (J. J. Harris). A faulted slate.

Geol. Mag., new ser., dec. 3, vol. 1, pl. 1, London, Jan., 1884.

Tyndall (ЈонN). Comparative view of the cleavage of crystals and slate rocks.

A lecture at Roy. Inst., June, 1856, Lond., Edinb., and Dublin Phil. Mag., 4th ser., vol. 12, No. 76, pp. 35-48, July, 1856. (See also Proc. Roy. Inst.)

UmLauft (W. L.). Beitrïge zur Kenntniss der Thonschiefer.

Jahresb. des Natur. Histor. Vereines "Lotos" (1876), 29 pp.; Prague, 1876.

Van Hise (Charles Richard). Principles of North American pre-Cambrian geology, Sec. III, Cleavage and fissility.

Sixteenth Ann. Rept. U. S. Geol. Surv. (1894-5), pt. 1, 1896, pp. 633-668. Sec. 3, Slate and mieaslate, p. 705.

Van Hise (Charles Richard). Deformation of rocks, cleavage, and fissility; studies for students.

Jour. Geol., vol. 4, pp. 195, 312, 449, 593; Chicago, Feb.-Aug., 1896.

Van Hise (Charles Richard). A treatise on metamorphism.

Mon. U. S. Geol. Survey, vol. 47, 1904. Theory of recrystallization, pp. 690 694. Rock flowage, pp. 748-762. Slate and schist, pp. 778, 779. Mud family, pp. 886-892. Shale family, 892-894. Pelite-slate, pp. 894-898.

Walcott (Charles D.). Cambrian age of the roofing slates of Granville, Washington Co., New York.

Proc. Am. Assoc. Adv. Sci., vol 35, pp. 220-221, Aug., 1886, Salem, 1887.

Williams (George H.). Anatase from the Arvon slate quarries, Buckingham Co., Virginia.

Am. Jour. Sci., 3d ser., vol. 42, 1891, pp. 431-432. 
Zirkel (F.). Über die mikroskopische Zusammensetzung von Thonschiefern und Dachschiefern.

Poggendorff's Annalen, vol. 144, 1871, p. 319.

WORKS OF AN ECONOMIC CHARACTER.

Bennetr (H. D.) [U. S. Vice-Consul at Nantes, France]. The slate quarries of Angers.

U. S. Consular reports No. 24, p. 115, Jan., 1891.

Böttinger (C.). Zusammensetzung und Verhalten von Dachschiefer. Chem. Zeitung, vol. 19, p. 19, 1144, 1895.

Bower (JoHs). Slate quarries as an investment [England], 1865.

Brunner (H.). Valuation of roofing slates.

Abstract in English from Wochenschrift für Pharm., 1889, in Jour. Soc. Chem. Indust., vol. 9, -p. 393, London, Apr. 30, 1890.

Campbell (J. L. \& H. D.). The Snowden slate quarries. The Virginias, vol. 5, p. 162, 163, 1884 .

Coons (Altha T.). Slate. Mineral Resources U. S., calendar year 1904, U. S. Geol. Survey, 11. 825-830.

Crawford (J. J.). California slate and slate industry. Twelfth Report State mineralogist, California State Mining Burean, 1894. (See also Eighth Rept.)

Dale (T. Nelson). The slate industry at Slatington, Pa., and Martinsburg, W. Va. Bull. U. S. Geol. Survey, No. 213. Contributions to economic Geology (1902), pp. 361-364, 1902.

Dale (T. Nelson). Note on Arkansas roofing slate.

Bull. U. S. Geol. Survey, No. 225 Contributions to economic Geology, 1903-1904, pp. 414-416.

Dale (T. Nelson). Slate in Maine, Pennsylvania, Vermont (northern), Virginia, and West Virginia.

Bull. U. S. Geol. Survey, No. 260. Contributions to economic Geology, 1904-1905, pp. 486-488.

DAvies (D. C.). A treatise on slate and slate quarrying, scientific, practical, and commercial, 3d ed., London, 1887, p. 186.

$\mathrm{D}_{\mathrm{AX}}$ (DAvid T.). Report on mineral industries in the United States at the Fleventh Census, 1890.

Slate, distribution of quarries, production, labor, and wages, p. 66i2-66in, 1892.

DAY (DAvid T.). Mineral resources of the United States, calendar year 1893, U.S. Geol. Survey.

Slate in U. S., p. 549; in Great Britain, p. 551, 1894.

Day (David T.). Slate.

Mineral resources of the U. S., calendar year 1900, U. S. Geol. Survey, pp. 676-682.

Mineral resources of the U. S., calendar year 1901, U. S. Geol. Survey, pp. 660-663.

Mineral resources of the U. S., calendar year 1902, U. S. Geol. Survey, pp. 687-691.

Mineral resources of the U. S., calendar year 1903, U. S. Geol. Survey, pp. 776-780.

DAY (WILliam C.). The slate industry.

Sixteenth Ann. Rept. U. S. Geol. Survey, pt. 4. Mineral resources U. S. (1894), nonmetallic products, pp. 473-482, 1895.

Day (Wiliam C.). Slate and the slate industry.

Seventeenth Ann. Rept. U. S. Geol. Survey, pt. 3, continued. Minerul resources U. S. (1895), nonmetallic products, pp. $770-775,1896$.

Day (William C.). Slate.

Eighteenth Ann. Rept. U. S. Geol. Survey, pt. 5, continued. Mineral resources U. S., 1896, Jp. 992-1011.

Nineteenth Ann. Rept. Geol. Survey, pt. 6, continued. Mineral resources U. S., 1897, pp. 248-264. Twentieth Ann. Rept. U. S. Geol. Survey, pt. 6, continued. Mineral resources U. S., 1898, pp. 292-336.

Twenty-first Ann. Rept. U. S. Geol. Survey, pt. 6, continued. Mineral resources U. S., 1899, pp. $344-352$.

Ecrel (Edwin C.). The slate deposits of California and Utah.

Bull. U. S. Geol. Survey No. 225. Contributions to economic geology 1903, pp. 417-422.

Bull. 275-06-11 


\section{4}

Frazer (Persifor, jr. ). Geology of Lancaster County, Pennsylvania. Second Geol. Survey Penna.,.Rept. of Progress, 1877, Vol. CCC; Harrisburg, 1880. Roofing slate quarries of Lancaster and York counties, pp. 179-190, pls. 7, 8.

Fresenius (R.). Ueber die Prüfung der Dachschiefer auf den Grad ihrer Verwitterbarkeit. Zeitschr. für Analyt. Chemie, vol. 7, pp. 72-78; Wiesbaden, 1868.

Hawes (George W.), Merrill (George P.), and others. Special reports on building stones of the United States for. 1880 . Tenth Census, vol. 10, 1884. Slate, pp. 38-11, 50-57, 60-77, 168-174, 180-181.

Hayes (C. W.). Slates of the Rockmart formation in Georgia. Geologic Atlas U. S., folio 78, U. S. Geol. Survey, 1902.

Hermann (O.). Steinbruch industrie und Steinbruch geologie; Berlin, 1899. Dachschiefer, pp. 64, 146, 176, 272-277; Fruchtschiefer, pp. 278-283.

Hitchcock (Charles H.). Roofing slate in Maine. Preliminary Rept. Nat. Hist. and Geol., State of Maine, pp. 316-319, 1361.

Hitchcock (Charles H.). Roofing slate in Piscataquis and Penobscot counties, Me. Second Ann. Rept. Nat. Hist. and Geol., Maine, pt. 2, Geology. Monson, p. 280; Shirley, p. 282; Paten, p. 360, 1862.

JAckson (C. T.). On the Waterville, Me., slates. Am. Jour. Science, vol. 41, p. 163, 164, 1841; also Trans. Assoc. Am. Geol., p. 16, 1843.

Hull (EDward). A treatise on the building and ornamental stones of Great Britain and foreign countries; London, 1872.

Kítтh (Arthur). Slates of Little Pigeon River, Tennessee. Geologic Atlas U. S., folio 16, U. S. Geol. Survey, 1895, p. 6.

Kellow (Joseph). The slate trade of North Wales [England], 1868.

KNoch (A.). Der Dachschiefer; Berlin, 1895.

Langley (Alfred A.) and Bellamy (Charles J.). Slate quarrying in the Festiniog district, North Wales.

Proc. Inst. Civ. Eng., vol. 44, p. 211 and pl. 21; London, 1876.

Lindgren (W.), and Turner (H. W.) Roofing slates in Eldorado County, Cal. Geologic Atlas U. S., folio 3, U. S. Geol. Survey, 1891.

Mathews (Edward B. ). An account of the character and distribution of Maryland builbing stones, together with a history of the quarrying industry.

Maryland Geol. Survey, vol. 2, 1898. Slate: The Peach Bottom area, pp. 214-231; Ijamsville, p. 231, 232; prices, p. 239.

Merrill (George P.). The collection of building and ornamental stones in the U. S. National Museum. A handbook and catalogue.

Ann. Rept. Smithsonian Institution, June 30, 1886. Pt. 2. Early history of slate industry in U. S., p. 291; the slates of the various States and Territories, pp. 466-471.

Merrill (George P.). Stones for building and decoration. The slates, pp. 17o198; 3d ed., New York, 1903.

Merrill (George P.). Among the Pennsylvania slate quarries. Scientific American; Supp., vol. 27, p. 10874, No. 681, 1889.

Merrill (George P.). Stone. Twelfth Census. Special reports on mines and quarries (1902), 1905. Slate, pp. 802-805.

Merrill (Frederick J. H.). Mineral resources of New York State.

Bull. N. Y. State Museum, vol. 3; Albany, 1895. Geology and geographic distribution of building stone in New York, by John C. Smock, revised by F. J. H. Merrill, Slate, pp. 421-423.

Merriman (MANSfield). The strength and weathering qualities of roofing slates. With discussion.

Trans. Am. Soc. Civ. Eng., vol. 27, No. 3, pp. 331-349, Sept., 1892, and No. 6, Dec. 1892, p. 685; also vol. 32, p. 529-539, 1894.

Merriman (Mansfinld). The slate regions of Pennsylvania.

Stone, vol. 17, pp. 77-90, New York, 1898 (has a máp showing general boundaries of Lehigh, " hard vein," Pen Argyl, and Bangor regions). 
Müller (H.). Uẻber die Dachschiefer in der Nähe von Lössnitz. Jahrb. für den Berg-und Hüttenmann, 1854, pp. 190-233.

Nevins (J. Nelson). Roofing-slate quarries of Washington County, N. Y. Fifty-third Ann. Rept. N. Y. State Museum, 1899, vol. 1, pp. 135-150, Albany, 1902.

Nivort (Edmond). Notions élémentaires sur l'industrie dans le département des Ardennes (France), 1869.

Parrisrr. History of the slate trade in America. Am. Jour. Mining. II, 1866-1867. In Johns Hopkins Library.

Patrison (S. R.). Slate and slate quarries geologically and commercially considered. Letters to the Mining Journal (Eng.), 1866.

Perkins (George H.). Rept. State Geologist on the mineral industries of Vermont, $1899-1900$. Slate, pp. 17-30.

Perkins (George H.). Rept. State Geologist on the mineral industries and geology of certain areas of Vermont. (IV), 1903-1904. Slate, pp. 47-51, Montpelier, 1904.

Poncelet (J. B.). Des gîtes ardoisiers de l'A Ardenne; Bruxelles, 1848.

REVERdin (F.) and DE LA HARPE (C.). The examination of roofing slates.

Chem. Zeitung, vol. 14, pp. 64-65, 94-95, 126-127. Abstract in English in Jour. Soc. Chem. Industry, vol. 9, p. 394, London, $\Lambda$ pr. 3n, 1890.

Richardson (C. H.). The terranes of Orange County, Vt. Slate, pp. 77-81, pls. 9, 9 A, Rept. State Geologist Vt., 3d of new series (1901-1902) 1902.

Rogers (William B.). Reprint of annual report and other papers on the geology of the Virginias (posthumous). On the roofing slate of Buckingham Co., p. 78, 79. On that of Fauquier Co., p. 460, 461. New York, 1884.

Sauvage et Buvignier. Statistique minéralogique et géologique du département des Ardennes (France), 1842.

Shaler (N. S.). Slates, description of quarries and quarry regions. Tenth Census U. S., 1880, vol. 10, pt. 2, report on the building stones of the United States and statistics of the quarry industry, pp. 168-174.

Smith (Thomas Cooper). Slate quarries in Wales, 1860. Two later editions.

SPEer (F. W.). Quarry methods: The working of slate. Tenth Census U. S., 1880, vol. 10, pt. 2, p. 38.

Watrin (N.). Les ardoisières des Ardennes. Description et exploitation du schiste ardoisier, fabrication des ardoises, lever des plans d'ardoisières. Charleville, 1898.

Williams (J. Francis). Tests of Rutland and Washington County slates. (Purple and green from Fair Haven, Vt. Red from Granville, N. Y.) Van Nostrand's Engineering Magazine, vol. 31, pp. 101-103, July-Dec., 1884.

[ANonymous]: The slate quarries of North Wales. Reprint of letters to Carnarvon Herald, 1873. 


\section{GLOSSARY OF GEOLOGICAL AND SLATE-QUARRY TERMS.}

As this bulletin is intended primarily for the use of persons unfamiliar with geological science, a number of the geological terms used in it, whose meaning is not selfevident, are here explained, and for the benefit of geologists who may have occasion to use the book some of the terms in use among slate quarrymen are also translated into scientific ones.

AGgREgate Polarization. The optical property possessed by a thin section of slate cut transverse to its cleavage, which causes it, when viewed through a microscope under polarized light, to appear like a crystal of mica cut across its mineral cleavage. The aggregate polarization of a slate is due to the parallelism of the flakes of mica in the slate, and this, when marked, shows it to be a mica-slate arid not a clay-slate. A very brilliant aggregate polarization, coupled with regularity in size of particles, indicates a high grade of fissility.

ANTICLINE. The areh part of a folded bed.

ANTICLINORIUM. A mountain mass arch-shaped in its general internal structure.

AUTHIG ENous. Minerals originating chemically within a rock are called authigenous.

BACK JoINT. Joint plane more or less parallel to the strike of the cleavage and frequently vertical.

BED. A continuous mass of material deposited under water at about one time.

BLIND JoINT. Obscure bedding plane.

Воттом JoINT. Joint or bedding plane horizontal or nearly so.

BRECCIA. Rock made up of angular fragments produced by crushing and then recemented by infiltrating mineral matter.

BRECCIATED. Applièd to a rock made up of angular fragments but not transported.

CLAstic. Constituted of rocks or minerals which are fragments derived from other rocks.

Cleave. Slaty cleavage.

Conformity. When two beds overlie in parallelism without any disturbance of the crust having affected the first one before the deposition of the second, they are said to be in conformity.

Diagonal Jornts. Joints diagonal to the strike of the cleavage.

DiP. The degree and the direction of the inclination of a bed, cleavage plane, joint, etc.

DiP JorNT. Vertical joints about parallel to the direction of the cleavage dip.

DIKE. Molten material erupted through a narrow fissure.

END JOINT. Vertical joint about parallel to direction of the cleavage dip.

Erosion. The "wear" of a rock surface by natural mechanical or chemical agencies.

False Cleavage. A secondary slip cleavage superinduced on slaty cleavage. (See p. 24 and Pls. $\mathrm{VI}, \mathrm{XI}, A$.

FaUlT. A fracture resulting in a dislocation of the bedding or cleavage, one part sliding up or down, or both changing positions along the fracture.

Flints. A term applied alike to quartz veins or beds or quartzite.

Formation. A larger group of beds possessing some common general characteristics or fossil forms differing from those of the beds above and below.

GraIN. An obscure vertical cleavage usually more or less parallel to the end or dip joints.

HARDS. Term applied to beds of quartzite or quartzitic slate.

HCL. Hydrochloric or muriatic acid.

Hog Backs. Shear zones. (See p. 29 and Pl. VII.)

Isochina L. Folds with sides nearly parallel are said to be isoclinal.

Matrix. Term used in microscopic descriptions of slate, etc., to denote the chief substance of the slate itself, apart from the various mineral particles or crystals it may inclose.

Metamorphism. The process, partly physical, partly chemical, by which a rock is altered in the molecular structure of its constituent minerals and frequently in the arrangement of its particles.

OVERLAP. Where, owing to the depression of a coast and the consequent landward shifting of the shore line, the later marine sediments cover up the extremities of the older ones, there is said to be an overlap.

Prrch. The inclination of the axis of a fold of rock. 
Post. A mass of slate traversed by so many joints as to be useless. This term is also used to denote bands of hard rock.

PSEUdOMORPh. A mineral that has assumed the crystal form of a different mineral as the result of the partial or entire alteration or replacement of the original mineral through chemical processes.

QUARTzITE. A sandstone in which the grains are held together by a siliceous (quartz) cement.

RIBBon. A line of bedding or a thin bed appearing on the cleavage surface, sometimes of a different color; or a small bed of quartzose or calcareous material either crossing or parallel to the cleavage. When such ribbons are separated by beds of slate too thin to be worked, the ribbons and the small beds are together designated as "ribbon."

ScUlPING. Fracturing the slate along the grain, i. e., across the cleavage in the direction of the dip. SERICITE. A ribbon-like or fibrous form of muscovite or potash mica.

Shear zoNe. Hogback. (See p. 29 and Pl. VII.)

SLANT. Longitudinal joint more or less parallel to cleavage and often slickensided.

SLICK ENSIDES. Surface of bed or joint plane along which the rock has slipped, polishing and grooving the surfaces.

SLIP. Occasional joint crossing the cleavage, but of no great continuity. Slips are not infrequently fault planes.

SLIP CLEAVAGE. Microscopic folding and fracture, accompanied by slippage; quarrymen's "false cleavage." (See p. 24 and Pls. VI, XI, A.)

SPLIT. Slaty cleavage.

Stratum. A bed.

STRATIFICATION, Bedding, in distinction from cleavage.

STRIKe. Direction at right angles to the inclination of a plane cf bedding, cleavage, jointing, etc. STRIK E JOINT. Joint parallel to the strike of the cleavage.

SULPHUR. Iron pyrite.

SYNCLINE. The trough part of a fold of rock.

SYNCLINORIUM. A mountain mass, in general internal structure trough shaped.

THICK JoINT. Two or more parallel joints between which the slate has been broken up or decomposed.

TrLL. A mixture of clay and pebbles deposited by glaciers.

Top. The weathered surface of a slate mass or the shattered upper part of it.

UnCoNFormity. When the lower one of two contiguous deposits affords evidence of having been exposed to atmospheric erosion before the deposition of the upper one, there is said to be an unconformity between them.

VeIN. When correctly used, denotes a more or less irregular, sometimes ramifying, mineral mass, often of quartz, with calcite, etc., within the slate. Such veins are called veins of segregation, to show that they consist of matter collected from the adjacent rock by solvent waters. But, as generally used by slate quarrymen. "vein" is the equivalent of bed or stratum.

WaVers. Annelid trails.

WiLD Rock. Any rock not fit for commercial slate. 



\section{N D E X.}

A.

Albion quarry, Pen Argyl, Pa... Analyses of slates, chemical... 16-18, 34-38, 41-42, $53,57-58,60,71,73-74,88-89,105-108,111$ Analyses of slates, microscopic or mineral . 12,

$14-16,51,53-55,57,63-67,124$

Analysis, microscopic, method of ........ 48-49

Anatase in slate, occurrence of........... 11, 114

Andalusite in slate, occurrence of ....... 11,14,87

Apatite in slate, occurrence of ............ 11

Aqueous sediments, slates derived from.... 5-6

Ardennes, France, slates of, character of...

slates of, cleavage in ..................

minerals in......................

waste in ...

Arizona, slate of, description of ..............

slate deposits of, location of .........51-52 location of, map showing .......... 52,54

slate of, analysis of. character and mineral composition of $53-55,124$ mineral particles in .............. 13-14 production of................. 126-131

Arvonia, Va., slate deposits at.......... 19, 31 , $33,113-115,124-125$

Auld \& Conger, slate quarries of ......... 77,98 Ausweichung clivage. See Slip cleavage.

B.

Bailey, E. H. S., on slate characteristics... 81,124 Bangor, Pa., slate quarries at ........ $75-77,125$ Barite in slate, occurrence of ............. 109 Bate. See Slip cleavage.

Baur, - , on cleavage ................. 24

Becker, G. F., on cleavage ............... 10 on cleavage bands................... 32

Bedding, character of ................. 13-22 erosion of ............................ 9 origin of ......................... 18 relations of cleavage and ........ 22-23,42-43 figures showing .................. 23,43 views of ............................... 18

Bennett Creek Slate Co., slate quarry of... 69-70

Benson, Vt., slate deposits at ............. 110 slate from, analyses of ............... 111 features of .................. $33,110,124$

Bibliography of slate................. 138-145

Biotite in slate, occurrence of............. 11,14

Blissville, Vt., section at ................. 97-98 section at, plate showing......... 20

Blue Mountain quarry, Pa., view of ...... 82
Böttinger, C., on frost action as related to porosity in slates............... 48

Brandon Slate Co., slate deposits of....... 104 Bremo, Va., slate deposits at......... 11,115, 124 Brennan \& MicElwen, slate deposits of..... 53 Brögger, on shear zones .................. 29 Brownville, Me., quarries at ......... 65-67, 124 quarry at, plate showing .............. 66 slate from, thin section of, plate showing ........................ 64

Buckley, E. R., on Arkansas slates........ 52

C.

Calcite in slates, occurrence of ........ 11, 76, 109

California, geologic map of part of........ 56 igneous slate in, analyses of............ 58 roofing slate in, production of ......... 59 slate deposits of ..................... $56-59$ slate of, analyses of ................ $57-58$ characteristics of .............. 57-58, 124 market for..................... 59 production of ................... 126-131 structure of $\ldots \ldots \ldots \ldots \ldots \ldots \ldots \ldots \ldots \ldots+56$ transportation of ................. 59

Cambrian time, crustal movements in ..... 34 slate deposits of ............... 70,93-110 bedding in, plate showing......... 20 shear zones in, plate showing...... 30 Campbell and Donald, on slate characteristics $\quad 47$

Carbon, color of slates due to............. 7 Carbonaceous matter in slate, occurrence of. 11 Carbonate in slate, occurrence of .......... 14 Castleton, vt., slate deposits at............ 21 Cedar Point, Vt., slate deposits at...... 15-16, 21 Chapman, Pa., slate deposits at ....... 80-81,125 Chapman Slate Co., slate quarries of.. $80,122,124$ Chemical analyses. See Analyses.

Chemistry of slates, account of ........... 34-42

Chili Bar Slate Co., slate quarry of ........ 58 Chlorite in slates, occurrence of ..... 11, 12, 14, :03 Classification of slates .................. 5-6 Clay in slates, occurrence of.............. 46

Clay slates, origin of ................. 5,8 See also Slates.

Cleavage, cause of .................... $7-8$ character of ............. 5, 8-9, 18-19, 22-25 curvature of ...................... 24 relation of axes of folds to............. 23 relation of bedding planes to..... 22-23,42-43 figures showing.................. 23,43 surface of, character of ............... 46 
Page.

Cleavage bands, occurrence of.............. 31-32

plate showing ...................... 64

slipping of, figures showing .......... 32

Cocke, C. C., s'ate deposits of .............. 115

Color of slates, causes of ................ 7,39-42 changes in.......................... 46 shades of .......................... 5

Compass, use of, in prospecting............ 44

Coons, A. T., on slate production ........ 125-132 Corrodibility, tests of ................... 48

Credner, G. R., on rutile in slates.......... 13

Crosby, W. O., on Brownville slates........ $\quad 66$

D.

Danville, slate deposits of ................ 52

Daubrée, A., experiments of .............. 8, 85

De la Beche, H. T., on cleavage of slates.... 24

De la Harpe and Reverdin, on porosity of slate.

Density of slate, testing of. relation of joints and shear zones to... 28,44 Discoloration, cause of .............. 15-17, 39-42 effect of, on values................... 46 occurrence of ....................... 6, 12,46

Donald and Campbell, on slate characteristics ....................... 47

E.

East Bangor Consolidated Slate Co., slate quarries of................... 77-78

East Brownville Slate Co., slate of........ 66

East Poultney, Vt., slate deposits near..... 31

Eckel, E. C., on Arkansas slates........... 51-53

on California slates.................. 56-59

on Georgia slates................... 59-60

on Tennessee slates .................. 88-89

on Utah slates..................... 89

Elasticity, character of .................. 47

Empire Red Slate Co., slates of............ 16

England, slates of, analyses of ......... 18,34-35

slates of, cleavage in................. 23

Epidote in slate, occurrence of ............ 11

Eureka quarry, Pa., structure in, figure showing .................... 83

view in .......................... 82

Eureka Slate Co., quarry and slate of..... 56-58

Exports of slate, table showing ......... 133-137

F.

Fair Haven, Vt., shear zone at, plate show-

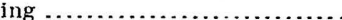

slate quarries near.

slip cleavage at, plate showing

Fair Haven Red Slate Co., slates of ......... slates of, bedding of, plate showing....

False cleavage. See Slip cleavąe.

Faults, occurrence of ......................

Feldspar in slate, occurrence of ............. 11,

Fissility, definition of $\ldots \ldots \ldots \ldots \ldots \ldots \ldots . \quad 25$ occurrence of..................... 5-6 See also Slip cleavage.

Flints, definition of nature and cause of .................. 43-44 occurrence of ....................... 32-33 See also Veins, quartz.

Folds, axes of, relations of cleavage and... 23 efiects of.
Fontaine quarry. See Pitts, A. L.

Page.

Forks, Me., slate deposits at............. $\quad 67$

Fracture, character of ................. 45-46

Fracture cleavage. See Slip cleavage.

France, slates of........................ 6

slates of, analyses of ................... $34-35$

Fresenius, R., on slate ................... 48

Frost, effect of, on slate .................. $\quad 24$

G.

Garnet in slate, occurrence of.............

Geologic map, of Martinsburg, W. Va., district

of western Vermont slate district ..... 88, 100

use of ............................. 44-45

Geology of slates ......................... 34

Georgia, slate of, analyses of.............. 60

slate of, ge(logy of $\ldots \ldots \ldots \ldots \ldots \ldots \ldots .59$ production of ................... 126-131

uses of ............................ 60

Germany, slates of, analyses of ........... $34-35$

Glossary of terms used ................ 146-147

Gorham, Vt., cleavage bands in, figure

showing .............................. 32

Gosselet, J., diagram by................ 23

on folding.......................... 22

on slaty cleavage.................. 22-23

figure explaining ................ 23

Grain, character of ................ 25, 27, 45-46

Granite, slate in proximity to............. 34

Granville, N. Y., slate deposits at... 17, 29, 93, 124

Graphite in slate, occurrence of........... 11

Graptolites, occurrence of............... 95, 99

Guilford, Vt., slate deposits at ............ 89

Gulf Slate Co., slate deposits of ............ 52

Gypsum in slate, occurrence of .......... 11, 76

H.

Hampton, N. Y., slate deposits at ........ 93, 124

Hampton-Janesville, Vt., section through .. $\quad 95$

Hardness of slate, tests for................. 48

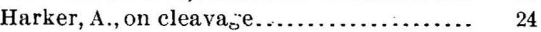

Harris, Abraham, slate prospect of ........ $\quad 70$

Hathenbuck, F. W. C., slate deposits of ..... 89

Hayes, C. W., on Georgia slates ............. 59

Heimbach, Pa., slate quarry at .......... 78,124

Hematite in slates, occurrence of....... 11, 12, 14

Hill, Law rence, slate prospects of ........... 67

Hillebrand, W. F., analyses of slates by .... 15-17,

$36-38,73-74,84,105-108,110$

on chemical composition of roofing

slates ....................... 39-42

Hincum Pond, Vt., plicated joints in slate

at. ........................ 28-29

Hitchcock, C. H., on Maine slates.......... 60

Hogbacks, description of ............... 29-30

Sce also Shear zones.

Hoosick, N. Y., slate quarry at ............ 74

Hornblende in slate, occurrence of.......... 11

Hot Springs, Ark., slate deposits near ...... 52

Hudson grit, slate beds in ......... $71,75,95,98$

Hughes, William, quarry of (Slatington,

$\mathrm{Pa}$.$) , structure in, figure show-$

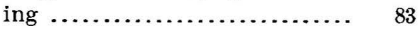

Hutchins, W. M., on slates ............... 13, 49 
Igneous slates, analyses of .................. Page. origin of ........................... 5 Ijamsville, Md., slate deposits at.......... 33, 69 Imports of slate, table of ............... 132-133 Iron, color of slates due to.

\section{$\mathrm{J}$.}

Jackson (Stephen) \& Co., slate quarry of ... $\quad 79$ Jamesville, N. Y., slate quarries at........ 32-33 Jamesville-Hampton, Vt., section through. $\quad 95$ Jannetaz, E., experiments by............. 8, 27 Joints, description of ..................... 27-29 occurrence of ........................ 27-29 relations of dikes, shear zones, and..... 28,44 Joints, curved, occurrence of.............. 28 Joints, plicated, occurrence of............... 28 Jones (Foulk) \& Sons, quarry of, structure in ............................

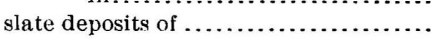

K.

Kansas City Slate Quarrying Co., slate quarry of.

Kaolin in slates, occurrence of ............. Keith, Arthur, on Tennessee slates......... 88 Keyes, C. R., section by ................ 67-68 King, Moses, orbicular granite in quarry of. $\quad 90$ Knots in slate, occurrence of........... 11-12,14

\section{L.}

Lake Bomoseen, Vt., section at............ 97 Lake Bomoseen Slate Co., slate of...... 15-16, 97 Lebanon Springs, N. Y., slate quarry near.. 74 Lehigh Gap, Pa., slates of................ 10 Leith, C. K., on cleavage................. 9-10 Lenses in slate, occurrence of .......... 11-12,14 Lime in slate, occurrence of.............. 46 Limonite in slates, occurrence of ......... 11, 12 Lindgren and Turner, on California slates.. $\quad 56$ Little Missouri Creek, slate deposits of..... 52 Lloyd, E. E., slate quarry of, shear zone in, plate showing.

Lobb, Wm. \& Sons, slate quarry of .a...

Loretz, on slip cleavage ................. 24

Lost Hannah beł, Arkansas, slate from... 54, 124

Lowell Slate Co., slate quarries of......... 65

\section{M.}

McCulloch, Gilbert, analyses by.

Magnesio, color of slate due to...

Magnetite in slate, occurrence of .... 14,27,11, 46 Maine, slate deposits of, description of .... 61-67 slate deposits of, location of........... 60 location of, map showing .......... 61 slate of, characteristics of ........... 123-125 grain in ........................ 34 luster of ........................ 10 prices of ........................ 125 production of ................. 126-131 structure of..................... 27

Mammoth Red Beds, Arkansas, slate from . 54,124 Map of Arkansas slate localities........... 52,54 of Maine slate region................. 61 of Maryland slate region............... 68 of Martinsburg, W. Va., slate region ... 120
Map of New York and Vermont slate belt.. $\quad 88$ of Slatington, Pa., quarries........... 80 of United States, showing location of slate deposits................. 5

of Virginia slate region ............... 112

Map, geologic. See Geologic map.

Marcasite, occurrence of ................. 46

Martinsburg, W. Va., clay-slate deposits near .................6, $6,10,119,124$

clay-slate deposits of, location of, map showing .. ................. 120

Martinsburg shale, slates of ................ 119

Maryland, slate deposits of, description of ........................ 67-70

slate deposits of, location of.......... $67-69$ location of, map showing .......... 68

slate of, characteristics of .............. 6,124 geology of $\ldots \ldots \ldots \ldots \ldots \ldots \ldots \ldots, 6,34$ production of ................. 126-131 veins in ....................... 33 weathering of .................... 34

See also Peach Bottom region.

Massachusetts, slate deposits of, production of ......................... 126-131

Mathews, E. B., on talc in Maryland slate......................... 69

Mathews Consolidated Slate Co., slate quarry of ............... 74, 95, 123

Maw, George, on ribbons in Welsh slate.... 17

Meadow Slate Co., slate quarry of........ 101 Mena, Ark., slate deposits at.......... 53-54, 124 Merrill, G. P., on slate weathering ........ 37 on waste in slate manufacture ........ 42 Merrill-Brownville Slate Co., quarry of, view of $\ldots \ldots \ldots \ldots \ldots \ldots \ldots \ldots .6 .6 \%$

slate quarries of .................6 65-67, 123

Merriman. Mansfield, on slate characteristics ............ 47-49, 73-74, 77, 79, 88 recent tests of slates by $\ldots \ldots \ldots \ldots \ldots . .122-124$ Metamorphism, effects of ................ 7 Mica, formation of ..................... 8

Mica slates, classification of ................ 6

origin of $\ldots \ldots \ldots \ldots \ldots \ldots \ldots \ldots \ldots, 5,7-8$ See also Slates.

Michigan, slate production of ........... 126-131 Middle Granville, vt., section at.......... 95-97 Millstock slate, description of .......... 108-109 Minerals in slate, character and occurrence of ...................... 5-6,11-15

classification of

Minerals in green and púrple Vermont slate, occurrence of .............. 109-110

Mirieral analyses. Sce Analyses.

Minnesota, slate deposits of, bibliography of ........................ 70

slate deposits of, location of ........... 70

slate of, production of ............. 126-131 Monson, Me., slate deposits at...... 10, 61-64,125 Monson Consolidated Slate Co., sla te quarry of .................... $61,64,123$

Monson Maine Sla e Co., slate quarry of ... 61-63 Monson Pond, Me., quarry at, section of... 62 quarry at, slates of .............. $61-63,124$ Montpelier, Vt., slate quarry at .......... 90,93 Mount Ephraim, Md., slate prospect near.. $\quad 70$ Moyer (J. S.) \& Co., quarry of, machinery of, view of................. 78 
Moyer (J. S.) \& Co., quarry of, views of... 78 slate quarries of $\ldots \ldots \ldots \ldots \ldots \ldots \ldots \ldots, 76,78,124$

Müller, F. E., on concretions............. 33

Muscovite in slates, generation of....... 7,13 occurrence of ...................... 12,14

\section{$\mathrm{N}$}

National Red Slate Co., slate of ........ 16, 74, 95 National Slate Co., slate quarry of......... 53 New Jersey, slate deposits of ............ 70 slate of, production of ............. 126-131

New York, slate.deposits of. location of .... 70-71 slate deposits of, location of, map show-

ing. sections across, plate showing ..... characteristics of ........... 71,124-125 composition of............. 39-42,72-74 descriptions of .................. 72-74 faults in ...................... 29 geology of . . . . . . . . . . . . . . . prices of $\ldots \ldots \ldots \ldots \ldots \ldots \ldots \ldots \ldots \ldots . \ldots 125$ production of ................. 126-131 structure of .............. 10, 19, 22, 44

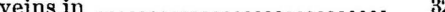

slate quarries in, diagrams of ........ 92, 96

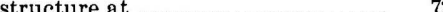

Nodules, occurrence and character of......

North Bangor, Pa., slate quarry at ....... 77

North Bangor Slate Co., slate quarry of .... 77

North Blanchard, Me., slate quarries a ... 65, 124 Northfield, Vt., slate quarries at . ...... 90-93, 124 structure at, figure showing .......... 91

Norton, L. M., analysis by ................ 63

\section{O.}

Old Bangor quarry. See Moyer, J.S., \& Co. Olenellus, occurence of .............. 94,98 Olive grits, occurrence of ............... 98, 100 Ordovician time, crustal movements in.... 34 slate deposits of .......... 71,95-110,119

Ottrelite in slate, occurrence of......... 11

\section{P.}

Paleozoic shales, analyses of ............ $\quad 37$

Pawlet, Vt., section at................. 98-99 section at, plate showing............ 20 shear zone at, plate showing ......... $\quad 30$

Peach Bottom region, $\mathrm{Md}$--Pa., slate deposits of, description of .......... 85-88 slate deposits of, location of.......... 85 slate of, analyses of . ............... 34-35 characteristics of ......... 86-88, 124-125 composition of ................. 12-19 geology of $\ldots \ldots \ldots \ldots \ldots \ldots \ldots \ldots 6,85-\$ 6$ prices of ..................... 125 section of, figure showing ........ 87 waste of ..................... 42 weathering of $\ldots \ldots \ldots \ldots \ldots \ldots \ldots . \quad 37$

Pen Argyl, Pa., slate quarries at... . 78-80, 124-125 weathering at .................... 80

Pennsylvania, geology of slate regions of .. 75-76

Lehigh County, slate deposits of ...... 81-85 slate deposits of, analyses of........ 84

Northampton County, slate deposits of. 76-81 slate deposits of, location of....... 75,85
Pennsylvania, slate of, analyses of . 34-36, 38, 84, 88 slate of, characteristics of ............ 75-76

$84,86-88,122,124-125$

cleavage in ................... 24 composition of ............... 12-13,49 geology of . ........ 6, 10, 34, 75, 81, 85-86 joints in ........................ 28

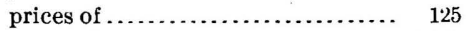
production of ................. 126-131 structure in .................. 19, 75,76 figures showing .............. 82, 83 weathering of ............. 37, 39, 80-81 slate quarries in, map of ............ $\quad 80$ views of $\ldots \ldots \ldots \ldots \ldots \ldots \ldots \ldots \ldots . . \ldots 2,84$ See also Peach Bottom region.

Penrhyn, Wales, slates of ................ 6 Petrography of slates, history of ........ 9-11 minerals in, character of ............. 11-13 sizes of ........................ 13-14

Pfaff, E., on rutile in slates.............. 13 Phillips, John, on cleavage ............ 23-24 Phillips and Sharpe, on slaty cleavage..... 23 Phœnix, Ariz., slates from near.......... 51 Phyllite slates. See Mica slates.

Pigeon slate, character of ............... 88 Pitts, A. L., slate quarry of ...... 113-114, 123-124 Placerville, Cal., slate deposits near ...... 56, 88 slate district of, geologic map of ....... 56 Polarity of slate ...................... 27 Porosity of slate . ................... 47-48 Portland cement, slate waste used in manufacture of ................. 60

Potash-mica. See Muscovite.

Poultney, Vt., shear zone at, plate showing. $\quad 38$ slate deposits' at, bedding of, plate showing .................... 20

Prindle, L. M., on Vermont slates......... 97

Production of slates, statistics of ........ 125-132 Prospecting, suggestions for ............. 44-45 Provident Slate Co., slate quarry of, structure in, figure showing........ 82 Provo, Utah, slate deposits at ........... 89 Purple slate, occurrence and character of . 107-108 Pyrite in slate, occurrence of ......... 11, 109-110 Pyrophyllite in slate, occurrence of...... 14 Pyrrhotite in slate, occurrence of........ 11

Q.

Quarries, slate, technical description of ... $\quad 50$ Quarrying, difficulties of ............... 42 Quartz in slates, occurrence of . ..... 11, 12,14, 109 plate showing quartz veins ........... $\quad 22$

\section{R.}

Raceville, N. Y., slate of ............. 16 Renard, A. F., on petrography of slates.. 11, 12, 27 Reusch, H., on shear zones............. 29 Reverdin and de la Harpe, on slate porosity . $\quad 48$ Rhodochrosite, bed of, analysis of........ 71 Ribbons, occurrence of ............... 19,42 removal of, view of................. 84 Richardson, C. H., on Vermont slates..... 90 Rising \& Nelson slate Co., slate quarry of.. 123 Rockmart formation, slate deposits in..... 59 Rogers, H. D., on structure of slates...... 23, 28 Rogers, W. B., on Virginia slates.......... 111 
Page.

Roofing slates, analyses of . .............. 34-36 composition of . ...................... 39-42 production of ....................... 131

Rosenbusch, H., on slates............. 12-13 on shear zones.................... 29

Roth, Justus, on slates.................. 13

Rupert, Vt., shear zone at, plate showing.. 30 slate deposits at .................... $\quad 31$

Rutile in slates, occurrence of. 11-13

\section{S.}

San Francisco Slate Co., slate quarry of ...

Scales in slates, occurrence of .............

Schists, definition of.

relations of slates and ............... 10-11

Sea-green roofing slate, occurrence and character of ............. 104-106

Sedgwick, Adam, on joints .............. 28 on slip cleavage ................... 24

Sericite in slate, occurrence of .......... 11

Shale, transition of, to mica slate.......... 10,81

Shales, Paleozoic, analyses of ........... 37

Sharpe, Daniel, on cleavage............. 25,27

Sharpe and Phillips, on slaty cleavage.... 23

Shear zones, occurrence of ............. 29, 31 plate showing ................... 30 relations of joints, dikes, and ......... 44

Shenandoah Slate Co., slate quarry of..... 121

Slate Hill, Pa., slate quarry at............ 28

Slate needles, occurrence of . . ............ 13-14

Slate-pencil slaté, description of . . ......... 109

Slates, characteristics of............... 124-125 chemistry of . . . . . . . . . . . . . . . . . . $34-42$

classsification of ................. 6, 125

cleavability of.

See also Cleavage.

compression of.................. 34-37, 39

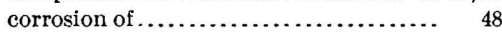

definition of $\ldots \ldots \ldots \ldots \ldots \ldots \ldots \ldots \ldots .5-6,10$

deposits of, location of, map showing.. 5

formation of .................... 7

origin, theory of................. $5-9$

unsettled questions concerning.. 10-11, 13

prices of ............................ 125

strength of, tests showing .......... 47

thin section of, plate showing........ 64

toughness of $\ldots \ldots \ldots \ldots \ldots \ldots \ldots \ldots \ldots . \quad 47$

uses of ...

See also Clay slates; Mica slates; Ash slates; Dike slates; Igneous slates; Roofing slates; Slate-pencil slates; Mill-stock slates.

Slatington, Ark., slate deposits of ........ Slatington, Cal., slate deposits at......... 56

Slatington, Pa., quarries near, structure in - 82-83 ribbon at, removal of, view of......... 84 slate deposits at ............. 75, 81, 124-125 map of ........................ 80 structure in, figures showing....... 82-83 slate of, analyses of ................. 84

Slaty cleavage, definition of .............. 9 plate showing ................... $\quad 26$ production of ...................... 8

Slip cleavage, description of........... 24-25 plate showing ......................... 26 synonyms of .
Snowden, Va, slate deposits at Page. slate quarries at, location of, map showing $\ldots \ldots \ldots \ldots \ldots \ldots \ldots \ldots \ldots . . . \ldots \ldots$

Sonorousness, lack of. ................. $\quad 70$

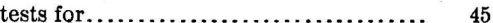

Sorby, H. C., on petrography of slates... 10-11, 13 on slaty cleavage................... 22-23

Southern States Portland Cement Co., slate and cement of................ 60

Southwestern SlateManufacturing Co., slate quarries of $\ldots \ldots \ldots \ldots \ldots \ldots \ldots \ldots 52,55$ slate deposits of .................. 55,124

Specific gravity, determination of ....... 47 Spotted slates, analyses of ............ 15-17 occurrence of . . . . . . . . . . . . . . . . . 15 18 specific gravity of $\ldots . \ldots \ldots \ldots \ldots \ldots \ldots . \quad 47$

Staurolite in slate ................... 11 Steiger, George, analyses by ............ 73-121 Stokes, H. N., analyses by ............... 37 Strain-slip cleavage. See Slip cleavage.

Stratton \& Kelley, slate deposits of ,....... 53 Structure, account of .............. 5, 18-34 views of $\ldots \ldots \ldots \ldots \ldots \ldots \ldots \ldots 18,20,22,26,30$ Sphene in slate, occurrence of........... 11

T.

Talc in slate, occurrence of ............ 11, 69 Tennessee, slate deposits of, description of.. $\quad 88$ slate of, analysis of $\ldots \ldots \ldots \ldots \ldots \ldots \ldots . \quad 88$ production of ................ 126-131

Terms used, glossary of ................ 146-147 Testing, manner of ................... 45-49 Texture, character of ................. $6-8$ Thetford, Vt., slate deposits at............ $\quad 89$ Thürach, H., on slate characteristics....... 13 Thurston, Md., slate quarries near .... 69-70, 124 Tilden, W. C., analysis by ............... 121 Toughness, determination of............ 47 Tourmaline in slates, occurrence of...... 11 Turner, H. W., on shear zones........... 29 Tyndall, John, experiment by ........... 8

\section{U.}

Ulrich, E. O., on age of Arvonia slate forma-

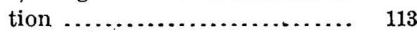

Unfading and seagreen slates, boundary of. 101 Unfading green roofing slate, description of .................... 106-107

Utah, slate of, analysis of ............. 89 production of................ 126-131

\section{V.}

Van Hise, C. R., on cleavage bands....... 32 on slate....................... 9

Variegated slate, description of ........ 107, 108 Veins, quartz, occurrence of ........... 32-33,43 plate showing .................. 22

Vermont, Northfield Township, slate quarries of .................... 90-93 slate deposits of, location of .......... 89-90 slate deposits of, location of, map showing ......................... 88 sections across, descriptions of . .... 94-99 plate showing ............... 90 structure of ................. 101-103 
Page.

Vermont, slate of, analyses of. ..... 36, 105-108,111 slate of, bedding of, plate showing..... 20 characteristics of ............... 123-125 cleavage bands in, figure showing.. $\quad 32$ composition of.. $13,18,39-44,90-93,104-110$ distribution of ................. 100-101 geology of .............. 7, 34, 90,93-95 joints in ..................... 28 minerals associated with........ 109-110 nodules in .................... 33 prices of ...................... 125 production of................ 126-131 spots in ..................... 15-17 structure in .......... 19,21-22, 29, 100-104 plate showing ............... 98 slate quarries in, diagrams of ........ 92,96 western part of, slate deposits of ..... . 93-95, $104-110,124$

slate deposits of, section of ........ 94

Vermont Black Slate Co., slate quarry of . 90,124 slate quarry of, structure in, figure showing ....................

Vermont Unfading Green Slate Co., slate

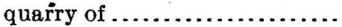

Virginia, slate deposits of, location of..... slate deposits of, location of, map showing ....................112, 116, 117

slate of, characteristics of . . . . . . . . 123-125

composition of $\ldots \ldots \ldots \ldots \ldots \ldots . .11,113-119$

geology of . ............... 34, 111-113

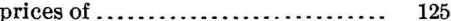

production of . . . . . . . . . 126. . . 131

structure of $\ldots \ldots \ldots \ldots \ldots \ldots \ldots \ldots . . . \ldots . \ldots$

waste of ..................... 37

Virginia Slate Mining Co., slate property of 115-117

W.

Wales, slates of.................... 6,23 slates of, analyses of
Walcott, Charles D., graptolites found by 95,99

Warrenton, Va., slate prospects near.... 117-119

Waterford, Vt., slate deposits at .......... 89

Watrin, N., on petrography of slate...... 27

on slate characteristics............. 47

on waste........................ 42

Weathering, chemical changes in....... 37-39

Wells, Vt., section at ................... 98 shear zone at, plate showing......... 30

West Castleton, Vt., slate quarries at...... 19, 21 slate quarries at, bedding of, plate showing ........................ 20

West Monson, Me., slate quarry at...... 64, 124

West Pawlet, Vt., section at............ 99 slate structure at . . . . . . . . . . . . 19,44, 98 slip cleavage at, plate showing........ $\quad 26$ West Virginia, slate deposits of, location of .......................... 119 slate deposits of, location of, map showing ......................... 120 slate of, characteristics of ............ 124 composition of ............... 10,121-122 geology of $\ldots \ldots \ldots \ldots \ldots \ldots \ldots \ldots \ldots, 119$ weathering of $\ldots \ldots \ldots \ldots \ldots \ldots \ldots .37,122$

Wilhite slate, slate of ................. 88 Wilkinson, -, on slate characteristics..... $\quad 47$ Williams, George H., on Virginia slates... 114 Williams, J. F., on slate characteristics.. $47,73,124$. Williams and Edwards, slate quarry of, shear zone in ............... 30 Williams Brothers, slate quarry of ...... 115, 116 Williams (John R.) Slate Co., slate quarry of ................... 113, 123-121

Z.

Zircon in slate, occurrence of ........... 11 Zirkel, F., on slip cleavage............. 24 


\title{
CLASSIFICATION OF THE PUBLICATIONS OF THE UNITED STATES GEOLOGICAL SURVEY.
}

\author{
[Bulletin No. 275.]
}

The serial publications of the United States Geological Survey consist of (1) Annual Reports, (2) Monographs, (3) Professional Papers, (4) Bulletins, (5) Mineral Resources, (6) Water-Supply and Irrigation Papers, (7) Topographic Atlas of United States-folios and separate sheets thereof, (8) Geologic Atlas of the United States-folios thereof. The classes numbered 2, 7, and 8 are sold at cost of publication; the others are distributed free. A circular giving complete lists may be had on application.

Most of the above publications may be obtained or consulted in the following ways:

1. A limited number are delivered to the Director of the Survey, from whom they may be obtained, free of charge (except classes 2, 7, and 8), on application.

2. A certain number are delivered to Senators and Representatives in Congress, for distribution.

3. Other copies are deposited with the Superintendent of Documents, Washington, D. C., from whom they may be had at practically cost.

4. Copies of all Government publications are furnished to the principal public libraries in the large cities throughout the United States, where they may be consulted by those interested.

The Professional Papers, Bulletins, and Water-Supply Papers treat of a variety of subjects, and the total number issued is large. They have therefore been classified into the following series: A, Economic geology; B, Descriptive geology; C, Systematic geology and paleontology; D, Petrography and mineralogy; E, Chemistry and physics; F, Geography; G, Miscellaneous; H, Forestry; I, Irrigation; J, Water storage; K, Pumping water; L, Quality of water; M, General hydrographic investigations; N, Water power; O, Underground waters; P, Hydrographic progress reports. This paper is the sixty-third in Series A, the complete list of which follows ( $\mathrm{PP}=$ Professional Paper; $\mathrm{B}=$ Bulletin; $\mathrm{WS}=$ Water-Supply Paper):

\section{SERIES A, ECONOMIC GEOLOGY.}

B 21. Lignites of Great Sioux Reservation: Report on region between Grand and Moreau rivers, Dakota, by Bailey Willis. 1885 . $16 \mathrm{pp} ., 5 \mathrm{pls}$. (Out of stock.)

B 46. Nature and origin of deposits of phosphate of lime, by R. A. F. Penrose, jr., with introduction by N. S. Shaler. $1888.143 \mathrm{pp.}$ (Out of stock.)

B 65. Stratigraphy of the bituminous coal field of Pennsylvania, Ohio, and West Virginia, by I. C. White. 1891. $212 \mathrm{pp} ., 11 \mathrm{pls}$. (Out of stock.)

B 111. Geology of Big Stone Gap coal field of Virginia and Kentucky, by M. R. Campbell. 1893. 106 pp., 6 pls. (Out of stock.)

B 132. The disseminated lead ores of southeastern Missouri, by Arthur Winslow. 1896. 31 pp. (Out of stock.)

B 138. Artesian-well prospects in Atlantic Coastal Plain region, by N. H. Darton. 1896. 228 pp., 19 pls.

B 139. Geology of Castle Mountain mining district, Montana, by W. H. Weed and L. V. Pirsson. 1896. 164 pp., 17 pls.

B 143. Bibliography of clays and the ceramic arts, by J. C. Branner. $1896.114 \mathrm{pp}$

B 164. Reconnaissance on the Rio Grande coal fields of Texas, by $\mathrm{T}$. W. Vaughan, including a report on igneous rocks from the San Carlos coal field, by E. C. E. Lord. 1900.100 pp., 11 pls. (Out of stock.)

B 178. El Paso tin deposits, by W. H. Weed. 1901. 15 pp., 1 pl.

B 180. Occurrence and distribution of corundum in United States, by J. H. Pratt. 1901. 98 pp., 14 pls. (Out of stock; see No.269.) 
B 182. A report on the economic geology of the Silverton quadrangle, Colorado, by F. L. Ransome. 1901. $266 \mathrm{pp} ., 16 \mathrm{pls}$. (Out of stock.)

B 184. Oil and gas fields of the western interior and northern Texas Coal Measures and of the Upper Cretaceous and Tertiary of the western Gulf coast, by G. I. Adams. 1901.64 pp., 10 pls. (Out of stock.)

B 193. The geological relations and distribution of platinum and associated metals, by J. F. Kemp. 1902. 95 pp., 6 pls.

B 198. The Berea grit oil sand in the Cadiz quadrangle, Ohio, by W. T. Griswold. $1902.43 \mathrm{pp} ., 1 \mathrm{pl}$. (Out of stock.)

PP 1. Preliminary report on the Ketchikan mining district, Alaska, with an introductory sketch of the geology of southeastern Alaska, by A. H. Brooks. 1902.120 pp., 2 pls.

B 200. Reconnaissance of the borax deposits of Death Valley and Mohave Desert, by M. R. Campbell. 1902. 23 pp., 1 pl. (Out of stock.)

B 202. Tests for gold and silver in shales from western Kansas, by Waldemar Lindgren. $1902.21 \mathrm{pp}$. (Out of stock.)

PY 2. Reconnaissance of the northwestern portion of Seward Peninsula, Alaska, by A. J. Collier. 1902. 70 pp., 11 pls.

PP 10. Reconnaissance from Fort Hamlin to Kotzebue Sound, Alaska, by way of Dall, Kanuti, Allen, and Kowak rivers, by W. C. Mendenhall. 1902. 68 pp., 10 pls.

PP 11. Clays of the United States east of the Mississippi River, by Heinrich Ries. 1903.298 pp., 9 pls.

PP 12. Geology of the Globe copper district, Arizona, by F. L. Ransome. 1903.168 pp., 27 pls.

B 212. Oil fields of the Texas-Louisiana Gulf Coastal Plain, by C. W. Hayes and William Kennedy. 1903. 174 pp., 11 pls. (Out of stock.)

B 213. Contributions to economic geology, 1902; S. F. Emmons and C. W. Hayes, geologists in charge. 1903. $449 \mathrm{pp}$. (Out of stock.)

PP 15. The mineral resources of the Mount Wrangell district, Alaska, by W. C. Mendenhall and F. C. Schrader. $1903.71 \mathrm{pp} ., 10 \mathrm{pls}$

B 218. Coal resources of the Yukon, Alaska, by A. J. Collier. 1903.71 pp., 6 pls.

B 219. The ore deposits of Tonopah, Nevada (preliminary report), by J. E. Spurr. 1903.31 pp., 1 pl. (Out of stock.)

PP 20. A reconnaissance in northern Alaska in 1901, by F. C. Schrader. 1904.139 pp., 16 pls.

PP 21. Geology and ore deposits of the Bisbee quadrangle, Arizona, by F. L. Ransome. 1904. 168 pp., 29 pls.

B 223. Gypsum depósits in the United States, by G. I. Adams and others. 1904.129 pp., 21 pls.

PP 24. Zinc and lead deposits of northern Arkansas, by G. I. Adams. 1904.118 pp., 27 pls.

PP 25. Copper deposits of the Encampment district, Wyoming, by A. C. Spencer. 1904.107 pp., 2 pls.

B 225. Contributions to economic geology, 1903, by S. F. Emmons and C. W. Hayes, geologists in charge. 1904. $527 \mathrm{pp} ., 1 \mathrm{pl}$. (Out of stock.)

PP 26. Economic resources of the northern Black Hills, by J. D. Irving, with contributions by S. F. Emmons and T. A. Jaggar, jr. 1904. 222 pp., 20 pls.

PP 27. A geological reconnaissance across the Bitterroot Range and Clearwater Mountains in Montana and Idaho, by Waldemar Lindgren. 1904.123 pp., $15 \mathrm{pls}$.

B 229. Tin deposits of the York region, Alaska, by A. J. Collier. 1904. 61 pp., 7 pls.

B 236. The Porcupine placer district, Alaska, by C. W. Wright. 1904.35 pp., 10 pls.

B 238. Economic geology of the Iola quadrangle, Kansas, by G. I. Adams, Erasmus Haworth, and W. R. Crane. 1904. 83 pp., 11 pls.

B 243. Cement materials and industry of the United States, by E. C. Eckel. 1905.395 pp., 15 pls.

B 246. Zinc and lead deposits of northwestern Illinois, by H. Foster Bain. 1904. 56 pp., 5 pls.

B 247. The Fairhaven gold placers Seward Peninsula, Alaska, by F. H: Moffit. 1905.85 pp., 14 pls.

B 249. Limestones of southeastern Pennsylvania, by F. G. Clapp. 1905. 52 pp., 7 pls.

B 250. The petroleum fields of the Pacific coast of Alaska, with an account of the Bering River coal deposits, by G. C. Martin. 1905 . 65 pp., 7 pls.

B 251. The gold placers of the Fortymile, Birch Creek, and Fairbanks regions, Alaska, by L. M. Prindle. 1905. $89 \mathrm{pp} ., 16 \mathrm{pls}$.

WS 117. The lignite of North Dakota and its relation to irrigation, by F. A. Wilder. $1905.59 \mathrm{pp} ., 8 \mathrm{pls}$.

PP 36. The lead, zinc, and fluorspar deposits of western Kentucky, by E. O. Ulrich and W. S. T. Smith. 1905. 218 pp., 15 pls.

PP 38. Economic geology of the Bingham mining district, Utah, by J. M. Boutwell, with a chapter on areal geology, by Arthur Keith, and an introduction on general geology, by S. F. Emmons. 1905. $413 \mathrm{pp} ., 49 \mathrm{pls}$.

PP 41. Geology of the central Copper River region, Alaska, by W. C. Mendenhall. 1905. 133 pp., 20 pls.

B 254. Report of progress in the geological resurvey of the Cripple Creep district, Colorado, by Waldemar Lindgren and F. L. Ransome. $1904.36 \mathrm{pp}$.

B 255. The fluorspar deposits of southern Illinois, by H. Foster Bain. 1905.75 pp., 6 pls.

B 256. Mineral resources of the Elders Ridge quadrangle, Pennsylvania, by R. W. Stone. 1905. 86 pp., 12 pls.

B 259. Report on progress of investigations of mineral resources of Alaska in 1904, by A. H. Brooks and others. $1905.196 \mathrm{pp} ., 3 \mathrm{pls}$. 
B 260. Contributions to economic geology, 1904; S. F. Emmons and C. W. Hayes, geologists in charge. 1905. 620 pp., 4 pls.

B 261. Preliminary re ort on the operations of the coal-testing plant of the United States Geological Survey at the Louisiana Purchase Exposition, St. Louis, Mo., 1904; E. W. Parker, J. A. Holmes, and M. R. Campbell, comm 'ttee in charge. 1905. $172 \mathrm{pp.} \mathrm{(Out} \mathrm{of} \mathrm{stock.)}$

B 263. Methods and cost of gravel and placer mining in Alaska, by C. W. Purington. 1905. 273 pp., $42 \mathrm{pls}$.

PP 42. Geology of the Tonopah mining district, Nevada, by J. E. Spurr. 1905.295 pp., 24 pls.

PP 43. The copper deposits of the Clifton-Morenci district, Arizona, by Waldemar Lindgren. 1905. 375 pp., 25 pls.

B 264. Record of deep-well drilling for 1904, by M. L. Fuller, E. F. Lines, and A. C. Veatch. 1905. $106 \mathrm{pp}$.

B 265. Geology of the Boulder district, Colorado, by N. M. Fenneman. 1905.101 pp., 5 pls.

B 267. The copper deposits of Missouri, by H. Foster Bain and E. O. Ulrich. 1905.52 pp., 1 pl.

B 269. Corundum and its occurrence and distribution in the United States (a revised and enlarged edition of Bulletin No. 180), by J. H. Pratt. 1906. 175 pp., 18 pls.

PP 48. Report on the operations of the coal-testing plant of the United States Geological Survey at the Louisiana Purchase Exposition, St. Louis, Mo., 1904; E. W. Parker, J. A. Holmes, M. R. Campbell, committee in charge. 1906. (In 3 parts.) $1492 \mathrm{pp} ., 13 \mathrm{pls}$.

B 275. Slate deposits and slate industry of the United States, by T. N. Dale, with sections by E. C. Eckel, W. F. Hillebrand, and A. T. Coons. 1906. 154 pp., 25 pls.

Correspondence should be addressed to

The Director,

United States Geological Survey,

JUNE, 1906.

Washington, D. C.

() 



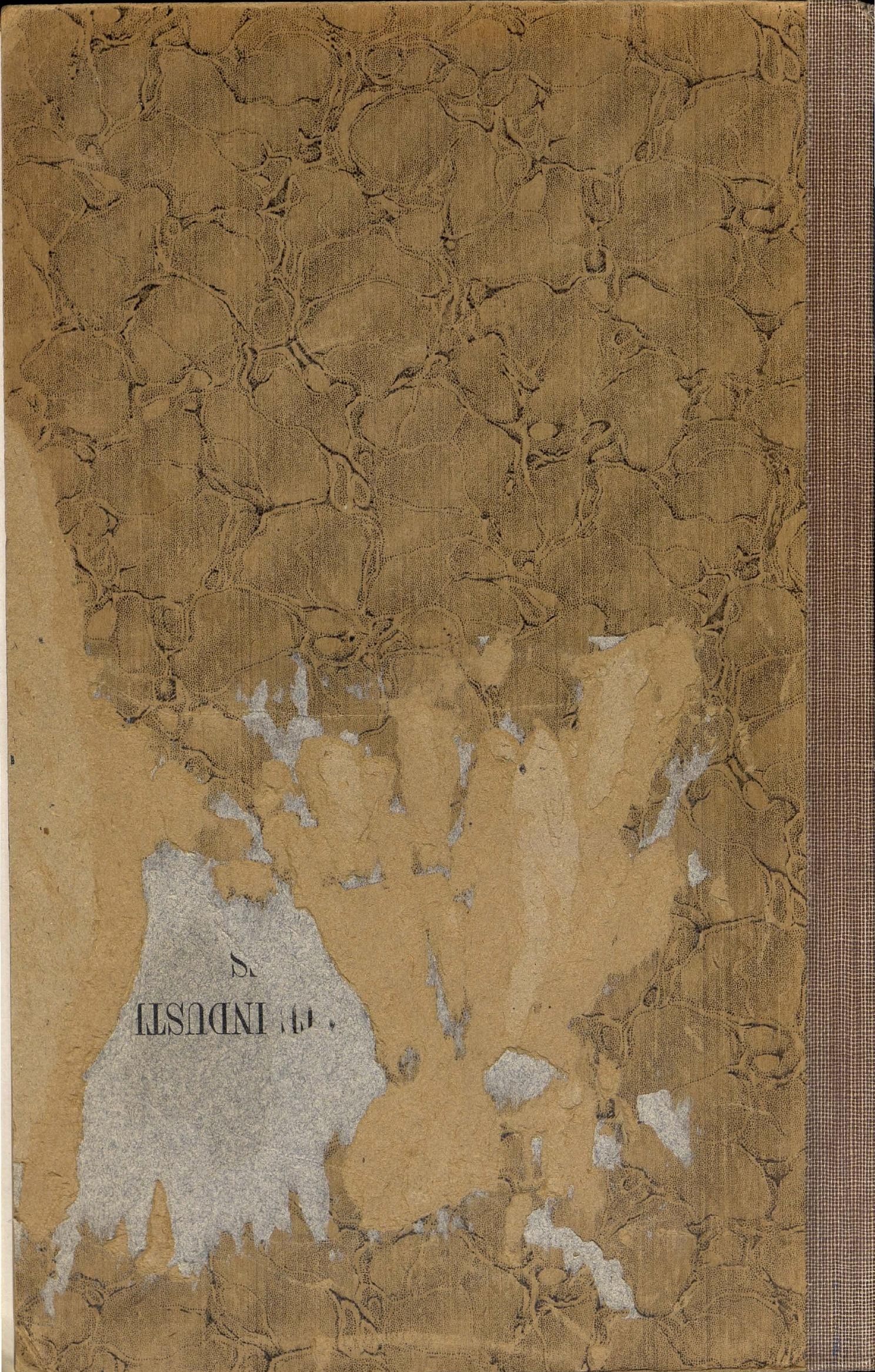

